\title{
LA SEPARACIÓN DE PODERES EN EL CONSTITUCIONALISMO BURGUÉS
}

\author{
Juan Manuel Olarieta Alberdi \\ EMUI_UCM - Colegio de Abogados de Madrid
}

\section{SUMARIO}

1.Introducción | 2. La separación entre el Estado y la sociedad | 3. Tipología de las constituciones de la época revolucionaria | 4. La supremacía del poder legislativo y sus límites | 5. Las tres racionalidades de la separación de poderes | 5.1 Formas de distribución de competencias (La racionalidad técnica) | 5.2 Libertades públicas y libertades privadas (La inexistencia de racionalidad axiológica en la separación de poderes) | 5.3 El derecho de resistencia | 5.4 Gobierno mixto: separación de poderes y separación de clases sociales (La racionalidad política) | 6. La unidad del poder ejecutivo y su monopolio de la fuerza | $6.1 \mathrm{La}$ supuesta limitación o autolimitación del poder del Estado | 6.2 El rey como poder ejecutivo | 6.3 La reducción al mínimo de la actividad ejecutiva y su fragmentación $\mid 7$. El sistema judicial constitucional | 7.1 La funcionalidad constitucional de los jueces | 7.2 La organización del sistema judicial | 7.2.1 La experiencia judicial inglesa | 7.2.2 El debate en la Asamblea constituyente francesa | 7.3 La reducción de las competencias judiciales al ámbito privado | 7.4 La supuesta mediación jurisdiccional entre los demás poderes del Estado | 7.5 Lo público y lo privado en la independencia del poder judicial | 7.6 El supuesto papel de los jueces como garantes de los derechos y libertades fundamentales | 7.7 Breve excurso: la libertad de imprenta como prototipo | 8. Evolución posterior de la separación de poderes | Notas

En el parlamento, la nación elevaba su voluntad general a la ley, es decir, elevaba la ley de la clase dominante a su voluntad general. Ante el poder ejecutivo, abdica de toda voluntad propia y se somete a los dictados de un poder extraño, de la autoridad. El poder ejecutivo, por oposición al legislativo, expresa la heteronomía de la nación, por oposición a su autonomía

\section{Carlos Marx, El 18 Brumario de Luis Bonaparte, 1852}

Parécense los hombres del año 12, amigo Andrés, al cura que no sabía leer más que en su breviario, o mejor, al gastrónomo en Vista Alegre, que viendo su mesa puesta, pugna por sentarse a ella en cuanto le dejan un momento libre, en cuanto ve un resquicio por donde acercarse a la mesa. El caso es el mismo: todos les hacemos cumplimientos, pero no les dejamos sentarse. Unas veces se lo impidió don Pascual de la Rivera, otras los mozos de su fábrica.. Convengo en que es una desesperación; pero culpen, no a nosotros, sino a ellos mismos, que tantas veces se dejaron interrumpir antes de llegar el bocado a la boca.

\section{Mariano José de Larra}




\section{Introducción}

Los cambios histórico-políticos operados después de doscientos años de constitucionalismo han sido muy sustanciales pero, sin embargo, a la hora de hacer referencia a la revolución burguesa, en la literatura jurídica corriente (1) hay muy poco manejo de las fuentes originales y un exceso de recurso a los clásicos de la teoría del Estado de finales del pasado siglo y comienzos del presente, cuya visión del fenómeno estaba mediatizada y condicionada por dos factores esenciales: su propia realidad política, muy distinta de la época de la revolución burguesa, y la interposición del doctrinarismo, que en este punto ha causado estragos, al introducir claves ideológicas justificativas del dominio político burgués.

Completamente fuera de su microclima, la separación de poderes ha dejado ya de ser un principio jurídico-constitucional preciso para convertirse en una leyenda, en un mito (2) en el que es difícil discernir lo que es realidad histórica, de lo que es mera fantasía. Circula por los circuitos actuales de las ideas jurídicas con vida propia y virtualidad suficiente para explicar el surgimiento de cualquier clase de institución o principio al que se necesite justificar y dotar de un determinado contenido. No hay escarceo erudito que no se remonte, como mínimo, hasta la separación de poderes para contrastar una y otra época al gusto de cada cual.

Destaca sobre todo, el olvido en que hoy se encuentra el "derecho" de resistencia, que constituye una de las piezas esenciales del pensamiento liberal de la época revolucionaria, hasta el punto que resulta imposible -según creotener una comprensión cabal del entramado político-jurídico del primer constitucionalismo burgués sin tener en cuenta este "derecho". Y es fácil caer en la cuenta del interés subyacente en tamaño olvido.

Hoy la doctrina jurídica propende a minusvalorar la separación de poderes; así, para Adolfo Posada se ha dado un "valor excesivo" a esta materia (3), que según, entre otros, Jellinek (4) y Loewenstein, se reduce a una mera formalidad técnico jurídica (5). En mi opinión, por contra, la separación de poderes es el acto inaugural del Estado liberal, su pieza maestra: "Toda la ideología liberal, con sus puntos fuertes y sus puntos débiles -escribió Gramsci- se puede resumir en el principio de la división de los poderes" (6).

En la comprensión del principio se han interpuesto dos obstáculos que impiden el acceso al objeto que se trata de analizar: el obstáculo del lenguaje y el obstáculo jurídico. Obstáculo del lenguaje porque continuamos empleando los mismos conceptos jurídicos acuñados entonces, de manera que hablamos de realidades distintas bajo las mismas expresiones; y porque, en otras ocasiones, nos referimos a aquella época con conceptos elaborados posteriormente.

El propio Montesquieu acuña una nueva expresión, como "exécutif" que la Academia de la Lengua francesa no admite hasta 1835, y utiliza ambivalentemente los términos "pouvoirs" y "puissances", dándoles un significado del que antes carecían (7). Esta renovación linguística denota que 
hay un interés evidente por definir y delimitar con claridad el principio, impidiendo confusiones con posibles precedentes; que Montesquieu era consciente de que se trataba de algo totalmente distinto que él trata de precisar y deslindar con nuevas expresiones para evitar ambigüedades, en particular nos parece- con las doctrinas relativas al llamado gobierno mixto. El esfuerzo de innovación linguística de Montesquieu no tuvo ninguna fortuna, y ha sido, en buena parte, la razón determinante de muchas de las confusiones que envuelven su teoría política.

El obstáculo jurídico deriva de que la separación de poderes no es sólo ni principalmente un principio jurídico, sino más que nada la articulación formal de una cuestión política subyacente. Hay que partir de que sociológicamente el poder del Estado:

- no es siempre monopolístico, sino que depende de instancias superiores (caso de los países coloniales, por ejemplo), o coexiste con otros poderes confluyentes (Iglesia en los siglos anteriores, grupos de presión en la actualidad) u opuestos (guerra civil y sitaciones de dualidad de poderes en general)

- no se distribuye nunca enteramente entre los poderes constituídos, sino que, por el contrario (8), queda algo al margen (poderes fácticos, secretos o extralegales) bien dentro del Estado mismo o bien en la sociedad ("derecho" de resistencia)

- no se distribuye uniformemente entre los tres poderes constituídos, sino que ese reparto es desigual (9) beneficiando al legislativo (postura clásica) o al ejecutivo (tesis de Maurice Hauriou), siendo reseñable que nadie, ni siquera en la órbita anglosajona (10), defienda la primacía del judicial; pero entendido sociológicamente, es correcta la tesis de Maurice Hauriou: no hay más poder que el ejecutivo.

Las normas jurídicas no evidencian, ni explican, en ocasiones, la correlación y el juego de fuerzas políticas, sino que las enmascaran y ocultan. Por ello, sería preferible utilizar la vieja terminología de la Constitución gaditana, que deliberadamente hablaba, por ejemplo, de "potestad jurisdiccional" (11), anticipándose con mucho a la distinción que establecieran Carnelutti y Santi Romano (12) entre poder y potestad: el primero denota una situación de supremacía "de facto" (13); Duguit, entre otros autores (14), lo han definido como el monopolio de la violencia por el Estado. En cuanto a la segunda, requiere no solamente un cierto poder de hecho, unas atribuciones específicas, sino además que su titular este revestido de autoridad jurídica, de legalidad (15).

Esta diferenciación es importante porque no siempre hay correspondencia entre ambos órdenes: no siempre los poderes jurídicos, los poderes reconocidos como tales por el Derecho, disponen efectivamente de atribuciones reales. La distinción entre "potencia aparente" y "potencia real" aparece en Rousseau (16), volvió a insistir sobre ella Lassalle (17), y Jellinek habló de "poder de dominación" y "poderes no dominantes"(18). Puede decirse que existen "poderes jurídicos", meramente formales, que únicamente lo son por estar reconocidos como tales por el Derecho, y "poderes reales" o 
efectivos, que son aquellos que disponen de fuerza y capacidad de coacción (19). De las "cartas" constitucionales de comienzos del siglo XIX, se desprende que sólo el rey es una "potencia", afirma Lanjuinais; los demás "establecimientos públicos" no son más que meros "poderes", que define como "autoridades de derecho desprovistas legalmente de fuerza física" (20). La dicotomía se aprecia también en el modo de actuación de cada uno de los poderes: unos se limitan a emitir declaraciones o enunciados, mientras que los otros actuan y se mueven en la realidad (21). "La unión de lo fáctico y lo jurídico -decía Schmitt- es el problema cardinal del concepto de soberanía" (22). También Flórez Estrada (23) y Jellinek (24) diferenciaron entre soberanía de hecho y de derecho. La distinción permite el pasaje del lenguaje jurídico al político, y viciversa (25); permite delimitar, en definitiva, el ámbito del hecho respecto al del Derecho.

La confusión deriva -amén de intereses ideológicos- del empleo de cuatro acepciones distintas del término "poder" que también aquí utilizaremos, porque todas ellas concurren en la separación de poderes. Poder, en el ámbito jurídico-privado, es mandato más representación, gestión de negocios ajenos, fideicomiso y similares, de aplicación también en el Derecho público liberal, a diferencia del anterior. Es también un binomio compuesto de competencia, habilitación o capacidad de obrar de un órgano determinado, es decir, tiene un aspecto objetivo o funcional (las facultades asumidas) y otro subjetivo, su titularidad jurídica, la imputación del actuar a una determinada institución o persona; poder es, desde este aspecto, la unión de competencia y órgano. En tercer lugar, el poder, en su sentido más llano, es fuerza, coacción, violencia, intimidación, etc., esto es, capacidad para imponerse sobre la voluntad de otro, lo que singulariza al Derecho público sobre el privado, donde impera el principio de la autonomía de la voluntad. Y finalmente, concurre también en el poder público, y precisamente por ese carácter, la noción de supremacía, de "imperium", que es la consecuencia de la separación entre el Estado y la sociedad, la superioridad y capacidad de obligar del primero sobre los particulares.

\section{La separación entre el Estado y la sociedad}

La separación de poderes constituyó un aspecto de la separación fundamental del liberalismo: la verificada entre el Estado y la sociedad, entre lo público y lo privado (26), de origen romanista, que aunque ya se apuntaba bajo el absolutismo (27), es la pieza básica que permite comenzar la edificación del Estado burgués, por arriba, y el despliegue del capitalismo por debajo. Se trataba de asegurar el libre desenvolvimiento de la iniciativa individual, el mercado y la concurrencia mercantil (28). Para ello había que separar el ámbito privado y patrimonial (29) de las injerencias públicas y administrativas, impedir el intervencionismo estatal, lo que da lugar a la prohibición de las confiscaciones (art.304 de la Constitución de Cádiz) que, en expresión de Voltaire, son sinónimo de "tiranía" (30).

No hay Estado liberal sin previo deslinde de la sociedad, para lo que la revolución tuvo que: 
- destruir los estamentos intermedios, las corporaciones privadas que venían asumiendo funciones públicas (31)

- delimitar el Estado respecto de la familia, el poder público de la patria potestad (32)

- diferenciar el patrimonio nacional del privado de la corona: "La Nación española es libre e independiente, y no es ni puede ser patrimonio de ninguna familia ni persona”, dice el art.2 de la Constitución de Cádiz (33)

- reconducir la religión al ámbito de la conciencia, al ámbito privado, frente a construcciones de Derecho público como el "Sacro Imperio" (34).

El Estado constitucional liberal no tiene nada que ver con las anteriores superestructuras políticas, y en sus relaciones con la sociedad se caracterizará por su "neutralidad": abstencionismo económico, aconfesionalidad religiosa y neutralidad política (35). En réplica a las diversas teorías precedentes sobre cuáles habían de ser los fines del Estado, el liberalismo responde que el Estado carece de fines (36), que es meramente pasivo, que los fines están en los particulares, en el mundo privado (37). Fue Rousseau quien remarcó con énfasis este aspecto, lo que le lleva a dar un paso más que sus predecesores, distinguiendo no solamente al Estado del rey, sino también -por vez primera- al Estado del gobierno: éste, en cuanto poder ejecutivo, podía ser activo; pero el Estado es esencialmente pasivo respecto a la sociedad (38). El único objeto de la actividad pública es preservar la separación entre el Estado y la sociedad: es en esta última donde se proponen los fines y las iniciativas, que el Estado debe proteger tutelar y defender pero sin intervenir. "De todos los medios de alcanzar la felicidad- sentenció Sieyes- el Estado es el más poderoso" (39). Aunque la separación de poderes no es mero artificio técnico, sí resulta cierto que el Estado burgués originario pretende ser "neutral" y pasivo, una maquinaria inerte movida a impulsos de la sociedad civil (40) que contrasta con el carácter "misional" de los reinos medievales (41).

Ahora bien, la separación entre el Estado y la sociedad no da cuenta cabal del complejo de relaciones entre ambos según fue perfilado por el pensamiento liberal revolucionario: están separados sí, pero con el carácter de supremacía o "imperium" de lo público respecto de lo privado. Locke lo explica en las primeras páginas de su Ensayo: mientras el estado de naturaleza se caracteriza por su igualitarismo, "sin subordinación ni sometimiento"(42), el estado civil impone diferenciaciones, superioridades, dotando a unas personas de "poder de mando" respecto a las demás. La supremacía de la autoridad pública supone tanto capacidad de mando, por parte del poder público, como deber de obediencia por parte de los ciudadanos (arts.7, 288 y 289 de la Constitución de Cádiz). El deber de obediencia es algo sustancialmente distinto de la fidelidad feudal, del vasallaje. El art.7 de la Constitución española diferencia esta obligación de obedecer a la ley, de la obligación de los funcionarios públicos (art.373) en general, y de los jueces y magistrados en especial (art.279), de ser fieles al rey; en un caso hay una sujeción a un mandato general y abstracto, mientras que en otro hay un servilismo hacia la persona que anula la voluntad individual (43). Hobbes definió la ley como "la palabra de quien por derecho tiene mando sobre los demás" (44), y Rousseau dirá que la obediencia a la ley es libertad, de modo que "quien rehúse obedecer 
a la voluntad general será obligado a ello por el cuerpo" (45). Es conocida la expresión de la Constitución de 1791: "No hay en Francia autoridad superior a la ley. El rey no reina sino por ella y sólo en nombre de la ley puede exigir obediencia". La facultad de ordenar, por parte de la autoridad, supone el dominio de la fuerza y de los medios capaces de imponer la obligación a los ciudadanos; y por parte de estos, equivale a reducir el "derecho" de resistencia a los casos de discordancia de los mandatos con el Derecho natural, de la norma positiva con el criterio de legitimidad expuesto en las declaraciones de "derechos", por una parte, y por la otra con el propósito de utilidad pública -y no particular- que debe guiar toda la actividad del Estado.

Separación y superioridad son los dos rasgos que caracterizan las relaciones entre el Estado burgués y la sociedad. El ciudadano tiene esas dos vertientes contradictorias, según Rousseau: es al tiempo soberano y súbdito. No obstante, esa separación y esa superioridad no son más que aparentes: superioridad no significa, como puede parecer, que los intereses públicos se situen por encima de los privados, sino todo lo contrario. El Estado constitucional "neutro" no tiene intereses propios distintos de los que bullen en el interior de la sociedad civil: su "neutralidad" sólo significa que la dirección, el rumbo y el funcionamiento del Estado está en manos y al servicio de los fines que la nación le indique. Cualquier determinación teleológica es de carácter privado, se desenvuelve dentro del ámbito del mercado.

No es difícil deducir, desde esta perspectiva, que no puede existir una superioridad del interés público sobre el privado, sino todo lo contrario: el interés público no es más que el mantenimiento de su separación respecto de lo privado, su servilismo respecto a éste. El gobierno -sostiene Rousseau- no se ha establecido más que para asegurar la propiedad particular, que es anterior a él (46). "La seguridad -decía el art.8 de la Declaración jacobinaconsiste en la protección otorgada por la sociedad a cada uno de sus miembros para la conservación de su persona, de sus derechos y de sus propiedades". Y con más claridad aún se expresó el art.23 de esta misma Declaración: "La garantía social consiste en la acción de todos para asegurar a cada uno el goce y la conservación de sus derechos; esta garantía reposa en la soberanía nacional". El art.5 del proyecto constitucional español decía: "La Nación está obligada a proteger y conservar a sus individuos todos sus derechos" (47). Y el art.4 del texto constitucional definitivo sentenció: "La Nación está obligada a conservar y proteger por leyes sabias y justas la libertad civil, la propiedad y los demás derechos legítimos de todos los individuos que la componen". Por su parte, el art.13 remarcaba: "El objeto del gobierno es la felicidad de la Nación, puesto que el fin de toda sociedad política no es otro que el bienestar de los individuos que la componen". El Estado asegura el orden público para que los intereses domésticos circulen y se desenvuelvan libremente: los asegura, protege y tutela sin afectarlos. La supremacía de lo público no es pues subordinación de lo privado: lo público está por encima precisamente porque está al servicio de lo privado. Aquí el matiz es decisivo. No hay mejor forma de beneficiar a unos intereses privados que desde un ámbito público calificado de superior y "neutral" a la vez.

Es la gran ventaja de esta configuración del Estado con respecto a otras superestructuras clasistas: "La burguesía propietaria -escribe Alejandro Nieto- a 
diferencia de la aristocracia feudal, no contaba con medios propios de autodefensa y tenía que recurrir al Estado para que, por medio de los jueces y policías, defendiese sus intereses particulares" >(48). La única fuerza de la burguesía estaba en la sociedad, en su control sobre los medios de producción, mientras que la presencia de la nobleza "de robe" en el viejo aparato de Estado absolutista no se correspondía a su pujanza social. Para desarmar a todos esos sectores sociales en crisis, nada mejor que trasladar el centro de gravedad desde el Estado hacia la sociedad, "neutralizar" la fuerza pública. El monopolio de la coacción por el Estado, la desaparición de la "justicia privada", impedían la autodefensa la aristocracia y la realeza.

La separación de poderes, por otro lado, es absolutamente compatible, en los escritos de Locke, Montesquieu, Rousseau, etc. con el principio de soberanía única e indivisible, precisamente porque los poderes, lo mismo que la constitución, se entienden en un sentido formal y no material. Esto es lo que distingue radicalmente a esos pensadores de sus precedentes, y de ahí también su éxito. El cuerpo social o político, lo mismo que el humano, actua guiado por una voluntad; y en la sociedad, la voluntad es el legislativo y el movimiento o acción, el ejecutivo, de modo que no hay partición de la soberanía, y ni siquiera de la fuerza o de la capacidad de coacción del Estado, por lo que tampoco son exactas las teorías de la "autolimitación" del poder del Estado (Ihering, Laband, Jellinek); ni tampoco hay antinomia alguna entre soberanía y constitución, sino todo lo contrario: ésta es una formalización de la titularidad y el ejercicio de aquella.

Nos parece también alejado de la realidad de la época la caracterización del primer constitucionalismo como "Estado de Derecho" (49). Dejando al margen que se trata de un término puramente ideológico y sin ningún alcance explicativo y que, además, no existe ninguna "limitación" -y menos "autolimitación"- del poder del Estado (50), debemos remarcar que no existe sumisión del Estado a la ley, sino a la constitución. La separación de poderes es el núcleo del Estado y de su constitución y, por tanto, no concierne a la sociedad, no tiene ningún carácter garantista sino que atañe exclusivamente a la organización del Estado, de sus poderes, órganos, competencias y funcionamiento.

\section{Tipología de las constituciones de la época revolucionaria}

La separación de poderes se identificaba en la revolución liberal con la misma constitución; pero algunas de sus aplicaciones, que en aquella época no planteaban dudas, hoy se vienen conceptuando como ejemplos evidentes de confusión de poderes (51). Se trata de un principio constitucional que ha sufrió una radical mutación conceptual: desde la óptica actual, sostienen numerosos autores que ni siquiera se ha verificado en constituciones, como la norteamericana (52), de las que se afirma, por otra parte, que son su aplicación más fiel (53), mientras que desde la propia perspectiva de entonces, sí responden al principio otras constituciones, como la francesa de 1793 (54), calificadas hoy como de confusión de poderes (55).

Al exponer hoy usualmente el principio de separación de poderes se está desconociendo la historia, se está olvidando que, como fenómeno social, tuvo 
un origen y una evolución, de modo que no se puede trasladar el pasado -so pena de incurrir en la mitología, como sucede- un concepto tal y como hoy lo entendemos, si nuestra comprensión no coincide con la que tuvo en los orígenes del constitucionalismo. "La separación de poderes -escribió Duguit- es un sistema histórico que para comprender y exponer hay que situar en medio de las ideas que le han hecho nacer... lo que hoy se llama separación de poderes no tiene ninguna analogía con la separación de poderes de la Constitución de 1791" (56). Se afirma hoy día que carece ya de vigencia práctica, que está superado y que sólo estuvo en funcionamiento en los primeros textos constitucionales (57). Pero la separación de poderes tiene una historia: lo que hoy entendemos por tal no coincide con la noción originaria, tal y como los clásicos (Locke, Montesquieu, Rousseau, entre otros) la expusieron y tal y como se puso en práctica en las primeras constituciones.

Se entiende hoy normalmente por separación de poderes la formación de tres órganos (es el número más frecuentemente admitido) dotados de sus correspondientes competencias, situados en un mismo plano constitucional, esto es, situados horizontalmente, convenientemente equilibrados entre ellos (58), independientes (59) unos de otros (no revocables unos por otros) y especializados en el desempeño de sus respectivas tareas (60). Por contra, el concepto originario de separación de poderes significaba única y exclusivamente:

a) que las funciones del Estado no debían concentrarse en un mismo órgano o persona; quien legisla no ejecuta ni aplica la ley porque está sometido a ella lo mismo que todos, y si pudiera ejecutarla o aplicarla, haría excepciones (61), y la primera consigo mismo, mientras que de la otra forma, la ley que promulga puede volverse contra sí cuando la ejecuta o aplica un tercero. Se trataba de un punto de partida puramente negativo, a partir del cual la teoría era compatible con cualquier distribución de competencias que pueda imaginarse (62)

b) la primacía del poder legislativo sobre los demás: no están, pues, los poderes en el mismo plano, sino subordinados al legislativo (63), lo que se manifiesta en:

- la responsabilidad de todos los funcionarios del Estado ante el legislativo - el control por éste de la actividad que desempeñan, del modo en que se ejecuta y aplica la ley

c) unidad del Estado, expresada en la unidad de su voluntad, que es la ley; ésta se caracteriza por su generalidad que se expresa en dos planos fundamentales:

- dimana de una única fuente, la cámara baja, que tiene carácter electivo y representa a toda la nación, a la voluntad general - se encamina a un objeto abstracto y genérico

d) los poderes son fiduciarios: no actuan en interés propio sino de la nación que, en consecuencia, puede exigir responsabilidad y controlar la acción de los mandatarios públicos (64) 
e) unidad del poder ejecutivo, o sea, monopolio sobre la fuerza: en este poder hay competencias de tipo administrativo o gubernativo que se unen a la actividad ejecutiva en sentido estricto, consistente en el empleo de la fuerza cuando es necesaria para cumplir la ley. Además del poder ejecutivo puede administrar también el legislativo ("gobierno de asamblea"), pero es siempre el rey quien dispone de la fuerza que, lejos de limitarse o autolimitarse, se concentra en unas mismas manos.

Los sistemas positivos de distribución de competencias son un problema, desde este punto de vista, secundario: todos ellos son compatibles con la separación de poderes, aunque permiten clasificar las constituciones de la época en dos tipos: mixto y especializado. El sistema mixto, llamado también de balance o equilibrio (tomado del sistema de "gobierno mixto" que promovió tantas discusiones en Inglaterra tras la revolución (65) es un supuesto claro de ausencia de especialización, pues divide el poder legislativo en dos o tres órganos legislativos (el rey y una o dos cámaras) que comparten la facultad de promulgar leyes. Es un sistema de equilibrio o balance no de poderes, sino en el interior del poder legislativo, es decir, del poder supremo.

El sistema especializado se basa en los escritos de Rousseau, Paine, Condorcet y otros, y se caracteriza por una separación casi absoluta de los poderes, de modo que cada uno de ellos propende a especializarse única y exclusivamente en el desempeño de determinadas funciones públicas (legislar, ejecutar, juzgar) concebidas de forma abstracta y genérica. La separación de poderes no está, pues, complementada, como se afirma corrientemente (66), por el balance o equilibrio entre ellos: en ambos sistemas, en todas las constituciones hay un desequilibrio total entre los poderes a causa de la primacía del legislativo.

Ambas concepciones responden a dos ideas sobre el pacto social, sustentadas por otros tantos estamentos sociales:

- para la nobleza y la alta burguesía (que se apoya en los escritos de Montesquieu) el pacto social es un acuerdo con el poder establecido, con las clases ligadas al Antiguo Régimen para compartir la dirección del Estado; se trata de una composición de fuerzas sociales, de cuerpos intermedios calificados de "potencias" y polarizados entre el rey y la nación

- para la pequeña burguesía (pequeños agricultores y comerciantes, cuyas ideas expresan autores como Rousseau, por ejemplo) es un acuerdo dentro de la sociedad (67) para organizar y distribuir el poder ya conquistado; diferenciarán este pacto dentro de la sociedad del "acto por el que un pueblo se somete a los jefes" que es algo distinto, que califican de comisión (68); los cuerpos intermedios no se tienen en consideración dentro de la sociedad, surgiendo la voluntad general de una suma aritmética de voluntades atomizadas e iguales.

La gran burguesía hablará abiertamente de clases sociales, sustentará una posición clasista que negará la igualdad de todos los sectores sociales: cada cual dispone del poder político en función de la clase a la que pertenezca o a la que sirva y, además, cada clase social desempeña un papel distinto y tiene un peso político también distinto. La pequeña burguesía es igualitarista, no 
reconoce clases sociales y disuelve todas las desigualdades -o lo pretendedentro de una categoría uniforme de ciudadano cuyo prototipo es el pequeño propietario.

De aquí derivan también dos formas distintas de responsabilidad, esto es, dos formas distintas de manifestarse la supremacía del poder legislativo. Las constituciones especializadas, al concebir el gobierno como una comisión (sistema convencional) no permiten más que la responsabilidad penal; cualquier incumplimiento de la ley no es más una prevaricación, un delito. Este sistema tan rígido continuaba la tradición jerárquica del Antiguo Régimen, donde el incumplimiento de los mandatos del rey constituía traición, una quiebra del vasallaje debido al soberano (69). En las constituciones mixtas, por contra, se trató de buscar soluciones intermedias entre la impunidad y la muerte; y de ahí nació la responsabilidad política, un instrumento mucho más flexible que permite al comitente destituir a su subordinado, al tiempo que éste se salva de una pena grave e infamante. La responsabilidad política comprendía mucho más supuestos pero sus consecuencias eran considerablemente más livianas (70): de ahí el éxito de estas fórmulas constitucionales.

A ellas responden las constituciones monárquicas, como la francesa de 1791 y la española de 1812, de carácter moderado (71), frente a las más revolucionarias, que son las de carácter especializado, normalmente republicanas, como las francesas de 1793, 1795 y 1848. En las mixtas, la separación de poderes no significaba, en absoluto, que cada órgano del Estado (legislativo, ejecutivo, judicial) ejerciera única y exclusivamente una función (legislar, ejecutar, juzgar), y tampoco significaba que cada órgano fuera independiente de los demás (72). En las constituciones mixtas no se intentó siquiera (73) crear órganos diferenciados con funciones exclusivas y excluyentes, sino todo lo contrario: se formaron órganos competentes para conocer de dos o tres funciones distintas a la vez; se diseñaron funciones compartidas simultáneamente por varios órganos; e incluso, cada órgano se subdividió, a su vez, en dos o más secciones separadas.

Así, el informe de Lally-Tollendal de 31 de agosto de 1789 comienza preguntando a la Asamblea si el cuerpo legislativo se va a componer de uno o más "poderes", haciendo referencia seguidamente a las distintas "porciones" del poder legislativo, y afirma: "Para mantener el balance de la constitución es necesario que la potencia ejecutora sea una rama, sin ser la totalidad de la 'potencia legislativa'", pues de lo contrario ésta se adueñaría de la primera (74). La única diferencia de los sistemas constitucionales mixtos es que mientras la Constitución francesa de 1791 (o la española de 1812) sólo dividía el poder legislativo en dos secciones, otras (la belga, la prusiana) la dividen en tres; no es más que la distinción clásica entre unicameralismo y bicameralismo.

El problema radica en que el rey y la cámara alta no son electivos pero pretenden ser (o se les pretende hacer) representativos, cuando en realidad sus cargos son normalmente vitalicios $y$, además, no fiduciarios sino que defienden prerrogativas estamentales, actuan en beneficio de sus propios intereses. Si pudieran promulgar leyes, éstas no expresarían la voluntad nacional ni se encaminarían hacia el bien común: coexistirían dentro del Estado 
otras tantas voluntades, de modo que para asegurar la unidad del Estado, aquellos constituyentes facultaron a las porciones no electivas del poder legislativo con atribuciones meramente negativas, con la posibilidad de oponerse pero no de estatuir. El rey disponía de veto pero no de iniciativa legislativa; no podía proponer leyes sino sólo evitar temporalmente que se promulgaran.

En cualquier caso, sin embargo, el legislativo se componía del rey y la cámara, y como función, la legislación era una tarea compartida por dos órganos distintos (75). Esta divisibilidad del poder legislativo contrasta con la unificación del ejecutivo en un solo órgano: "reside exclusivamente en la mano del rey", dice literalmente la Constitución de 1791 (76) para asegurar la unidad del poder ejecutivo, la centralización y el monopolio de la fuerza en unos mismos resortes constitucionales.

En esta misma línea de constitucionalismo mixto, la Constitución de Cádiz, por su parte, en su art.15, afirmaba que "la potestad de hacer las leyes reside en las Cortes con el Rey", es decir, que el legislativo se componía de dos secciones, las Cortes y el rey, de donde deriva la sanción de las leyes, que corresponde al rey (art.142) y, por tanto, el veto (77), siquiera sea éste suspensivo (arts.144 y stes.). A esta facultad legislativa hay que añadir sus poderes reglamentarios, de claro carácter legislativo, reconocido ya en el art.V del Capítulo II del Reglamento de la Regencia de enero de 1812, y luego incorporado al art.171-1 de la propia Constitución (78). Las Cortes disponían de importantes facultades gubernativas y administrativas, como la creación y supresión de oficios públicos (art.131-9), la aprobación de las ordenanzas municipales (art.321-8), y del reparto de las contribuciones entre las provincias (art.131-16), el fomento de toda especie de industria (art.131-21), el establecimiento del plan general de enseñanza (art.131-22), etc. Las Cortes disponían de facultades jurisdiccionales para juzgar a sus diputados (art.128), para interpretar las leyes (arts.131-1 y 261-10) (79), para hacer efectiva la responsabilidad de los infractores de la Constitución, en general (art.372) y de los ministros y funcionarios públicos en particular (art.131-25), entre otras (80). Del mismo modo, el rey disponía de trascendentales facultades jurisdiccionales de indulto (art.171-13), para enjuiciar a través de tribunales militares (art.250), para detener (art.172-11), y también los alcaldes (art.275) y los gobernadores civiles (art.261-4) asumían funciones judiciales (81). Sólo la disposición de la fuerza pública es una competencia que permanece indivisa.

Pero en cualquiera de sus modalidades, los primeros constituyentes tenían un concepto formal de constitución, por el que ésta, en expresión de Sieyes, era el medio y las leyes ordinarias el fin (82). El veto y la facultad de impedir, en general, son exponentes de esa concepción formal y puramente técnica de la constitución, en cuanto son negativas y ajenas a determinaciones concretas. En esta misma línea se encuentra el concepto de "tribunado" en Rousseau (83), el recurso de casación, e incluso el propio concepto abstracto de ley como resolución emanada de una voluntad general y con un destino igualmente general. Pero además, la ley al no contener un mandato específico dirigido a ninguna persona concreta, no hacía más delimitar un área de acción: también tenía un contenido meramente negativo, en cuanto que se limitaba a definir el ámbito privado que el Estado -o mejor el ejecutivo- no podía invadir (84). Los 
derechos se declararon ilegislables precisamente porque regularlos positivamente significaba limitarlos. A lo máximo las leyes no decían lo que cada uno tenía que hacer, sino lo que nadie podía hacer. Por eso no se añadió una tabla de deberes y obligaciones a la Declaración de Derechos, pese a las propuestas explícitas al respecto. La ley era la raya que dividía al Estado de la sociedad, y lo dividía obstaculizando la acción del primero de modo que la sociedad dispusiera de las mayores posibilidades de acción (85).

El Estado constitucional "neutro" conduce a una noción puramente funcional e instrumental de la constitución, ajena a los valores y a los derechos y libertades del ciudadano. Sieyes, que utilizaba el término "establecimiento público" en lugar de "Estado", dio la siguiente definición de lo que quería decir: "El conjunto de estos medios, compuestos de personas y de cosas, debe denominarse Establecimiento público, a fin de recordar en todo momento tanto su origen como su destino". Y luego perfiló los contenidos de la Constitución, que según él, abarcaba a la vez:

- la formación y la organización interiores de los diferentes poderes públicos - su independencia necesaria, así cuando su dependencia recíproca - las precauciones políticas con las cuales resulta necesario rodearlos para que no puedan jamás volverse peligrosos.

Y finaliza de la siguiente manera: Tal es el verdadero sentido de la palabra Constitución, a saber: relativo al conjunto y a la separación de los poderes públicos. Por ello, no es la Nación, en modo alguno, lo que se constituye, sino el Establecimiento político. La Nación es el conjunto de los asociados, gobernados y sometidos a la Ley obra de sus propias voluntades", mientras que, por el contrario, los gobernantes "forman bajo esta sola relación un cuerpo político de creación social y, por ende, como todo cuerpo, precisado de organización, límites, etc., por lo que, en consecuencia, ha de ser regulado por la Constitución" (86).

La constitución, por tanto, se refiere al Estado; la ley a la sociedad. El Estado es un organismo inerte y pasivo, cuya única función es preservar los derechos de los ciudadanos. Es en el ámbito privado donde se desarrollan los fines que el Estado debe proteger. El fin de las asociaciones políticas, dirá Rousseau, es "la conservación y la prosperidad de sus miembros" (87), expresión que su fiel discípulo Robespierre copiará: "El objeto de toda asociación política -rezaba el art.1 de la Declaración de Derechos que propone- es el mantenimiento de los derechos naturales e imprescriptibles del hombre, y el desarrollo de todas sus facultades".

De manera que la constitución es extraña a concreciones axiológicas, carecía de parte dogmática: los derechos y libertades constaban al margen, antes de la constitución en Francia, o después de ella en Estados Unidos. La Declaración de Derechos debía ponerse al frente de la Constitución, proponía Sieyes, para guiarse por ellos, "para proporcionar al pueblo francés un punto de comparación" (88). Era un reflejo del Derecho Natural, un punto de referencia metapositivo que permitía valorar la actividad pública y autorizaba la resistencia y la desobediencia cuando se infringían. La constitución cambia de un país a otro, en tanto que norma positiva, creación humana, en definitiva y, por tanto, modificable: "La constitución del hombre es obra de la naturaleza -sentencia 
Rousseau- la del Estado es obra del arte" (89). Por el contrario, las Declaraciones de Derechos son obra de la naturaleza; los "derechos" allí enunciados son inviolables, "sagrados", imprescriptibles, inalienables y comunes a todos los pueblos: "La Declaración de Derechos es la Constitución de todos los pueblos", dirá Robespierre (90). Y Hegel también dejará claro que la constitución es sólo organización del Estado y del poder del Estado: "La constitución política- afirmará- es la organización del estado y el proceso de su vida orgánica en referencia a sí mismo" (91).

Que se redacten constituciones, como la española de 1812, sin Declaración de Derechos (92) no es un defecto técnico, sino una debilidad política de nuestro liberalismo, una concesión que al mismo tiempo pretende reforzar la inmunidad de la gestión pública frente a la crítica ciudadana. Es por ello que, con el fin de compensar, la Constitución de 1812 multiplica los enunciados tendentes a dejar clara la naturaleza fiduciaria de los poderes (arts.4 y 13) como única posibilidad de control de la autoridad pública.

Ha contribuído a desdibujar el sentido originario de la constitución como constitución puramente formal, el art.16 de la Declaración de Derechos de 1789, según el cual "toda sociedad en la cual la garantía de los derechos no está asegurada, ni la separación de poderes determinada, carece de constitución". Parece que aquí se establece un doble contenido necesario de la constitución: una parte orgánica y una parte dogmática. Autores como García Pelayo (93) y Tomás y Valiente consideran que la concepción formalista y positivista del Estado no es la propia del liberalismo originario (94) que, según este último autor, perfila nítidamente una serie de valores y fines del Estado, tales como la propiedad, la libertad, la seguridad y, a veces, la igualdad. A mi entender, la constitución -lo mismo que el Estado- es ajena a cualquier contenido finalista, a toda determinación teleológica, que debe remitirse al mundo económico privado, al mundo del mercado y del Derecho privado, dominado por las ideas de equidad, justicia, etc. Y es también ajena y distinta a las Declaraciones de Derechos, que son normas metapositivas y extrajurídicas, de manera que se encuentran constituciones sin Declaración de Derechos (como en España), o con Declaraciones de Derechos anteriores (Francia) o posteriores (Estados Unidos) a la constitución y siempre al margen de ella. El art.16 de la Declaración de 1789 debe, pues, entenderse de ese modo, como, por otra parte, establece su contenido literal: no se refiere para nada al Estado, sino a la sociedad en general; no habla de derechos en concreto, sino en abstracto, lo que debe entenderse en el sentido de que alcanza tanto a los derechos particulares y privados, cuya garantía es el poder judicial, y los "derechos" y libertades públicas, cuya garantía es el poder legislativo; y en cuanto al modo de garantizarlos, si se trataba de derechos privados, se efectuaba por medio de leyes uniformes y códigos, y si se trataba de los "derechos" y libertades políticas, a través del sufragio. En consecuencia, en un caso la Declaración de Derechos conducía a su opuesto, al Derecho positivo, y en el otro a la constitución, entendida siempre como forma de organización y funcionamiento del Estado y sus diversos poderes (95). 


\section{La supremacía del poder legislativo y sus límites}

La innovación de Locke Montesquieu y, sobre todo, Rousseau, dentro de la historia de las ideas políticas no radicó en la clasificación y distribución de las funciones del Estado. Son innumerables las que antes que ellos se habían ideado de las labores del Estado, en particular las resultantes del gobierno mixto. Locke y Montesquieu pretendieron, a diferencia de sus predecesores, establecer una clasificación formal y no material de las funciones estatales (96), integradas por un impulso inicial, la voluntad, y un movimiento posterior, la actividad. El funcionamiento del Estado se resumía en un Parlamento encargado de elaborar la ley, mientras los demás debían ejecutarla: "Tal es la 'forma' del sistema", afirma Nieto (97). Todo el funcionamiento del Estado se resumía en una decisión original, legislativa, y una actuación posterior de ejecución (98). "Los hombres se han de dirigir por reglas fijas y sabidas de todos -afirma el Discurso Preliminar- "y su formación ha de ser un acto diferente de la ejecución de lo que ellas disponen. Las diferencias o altercados que puedan originarse entre los hombres, se han de transigir por las mismas reglas o por otras semejantes, y la aplicación de éstas a aquellos no puede estar comprendida en ninguno de los dos primeros actos" (99). Clasificar en cuanto al fondo o contenido las actividades del Estado y colocar al frente de ellas a un órgano calificado de poder, contribuía a confundir el gobierno mixto con la separación de poderes.

La incongruencia de Locke y Montesquieu -que Rousseau evitó- fue añadir a esta clasificación formal, otros dos poderes definidos materialmente: el federativo y el judicial. Demostraban las dificultades políticas existentes para articular constitucionalmente un reparto formal y abstracto de las competencias, adveradas en España por los sucesivos cambios introducidos en los reglamentos de la regencia, que van desde un reparto primitivo formal, teórico y genérico, muy favorable para los revolucionarios, hasta otro material y concreto, más ajustado, "equilibrado" para las dos fuerzas sociales en liza. El poder federativo de Locke no era una forma de actuación del Estado, sino un área de funcionamiento, la relativa a la política exterior. Del mismo modo, el poder judicial en Montesquieu se define materialmente como aquel que resuelve los litigios individuales, como una de las actividades del Estado de carácter ejecutivo: no es que Montesquieu sostuviera que el poder judicial es una parte del poder ejecutivo, sino que en términos de Paine (100), Duport (101) o Hegel (102), la actividad judicial, que puede estar encomendada a un órgano separado, funciona exactamente igual que el ejecutivo, esto es, subordinado a la ley que debe cumplir. Y esto es en el pensamiento clásico lo decisivo: no lo que los poderes hacen, sino cómo lo hacen, y el ejecutivo y el judicial son poderes ejecutivos idénticos (103) por su forma de funcionamiento pero atribuídos a órganos diferentes.

Esa concepción formal de los poderes implica necesariamente que no son independientes, sino que hay uno, el legislativo, por encima de los demás (104). Esto es algo, además, políticamente consustancial al concepto originario de división de poderes en cualquiera de los dos sistemas constitucionales; no son iguales, no están equilibrados ni al mismo nivel, sino que se subordinan al legislativo (105). Sólo éste es independiente y, por tanto, sólo son 
independientes las cámaras y el rey. Pero si el rey actua como poder ejecutivo (y lo mismo sus ministros y agentes) no es independiente de la otra parte del poder legislativo, es decir, de las Cortes, pues si así fuera podría infringir la ley, imponer su propia ley. No es directamente responsable, pero sí a través de sus ministros, y necesita el refrendo de éstos para que sus disposiciones tengan fuerza ejecutiva (art.225 de la Constitución de Cádiz). Los primeros intentos de responsabilizar a los ministros se remontan a la Inglaterra del siglo XIII, ensayándose tres vías diferentes: la elección, el juramento (en virtud del cual no podrían "servirse de su situación oficial para satisfacer su avaricia o acrecentar sus riquezas") y la amenaza de destitución (106). La recepción por la Cámara de los Comunes de las peticiones y quejas "constituye el reconocimiento más completo del derecho de los comunes de controlar el conjunto de la administración y de pedir reformas administrativas tanto como nuevos estatutos" (107). Instrumento de esta responsabilidad ministerial (un régimen parlamentario embrionario) era en Francia la responsabilidad penal y el sistema de Altos Tribunales (108). "Los ministros -decía la Constitución de 1791- son responsables de todos los delitos por ellos cometidos contra la seguridad nacional y la Constitución; de todo atentado a la propiedad y a la libertad individual; de toda disipación de los fondos destinados a los gastos de su departamento". La responsabilidad parece derivar tanto por acción como por omisión e incluso por negligencia, una redacción lo suficientemente flexible como para permitir, además de las consecuencias penales ordinarias, las políticas, es decir, la destitución y la revocación.

La superioridad del legislativo quedaba perfectamente de manifiesto en la responsabilidad de los funcionarios y agentes públicos (superioridad por razón del sujeto), así como en el control y fiscalización de la actividad y el funcionamiento de los órganos (superioridad por razón del objeto), o bien en instituciones como el refrendo ministerial, si nos referimos al gobierno. Los cuadernos de los Estados Generales contenían ya numerosas menciones a la necesidad de regular la responsabilidad de los miembros del ejecutivo: "La responsabildad de los agentes del poder -escribe Lair- más particularmente de los ministros, no solamente la responsabilidad política, sino la responsabilidad judicial, ha sido una de las reformas más ardientemente, más universalmente reclamadas por los cuadernos de los Estados Generales" (109), añadiendo también que "la mayor parte quiere que los principios que regulen la responsabilidad penal de los ministros se extienda a los principales funcionarios" (110). Cuando Clermont-Tonnerre resume ante la Asamblea el 27 de julio de 1790 el contenido de los cuadernos, recoge en su número tercero la demanda generalizada de responsabilidad de los funcionarios (111). Mirabeau destacó entre quienes se esforzaron por salir de las responsabilidades estrictamente penales y hallar respuestas intermedias entre la muerte y la impunidad total (112). El proyecto Mounier, presentado el día 27 de julio, regulaba igualmente la responsabilidad de los ministros y funcionarios públicos (113), lo mismo hacía el de Lally-Tollendal, el de Chapelier de 25 de octubre y, sobre todos, el de Robespierre, que afirmaba que "un pueblo en el que los mandatarios no rindan cuentas a nadie, no tiene constitución" (114), materializado en el art.24 de la Declaración jacobina de Derechos, según el cual no hay libertades ni derechos "si no se garantiza la responsabilidad de todos los funcionarios". 
El primer Decreto de las Cortes de Cádiz de 24 de setiembre de 1810 declara que "el Consejo de Regencia, para usar de la habilitación declarada anteriormente, reconocerá la soberanía nacional de las Cortes, y jurará obediencia a las leyes y decretos que de ellas emanaren". El poder ejecutivo era una delegación que hacían las Cortes en regencia, cuyos miembros "quedan responsables a la Nación por el tiempo de su administración, con arreglo a las leyes". El Decreto de 16 de enero de 1811 declaraba "amovibles a voluntad de las Cortes" a los regentes. El Decreto de 14 de julio de 1811 es una de las pruebas más claras de la precocidad de los constituyentes españoles, que se anticipan en la búsqueda de soluciones puramente políticas, como la remoción, única medida que este Decreto contempla, frente a la infracción de la legalidad por los funcionarios. El Capítulo IV del de 26 de enero de 1812 declaraba a los regentes "responsables a las Cortes por su conducta en el ejercicio de sus funciones", así como también a los ministros "sin que sirva de excusa haberlo exijido la Regencia", hasta el punto de poder ordenar las Cortes "la formación de causa" si no aprobaban "la conducta" de regentes o ministros (115).

La Constitución española de 1812 arbitró luego formas de responsabilidad que, incluso son muy superiores a las francesas. No es el caso, sin embargo, de los juicios de residencia de funcionarios del art.261.6, por tratarse de un mecanismo jurídico anticuado (116) y por encomendarse su decisión al Tribunal Supremo (117), un órgano no vinculado al legislativo, como en Francia, sino al ejecutivo. A diferencia también de la Constitución francesa de 1791, que sólo admitía la responsabilidad penal (118), contiene (arts.226, 228 y 229), siguiendo los decretos citados, supuestos bastante claros de ejercicio de una primitiva "moción de censura" (119): tal parece ser el significado de los números 2 (responsabilidad política) y 4 (responsabilidad penal) del art.261 de la Constitución de Cádiz (120), criterio que fue continuado luego por los decretos de 24 de marzo y 8 de abril de 1813 (121). La irresponsabilidad del monarca (art.168) e incluso de los regentes (inaugurada por el decreto de 24 de marzo de 1813), unido al refrendo ministerial (art.225), y luego al "régimen parlamentario" no hicieron más que perfeccionar esta supeditación a las Cortes del ejecutivo (que no del rey como parte del poder legislativo).

La supremacía del poder legislativo y la negación de la independencia de los demás poderes, fue remarcada por Hegel -un fiel seguidor y expositor del pensamiento de Montesquieu- con términos que merecen ser recordados:

El principio de la separación de los poderes contiene el momento esencial de la diferencia, de la racionalidad real; el entendimiento abstracto la aprehende en cambio falsamente como la absoluta independencia recíproca de los poderes, o bien unilateralmente, comprendiendo su relación como algo negativo, como su mutua limitación. Desde esta perspectiva, se transforma en hostilidad, en temor de cada uno frente al otro como si fuera un mal, lo que dará lugar a que se contrapongan y a que de su contrapeso resulte un equilibrio general, pero no una unidad viviente. Lo que encierra el origen absoluto de los diferentes poderes no es un fin o una utilidad cualquiera, sino únicamente la autodeterminación del concepto en sí mismo... Con la independencia de los poderes, por ejemplo de los llamados ejecutivo y legislativo, está inmediatamente puesta la desintegración del estado. $\mathrm{O}$, si se mantiene lo 
esencial del estado, la lucha por la que un poder se subordina a otro, dando por resultado la unidad, de cualquier manera que ésta se realice, y salvando sólo así lo esencial, la existencia del estado (122).

De la superioridad del legislativo deriva también la preeminencia de la ley en instituciones como el "référé legislatif" o de la casación, cuando se trataba del poder judicial. El "référé legislatif" prevenía una posible resolución "contra legem" de los tribunales; la casación la remediaba una vez producida (123). El "référé legislatif" ponía una interpretación auténtica, la del legislativo, por encima de la de los tribunales; la casación dimanaba de un órgano, al que se llamaba "Tribunal", pero que en realidad era un "anexo" de la Asamblea, según la Ley de 1 de diciembre de 1790, y que, por otra parte, no interpretaba la ley, sino que simplemente reconocía cómo no se debía interpretar. Por contra, en España no existe este remedio procesal; el Tribunal Supremo aquí es un órgano de control político (124) sobre los jueces, magistrados y los funcionarios públicos en general, y no aparece ligado al legislativo, sino al ejecutivo.

Otra demostración de superioridad es el desconocimiento de los conflictos de atribuciones entre el legislativo y los otros dos poderes. Sólo podían existir, en todo caso, conflictos dentro del mismo poder legisaltivo, entre el rey y la cámara (125), resueltos por medio del veto. Los conflictos entre poderes que comienzan a regularse son los entablados entre los poderes subordinados, entre el judicial y el ejecutivo, y quien los resuelve es el legislativo, precisamente porque es quien está por encima de ellos (126).

El problema de la supremacía del legislativo planteaba, sin embargo, importantes problemas en ambos tipos de constituciones, porque podía conducir a la concentración de poderes (127). Era especialmente grave -para la aristocracia- en las constituciones especializadas, al dejar las manos libres a la Asamblea para invadir, por medio de leyes formales la competencia del ejecutivo, de ejecutar por vía de ley, procediendo a una concentración de poderes encubierta. Es aquí donde entran en juego los distintos sistemas de "límites" al poder legislativo, que no eran más que eso precisamente: límitaciones puestas a la supremacía de la Asamblea y no limitaciones de la soberanía ni del poder del Estado. Las constituciones especializadas marginaban totalmente al rey y a la aristocracia, por lo que la solución a la supremacía del legislativo era dividir este poder y hacerlo compartir entre diversos órganos integrados por aquellas clases que, en otro caso, quedarían fuera del poder supremo, proyecto ya claramente definido por Lally-Tollendal cuando propone el bicameralismo, e incluso antes por Montesquieu, que propone el veto: "Si el poder ejecutivo no posee el derecho de frenar las aspiraciones del cuerpo legislativo -había escrito Montesquieu- éste será despótico, pues, como podrá atribuirse todo el poder imaginable, aniquilará a los demás poderes" (128). Mucho más claro fue Constant, quien justificó el veto afirmando que "una Asamblea cuyo poder es ilimitado es más peligrosa que el pueblo" (129). El veto, en cuanto "intercessio" o "legislador negativo", aseguraba la unidad de la voluntad del Estado: no había dos voluntades porque el veto carecía de determinaciones positivas, no manifestaba una intención concreta sino que se limitaba a impedir la expresión de la voluntad general. Los órganos no electivos y no representativos que intervienen en el poder legislativo, lo mismo que el Tribunal de Casación, sólo disponen de una 
facultad meramente negativa; impiden la efectividad de la voluntad general pero no pueden manifestar una voluntad propia.

Pero Rousseau, contrario al veto, ya había dejado claro que los límites a la supremacía del poder legislativo en las constituciones que él diseña eran meramente internos, relativos al propio concepto de ley, como disposición no solamente fruto de la voluntad general, sino atinente a una cuestión de interés general, al bien común (130). Las leyes no pueden contener excepciones, ni pueden hacerse excepciones en su ejecución, por lo que no se promulgarán leyes -cabe pensar- cuya aplicación perjudique a alguien, ya que perjudicarían igualmente a todos, a los propios que las redactan. Si la ley la ejecuta un tercero es más probable que afecte al legislador lo mismo que a cualesquiera otras personas particulares. La generalidad de la ley y su uniforme aplicación e interpretación son las mejores garantías. Las leyes formales serían contradicciones en los términos, metafísicamente imposibles. En Rousseau la Asamblea sólo puede emitir leyes (131), lo cual es todo lo contrario del principio de que todo lo que dimana de la Asamblea es una ley, que es el que enuncia el art.92 de la Constitución termidoriana, prototipo de autorización de leyes formales: "Las resoluciones del Consejo de los Quinientos -decía aquel artículo- adoptadas por el Consejo de Ancianos, se llaman leyes". Se llamaban leyes, ciertamente, pero no eran leyes, en el sentido de Rousseau.

Ahora bien, esto que filosóficamente puede ser aceptable, no lo es jurídicamente y, además, no hace más que trasladar el problema sin resolverlo: no se trataría de una invasión de competencias, de un exceso de poder, sino de una cuestión de calificación jurídica, de discutir si un reglamento, la firma de un tratado, la aprobación de los presupuestos, etc. son actos de legislación o de ejecución. No hay una decisión previa del problema, que queda aplazado y a merced de posterior interpretación, siempre insegura. Es mucho más sencillo plantear el problema no teóricamente, sino en la práctica: partir de las labores que debe desempeñar el Estado y repartirlas entre los poderes. Desde el punto de vista teórico-jurídico puede no ser correcto 0 coherente, pero es tremendamente práctico por lo dúctil. Fue la gran ventaja de las constituciones mixtas.

\section{Las tres racionalidades de la separacion de poderes}

Hablaremos, por tanto, de dos tipos distintos de reparto de competencias tanto en unas constituciones como en otras. Un reparto formal, abstracto y genérico, y un reparto material, específico o concreto; un reparto formal que atiende a la calificación de la actividad del Estado, bien como legislación o bien como ejecución, y un reparto material mucho más complejo y detallado, que reparte cada una de las funciones públicas entre unos u otros órganos. Importa, no obstante, dejar bien claro que no se puede confundir la separación de poderes con ninguna de esas dos formas de repartir las funciones del Estado, que la separación de poderes no consiste sólo en repartir y distribuir la competencia, sino que se refiere también al funcionamiento de los poderes del Estado, a la constitución de sus órganos y al modo de relacionarse entre sí.

Pero antes de entrar en este punto, conviene insistir en los objetivos que la burguesía perseguía al implantar la separación de poderes. García Pelayo ha 
hablado (132), en este sentido, de una racionalidad técnica y de una racionalidad axiológica. Por contra, entiendo que esta segunda, por el carácter formal de la constitución en aquella época, no existe, y que la racionalidad técnica es de carácter secundario respecto a otro tipo de racionalidad, que no ha llamado tanto la atención en la literatura jurídica: la política. Entramos, pues, en el examen sucesivo de estas tres cuestiones: primero el aspecto técnico o funcional de la separación de poderes; luego la inexistencia de la racionalidad axiológica; y finalmente, la vertiente política o social de la separación de poderes, que me parece la fundamental.

Para los primeros constituyentes franceses la separación de poderes hace referencia, tanto a la cuestión material o competencial, a lo que se va distribuir, como a los órganos que van a asumir esas atribuciones, ya repartidas. La verdadera medida de cada uno de esos poderes estará en función, primordialmente, del bloque de atribuciones que acapare; no importa tanto el órgano como las atribuciones que le correspondan. El reparto de las competencias del Estado entre diferentes órganos no divide el poder, pero es una de las expresiones del poder de cada uno de ellos. Las atribuciones que cada poder (y cada órgano dentro de cada poder) recibe de la Constitución, acaba finalmente difiniendo y configurando al poder y al órgano competente más que cualquier otro factor; el órgano no obtiene sus competencias en base a su título o a su nombre, porque ese es el punto de llegada, nunca el de partida (133).

El desarrollo de lo contencioso-administrativo, como veremos, impondrá otra delimitación de competencias entre los tres poderes, construída sobre principios tales como "juzgar a la Administración es administrar", debe concederse competencia a la Administración sobre todo lo que deriva de la propia Administración, etc. El resultado final de esta evolución, sin embargo, no puede aceptarse como punto de partida científico, sino que hay que iniciar el camino de regreso hacia los orígenes. Ni siquiera en Francia es válido ese criterio, que es el que Laband (134), Carré de Malberg (135) y Hauriou (136) emplean. Incurre en un nominalismo que nada aclara, porque no va más allá del ámbito jurídico, solapando las realidades políticas que subyacen, algo que Carl Schmitt calificó de "aberración” (137).

Este aspecto de la separación de poderes podría calificarse de técnico y jurídico, y tiene un marcado carácter utilitarista: la separación de funciones, la división del trabajo político, la racionalización y optimización del funcionamiento del Estado. En el Antiguo Régimen, la venta de oficios (138) condujo a una proliferación burocrática que no respondía a necesidades reales de funcionamiento; había más puestos que tareas; la maquinaria absolutista operaba en el vacío (139), estaba organizada más por exigencias fiscales que de servicio. Esa maquinaria obsoleta significaba un enorme dispendio que la burguesía sufragaba, mientras sus beneficiarios eran los nobles y aristócratas, cada vez más enclaustrados en oficios meramente rentistas y parasitarios, que les proporcionaban unos cargos influyentes que no se correspondían con su lugar en el mercado económico.

La separación de órganos era reflejo de ese aspecto político; la división de funciones responde al aspecto técnico, económico o jurídico. Quienes como 
Jellinek o Loewenstein sólo reconocen un mero aspecto de división de funciones, pero no de poderes, incurren en un formalismo que camufla el aspecto político subyacente. La configuración de los órganos constitucionales, aún prescindiendo del reparto de competencias, es un factor decisivo de poder político. Así, deberá diferenciarse entre los cargos vitalicios, propios del absolutismo, de los cargos temporales y electivos de la revolución; habrá que distinguir igualmente aquellos organizados sobre un principio comisarial, de aquellos que se apoyan en uno funcionarial u oficial. Así, por ejemplo, mientras los jueces franceses son elegidos temporalmente para sus funciones, los españoles los nombra el rey y son vitalicios.

Es importante consigar también, en cuanto al aspecto técnico o competencial, que no a todas las funciones se les concedió la misma importancia política y jurídica; ni tampoco fue lo mismo la alternativa de dar una competencia al legislativo o al ejecutivo, que a éste $o$ al judicial. Las funciones decisivas fueron siempre la guerra (a lo que va unido las relaciones exteriores) y la hacienda (140). En cuanto al aspecto orgánico o político, tampoco todas las separaciones tenían la misma importancia; la más trascendental, por ser la más relevante políticamente, fue -en el sistema mixto- la operada dentro del legislativo, ya que era la que marcaba las respectivas cotas obtenida por los segmentos sociales en pugna: la burguesía y la aristocracia terrateniente. La separación, dice el Discurso Preliminar de 1812, es "indispensable"; pero a partir de ahí vienen los problemas: "Los límites que se deben señalar, particularmente entre la autoridad legislativa y ejecutiva para que formen un justo y estable equilibrio, son tan inciertos que su establecimiento ha sido, en todos los tiempos, la manzana de la discordia entre los autores más graves de la ciencia del gobierno, y sobre cuyo importante punto se han multiplicado al infinito los tratados y los sistemas". Y poco más adelante concluye: "La Constitución ha mirado como esencialísimo todo lo concerniente a las limitaciones de la autoridad del Rey". El Discurso considera haber resuelto el problema no por doctrinas, conjeturas, prestigios filosóficos ni por "principios de teoría política", sino en base a la antigua legislación española, donde "el Rey participaba en algún modo de la autoridad legislativa" (141). Frente a la delicada problemática -política- de la separación entre esas dos decisivas "potencias", la importancia del reparto de competencias entre el ejecutivo y el judicial era insignificante (142). Subyace aquí otro problema: el poder como factor de fuerza en función de la cantidad y calidad de las competencias que le correspondan y, por tanto, la posición en la que quedarán las clases sociales representadas por cada uno de los poderes.

\subsection{Formas de distribución de competencias (la racionalidad técnica)}

Las constituciones especializadas se caracterizarán por una atribución formal y genérica de competencias en favor del legislativo: la facultad de hacer las leyes permitía administrar a través de leyes en sentido formal. Aquí sí que importa poco el contenido de la norma y solamente el órgano de procedencia: es el sistema formal llevado a sus últimos extremos. En las constituciones especializadas, con un reparto formal, como el que parece que trata de llevar a cabo la Constitución jacobina (arts.53 y 65), no hay problemas de reparto sino de calificación. Si la Asamblea dispone de la facultad legislativa lo que importa es saber si los reglamentos son leyes, si interpretar las leyes es crearlas, etc. $Y$ 
no importa repartir porque todas las constituciones especializadas se redactaron después de otras tantas revoluciones: los liberales acaparan todo el poder y no necesitan compartirlo; no hay una división de competencias, sino una división de los distintos momentos de cada competencia. El art.65 de la Constitución jacobina decía que el ejecutivo no podía accionar sino en cumplimiento de una resolución previa de la Asamblea: ante los imprevistos quien tenía la iniciativa no era el ejecutivo, sino el legislativo.

En las constituciones mixtas, donde el reparto es material, no es posible que el rey y la Asamblea compartan todas las competencias simultánea 0 sucesivamente: cada cual decide sobre sus propias atribuciones. Las competencias de los poderes dejan de ser universales (143); de aquí las habilitaciones genéricas y residuales de competencias en favor del poder ejecutivo, propias de esta forma de reparto: éste disponía de capacidad de iniciativa para actuar en ausencia de ley. En definitiva, ¿acaso existen cuestiones propiamente legislativas y otras propiamente ejecutivas? ¿Qué significa el hecho de que en la Constitución de 1812 la aprobación de las ordenanzas municipales se atribuya a la competencia de las Cortes (144), por ejemplo? ¿Podía el legislativo resolver sobre cualquier asunto con tal de que lo hiciera en forma de ley, o tenía limitada su intervención a ciertas áreas? ¿Por qué determinados "actos parlamentarios" requerían sanción regia, y no otros? Verdaderamente todo esto tiene muy poco que ver con la separación de poderes, por cuanto no implica más que una modalidad posible de su puesta en práctica, pero puede conducir a su eliminación, a la confusión de poderes en la Asamblea legislativa, que es el riesgo de las constituciones especializadas y de los repartos formales de competencias.

Por tanto, la separación de poderes es compatible con que los poderes tengan competencia universal o ilimitada, como es el caso de la Constitución de 1793. Lo que los clásicos criticaban del absolutismo no era que todas las competencias fuesen del monarca, sino que éste legislase y ejecutase a la vez. Por supuesto, cuando las constituciones mixtas proceden a un reparto material y concreto de competencias, nos encontramos nuevamente con otra "limitación", pero no se trata más que de una obviedad que sólo concurre en tales casos pero no en los repartos formales, como el derivado de los arts.53 y 65 de la Constitución jacobina.

Las constituciones mixtas se separaron de los clásicos y de los repartos formales y genéricos a que parecían conducir sus escritos (145). Pero el reparto material no es necesariamente consustancial a ellas, sino simplemente más apropiado para sus objetivos políticos de equilibrio y balance, por cuanto permiten mucha más flexibilidad, una gama infinita de matices. En la española de 1812, por ejemplo, el art.131 sólo permite a las Cortes resolver sobre las cuestiones allí especificadas, mientras que no hay límite a las facultades del rey, que dispone una habilitación genérica, además de su propio repertorio casuístico de competencias, sistema aleatorio que sigue incluso con los entes locales electivos (arts.321 y 335), pero no con los de designación gubernativa, como el jefe político (art.324). En los repartos materiales son frecuentes las habilitaciones genéricas, que resuelven la posibilidad de cualquier omisión o imprevisto y que, por ello mismo, otorgan la iniciativa al ejecutivo, permitiéndole actuar en ausencia de ley. Refuerza, por tanto, el poder del rey como jefe del 
ejecutivo y de la Administración. No hay, en tales casos, límites efectivos a la competencia del rey sino sólo la preexistencia de ley.

De seguir el criterio de Locke y Montesquieu, las primeras constituciones no hubieran procedido a un reparto material de competencias, porque no hubiera hecho falta repartir nada: cualquier asunto sería a la vez competencia del legislativo y del ejecutivo; el primero debe tener prevista la norma general, y el segundo cumplirla cuando llegue el caso. Ambos son competentes sobre los mismos asuntos o, en palabras de Hegel, "cada poder es una totalidad" (146). Este sistema aparece apuntado en el primer Decreto de las Cortes de Cádiz, por el que se reservaban el poder legislativo, mientras que delegaban el poder ejecutivo en la regencia. Al preguntar la regencia cuáles eran sus deberes y cuáles sus atribuciones, las Cortes replican diciendo que el poder ejecutivo dispone de "todo el poder que sea necesario para la defensa, seguridad y administración del Estado". El reglamento de 16 de enero de 1811 señala límites en cuanto al legislativo, por la imposibilidad de dispensar la observancia de las leyes, en cuanto al judicial, para conocer de los asuntos judiciales, y luego se centra en las tres grandes áreas fundamentales (hacienda, guerra y asuntos internacionales) donde su actividad estará fuertemente condicionada por el concurso de las Cortes, sujetas siempre a un régimen especial y cambiante, ajeno a la concepción actual de la separación de poderes.

El problema fundamental es que no define qué son asuntos judiciales ni en qué consiste la ejecución de las leyes. Ahora bien, el reglamento de 1811 emplea varias veces la palabra "medida" para referirse a la actuación del ejecutivo, lo que reconduce siempre a la diferenciación entre leyes y medidas, y ley en sentido formal y material (147) que permiten el "gobierno de asamblea" del mismo modo que en las constituciones mixtas una parte de la administración la asume el cuerpo legislativo.

Por contra, el reglamento del siguiente año es mucho más preciso y desarrolla todo un conjunto de competencias del ejecutivo, empleando términos tales como "disponer" de la fuerza armada, "dirigir" las relaciones exteriores, "cuidar" de la recaudación de tributos y de la fabricación de moneda, etc. Y añade que "las facultades de la Regencia serán las que quedan expresadas en los artículos anteriores, y no otras; teniéndose por abuso de autoridad todo lo que sea excederse de ellas; a no ser que las Cortes en señalada ocasión, y por particulares motivos y circunstancias se las amplíen en el modo que crean conveniente". Este mismo será el régimen de la Constitución de 1812, si bien las facultades no están a la disposición de las Cortes.

No se trata de un proceso de transformación de un "gobierno de asamblea" en otro de "colaboración de poderes" (148), sino de una forma distinta de distribución de competencias, indicativa de un proyecto especializado de constitución, más radical, que cristaliza en otro distinto, más conservador.

Pero éste es ya un sistema material de distribución de competencias, equiparable al de la Constitución francesa de 1791. Las primeras constituciones ampliaron la inconsecuencia inicial de Locke y Montesquieu, al abandonar el reparto formal en beneficio del material. Pero material -es importante aclararlo- no porque exista determinada actividad intrínsecamente vinculada a uno u otro órgano, sino material porque se reparten las 
competencias en función del contenido. Es un criterio político y no jurídico lo que separa a un determinado reparto de otro. Si el art.171.1 de la Constitución de Cádiz concede al rey la facultad reglamentaria, no es porque considere que forma parte de la actividad ejecutiva, ni porque pretenda hacer una excepción a la separación de poderes; y si el art.131.17 otorga a las Cortes competencia para "establecer las aduanas y aranceles de derechos" no es porque considere que es una actividad legislativa, ni otra excepción a la separación de poderes. En ambos casos se apoya sobre criterios políticos y prácticos: no siempre es posible ejecutar bajo ley previa; no siempre conviene dejar la ejecución en manos del rey y sus ministros. El rey puede legislar y la Asamblea administrar; esto es totalmente compatible con la separación de poderes y no meras excepciones. Desde este punto de vista, hay especialización: la solicitud de préstamos es una tarea que compete única y exclusivamente a las Cortes (art.131.14), pero no es de naturaleza legislativa, sino ejecutiva; es decir, las Cortes están especializadas en determinadas funciones, pero estas funciones son tanto legislativas como ejecutivas, de modo que unas requieren sanción del rey y otras no. Las facultades administrativas podían fraccionarse, resultando algunas de ellas competencia de las Cortes y otras del ejecutivo; pero nada de eso sucedía con el mando sobre la fuerza pública, que permanecía siempre indiviso.

\subsection{Libertades publicas y libertades privadas (la inexistencia de racionalidad axiologica en la separacion de poderes)}

Es indudable, por tanto, que la separación de poderes no se puede reducir a un puro criterio técnico, por más funcionalmente que se conciban las primeras constituciones, sino que hubo una vertiente política. Ahora bien, antes de entrar en el aspecto político de la separación de poderes, conviene volver a recordar la inexistencia de ninguna racionalidad axiológica en la constitución; pese a lo que se afirma actualmente (149), la vertiente política de la separación de poderes no tiene por objeto garantizar la libertad de los ciudadanos. En alusión a Roma, Montesquieu observó que "los tres poderes pueden estar bien distribuídos en lo que atañe a la libertad de la constitución, aunque no lo estén respecto a la libertad de los ciudadanos". Y con carácter más general sostuvo:

No basta con tratar la libertad política en su relación con la constitución; hay que estudiarla también en su relación con el ciudadano.

Ya he dicho que, en el primer supuesto, la libertad se basa en cierta distribución de los tres poderes; pero en el segundo hay que considerarla partiendo de otra idea. En este sentido consiste en la seguridad o en la opinión que cada uno tiene de su seguridad.

Puede ocurrir que la constitución sea libre y que el ciudadano no lo sea, o que el ciudadano sea libre y la constitución no. En tales casos la constitución será libre de derecho y no de hecho, y el ciudadano será libre de hecho y no de derecho.

En relación con la constitución son sólo las disposiciones de las leyes, y más exactamente de las leyes fundamentales, quienes dan origen a la libertad. Sin embargo, en relación con el ciudadano, pueden originarla las costumbres, 
hábitos y ejemplos recibidos, y pueden favorecerla ciertas leyes civiles, como vamos a ver en este libro.

Además, como en la mayor parte de los Estados la libertad aparece comprometida, contrariada o limitada más de lo que determina su constitución, conviene hablar de las leyes particulares que, en cada constitución, pueden favorecer o contrariar el principio de la libertad de que cada uno de ellos es susceptible (150).

Se trataba, por tanto, de la "libertad política": no de derechos subjetivos individuales, sino de la libertad de la burguesía como clase social, de su parte en el poder del Estado, identificada por la propia separación de los poderes. El Discurso Preliminar de 1812 admitía la posibilidad de que en un Estado libre pueda haber personas que por circunstancias particulares no concurrieran en la formación de las leyes positivas (151). Y el art.19 de la Constitución francesa de 1848 decía que "la separación de poderes es la primera condición de un gobierno libre". Se trataba de eso precisamente, de un Estado libre, de una constitución libre, no de la seguridad ni de los derechos y libertades individuales. Era un reflejo, en definitiva, del reparto del poder político entre la burguesía emergente y la vieja aristocracia señorial, lo que significa reparto del poder supremo, del legislativo, donde la primera obtiene una parte y la segunda se refugia en torno al rey y a la Administración. Ese reparto, sin embargo, no es más que una fase transitoria de equilibrio (pero de equilibrio social dentro del poder supremo, no entre los tres poderes) que en Francia dará paso inmediatamente a otra de monopolio político de la burguesía (152), cuyo símbolo son las constituciones de régimen especializado (153).

Cuando el constitucionalismo burgués alude a los "derechos" políticos, se expresa en términos colectivos, generales y no individuales (154), lo que les aleja de los derechos subjetivos privados: "La diferencia entre estas dos suertes de derechos -afirmará Sieyes- consiste en que los derechos naturales y civiles son aquellos para cuyo mantenimiento y desarrollo se ha formado la sociedad, mientras los derechos políticos se hallan integrados por aquellos otros por medio de los cuales el Estado se forma y se mantiene" (155). Unos radicaban en la separación de poderes que toda constitución debía establecer: el art.V de la Declaración de Derechos de Maryland afirmaba que "el derecho del pueblo a participar en el poder legislativo es la mejor garantía de la libertad y el fundamento de todo gobierno libre"; por su parte, en 1774 la Declaración del Primer Congreso Continental americano manifestaba: "El fundamento de la libertad inglesa y de todo Gobierno libre es el derecho del pueblo a participar en la Cámara legislativa”. Hegel, por su parte, lo expresó con su precisión característica: "Si se habla de constitución, de lo único de que se trata es de garantías objetivas, es decir, de las instituciones, los momentos que se limitan y condicionan de un modo orgánico. La libertad pública y el carácter hereditario del trono son pues garantías recíprocas, porque la libertad pública es la constitución racional y el carácter hereditario del príncipe es, como se ha señalado, un momento incluído en el concepto de la constitución" (156).

La libertad política no fue ningún descubrimiento del liberalismo, sino que, como observó Hobbes (157), ya existió en épocas anteriores: era la libertad de las clases dominantes, la expresión de su poder y su diminación. En cuanto a 
la libertad política, el constitucionalismo no pretendió más que institucionalizar el ascenso social de la burguesía, que se instrumentalizaba a través del sufragio censatario y se materializaba en el parlamento, en la cámara baja. Era el punto de inflexión en el que su peso económico-privado debía transferirse a lo público. Se trataba de la libertad de una clase, la libertad de la burguesía que reclamaba su cuota de poder, idea que fue bastante claramente expresada por Kant en uno de sus escritos más oscuros:

Sólo la capacidad de votar cualifica al ciudadano; pero tal capacidad presupone la independencia del que, en el pueblo, no quiere ser únicamente parte de la comunidad, sino también miembro de ella, es decir, quiere ser una parte de la comunidad que actua por su propio arbitrio junto con otros. Pero la última cualidad hace necesaria la distinción entre ciudadano activo y pasivo, aunque el concepto de este último parece estar en contradicción con la definición del concepto de ciudadano en general.

Los siguientes ejemplos pueden servir para resolver esta dificultad: el mozo que trabaja al servicio de un comerciante o un artesano; el sirviente (no el que está al servicio del Estado); el menor de edad; todas las mujeres y, en general, cualquiera que no puede conservar su existencia (su sustento y protección) por su propia actividad, sino que se ve forzado a ponerse a las órdenes de otros (salvo a las del Estado), carece de personalidad civil y su existencia es, por así decirlo, sólo de inherencia.

El leñador que empleo en mi propiedad rural, el herrero en la India, que va por las casas con su martillo, su yunque y su fuelle para trabajar en ellas el hierro, en comparación con el carpintero europeo o el herrero, que pueden poner públicamente en venta los productos de su trabajo como mercancías; el preceptor en comparación con el maestro de escuela; el censatario en comparación con el arrendador, etc., son únicamente peones de la comunidad, porque tienen que ser mandados o protegidos por otros individuos, por tanto, no poseen independencia civil.

No obstante, esta dependencia con respecto a la voluntad de otros y esta desigualdad no se oponen en modo alguno a su libertad e igualdad como hombres, que juntos constituyen un pueblo; antes bien, sólo atendiendo a sus condiciones puede este pueblo convertirse en Estado y entrar en una constitución civil. Pero en esta constitución no todos están cualificados con igual derecho para votar, es decir, para ser ciudadano y no simples componentes del Estado. Porque del hecho de que puedan exigir ser tratados por todos los demás como partes pasivas del Estado, según leyes de la libertad natural y la igualdad, no se infiere el derecho a actuar con respecto al Estado mismo, a organizarlo y a colaborar en la introducción de ciertas leyes, como miembros activos; sólo se infiere que, sea cual fuere el tipo de leyes positivas que ellos votan, no han de ser contrarias a las leyes naturales de la libertad y de la igualdad -correspondiente a ella- de todos en el pueblo de poder abrirse paso desde ese estado pasivo al activo (158).

La igualdad sólo existía en el ámbito civil: todos los propietarios son iguales, todos los arrendamientos se rigen por las mismas normas, etc. En lo político la igualdad no existe: cada clase obtiene la cuota de poder que alcanza según la correlación de fuerzas que se se establece en un momento determinado. 
Cuando la burguesía reclama libertad es porque hay un desplazamiento del centro de gravedad sociológico que le permite demandar mayores niveles de intervención pública frente a la aristocracia (159).

La innovación del pensamiento liberal fue la libertad civil, la libertad privada. El constitucionalismo fue el primero en desarrollar la libertad individual, la libertad doméstica, el libre y espontáneo funcionamiento del mercado. En las civilizaciones antiguas no hay más libertad que la libertad política, la libertad del ciudadano: la noción de una libertad civil del individuo particular distinto del ciudadano, es una noción ajena a tales civilizaciones (160). El individualismo burgués, el "apoliticismo" (161), es la preocupación máxima de los derechos humanos, de modo que hasta la expresión es de nueva creación, como decía Tocqueville: los antecesores sólo conocían el egoísmo, que es algo muy diferente (162).

El Discurso Preliminar dedica los treinta primeros párrafos a extenderse sobre los poderes legislativo y ejecutivo, y luego comienza así a referirse a la potestad jurisdiccional: "Hasta aquí quedan sentadas las bases en que reposa el suntuoso edificio de la libertad política de la Nación. El íntimo enlace, el recíproco apoyo que debe haber en toda la estructura de la Constitución, exige que la libertad civil de los españoles quede no menos afianzada en la ley fundamental del Estado, que lo está ya la libertad política de los ciudadanos. La conveniencia pública, la estabilidad de las instituciones sociales, no sólo pueden permitir, sino que exigen muchas veces que se suspenda o se disminuya el ejercicio de la libertad política de los individuos que forman la Nación. Pero la libertad civil es incompatible con ninguna restricción que no sea dirigida a determinada persona, en virtud de un juicio intentado y terminado según la ley promulgada con anterioridad. Así es que en un Estado libre puede haber personas que por circunstancias particulares no concurran mediata 0 inmediatamente a la formación de las leyes positivas; mas éstas no pueden conocer diferencia ninguna de condiciones ni de clase entre los individuos de este mismo Estado. La ley ha de ser una para todos, y en su aplicación no ha de haber acepción de personas" (163).

En el primer pensamiento constitucionalista, mientras lo privado es el ámbito de la libertad, de la autonomía de la voluntad, del contrato y del acuerdo, lo público queda singularizado por la violencia, la fuerza y la coacción con que se impone, en última instancia, el deber de obediencia. Esa distinción entre lo público (injerencia, fuerza, violencia) y lo doméstico (libertad, "independencia", "individualismo") desempeña un papel fundamental en todas las construcciones jurídicas de los primeros constituyentes (164). Dumoulin llamaba al Derecho Civil el Derecho de la libertad: "El contrato respira libertad", afirmaba; y Tocqueville opondrá abiertamente propiedad y autoridad (165). Una comprensión horizontal y no jerárquica de la separación de poderes, como la que se ha hecho tópica con Duguit (166), no rebasa aún el ámbito del Derecho privado, donde poder es sólo potestad, esto es, comisión, habilitación, mandato, capacidad de obrar o gestión de negocios ajenos. Pero en el ámbito político y público, el poder es autoridad, es jerarquía y obediencia de uno hacia otro (167). En el constitucionalismo hay una clara jerarquía tanto entre los poderes como entre lo público y lo privado. El Derecho público se construye en torno a las nociones romanistas de "imperium" y "auctoritas": según 
Montesquieu "nada da más fuerza a las leyes que la subordinación extremada de los ciudadanos a los magistrados" (168). Para Hobbes "el imperio es el poder y la administración es el acto de gobernar; por tanto, el poder es igual, en cierto modo, en cualquier clase de Estado" (169). Por una parte, identifica Hobbes "imperium" y poder, subrayando su vinculación con la capacidad coactiva, con la disposición de la fuerza, como rasgo peculiar y destacado del Estado, frente a otro tipo de funciones como las legislativas o administrativas; además, sostiene Hobbes que el poder no se modifica -no disminuye- sea cual fuere la forma de gobierno, porque en todas ellas es característico el monopolio de la capacidad de coerción.

Esta separación entre el Estado y la sociedad es acentuada al máximo por el pensamiento liberal primitivo, y permite acuñar el moderno concepto de representación: lo privado alude normalmente a la gestión directa de intereses propios y personales, en tanto que lo público es esencialmente vicarial, actua siempre por delegación o representación, gestionando intereses ajenos, los de la sociedad. La crítica de Sieyes contra los privilegios tuvo precisamente ese punto de arranque: los privilegios introducían una jerarquía dentro de la sociedad que sólo es admisible en las relaciones entre los mandatarios públicos y la nación; la llamó "supremacía legal". Esa superioridad, decía Sieyes, no es personal sino de las funciones: "En una sociedad sólo se necesitan ciudadanos que vivan y actuen bajo la protección de la ley y una autoridad encargada de velar y proteger. La única jerarquía necesaria, como ya dijimos, se establece entre los agentes de la soberanía; sólo en este caso se necesita un escalonamiento de poderes y se manifiestan las auténticas relaciones de inferior a superior, porque la máquina pública sólo puede funcionar gracias a esa relación" (170).

Los derechos y libertades se deben examinar en ese doble plano: en cuanto se contienen en las Declaraciones de Derechos, son textos metapositivos, expresión del Derecho Natural; en cuanto derechos individuales, constituyen materia de las leyes ordinarias: tampoco forman parte de la constitución, sino que tienen un nivel legislativo que protege la libre iniciativa de la sociedad frente a las injerencias del ejecutivo; formulados en forma negativa, nada ordenan sino que delimitan el ámbito de movimientos de los particulares. La ley positiva tiene esas dos vertientes: es un mandato del legislativo al ejecutivo, por una parte $y$, por la otra, tutela el ámbito de lo privado frente a la acción pública, de manera que cualquier pretensión sobre el ciudadano requiere previa ley y previa decisión jurisdiccional en su aplicación; es decir, impide la acción administrativa y habilita la judicial.

\subsection{El derecho de resistencia}

La superioridad de lo público significa, desde otro punto de vista, la obligación de obediencia de los ciudadanos, la reducción del "derecho" de resistencia a los supuestos de órdenes ilegítimas, bien por emanar de autoridad incompetente ("absque titulo"), bien por abuso de sus facultades ("ab exercitio") (171). La religión constituyó un factor fundamental de legitimación del Antiguo Régimen al difundir la obediencia como una obligación incondicional de los vasallos (172). 
El divorcio entre la autoridad terrenal y la divina comenzó con el absolutismo. La resistencia constituyó entonces un arma del papado contra los príncipes: la excomunión permitía a los creyentes desobedecer al rey porque su dominio pasaba a ser ilegítimo. A medida que se incubaba la doctrina de la soberanía y se imponía el absolutismo, los monarcas pretendieron desligarse de intermediarios: su título era de origen divino; respondían ante dios directamente de su administración, sin que entre ambos se interpusiera el pontífice (173). Bodino (174), Spinoza (175) y Hobbes (176) fueron enemigos declarados del "derecho" de resistencia, mientras los autores españoles de la época (jesuitas como Juan de Mariana (177)) son sus más vivos expositores, saliendo así en defensa de la autoridad papal.

El constitucionalismo tuvo que recurrir nuevamente al "derecho" de resistencia como argumento justificativo de la aparición de una nueva legitimidad. En Inglaterra, mientras los conservadores, por influencia de la iglesia anglicana, eludían el problema con la ficción de una abdicación, los "wighs" y Locke en primer término (178), volvían de nuevo al "derecho" de resistencia, derivado ahora tanto de la noción de una supralegalidad -los derechos y libertades ciudadanas (179)- como de la de unos poderes configurados como delegación o fiducia. Este "derecho", pues, forma parte integrante e indisoluble del nuevo sistema político revolucionario (180), fue taimadamente recordado por Montesquieu (181) y se incluyó en el art.2 de la Declaración de 1789 junto a otras piezas maestras tan trascendentales como la libertad, la propiedad y la seguridad.

Originariamente legitimaba el asalto al poder de la burguesía (182): al discutir sobre la declaración de derechos, el propio Mirabeau preconizaba no caer en el resentimiento hasta el extremo de "hacer menos una declaración de los derechos del hombre que una declaración de guerra a los tiranos" (183). En España se hizo una mención cuidadosa de la resistencia para justificar la guerra de la Independencia contra un ejército ocupante cuya presencia avalaba la autoridad legítimamente constituída en el momento:

La sublime y heroica insurrección a que ha recurrido la desventurada España para oponerse a la atroz opresión que se la preparaba, es uno de aquellos dolorosos y arriesgados remedios a que no puede acudirse con frecuencia sin aventurar la misma existencia política que por su medio se intenta conservar. Por tanto, la experiencia acredita, y aconseja la prudencia, que no se pierda jamás de vista cuanto conviene a la salud y bienestar de la Nación, no dejarla caer en el fatal olvido de sus derechos, del cual han tomado origen los males que la han conducido a las puertas de la muerte...

El juntar Cortes cada año es el único medio legal de asegurarse la observancia de la Constitución sin convulsiones, sin desacato a la autoridad y sin recurrir a las medidas violentas que son precisas y aún inevitables cuando los males y vicios en la Administración llegan a tomar cuerpo y envejecerse (184).

Se trataba, nada menos, que del acto fundacional del nuevo régimen político. El Tercer Estado lo consignó en los cuadernos de los Estados Generales, para justificar el carácter constituyente de la Asamblea Nacional. El "derecho" de resistencia era esencialmente ajurídico, estaba fuera del ordenamiento jurídico precisamente porque era la máxima expresión de las garantías. En última 
instancia, los derechos deben estar asegurados por "poderes exteriores", decía Jellinek y, en la época, figuras como la milicia nacional en Francia o España, o el derecho al porte de armas, en Estados Unidos, eran manifestaciones del "derecho" de resistencia.

Pero a medida que la energía revolucionaria de la burguesía se agota, este "derecho" de resistencia se va difuminando en sus perfiles más peligrosos (tiranicidio del art.27 o derecho insurreccional del art.35, ambos de la Declaración jacobina) legalizándose sus restos (derecho de petición, reunión, etc.). El "derecho" de resistencia se desecha y olvida rápidamente para poder disponer de libertad de movimientos. Una vez en el poder, la burguesía temió que ese mismo "derecho" pudiera ser invocado por sus oponentes y arrojó un pesado fardo sobre los propios fundamentos de su régimen político, de su "poder de dominación" como poder "irresistible" que diría Jellinek. La legitimidad daba paso a la legalidad, el Derecho natural al Derecho positivo, el "ius" a la "lex". El proceso consistió esencialmente en:

- la "legalización" de los derechos y libertades, la conversión de la constitución en una ley material con su parte dogmática y la intervención judicial subsiguiente

- la integración de un repertorio de manifestaciones concretas del derecho de resistencia en la constitución y en la legislación ordinaria

- la criminalización del resto, la transformación del "derecho" de resistencia en delito de resistencia, desacato y desobediencia (185)

- cerrando el ciclo, la desaparición del derecho de resistencia como tal derecho, es decir, el cierre del principio de legalidad ("no hay legitimidad fuera de la legalidad').

Quedaba muy lejos -exactamente en las antípodas- el art.29 de la Declaración de Derechos de Robespierre, donde decía que "someter a formas legales la resistencia a la opresión es el último refinamiento de la tiranía”. Todo el proceso posterior, pues, no fue más que un proceso de refinamiento de esa tiranía de clase, una incorporación dosificada al sistema de legalidad de determinados "derechos", antes calificados de "ilegislables", a costa de eliminar el fundamental, el de resistencia, de predicar, como dijo lhering, la "fuga ante la injusticia" (186).

Esta efímera vigencia de la resistencia legítima dentro del sistema político burgués no invalida, sino todo lo contrario, la superioridad de la autoridad pública respecto a los particulares; la sujeta a límites temporales: si la función pública no está patrimonializada sino destinada a servir a los ciudadanos, estos pueden revocar a aquellas autoridades que no cumplan con su cometido o lo hagan de forma que vulnere los "derechos" inalienables e imprescriptibles de los ciudadanos. El "derecho" de resistencia se suma, pues, al sufragio y está en la génesis misma del concepto de responsabilidad política, otra de las piezas claves del constitucionalismo (187). La resistencia ciudadana es la contrapartida de su deber de obediencia: los funcionarios se situan por encima de la nación pero están a su servicio y, por tanto ésta "tiene derecho de pedir cuentas de su administración” (art.15 de la Declaración de Derechos de 1789). 


\subsection{El gobierno mixto: separación de poderes y separación de clases sociales (la racionalidad politica)}

Entramos finalmente en el aspecto político y clasista de la separación de poderes, en su racionalidad política, manifestada tanto en los distintos tipos de constituciones como en la separación de órganos que cada constitución determina.

Es evidente que cada constitución es reflejo del (des)equilibrio que toda sociedad manifiesta. "El constitucionalismo -escribe el profesor Nieto- expresa el acceso al poder de una clase -eufemísticamente llamada 'pueblo'- que acota en su beneficio una determinada área del mismo: el Parlamento, y su producto por antonomasia: la ley... La ley ya no es sólo la razón, es la voluntad del pueblo y el Parlamento es el instrumento que garantiza a una clase eufemismos ideológicos aparte- la penetración en las estructuras del Estado, antes acotado en beneficio exclusivo del Monarca y la aristocracia" (188). De las cartas a las constituciones especializadas, hay todo un continuo constitucional expresivo de ese (des)equilibrio sociológico, que va desde la reacción aristocrática con veleidades pseudo-constitucionalistas, hasta la concentración de poderes más absoluta en manos de la burguesía, pasando por los modelos de equilibrio que reflejan las constituciones mixtas.

Los órganos constitucionales expresan también los intereses de otros tantos estamentos sociales: la cámara baja a la burguesía, la alta a la nobleza, etc. "Cada poder -escribe Ruiz del Castillo- organiza la defensa de una prerrogativa de clase social... Se trata del principio social de la división de clases sobre el principio exclusivamente político de la división de poderes" (189). Unos -la cámara baja- representan a terceros, y los demás se representan a sí mismos, con excepción del poder judicial, que no representa a nadie, precisamente porque no forma parte del poder legislativo, sino que está supeditado a él y, por ello mismo, es "de alguna forma nulo" (190): no puede tomar ninguna "resolución activa", afirma Hamilton, "no poseee fuerza ni voluntad, sino únicamente discernimiento, y que ha de apoyarse en definitiva en la ayuda del brazo ejecutivo para tengan eficacia sus fallos... Los tribunales tienen que declarar el significado de las leyes; y si estuviesen dispuestos a poner en ejercicio la voluntad en vez del juicio, la consecuencia sería la misma de sustituir su deseo al del cuerpo legislativo. Pero si algo prueba esta observación, sería que no debiera haber jueces independientes de ese cuerpo" (191). Es esta falta de independencia de los poderes lo que demuestra que subsiste la unidad del Estado "pese" a la separación de poderes, por cuanto no hay más que una sola voluntad, la del poder legislativo; los otros dos poderes carecen de voluntad propia: su función es hacer operativa la voluntad legislativa.

El problema de la unidad del Estado hay que plantearla, en el contexto de la época, dentro de la concepción antropomórfica que del mismo se tenía entonces; y más en concreto hay que relacionarlo con la cuestión de la "voluntad" del Estado, de su dirección política. Por tanto, una vez más, me parecen muy alejadas del constitucionalismo originario las afirmaciones que hiciera Duguit: 
Los poderes se conciben como los elementos mismos de la voluntad del Estado tomada en sí, y son cada uno soberanos, aunque no haya más que una sola e indivisible soberanía...

Son los elementos constitutivos de la voluntad nacional soberana, en tanto que se encuentra fraccionada... La voluntad nacional siendo soberana, cada uno de esos elementos de soberanía está delegado por representación a un órgano y cada órgano ejerce una función diferente.

Finalmente, un poder es un elemento fraccionado de la soberanía incorporado a un órgano, el cual ejerce una función correspondiente. La soberanía, siendo indivisible, cada uno de esos poderes es soberano, y siendo la soberanía una, aunque haya varios poderes, no hay más que una soberanía (192).

Nada de esto es imputable al primer constitucionalismo: ni se fracciona la soberanía ni se resiente la unidad del Estado con la separación de poderes, porque no hay más que una voluntad en el Estado que es la ley, la resolución del poder legislativo. Los predecesores de Locke y Montesquieu no habían podido superar la contradicción que el gobierno mixto implicaba con la unidad del Estado y el principio de soberanía (193). El gobierno mixto era incompatible con el principio de soberanía y la unidad del Estado porque en él no hay unidad de la voluntad, ni unidad del poder ejecutivo; los poderes no están concebidos formalmente: no se oponen a la representación nacional, sino que pueden estatuir positivamente y llevar a efecto sus resoluciones con sus propias fuerzas. Era también incompatible con otra clave esencial del constitucionalismo de aquella época: con el concepto formal de constitución y la neutralidad del Estado, ya que introduce órganos (el rey y la cámara alta) ocupados por sectores sociales que o bien gestionan sus propios intereses, o bien gestionan los asuntos públicos en beneficio particular y no de la nación; no elegidos, además, por la nación y no responsables ante ella. Ni el rey ni las cámaras altas expresan la voluntad general ni atienden al bien común: sus actos no pueden ser leyes ni por su origen ni por su destino y, sin embargo, forman parte del poder legislativo con facultad de estatuir.

Para Locke y Montesquieu, por contra, los poderes no eran más que formas de manifestarse la soberanía; Rousseau -y Kant después de él- asimiló la soberanía a la voluntad general, de modo que podía transferirse el poder, pero no la voluntad; puede enajenarse la forma de ejecutar, pero no el contenido de la ejecución ordenado por la voluntad general. Constant fue el primero en volver a la tesis preliberal, pretendiendo introducir en la teoría una contradicción que es sólo fruto de un sofisma que él mismo injerta deliberadamente. En efecto, Constant parte de considerar los poderes materialmente repartidos, y no formalmente: por tanto -afirma- son poderes limitados y finitos que, sumados no alcanzan la soberanía que es por definición ilimitada; la suma de partes finitas no da un total infinito, y de aquí Constant deduce "matemáticamente" que la soberanía es limitada (194), de donde pasa a estudiar el problema del reparto de competencias (195) que en tales circunstancias, lógicamente, se convierte en la clave de todo. De aquí que las filosóficas discusiones desarrolladas acerca de la soberanía y otras cuestiones conexas como la separación de poderes, se transforman en Constant en algo mucho más sencillo y prosaico, de "Derecho Procesal": distribuir las funciones, repartirse las atribuciones públicas. Pero no podemos pasar por alto que las 
ideas de Constant en este punto tienen muy poco que ver con los clásicos del liberalismo, por más difundidas que hoy estén, mientras que, según Hegel "estas dos determinaciones, que los asuntos y los poderes particulares del estado no son fijos e independientes ni por sí ni en la voluntad particular de los individuos, sino que tienen su raíz última en la unidad del estado como en su propia identidad simple, constituyen la soberanía del estado" (196). No obstante, en efecto, pueden las constituciones monárquicas mixtas entrar en contradicción con el principio de soberanía; pero solamente en esas circunstancias: en tanto que la persona del rey es "sagrada e inviolable" y no electiva, y en tanto que dicho tipo de constituciones integran en su seno un sistema de gobierno mixto y por las mismas razones por las que también contradicen la "neutralidad" del Estado.

De la tesis de que el legislativo expresa la única voluntad del Estado se desprende también que sólo el legislativo es un poder independiente, como expusiera Rousseau:

La voluntad dominante del Príncipe no es, o no debe, más que la voluntad general o la ley, su fuerza no es más que la fuerza pública concentrada en él, y tan pronto como quiere sacar de sí mismo algún acto absoluto e independiente, la trabazón de todo comienza a relajarse. Si finalmente ocurriera que el Príncipe tiene una voluntad particular más activa que la del soberano, y que para obedecer a esta voluntad particular usa de la fuerza pública que está en sus manos, de suerte que hay por así decir, dos soberanos, uno de derecho y otro de hecho, al instante la unión social se desvanecería, y el cuerpo político quedaría disuelto...

Así la voluntad del pueblo y la voluntad del príncipe y la fuerza pública del Estado y la fuerza particular del gobierno, todo responde al mismo móvil, todos los resortes de la máquina están en la misma mano, todo marcha hacia el mismo objetivo, y no hay movimientos opuestos que se destruyan entre sí, y no se puede imaginar ninguna clase de constitución en la que un esfuerzo menor produzca una acción más considerable (197).

No hay voluntad en el ejecutivo ni en el judicial distinta de la voluntad de la ley. "El poder legislativo -escribirá Kant- sólo puede corresponder a la voluntad unida del pueblo... De ahí que sólo la voluntad concordante y unida de todos, en la medida en que deciden lo mismo cada uno sobre todos y todos sobre cada uno, por consiguiente, sólo la voluntad popular universalmente unida puede ser legisladora" (198). La voluntad no se fracciona y, en consecuencia, tampoco la soberanía, porque los poderes no son soberanos cada uno de ellos, ni participan de la soberanía en forma alguna: sólo el legislativo determina la voluntad del Estado, sólo el legislativo es, por tanto, libre, mientras que los demás poderes aparecen esclavizados. El Derecho en aquel primer constitucionalismo se reduce a la ley, expresión única y unívoca de una voluntad autodeterminada que no pede resultar condicionada o mediatizada por otras instancias ni otros poderes.

Para cerrar el círculo, no puede pasar desapercibido que, precisamente quien determina la voluntad pública, la voluntad del Estado y, en consecuencia, su unidad, es el poder que representa a la sociedad, el poder que está más próximo a la sociedad, a lo privado que a lo público. De aquí se sigue, sin 
mayores dificultades, el servilismo de lo público respecto a lo privado, la superioridad del interés privado sobre el público, si es que puede hablarse de interés público en la época, de objetivos o fines del Estado como tal, al margen de los de los ciudadanos.

Otra forma de concebir la separación de poderes redundaría en confundirla con el gobierno mixto. Pero éste, a diferencia de aquella, tiene un alcance mucho más reducido: alude a una forma de gobierno, mientras que la separación de poderes es el mismo gobierno constitucional, o Estado constitucional, por emplear un término actual. El gobierno mixto, por contra, es pre-constitucional y pre-liberal; se remonta a Polibio y el auge adquirido con la revolución inglesa (199) denota la pujanza de la burguesía y el esfuerzo por articular en el seno del Antiguo Régimen a una clase social emergente que no tenía cabida en las viejas instituciones (200). La separación de poderes puede integrar al gobierno mixto como forma posible de constitución; pero el gobierno mixto, por sí mismo, no articuló nunca la separación de poderes. La separación de poderes es compatible con la soberanía; el gobierno mixto no: implica una soberanía compartida.

Ciertamente es ilusorio el intento de deslindar perfectamente ambas instituciones que no son incompatibles, sino que se suceden -y superan- una a otra (201). En realidad una constitución monárquica mixta que procede a un reparto material de competencias no es más que la integración del gobierno mixto en un sistema de separación de poderes, lo que fue duramente criticado por los partidarios de las constituciones especializadas (202). Pero enmedio hay justamente un abismo, la constitución, algo que a su vez también deriva del pacto social pero lo supera. Mientras los partidarios del gobierno mixto aluden al pacto social, los de la separación de poderes tienen la constitución como punto de referencia y obra humana artificial y modificable. El gobierno mixto es objeto de la teoría política y carece de las referencias jurídicas que aparecen en la separación de poderes. Su objetivo es la integración de los tres segmentos sociales opuestos que bullían entonces en la sociedad, mientras que la separación de poderes trata de repartir y organizar el Estado entre una o varias clases sociales. En el gobierno mixto subyace, ante todo, un reparto material de las funciones públicas a determinadas estamentos sociales: el rey, la aristocracia y la nobleza, fuerzas sociales que pueden identificarse en determinadas instituciones: los "poderes" son entonces independientes, y lo que se pretende precisamente es articularlos (203). En la separación de poderes, la actividad del Estado comienza a concebirse de manera formal: lo que adquiere relieve no es tanto el hacer como la diferenciación entre el ordenar hacer y el propio hacer. Es este concepto formal el que permite desarrollar el concepto abstracto de ley y, por ende, el de constitución. En la separación de poderes es posible el "gobierno de asamblea", pero eso sólo significa que el legislativo resuelve sobre materias administrativas, mientras que su ejecución corresponde siempre al poder ejecutivo porque, como veremos, la fuerza coactiva del Estado no se divide. Por tanto, el gobierno mixto divide la voluntad del Estado -y con ella la soberanía y el Estado mismoy divide también el poder ejecutivo, nada de lo cual sucede con la separación de poderes. 
El sistema constitucional mixto monárquico puede chocar con el principio de representación y, por derivación, con el de soberanía (204) cuando hay un reparto material de competencias porque, en esos casos, lo que hace es pretender integrar el gobierno mixto en un sistema de separación de poderes. En efecto, cuando la burguesía revolucionaria habla de nación, comprende una parte sólo de todos los habitantes: de todos menos del rey (205). Este no es un ciudadano, salvo que abdique de la corona (206). Hay aquí latente una contraposición trascendental que nunca pudieron resolver los monárquicos partidarios del sistema constitucional mixto sin renunciar al principio de soberanía. Nación en Sieyes es un concepto negativo; es lo que queda después de excluir a los sectores privilegiados de la sociedad; es el tercer estado, el estado llano: "Un cuerpo de asociados que viven bajo una ley común y representados por la misma legislatura" (207). Pero el rey (y la nobleza, en su caso) no están representados por el parlamento, sino que tienen su propia representación y su propia ley, "lex privata", prerrogativa o privilegio, hasta el punto de que Paine llegó a afirmar que "la Corona es la parte tiránica de la Constitución de Inglaterra" (208).

La Constitución española de 1812 se refería a la titularidad de la soberanía en el art.3, mientras que en el 15 habla de su ejercicio; titularidad única de la soberanía y ejercicio compartido de la potestad suprema de elaborar las leyes por las Cortes y el rey: tal es el sistema contradictorio de 1812 y de todas las constituciones monárquicas mixtas. La soberanía nacional deviene así vacía de significado real, especialmente teniendo en cuenta que:

- existe un reparto material y limitado de competencias, quedando en manos del rey funciones del Estado fuera del alcance fiscalizador de las Cortes

- la persona del rey es sagrada (art.168), está por encima de toda legislación positiva, incluída la constitución y, por lo mismo, dispone de competencias que son verdaderas prerrogativas, esto es, anteriores e independientes de la constitución, consustanciales a su carácter y posición

- las Cortes, a diferencia de la Asamblea de 1791, no era un cuerpo permanente (art.106).

Es aquí precisamente donde se aprecia la diferencia radical entre Locke y Montesquieu, por una parte, y Rousseau, e incluso Sieyes, de la otra. La monarquía constitucional, en última instancia, resultaba una incongruencia jurídica, una componenda de difícil conciliación, una contradicción en los términos, ya que las críticas vertidas sobre el bicameralismo se podían extender a la propia corona, ajena a la soberanía nacional y sostenida únicamente, en palabras de Constant, por "recuerdos y tradiciones religiosas" (209). En referencia a la Constitución inglesa, escribió Sieyes: "Los caracteres de una buena representación son lo más esencial que hay para formar una buena legislatura. ¿Se ha sacado de los buenos principios la idea de separar el poder legislativo en tres partes, una sola de las cuales se reputa que habla en nombre de la nación? Si los señores y el rey no son representantes de la nación no son nada en el poder legislativo pues sólo la nación puede querer por sí misma y, por consiguiente, crearse leyes. Todo lo que entra en el cuerpo legislativo no es competente a votar por los pueblos sino en tanto que está encargado de su procuración. Pero ¿dónde está la procuración cuando no hay 
elección libre y general?" (210). Ahora bien, todas las críticas contra la constitución inglesa son reproducibles contra la francesa de 1791 o la española de 1812 en cuanto introduce un gobierno mixto en la constitución; sólo cambia el número de piezas del gobierno mixto, que si en las islas es tres, en los constituyentes franceses se redujo a dos.

Un reparto material de las funciones del Estado, calificado además de prerrogativa y a disposición de órganos no electivos, implica fragmentar la voluntad del Estado. Esos órganos están capacitados para disponer, actuando además en su propio beneficio y sin control posible de la cámara baja, no sujetos a fiscalización superior. Cada órgano dispone de un área autónoma de actuación; sí es entonces independiente, sí está fragmentada la soberanía. Hay, pues, dos soberanos, o incluso tres, si se añade una segunda cámara. En Inglaterra, como afirman García de Enterría y T.R.Fernández, consecuencia del sistema constitucional mixto, es que el rey y el parlamento "no son elementos parciales de una realidad superior, el Estado, según las ideas más o menos místicas del monarquismo continental, sino que tienen sustantividad independiente, no interiorizados en ninguna pretendida unidad superior" (211).

De aquí los problemas de los partidarios del gobierno mixto, como John Adams, para compatibilizarlo con el principio de soberanía. En el gobierno mixto hay, en definitiva, dos voluntades (212) que no tienen porqué coincidir y, de hecho, no coincidieron pues la aristocracia, en Francia como en España, no admitió pacíficamente el nuevo régimen y se enfrentó a él por todos los medios que tuvo a su alcance. La viabilidad del sistema mixto implica el acuerdo para ejercer en común las mismas competencias, exige una política común que no se dió en ninguno de los dos países.

El sistema mixto, por tanto, es compatible con la separación de poderes, pero no con el principio de representación, de ejercicio de la soberanía, porque si ésta es única, inalienable, etc., sólo puede ser representada por un cuerpo único, o por dos siempre que todos ellos sean electos y representativos de la voluntad general.

La soberanía, el poder constituyente, son poderes jurídicos, no reales sino "inorgánicos" en el sentido de Lasalle. Un sólo titular de la soberanía y un ejercicio compartido de la misma por dos entes de origen radicalmente diverso es una superación puramente formal del dualismo escolástico medieval (213). El problema radica, pues, no solamente en el segundo nivel (poder legislativo), ni en su partición o unicidad, sino en que simultáneamente el rey sea poder legislativo y no electo. Roussesau admitió la monarquía, e incluso la monarquía hereditaria; pero esto en su esquema sólo era posible en el tercer nivel, es decir, si el rey era sólo poder ejecutivo, si se trataba de constituciones especializadas. En las mixtas, el principio de soberanía nacional sólo es compatible con la república, como en los Estados Unidos, porque si el presidente es poder legislativo debe ser representante y por tanto elegido, no hereditario.

En el gobierno mixto la burguesía pretende, principalmente, controlar la exacción de tributos que debe pagar, mientras la nobleza goza de exención (214); en la separación de poderes está en condiciones de controlar todas las actividades públicas. En el gobierno mixto cada órgano defiende los intereses 
de su clase; en la separación de poderes hay por lo menos un órgano, la cámara baja, que representa a toda la nación. El Discurso Preliminar justifica del modo siguiente las razones por las que, apartándose del llamamiento de la Junta Central, no procede a una convocatoria de Cortes por "brazos":

Los magnates y los prelados dueños de tierras con jurisdicción omnímoda, con autoridad de levantar en ellas huestes y contribuciones para acudir al Rey con el servicio de la guerra, claro está que no podían menos de asistir a los Congresos nacionales, en donde se habían de ventilar negocios graves, y que podían con mucha facilidad perjudicar a sus intereses y privilegios. Iban a ellos, no por elección ni en representación de ninguna clase, sino como defensores de sus fueros, y partes directa y personalmente interesadas en su conservación. Así es que no hay un solo vestigio en la historia que indique siquiera que los grandes y prelados eran elegidos para ir a las Cortes. O asistían por derecho personal o llamados por el Rey: y muchos de ellos, las más veces, como en Castilla, más bien en calidad de consejeros que a deliberar. Jamás usaron el nombre de procuradores, porque la Nación no les daba ningunos poderes... No teniendo ya en el día los grandes, títulos, prelados, etc., derechos ni privilegios exclusivos que los pongan fuera de la comunidad de sus conciudadanos, ni les de intereses diferentes que los del procumunal de la Nación, faltaba la causa que en juicio de aquella dio origen a los brazos...

La razón más poderosa, la que ha tenido para la Comisión una fuerza irresistible, es que los brazos, que las Cámaras o cualquiera otra separación de los diputados en Estamentos, provocaría la más espantosa desunión, fomentaría los intereses de Cuerpos, excitaría celos y rivalidades...

Así como se han suprimido los brazos por incompatibles con un buen sistema de elecciones, o sea representativo, por la misma razón se ha omitido dar diputados a las ciudades de voto en Cortes: pues habiendo sido éstas la verdadera representación nacional, quedan hoy incorporados en la masa general de la población, única base que se ha tomado para en adelante (215).

El gobierno mixto expresa -mejor aún que la separación de poderes- las cuotas de poder obtenidas por las clases sociales, el reparto entre ellas de las funciones del Estado. La separación de poderes puede ser eso, pero siempre es mucho más que eso simplemente. El constitucionalismo mixto -solo una forma posible de separación de poderes- al repartir el poder legislativo entre las cámaras y el rey, lo que pretende es el acuerdo entre las diversas clases sociales de la época. De ahí que Hegel calificara la función del legislativo y de la misma constitución como una labor esencial de "mediación" (216). Las constituciones mixtas, o son una oferta de acuerdo entre las clases antes de la revolución, o son fruto de un equilibrio entre ellas después de la revolución. Cuando se habla, por tanto, de balance o equilibrio en alusión a la separación de poderes, no se trata de un balance ni equilibrio entre los tres poderes, sino de un balance y equilibrio dentro del poder legislativo, expresivo de la correlación de fuerzas entre las clases sociales. No se trata de un equilibrio jurídico sino político. El balance desaparecía si los órganos diversos del poder legislativo actuaban al unísono; para evitarlo era imprescindible que esos órganos representaran a otras tantas clases sociales, de modo que la minoría (la aristocracia) no fuese oprimida por la mayoría (la burguesía y el conjunto del 
tercer estado) (217). No podía existir equilibrio constitucional si existía desequilibrio político: la inestabilidad constitucional francesa no es imputable a la separación de poderes, como pretende Carré de Malberg (218), sino a las vicisitudes de la lucha de clases.

La constitución mixta es la expresión jurídica de una determinada idea de "pacto social", una proposición de equilibrio que partió de la burguesía, y para cuya duración no bastaba sólo el acuerdo inicial, sino que exigía una transacción continua. Si no perduró no fue por sus defectos intrínsecos, ni por su mala formulación, sino porque toda situación de estabilidad social y política tiene un ámbito reducido de vigencia que deja paso al desequilibrio y al conflicto (219). Superada la propuesta de acuerdo interclasista en Francia por la realidad revolucionaria, quedó el mito alentado por un doctrinarismo conformista, quedó la superestructura jurídico-formal operando en el vacío, como cobertura ideológica de realidades políticas bien distintas.

\section{La unidad del poder ejecutivo y su monopolio de la fuerza 6.1 La supuesta limitación o autolimitación del poder del Estado}

No se encuentra en las fuentes nada (220) que de motivo para pensar en ninguna forma de limitación ni autolimitación del poder del Estado, corrientemente asociados a la separación de poderes (221). No solamente en las fuentes no se encuentran tales términos, sino que tampoco están los conceptos, ni siquiera apuntados. Más bien se advierte todo lo contrario porque, en efecto, tratar de extraer de la separación de poderes una limitación del poder del Estado es confundir en el término poder la competencia con la fuerza, con la "vis" física, y si no siempre se reparten las competencias mucho menos se reparte la fuerza, la capacidad coactiva del Estado (222).

Ya hemos visto que, según Montesquieu, el despotismo se diferencia de la monarquía moderada en que allí la obediencia carece de límites, debe ser total, que no existe posibilidad de resistencia de la sociedad frente al poder público. El "derecho" de resistencia es, pues, un límite indudablemente en ese sentido. Pero nada en esencia cambia en ambos sistemas políticos, afirma también Montesquieu, porque "aunque la manera de obedecer sea diferente en estos dos Gobiernos, el poder es, sin embargo, igual" (223). El poder, en consecuencia, ni se limita ni se reduce por la separación de poderes; lo que cambia es la forma en que se obedece. Idéntica es la concepción de Rousseau al respecto: "La fuerza total del gobierno, por ser la del Estado, no varía en absoluto... Como el uso de la fuerza depende del grado de la voluntad, y como la fuerza absoluta del gobierno no varía, se deduce que el más activo de los gobierno es el de uno solo" (224).

La ideología de la separación de poderes, privada de su vertiente históricopolítica y ceñida a un puro esquema jurídico, no nos explica qué es exactamente lo que se separa o divide en el poder. Se reparten las competencias y se dividen las funciones -se repite tautológicamente- pero ¿y la autoridad? ¿y la fuerza? Se interpreta muy frecuentemente (225) que la separación de poderes significa también separación del poder "stricto sensu", de la fuerza, de la capacidad coactiva del Estado y, además, que esto es cabalmente lo que hizo de la separación de poderes una garantía de la libertad 
de los ciudadanos. Se asocia separación de poderes a limitación y autolimitación del poder del Estado, a una cierta idea de los "balances y contrapesos" que recíprocamente frenaría a unos poderes con otros, de donde el ciudadano resultaría protegido, pudiendo acudir a unos poderes en contra de otros. Este planteamiento deriva de la vieja dicotomía -libertaria más que liberal- entre el poder y la libertad: si uno aumenta la otra disminuye, y viciversa. Si el poder del Estado fuese ilimitado -se afirma- no habría libertad, como si ésta comenzara sólo allá donde no alcanza el poder el Estado. Nunca se insistirá bastante en que todos estos tópicos son ajenos al liberalismo burgués de la época revolucionaria, cuya riqueza ideológica es infinitamente mayor que todo ese cúmulo de simplezas (226): no estaba fuera del poder sino dentro de uno de los poderes. Y en cuanto a la otra libertad, la libertad política, se trataba de un concepto claramente clasista: no era la libertad de todos, sino la de los propietarios, asegurada por la separación de poderes y la representación 0 , en otras palabras, del sufragio. Esta libertad pública no es asimilable a los derechos subjetivos técnicamente hablando, no tiene nada que ver con ellos. No puede tomarse literalmente una extrapolación del Derecho privado porque las libertades públicas hay que analizarlas políticamente.

El informe de Lally-Tollendal lo explicó con nitidez al afirmar que el poder legislativo era "divisible por naturaleza", a diferencia del ejecutivo, esencialmente indivisible (227): la fuerza, la capacidad coercitiva del Estado no puede dividirse, sino que, por el contrario, se centraliza en un mismo órgano. Rousseau decía que el poder ejecutivo no era más que la fuerza aplicada a la ley (228) y era esto lo que le hacía "esencialmente indivisible". También Hamilton subrayó las excelencias de la Constitución estadounidense al crear un poder ejecutivo unificado, lo que le da mucha energía "sobre todo cuando el poder se encuentra en unas solas manos" (229). Habla Hamilton del poder ejecutivo como el poder por antonomasia y propugna su concentración en unas mismas manos.

El poder, pues, tiene una connotación de fuerza, de coacción, de violencia, que también es una nota consustancial al Derecho precisamente porque no existe ese "bien común" al que va destinada la ley. Los partidarios de las clases sociales (Locke, Montesquieu) refuerzan por eso mismo el ejecutivo, la fuerza, mientras que los teóricos del "bien común" (Rousseau, Paine) lo reducen a su mínima expresión, a su función básica de asegurar el orden público, mientras que otro tipo de atribuciones administrativas pasan a ser competencia del propio legislativo ("gobierno de asamblea") o de los entes gubernativos locales. Pero en ningún caso la separación de poderes implicaba una división de la capacidad coercitiva del Estado. En última instancia, el Estado se distingue precisamente por esa capacidad coercitiva, y dividir la fuerza es destruirla ("divide et impera"). Lo que se reparten son las competencias entre autoridades distintas que quedan así jurídicamente habilitadas para funcionar, pero no el poder del Estado.

Cuando los primeros liberales se referían a la limitación del poder, se referían al absolutismo y lo que criticaban era que el mismo órgano que promulgaba las leyes pudiera ejecutarlas $y$, por tanto, hacer excepciones $e$ incurrir en desigualdades. La crítica iba dirigida a la concentración de poderes, a la ocupación de cargos públicos con carácter vitalicio, así como a su 
patrimonalización, esto es, al empleo de funciones públicas en provecho privado. También hay referencias a la limitación constitucional del poder, pero en los clásicos se trata fundamentalmente de los límites al poder legislativo como poder supremo, y se ciñe al veto y a su división en dos cámaras colegisladoras. Por supuesto hay limitaciones que se desprenden también de la propia configuración de los poderes, tales como el reparto material y concreto de competencias, pero esto es tan consustancial como secundario en determinados modelos de separación de poderes. Ya ha quedado expuesto, sin embargo, que en virtud de las primeras regulaciones de los conflictos de atribuciones, no había posibilidad de impedir la extralimitación de competencias del legislativo, salvo el veto. Pero éste es una facultad del rey en tanto que poder legislativo: defiende su parte en este poder y no al poder ejecutivo como tal, mientras que eran inconcebibles las invasiones de competencias de los otros poderes sobre el legislativo, ya que constituían otros tantos supuestos de prevaricación. Otros límites evidentes, a los que ya me he referido, son los que dimanan del "derecho" de resistencia que disponen los ciudadanos frente a las autoridades públicas cuando se violan las Declaraciones de Derechos o se utilizan torticeramente las facultades y competencias. O la propia separación entre el Estado y la sociedad, delimitando la ley el ámbito de libertad de ésta, que se encontraba al abrigo de la intervención pública, salvo resolución judicial que la autorizara.

Pero nunca se puso en cuestión la soberanía misma como poder supremo e ilimitado por definición, ni tampoco el poder del Estado entendido como capacidad coactiva que ni se dividía, ni disminuía, ni menoscababa lo más mínimo.

Por más separaciones y divisiones que se lleven a cabo, todo reconduce a la unidad del Estado y a la integridad de su fuerza coactiva. La afirmación de Montesquieu de que "el poder frene al poder" hay que situarla en este marco: no de que un poder frene a otro poder, pues colocaría a los poderes en el mismo plano constitucional, situados al mismo nivel y no supeditados al legislativo. Se trata precisamente de las limitaciones a la supremacía del poder legislativo, y más concretamente Montesquieu lo relaciona con la constitución mixta que él propugna. Se refiere a la división interna del poder legislativo en tres "potencias" expresivas de otras tantas clases sociales. Es, pues, el sistema de gobierno mixto dentro de la separación de poderes, la cohabitación del rey, la aristocracia y la burguesía dentro de la suprema potestad del Estado, dentro del poder legislativo. Son las clases y no los poderes los que tienen que equilibrarse:

Hay siempre en los Estados -decía Montesquieu- personas distinguidas por su nacimiento, sus riquezas o sus honores que si estuvieran confundidas con el pueblo y no tuvieran más que un voto como los demás la libertad común sería esclavitud para ellas y no tendrían ningún interés en defenderla, ya que la mayor parte de las resoluciones irían en contra suya. La parte que tomen en la legislación debe ser, pues, proporcionado a las demás ventajas que poseen en el Estado, lo cual ocurrirá si forman un cuerpo que tenga derecho a oponerse a las tentativas del pueblo, de igual forma que el pueblo tiene derecho a oponerse a las suyas. 
De este modo, el poder legislativo se confiará al cuerpo de nobles y al cuerpo que se escoja para representar al pueblo; cada uno de ellos se reunirá en asambleas y deliberará con independencia del otro, y ambos tendrán miras e intereses separados.

De los tres poderes que hemos hablado, el de juzgar es en ciero modo, nulo. No quedan más que dos que necesiten de un poder moderador para atemperarlos. La parte del cuerpo legislativo compuesta por nobles es muy propia para ello (230).

El pasaje es realmente revelador, pues demuestra cómo Montesquieu pasa del lenguaje jurídico al político, y viciversa, y que es precisamente la "anulación" de uno de los poderes lo que permite ese tránsito. Afirma por segunda vez que el poder judicial es "en cierto modo nulo": la otra lo hace tras recomendar que los jueces ejerzan sus funciones temporalmente, a través del jurado y del sufragio.

Pero es llamativa, sobre todo, la separación de clases sociales con "miras e intereses separados"que no pueden confundirse en una masa uniforme e igual de ciudadanos, sino que deben asumir "partes proporcionadas" en el poder. Propone situar a la nobleza -su clase- como árbritro, como "poder moderador", entre la realeza y la burguesía a través de su instalación en el poder legislativo, que se debe dividir, reservando para ella una de las cámaras.

Se trata, una vez más, de un problema clasista que nada tiene que ver con las libertades y derechos individuales; se trata de evitar que el poder se concentre en unas mismas manos, en una misma clase que la capacitaría para oprimir a las demás; se trata de la libertad política de un ciudadano -si se quiere- en tanto que integrante de una clase, de defensa de las posiciones políticas de cada clase en el Estado.

Quienes hablan de los frenos, balances y contrapesos entre los poderes, no dan cuenta de cómo y por qué medios se procede a tales equilibrios. Es imposible que los poderes ejecutivo y judicial puedan frenar al poder legislativo: cualquier incumplimiento de la ley por los funcionarios o jueces constituiría un delito de prevaricación o concusión que, además de la responsabilidad criminal, significaría su destitución. Por contra, el legislativo sí puede frenar a los otros dos poderes, gracias a su superioridad y es de ahí precisamente de donde deriva la teoría de los "límites" del poder; pero obviamente no puede emplearse en tales casos la palabra freno, sino todo lo contrario: se trataría de invasiones del legislativo sobre ambos, que da lugar en unos casos a los "gobiernos de asamblea", y en otros al "référé legislatif", a la interpretación auténtica de la ley por el propio órgano que la promulga (231).

En cuanto a los mutuos frenos entre el ejecutivo y el judicial pueden existir o no, según las distintas distribuciones de competencias que se efectuen y, normalmente, no tienen siquiera rango constitucional, sino incluso legislativo. Instituciones como lo contencioso-administrativo prueban que no solamente tales frenos podían no existir, sino que el poder ejecutivo, usurpando funciones judiciales, llegaba a auto-enjuiciarse (232).

De modo que la separación de poderes no limita el poder del Estado en absoluto. Las constituciones especializadas, un modelo de separación de 
poderes, no son limitadas, ni siquiera en el sentido de Hamilton, y no hay tampoco balances ni contrapesos ni de poderes ni de clases, porque es, a la vez, un modelo de concentración del poder en una sola clase. Los únicos límites son los que se derivan del propio concepto abstracto y genérico de ley, que no puede referirse a cosas o personas concretas y que no puede ser ejecutada por el propio órgano que la ha redactado. Las limitaciones, balances y contrapesos aparecen sólo en las constituciones mixtas, herederas del sistema de gobierno mixto, y se trata de limitaciones, balances y contrapesos dentro del poder legislativo y no entre los poderes legislativo, ejecutivo y judicial. Derivan de la intervención separada de las clases sociales dentro del legislativo y son contrapesos, balances y limitaciones fundamentalmente político-sociales, resultando las puramente jurídicas, una articulación de ese equilibrio social y sólo en tanto que se mantenga. La discusión al respecto se mueve, pues, en un ámbito extra-jurídico, alusivo a la libertad política, a las clases y a las "potencias", ajeno a cualquier afectación de los derechos y libertades ciudadanas.

Es inconcebible dentro del Estado un núcleo de fuerza autónomo que sea capaz de colisionar con otros y neutralizarse recíprocamente. Desaparecería en tales circunstancias. Para evitarlo concentra la fuerza en unos mismos resortes. Es obvio, si se pretende obtener la máxima eficacia de los instrumentos coactivos, que quedarían dispersos y podrían entrar en conflicto unos con otros si dependieran de entes distintos y separados: "Dividir el poder de un Estado -decía Hobbes- no es otra cosa que disolverlo, porque los poderes divididos se destruyen mutuamente uno a otro" (233). Cuando dos instituciones del Estado disponen de fuerza y capacidad de coacción, decía también Locke, o bien están en relación de subordinación o bien dependen de un órgano superior común a ambos. Se refería Locke a las relaciones entre los poderes ejecutivo y federativo: como ambos exigen disponer de la fuerza, es decir, como se trata de poderes reales y efectivos, no conviene separarlos en órganos distintos: "Tampoco sería posible -añadía Locke- confiar el poder ejecutivo y el poder federativo a personas que pudiesen actuar por separado porque, en ese caso, la fuerza pública se hallaría colocada bajo mandos diferentes, lo cual acarrearía, más pronto o más tarde, desórdenes y desgracias" (234). También para Rousseau, un ejecutivo repartido entre varios individuos siembra la desarmonía y ocasiona tiranteces entre ellos "incompatibles con el buen orden. Cada depositario de una parte de esta potencia se coloca, en virtud de esa parte, por encima de los magistrados y de las leyes en todos los aspectos" (235). La división de poderes no significa quiebra ninguna del poder efectivo del Estado: la fuerza coactiva del Estado, el poder real, siempre debe estar disponible en unos únicos centros decisorios. Los poderes legislativo y judicial se ven impelidos a acudir a dichos centros, de los que dependen en última instancia para llevar a efecto sus resoluciones.

El ejemplo del poder judicial es bastante ilustrativo de este monopolio de la fuerza del poder ejecutivo, porque en aquella época el poder judicial juzgaba pero no ejecutaba lo juzgado: quien ejecutaba lo juzgado era el poder ejecutivo. Duport expresó claramente esta idea en su informe:

Cuando los juicios se celebran legalmente, es necesario ejecutarlos; como son una aplicación de la voluntad general, es necesario que sean apoyados con 
toda la fuerza pública, porque sin eso la voluntad particular predominaría sobre la de todos. Es necesario, pues, situar junto a los jueces una fuerza capaz de vencer todas las resistencias. Es tanto más importante ordenar convenientemente esta fuerza, por cuanto que no se puede recurrir en el nuevo orden de cosas a los medios de acción que existían en el antiguo... Aquí, por el contrario, cada institución tiene su objetivo y su movimiento particular; aunque ordenado por el conjunto, ninguno debe salir de su esfera so pretexto de socorrer al otro... Esta fuerza que reside junto a los jueces no debe ser dirigida, sino sólo provocada por ellos... Debe conducir a un centro del que reciba el movimiento y la dirección. El hombre que se encargue de esta función necesariamente debe ser nombrado por el poder ejecutivo, instituído por él y a él subordinado: esto es necesario a la unidad de acción y a los principios de la monarquía, que quieren que, en último análisis, con reglas establecidas, toda fuerza de ejecución viene del jefe del poder ejecutivo y allí reconduce (236).

El art.1 del proyecto de ley de Duport así lo sentenciaba contundentemente: "Siendo el rey jefe del poder ejecutivo supremo, ningún juicio podrá ser ejecutado más que en su nombre y por oficiales que tengan en él su autoridad".

La posición de Barnave era la misma que la de Duport: "La decisión de un juez -dice Barnave- no es más que un juicio particular, como las leyes son un juicio general; uno y otro son obra de la opinión y del pensamiento, y no una acción o una ejecución. ¿Cuál es pues la posición del poder ejecutivo en relación con el poder judicial? Es la misma que en relación al poder legislativo. El rey está junto al tribunal para hacer ejecutar el juicio, como está al lado del poder legislativo para hacer ejecutar la ley". Para Barnave el rey es el jefe de la Administración, lo que le coloca en una cierta relación de superioridad, "no en la elección de los jueces -precisa- ni en los juicios, sino en la manera en que las leyes se ejecutan" (237). Si las decisiones judiciales son un reflejo de las leyes, la ejecución de unas y otras debe ser la misma: la función ejecutiva comprendía tanto la ejecución de la ley como la de la sentencia.

Esas mismas ideas son las que recoge la Constitución española de 1812. No contempla la función de ejecutar lo juzgado entre las atribuciones de los órganos judiciales; lo que el art.245 dice literalmente es lo siguiente: "Los tribunales no podrán ejercer otras funciones que las de juzgar y hacer que se ejecute lo juzgado". Es decir, le compete ordenar la ejecución, que deben llevar a cabo terceros al margen del poder judicial. No es un puro giro expresivo sin mayor trascendencia; el Discurso Preliminar se manifiesta en los mismos términos al decir que la autoridad de los jueces "es preciso que se extienda a hacer que se lleven a efecto sus decisiones para que no sean ilusorias, sin que por eso pueda influir de ningún modo en la suspensión o retardo de su ejecución" (238). Exactamente el mismo giro emplea el art.II del Decreto de 17 de enero de 1812: "La ejecución de las declaraciones de los tribunales de justicia, y lo económico de uno y otro ramo, será de cargo de las oficinas y empleados de la Hacienda Pública como las demás rentas, llevándose cuentas separadas de ambas".

En consecuencia, ejecutar lo juzgado era entonces una función ejecutiva y no judicial. 


\subsection{El rey como poder ejecutivo}

Se encuentran pocas definiciones de lo que es la ejecución o administración (239), quizá porque aunque doctrinalmente sea algo discutido, no cabe duda de que históricamente la ejecución tiene un carácter residual -y por tanto no homogéneo- en sus atribuciones, como apuntaron los juristas alemanes siguiendo a Laband. En España ha escrito Garrido Falla: "Así como los poderes legislativo y judicial se forman con las competencias que se han ido arrancando de manos del antiguo monarca absoluto, en cambio, el poder ejecutivo es justamente lo que queda en manos de aquel monarca una vez realizadas las antedichas sustracciones" (240). Esto significaba que el nuevo poder ejecutivo heredaba la configuración adquirida bajo el Antiguo Régimen, que su naturaleza no se alteraba con el cambio político. Al principio el constitucionalismo sólo pretendió limitar las facultades del rey y controlar su actuación, no cambiar su carácter: "El ejecutivo -escribe Jürgen Habermasconserva también en el estado de derecho burgués aquel carácter feudal del que la sociedad tenía necesidad... En el sistema de separación de poderes había hallado originariamente un equilibrio el conflicto entre la burguesía en vías de emancipación política y la monarquía. Al poder ejecutivo se incorporó el aparato administrativo del soberano que hasta entonces había sido absoluto" (241).

La teoría residual permite explicar por qué en los sistemas constitucionales mixtos, al ejecutivo se le habilita con una clausula general para suplir cualquier imprevisto. Precisamente por su arcaísmo, permite también comprender cómo en los estados de excepción pueda hablarse de una "devolución" (242) de competencias al rey, superponiéndose la consideración histórica a la dogmática jurídica.

A esta teoría residual responde el concepto de prerrogativa de Locke (243), poco divulgado por la influencia mercantilista que deja entrever(244) y, desde luego, muy poco concordante con el principio de "laissez faire", que se identifica normalmente con los orígenes ideológicos del liberalismo(245). De la noción de prerrogativa se hicieron eco, sin embargo, autores tan lejanos como Flórez Estrada (246) o Carl Schmitt (247) y fue una polémica trascendental del constitucionalismo inglés en los momentos inmediatamente anteriores a la revolución(248).

Locke se refirió a dos tipos distintos de competencias en la corona: una estrictamente ejecutiva, consistente en el mero cumplimiento de los mandatos legales, y otra, que calificó de prerrogativa, en la que incluía todo aquello que no pudiendo ser previsto por los legisladores, queda a su discreción; y afirma: "A esa facultad de actuar en favor del bien público siguiendo los dictados de la discreción, sin esperar los mandatos de la ley, e incluso en contra de ellos, se le llama prerrogativa" (249). Este segundo grupo de competencias del monarca era exponente de su naturaleza mixta, como órgano legislativo y ejecutivo a la vez, así como del carácter de "soberanía compartida" de la Constitución inglesa.

En la exposición de Locke, la prerrogativa estaba dominada por su excepcionalidad: "La prerrogativa -afirmaba- no es otra cosa que un poder 
puesto en manos del príncipe con objeto de que provea al bien público en aquellas situaciones derivadas de circunstancias imprevistas e indeterminadas y que, por esa misma razón, es imposible reglamentar con seguridad mediante leyes fijas e inmutables" (250). La discrecionalidad es el otro aspecto capital de la prerrogativa: la propia ley deja, en ocasiones, un amplio margen de maniobra al ejecutivo para su actuación y, en otras ocasiones, el cumplimiento literal y riguroso de la misma resulta contraproducente, por lo que se contemplan medidas tales como los indultos (251). Se trataba, pues, de un arcaísmo difícilmente justificable desde los nuevos principios jurídico-constitucionales que se trataban de crear, una reminiscencia del "Estado policía" (252).

Todas las claves radicaban en torno a la existencia o no de ley previa, en la capacidad de previsión del legislativo. De ahí que las competencias del rey no se circunscribieran a la pura ejecución de la ley, sino que contuvieran una habilitación general y residual para actuar en ausencia de ley. Tres principios coadyuvaban a dirigir esta actividad no habilitada por ley previa:

- la concepción del poder ejecutivo como delegado o fiduciario, cuya acción debe ir dirigida a determinados fines de interés general y no otros, y no en interés propio, sino de terceros (253)

- la responsabilidad (política y/o penal) de los ministros que permitía un control "ex post" de las acciones emprendidas, entablando entre ambos órganos -rey y Cortes- una relación de confianza (254) a través de los ministros, que debían refrendar los decretos del rey

- en la Constitución española de 1812 había también límites expresos a sus facultades en el art.172.

Lo trascendental de la ausencia de ley previa es la imposibilidad de intervención judicial: en tales casos la fiscalización judicial era imposible porque los jueces sí que no podían actuar en ausencia de ley y, en esas circunstancias ¿quién decidiría sobre la corrección de su actividad? Había dos posibilidades: la actividad ejecutiva de propia iniciativa sólo podía ser controlada, bien por la propia autoridad ejecutiva, bien por el legislativo, el cual, a su vez, podía pasar luego el tanto de culpa a los tribunales, pero ya en la vía penal.

Con esta configuración, quedaba en el monarca todo lo que no había podido ser cercado por la nueva legalidad constitucional (255) perfilando un vasto margen de maniobra del rey y de lo que éste representaba, las clases recicladas del Antiguo Régimen. Locke indica también cuál ha sido la evolución histórica de ambos grupos de competencias: antes casi todo era prerrogativa, y con posterioridad el legislativo ha ido tomando la iniciativa a fin no sólo de que la la actividad regia se someta al principio de legalidad, se convierta en mera ejecución, sino además que se reduzca hasta casi desaparecer o permanecer en la pasividad más completa. La tendencia general era conseguir que el ejecutivo se limitara a la tarea de orden público, al empleo de la fuerza para hacer cumplir la ley.

Ahora bien, en la concepción de Locke, la cámara legislativa se reservaba "ex post" la convalidación de las acciones emprendidas espontáneamente por el ejecutivo: "La prerrogativa, por consiguiente, no puede ser otra cosa -decía- 
que una autorización otorgada por el pueblo a sus gobernantes para adoptar diferentes iniciativas en casos no previstos por la ley $y$, en ocasiones, para obrar directamente en contra de la letra de la ley, mirando por el bien del pueblo, y a reserva de la aprobación ulterior de este último" (256). Esto reequilibraba en el pensamiento de Locke el funcionamiento de ambas piezas: rey y parlamento.

Destaca finalmente en la concepción de Locke, el carácter no delegado, sino propio o privativo de las facultades regias, es decir, que son previas o anteriores al reparto de poderes (257), que derivan de la soberanía compartida por la corona y el parlamento, y no delegación o fideicomiso de esa soberanía. Esto puede interpretarse también como superior: los poderes son delegados por alguien o algo (la soberanía, el poder político) que está por encima de ellos; la prerrogativa es bastante más que un mero poder. Como expusieron tanto Locke como el mismo Montesquieu (258), el pueblo sólo delega aquellas facultades que resultan imprescindibles para llevar a cabo aquello que no puede efectuar por sí mismo.

En este depósito originario del poder soberano reposa, en última instancia, el derecho de resistencia, el derecho a derrocar aquellos regímenes que no respetan los derechos inalienables e imprescriptibles. Y por otra parte, el rey, titular del poder ejecutivo, amén de las atribuciones propias del reparto de competencias derivado de la constitución, dispondría de otras, anteriores, superiores e independientes de la legalidad constitucional (259). El rey no se supedita completamente a los dictados de la soberanía popular en las constituciones mixtas, sino que puede equipararse a ella y compartir su soberanía (260).

Implícitamente está presente también el carácter sagrado de la personalidad real(261), cuya autoridad no dimana de fuentes terrenales sino divinas, y que, a la vez, en Inglaterra, es el más elevado cargo eclesial(262). A este punto está estrechamente vinculada la irresponsabilidad del rey(263), principio también aportado al constitucionalismo desde del Derecho privado: irresponsabilidad significa incapacidad de obrar y es una doctrina incorporada desde la teoría del Fisco, considerado éste como menor de edad, sujeto, pues, a tutela (264). Estas complicadas construcciones jurídico-formales de Derecho privado (265) prueban el tortuoso camino seguido para justificar y legitimar con un velo jurídico un profundísimo conflicto político: había dos voluntades, dos clases sociales, cada una de ellas con sus propios intereses, que trataban de hacerlos valer por medio de alambicadas proposiciones, demostrativas de la concurrencia de sendas nociones distintas de legitimidad: una de derecho divino (o tradicional y hereditaria), otra de origen humano, manifestada ésta en el sufragio. Y el sufragio excluye la irresponsabilidad, la irrevocabilidad.

El rey no es un órgano sino una persona, una institución personalísima -si se quiere- que el constitucionalismo difícilmente puede racionalizar en términos jurídicos, de Derecho público. Primero por su carácter preconstitucional y sagrado(266); segundo, por su componente legislativo y, en consecuencia, su naturaleza independiente pero no fiduciaria; y tercero, porque en cuanto poder ejecutivo, es el "primer funcionario del Estado" (267) y, en consecuencia, ni es independiente ni tiene carácter representativo(268). Se trata, pues, de una 
figura constitucionalmente contradictoria, dimanante de la naturaleza pactista de la constitución.

La Constitución de 1791 se autocalificaba de representativa: los representantes -añadía- son la Asamblea y el rey. El rey, por tanto, era representativo pero irresponsable. Todo giraba, en última instancia, en torno a esa noción de responsabilidad, y si el rey no podía ser responsable, alguien debía serlo, por lo que se trajo aquí la vieja institución del refrendo ministerial, la esencia misma del régimen parlamentario, su clave de bóveda, como la ha llamado E.Gordon (269). El rey era poder en tanto que autoridad legislativa, ya que como ejecutivo carecía de voluntad propia; era un mero servidor de la ley. En tanto que órgano legislativo era también independiente y, por tanto, inviolable pues si fuera responsable carecería de independencia, garantizada, en última instancia, por el refrendo. Las dos partes, pues, debían actuar al unísono, tanto en la actividad legislativa (veto) como en la ejecutiva (refrendo), hasta que el peso político inclinó la balanza en favor de una de ellas, quedando el refrendo como una ficción jurídica sin base real.

Lo más significativo del refrendo ministerial eran, una vez más, las excepciones. El mando del ejército, ejemplo clásico de prerrogativa regia (270), es uno de ellos. Así el art.2 de la ley de 19 de julio de 1889, adicional a la constitutiva del ejército, en virtud del cual, cuando el Rey "tome personalmente el mando", las órdenes que dicte no necesitarían ir refrendadas por ningún ministro responsable. Pero sin avanzar tanto en el tiempo, es claro que la sanción de las leyes en la Constitución de 1812 no requiere refrendo ministerial sino solamente oir al Consejo de Estado (art.236), porque evidentemente ya se produce el "concurso de voluntades supremas" entre las dos piezas, el rey y el parlamento. Entonces el problema es el inverso: comprobar qué actos parlamentarios no necesitan sanción real. En la Constitución de Cádiz solo las leyes (art.131.1) estaban sujetas a sanción, pero no así:

- las demás facultades del art.131, que no parecen ser leyes sino decretos

- la responsabilización de los ministros, que también revestía la forma de decreto (arts. 131.25, 228 y 229)

- el poder constituyente, la facultad de reforma constitucional que, aunque se rija por los trámites parlamentarios de las leyes (art.379), se la calificaba de "ley constitucional" (art.383) que, una vez aprobada por las Cortes recibía el nombre de "decreto" debiéndose presentar "al Rey para que le haga publicar y circular a todas las autoridades y pueblos de la Monarquía" (art.384).

La Constitución francesa de 1791 era mucho más precisa. A las resoluciones parlamentarias las llamaba "decretos" que, podían requerir sanción o no; en el primer caso se convierten en leyes si no son vetadas; en el segundo, se trata de meros "decretos". Pero, además, entre estos últimos distingue los "actos ejecutados como leyes" (responsabilización de los ministros, por ejemplo), de los "decretos que llevan el nombre de leyes", que son los relativos a los impuestos (271). 
Por lo tanto, mientras todos los actos del rey, en tanto que poder ejecutivo, debían ir refrendados, no requerían sanción real los actos ejecutivos y administrativos de la Asamblea o las Cortes.

\subsection{La reducción al mínimo de la actividad ejecutiva y su fragmentación}

En la batalla política en que se vió envuelto el principio de separación de poderes durante la revolución liberal, cristalizaron una serie de principios jurídicos cuyo objetivo no era otro que reducir a la mínima expresión a aquellos poderes -ejecutivo y judicial- que podían implicar un riesgo para las posiciones adquiridas por la burguesía, dividirlos internamente (el ejecutivo, entre los órganos centrales y los locales, el judicial entre órganos territorial y jerárquicamente estancados), y repartir aleatoriamente determinadas competencias entre ellos mismos, como en el caso de lo contenciosoadministrativo. Hubo, por ejemplo, funciones ejecutivas y administrativas -y también judiciales- que asumió el legislativo, lo que se ha calificado de "gobierno de asamblea", pero en este punto, los mayores esfuerzos se desplegaron para tratar de reducir al mínimo las competencias del rey y la Administración.

En el poder ejecutivo se introduce una doble fractura: orgánica con la creación de las municipalidades; y funcional también, separando las actividades puramente administrativas, de las que impliquen disposición de la fuerza pública. Ambos órganos (centrales y locales) y ambas funciones (administrativa en sentido estricto y orden público) están sometidas a un régimen jurídico totalmente distinto: los órganos locales y las funciones administrativas al Derecho privado; los centrales y el orden público al Derecho público. De manera que cuando aquellos primeros constituyentes hablaban de reducir al mínimo el poder ejecutivo, no se referían tanto al "gobierno de asamblea", a transferir la administración al legislativo o a las municipalidades, como a la reducción del ejecutivo a las puras tareas de orden público: había que eliminar el intervencionismo económico del Estado y, en los casos límite, no encomendar la gestión al ejecutivo central sino a las municipalidades primordialmente, porque de ese modo se sujetaban, como todas las actividades económicas (fuesen privadas o públicas) al Derecho privado (272). La Constitución de Cádiz, por mucho que hable de fomento y del despliegue de facultades del art.131, es fundamentalmente no intervencionista. A este respecto, primordialmente, hay que dejar constancia de que el fomento no es competencia del rey, sino de las Cortes (art.131.21) y, sobre todo, de los ayuntamientos (art.321.9) y diputaciones (art.325), mientras que el gobierno "político" de las provincias recae en el único cargo nombrado por el rey, el gobernador civil o "jefe político" en expresión de la época (art.324). No obstante, la Instrucción de 23 de junio de 1813 impuso un sistema bien distinto, mucho mas centralista y beneficioso para el gobernador civil, que será mucho más que un mero jefe "político". Pero en cualquier caso, hay que dejar constancia de que no es el rey quien dispone de ese tipo de competencias.

El concepto de fomento que emplean los doceañistas es una rémora del pasado, un concepto ilustrado (273). Más bien prevalece, como parece lógico imaginar, el abstencionismo económico. El papel de los ayuntamientos, dice el Discurso Preliminar, consiste en "fomentar por todos los medios posibles la 
prosperidad nacional, sin que los reglamentos se mezclen en dar a la agricultura y a la industria el movimiento y dirección que solo toca al interés de los particulares. Los vecinos de los pueblos -continúan los constituyentes- son las únicas personas que conocen los medios de promover sus propios intereses; y nadie mejor que ellos es capaz de adoptar medidas oportunas siempre que sea necesario el esfuerzo reunido de algunos o muchos individuos. El discernimiento de circunstancias locales, de oportunidad, de perjuicio $o$ de conveniencia solo puede hallarse en los que están inmediatamente interesados en evitar errores o equivocaciones, y jamás se ha introducido doctrina más fatal a la properidad pública que la que reclama el estímulo de la ley o la mano del Gobierno en las sencillas transacciones de particular a particular, en la inversión de los propios para beneficio común de los que los cuidan, producen y poseen, y en la aplicación de su trabajo y de su industria, objetos de utilidad puramente local, y relativa a determinados fines" (274). También el art.V.I de la Instrucción antes citada, alude a las providencias económicas de los ayuntamientos, que deberán ser "conformes a las leyes de franquicia y libertad"; y el art.XV del mismo capítulo, por su parte, prescribía que "en la ejecución de lo que sobre fomento de la agricultura, la industria y el comercio previene la Constitución, cuidará muy particularmente el Ayuntamiento de promover estos importantes objetos, removiendo todos los obstáculos y trabas que se opongan a su mejora y progreso". Fomento era, pues, eliminar las trabas y obstáculos a la libre iniciativa privada.

La creación de los nuevos ayuntamientos era algo decisivo en la revolución liberal (275). Era la palanca fundamental para romper el centralismo monárquico, y partir en dos grandes fragmentos la Administración pública (276), dejando al rey únicamente con la parte superior y quedándose la burguesía con las organizaciones locales (277), sujetos sus cargos a sufragio lo mismo que los escaños parlamentarios. De su trascendencia da idea el hecho de que la facultad de declarar la ley marcial fuera puesta en Francia por la ley de 21 de octubre de 1789 en manos precisamente de los ayuntamientos (278). Tanto la Constitución francesa de 1791 como la española de 1812 tratan el régimen local separadamente de lo relativo a la corona y al poder ejecutivo: no eran parte de la Administración, no ejecutaban las leyes, no eran poder o, quizá mejor, tenían su propio poder, si bien en el mismo plano que la sociedad y los particulares (279).

Hay, sin embargo, diferencias sustanciales entre el régimen revolucionario francés de 1791 y el sistema doceañista español, en lo que al régimen administrativo local se refiere, pues allí los ayuntamientos son órganos autónomos, separados del rey y el poder ejecutivo central. El régimen municipal de la revolución francesa supondrá dotar a los ayuntamientos de un elenco de competencias, tanto propias como delegadas por el gobierno y, finalmente, de una potestad auto-normativa desconocida en España (280). Significó un fraccionamiento del poder ejecutivo: los municipios eran independientes del rey y de la Administración central. Los cargos municipales eran electivos, siendo incompatibles con los de designación real, lo que convertía a los ediles en independientes por partida doble de la influencia centralista que dimanaba del jefe del ejecutivo. 
Por el contrario, en España (281) los ayuntamientos son meros instrumentos delegados del gobierno (282). Los cargos municipales dependen de la Administración central y carecen de competencias propias.

Pero hasta ahora sólo nos hemos preocupado por las relaciones de los poderes y los órganos del Estado entre sí, pero no con la sociedad, no en su funcionamiento. No todos los poderes, en general, se relacionan de la misma manera con el ámbito de lo privado; e incluso cada poder, en función de la clase de actividad que desempeñe, está sujeto a un régimen distinto. Lo que diferencia a la función ejecutiva de la judicial es que la Administración puede entrar en conflicto con los particulares, mientras que los tribunales no: por el contrario, dirimen las controversias entre particulares y, por tanto, también con la Administración cuando actua como un particular. La vinculación de los poderes, en cuanto integrantes del Estado, con las clases sociales y, al tiempo, la separación entre la sociedad y el Estado, pone de relieve el complejo haz de interrelaciones que el constitucionalismo pretende diseñar. Es significativo constatar cómo los primeros constituyentes recurren habitualmente al término "nación" y muy poco al de Estado (283), que la diferenciación entre Estado y gobierno no comienza a desarrollarse hasta Rousseau, y que no hay ninguna homogeneidad entre los diversos poderes.

En efecto, el legislativo se concibe como órgano más bien de la sociedad, aparece como una reunión de ciudadanos privados que dirige la acción pública pero no forma parte de ella. Mientras, el poder judicial dispone de supremacía y de "imperium" pero no de capacidad coactiva; su posición al respecto parece ambigua, de modo que Hegel estudiaba al poder judicial en el apartado dedicado a la sociedad civil, fuera pues del Estado (284). Lo que caracteriza a lo público es, en cuanto a su posición, la superioridad, el "imperium", y en cuanto a la forma de su actuación, el empleo de la coacción, la fuerza y la violencia. Ambas cualidades se reconocen con la mayor nitidez en el ejecutivo, que aparece como el aparato público por excelencia (285). Esos órganos ejecutivos así divididos son de muy distinta naturaleza y su funcionamiento se regula por normas de naturaleza también distinta. Sus órganos centrales, en general, heredan las cualidades del "Estado policía", del ámbito público como un área caracterizada por la prerrogativa, por el privilegio, por la fuerza y la violencia. Por el contrario, los ayuntamientos, encargados del "fomento", son instituciones que funcionan por el Derecho privado (286), en condiciones de igualdad con los particulares: "Al no ser policía, todas estas actividades de fomento -observa Villar Palasí- no son, no pueden ser ejercidas por procedimientos coactivos, no disfrutan de los privilegios del Poder; deben ser ejercidas por procedimientos de Derecho privado, en paridad de circunstancias con los particulares. Los procedimientos de Derecho público son solamente aplicables cuando se trata de actividades que miran a la conservación del orden público" (287).

Cabe pensar, en consecuencia, que si el fomento es una actividad de Derecho privado y si las municipalidades son más bien "asociaciones" privadas, agrupaciones de familias, que entes de Derecho público, los litigios a que diera lugar la actividad económica administrativa serían enjuiciados por los jueces ordinarios, que la Administración carecería de privilegio alguno en este punto. 
En el marco de la revolución, el interrogante surge en relación con el tipo de relaciones del ejecutivo y los ciudadanos; si esas relaciones sólo se conciben de forma abstencionista y pasiva, con carácter de orden público, o si, por el contrario, se admite el intervencionismo de la Administración y, en tal, caso en qué concepto. Se trata de conocer si esa intervención también disfruta de supremacía o si está concebida en términos de igualdad, de equiparción de la Administración a los demás particulares. En definitiva, si el "imperium" se generaliza a todo tipo de acción administrativa, engendrando una nueva forma de privilegio, o si hay áreas de actividad administrativa privatizadas. Es en este contexto donde hay que situar la polémica sobre lo contencioso-administrativo. $Y$ también aquí hay diferencias entre Francia y España.

En Francia se percibe desde el comienzo lo administrativo como algo que debe estar sujeto a un régimen especial, diferente de los particulares, superior a ellos. El preámbulo de la Constitución de 1791 afirma que no hay más superioridad que la de los funcionarios públicos en el ejercicio de sus funciones. La ley de organización judicial de agosto de 1790 ya atribuía a los cuerpos municipales competencia para cuidar de la ejecución de las leyes y reglamentos de policía, "y conocerán -añade- del contencioso al que esta ejecución pueda dar lugar". Además, el número 2 del art.III del Título XI extiende las atribuciones de los cuerpos municipales a "la represión y castigo de los delitos contra la tranquilidad pública". La superioridad de la Administración respecto a los particulares estaba claramente definida y dimanaba precisamente de su equiparación a los órganos judiciales. La fórmula quedó expresada en el art.22 de la Declaración de Derechos propuesta por Robespierre: "Todo ciudadano debe acatar a los magistrados y a los agentes del gobierno, cuando son los órganos o los ejecutores de la ley”.

En España la fórmula se ciñe únicamente a los jueces y magistrados, no a los funcionarios públicos. La superioridad de la Administración respecto a los particulares no aparece en la Constitución de 1812; de los arts.288 y 289 se desprende que la única superioridad es la de los jueces y magistrados. El "judicialismo" de esta Constitución no es más que eso precisamente: la única superioridad o "auctoritas" reconocida es la de los jueces y magistrados en el ejercicio de sus funciones; la Administración se equipara a los ciudadanos privados, carece de atribuciones judiciales comparables a las de la francesa en el orden contencioso-administrativo y debe acudir al proceso antes de hacer uso de la fuerza contra los particulares. Lo contencioso-administrativo en España no aparece hasta 1813 (288).

Se verifica aquí una relación distinta entre lo público y lo privado (289), donde lo administrativo se equipara a lo privado y todo debe reducirse a lo privado, desamortizarse y desvincularse. Sólo se concibe el "Estado policía", la actividad de orden público, dotada de "imperium". No se considera ninguna forma de intervencionismo estatal, y menos se le concede ningún trato privilegiado.

Por el contrario, en Francia, el 31 de marzo de 1790, antes de la aprobación de la Constitución, la Asamblea había aprobado el plan de trabajo propuesto por Barrère para la reorganización del sistema judicial, cuyo punto noveno planteaba si "los mismos jueces conocerán de todas las materias o se dividirán 
los diferentes poderes de jurisdicción para las causas de comercio, de la Administración, de los impuestos y de la policía”. Se centraba, pues, en la cuestión de la especialización judicial. La discusión comenzó el día 27 pero se suspendió precisamente en lo relativo a la Administración, a propuesta de Chapelier, ya que aún no se había discutido sobre el régimen tributario, que debía anteceder. El Comité de Constitución remitió un proyecto que se discutió el 5 de julio cuyo título XIV establecía "tribunales de administración" (290), discusión aplazada también por el mismo motivo. La Asamblea no pensó por entonces atribuir lo contencioso-administrativo a la Administración, sino a tribunales especializados.

Tampoco la alusión del art.13 (del Capítulo II) de la Ley de agosto de 1790 de organización judicial es una referencia, ni aún indirecta, a lo contenciosoadministrativo, sino que se trataba de impedir la reproducción de las facultades políticas de los Parlamentos. Este artículo ha soslayado totalmente todo el Título XI, que es mucho más importante y trascendental. Nadie como Hauriou ha puesto de manifiesto la fuente del error: según el profesor de Toulouse, el art.13 contiene "dos prohibiciones muy diferentes que entrañan, una la separación de las funciones administrativas y judiciales, y la otra la separación de lo contencioso" (291). La primera parte de la afirmación es correcta; la otra está, literalmente, inventada: no hay nada en aquel art.13 que se asemeje a lo contencioso-administrativo, como se desprende de su misma lectura: "Les fonctions judiciares -decía el artículo en cuestión- son distinctes et demeureront toujours séparées des fonctions administratives. Les juges ne pourront, à peine de forfaiture, troubler, de quelque manière que ce soit, les opérations des corps administratifs, ni citer devant eux les administrateurs pour raison de leus fonctions". Por el contrario, como se ve, alude claramente a las operaciones de los cuerpos de la Administración, no a los litigios ni a los pleitos entre ella y los particulares. Lo contencioso-administrativo no tiene relación alguna con este art.13: se limita a separar lo que es juzgar de lo que es administrar; para nada alude a los pleitos que la función de administrar puede implicar; ni tampoco dice que los jueces se limiten a juzgar y la Administración a administrar; y desde luego, para nada se refiere a ninguna clase de litigios y, por tanto, tampoco a los de naturaleza contencioso-administrativa (292).

Ahora bien, hay que referirse al Título XI, cuyo art.1 dice que los cuerpos municipales cuidarán de la ejecución de las leyes y reglamentos de policía, y "conocerán -añade- de lo contencioso a que esta ejecución pueda dar lugar". Además, el número 2 del art.3 de este mismo Título extiende las atribuciones de los cuerpos municipales "a la represión y castigo de los delitos contra la tranquilidad pública". Se trata, pues, de algo bastante más fuerte que lo contencioso-administrativo: se trata, ni más ni menos, que de la atribución de competencias en materia penal a los cuerpos municipales. Pocos días después (6-7 de diciembre), se aprobó el decreto que verdaderamente desarrolla lo contencioso-administrativo, distribuyendo las competencias entre órganos judiciales (impuestos indirectos, aguas, bosques, pesca, etc.) o departamentos de distrito (impuestos directos, daños, etc.).

Lo contencioso-administrativo no es más que un índice para valorar la extensión del intervencionismo del Estado y su naturaleza jurídica (pública o privada). Por sí mismo es una cuestión que carece de relieve jurídico- 
constitucional, si tenemos en cuenta la ausencia de especialización de los poderes. Ni tampoco se puede centrar en lo contencioso-administrativo única y exclusivamente el estudio de las relaciones entre la Administración y los tribunales (293), sino en otras materias también que, incluso, son aún más esclarecedoras. El verdadero problema del constitucionalismo no radica en que la Administración asuma facultades judiciales, principio absolutamente compatible con la separación de poderes, sino en que la Administración se juzga a sí misma, en que dispone de un estatuto jurídico especial, distinto y privilegiado frente a los particulares.

Por el contrario, quienes, siguiendo a Duguit, han sostenido la especialización de los poderes, para hacerla compatible con lo contencioso-administrativo, han sostenido que en aquella época se entendía que juzgar a la Administración era administrar y no juzgar (294). En mi opinión, los primeros constituyentes franceses, lo mismo que nosotros, entendían que juzgar a la Administración era juzgar (295). La atribución de competencias a los cuerpos municipales se verifica precisamente en una Ley de Organización Judicial, por lo que juzgar a la Administración era juzgar y no administrar.

El problema radica en quién juzga y quién administra, en qué materias y, finalmente, cómo juzga y cómo administra. Lo verdaderamente importante es que tales atribuciones jurisdiccionales se confieren precisamente a los cuerpos municipales y no a otros organismos cualquiera de la Administración, y que aparte de las competencias en materia penal, la competencia de los cuerpos municipales no es universal, sino que se ciñe a la aplicación de las leyes y reglamentos de policía precisamente (296). Los oficiales municipales estaban sometidos a la ley tanto como los jueces, por lo que resultaba indiferente quién decidiera el litigio; ambas autoridades -jueces y oficiales municipales- debían aplicar las mismas normas y estaban orgánicamente equiparados, tanto por su independencia respecto del rey, como por su acceso al cargo en virtud del sufragio, aspectos claves ambos en los que coincidían tanto las autoridades judiciales como las municipales.

No hay, pues, nada extraño ni excepcional en este sistema administrativo: la Administración juzgaba ciertamente, pero como ha quedado expuesto, la separación de poderes no implicaba especialización de funciones (297) y, además, bajo el concepto de Administración como titular de esa competencia hay algo radical y absolutamente diferente de lo que aparecería tras la etapa napoleónica.

Sin embargo, subsiste la pregunta: ¿por qué atribuyeron esas competencias precisamente a los cuerpos municipales y no a los jueces ordinarios? Los constituyentes franceses tenían esas dos opciones, y una tercera: la de crear tribunales especiales, tribunales administrativos. En realidad esta tercera opción, propuesta por Thouret, era la segunda, es decir, una vez descartada la opción de atribuir este tipo de competencias a los jueces ordinarios, pensaron no en la Administración, sino en tribunales especiales. Hubo, pues, un doble recorrido: extraer estas competencias de los jueces comunes y, además, concedérselas precisamente a la propia Administración y no a jueces especiales. El descarte de los tribunales especiales respondía a que estos se integraban en el poder judicial y no en la Administración: no era una solución 
sustancialmente distinta de la "judicialista" porque su especialización era funcional, no orgánica, porque se trataba de los mismos órganos judiciales ceñidos al conocimiento y aplicación de una parcela del ordenamiento jurídico. La alternativa de atribuir a la Administración competencias judiciales era compatible con la separación de poderes y, además, en la práctica, una solución más perfecta que la judicialista de Bergasse, Sieyes o Chabroud y, con seguridad, a la de Thouret, por su carácter excepcional tan repudiado en la época, de crear tribunales con competencia específica.

Una tal configuración de la Administración significaba y presuponía varias cosas al mismo tiempo:

- una política socio-económica intervencionista y no meramente pasiva

- que tal intervencionismo podía resultar conflictivo para los particulares, que la actividad administrativa no siempre resultaría benefactora sino también perjudicial

- una clara concepción de lo público como radicalmente distinto de lo privado, dotado siempre de "imperium" y, en fin, de un estatuto jurídico especial.

En definitiva, los constituyentes franceses se separaron del modelo inglés y en aquella distinción romanista entre lo público y lo privado, incluyeron a la Administración entre lo público, dotándola de "imperium" en cualquier tipo de actividad que emprendiera.

El modelo francés deriva, indudablemente, de razones políticas (298) e históricas más que jurídicas, y se relaciona con la forma y obstáculos que se levantaron ante la revolución francesa: mientras Inglaterra alcanzó un compromiso duradero entre las fuerzas sociales, Francia hubo de recurrir al terror para afianzar la revolución. Todo esto demandaba un estatuto especial de la Administración que le hacía inequiparable a los particulares y, desde luego, descartaba el "judicialismo", la sumisión total de la Administración a un régimen de legalidad, y mucho menos en las mismas condiciones que los particulares (299). El problema se planteó con mucha mayor agudeza que en tiempos de Locke: la Administración no sólo se limitaría a ejecutar la ley, sino que debía adoptar iniciativas en ausencia de ley.

En España la situación es bastante distinta. Ninguna de aquellas tres circunstancias aparece ni en la Constitución de Cádiz ni en el pensamiento de los doceañistas españoles, más próximos en este punto al modelo "judicialista" inglés (300): no se plantea ninguna forma de intervencionismo estatal, ni mucho menos éste se prevee conflictivo para los particulares $y$, en consecuencia, la única actividad administrativa privilegiada es la de orden público. Un aspecto importante a analizar, en este punto, es la evolución del patrimonio "del Estado", así como sus formas de contratación (301). Es usual en la legislación doceañista el empleo de la expresión "bienes nacionales" y fondos "del común del pueblo" (art.321.5 de la Constitución) para referirse a una primera forma de propiedad pública. Pero en realidad, tanto la nación como "el común del pueblo", eran expresiones alusivas a una colectividad de personas individuales y singulares; parece tratarse, en consecuencia, de una propiedad tan privada como la individual, administrada en un caso por el 
gobierno y en el otro por el ayuntamiento. La Instrucción de junio de 1813 hace varias menciones a hospitales, casas de expósitos y de beneficencia "de fundación particular de alguna persona" (art.VII del Capítulo I), así como pósitos (art.IX), y el art.IX del Capítulo siguiente regula expresamente determinados "establecimientos públicos de fundación particular", lo que parece una contradicción en los términos. En cuanto al Reglamento de la Tesorería de 7 de agosto de 1813, también regula las "rentas que se dirigen o administran por establecimientos particulares" (arts.II y VII del Capítulo I). En síntesis, y como decía un comentarista, aún en el trienio, "cualquier denominación, cualquiera título con que se alimente al fisco, se mantiene el monstruo de los gobiernos feudales y arbitrarios... Libertad constitucional y leyes fiscales son incompatibles" (302).

El "judicialismo" doceañista expresa precisamente que la única supremacía es la del poder judicial, y que la Administración sólo puede hacer uso de la fuerza contra los particulares si media previamente una decisión jurisdiccional habilitante. De aquí se ha deducido la tesis de que en España, a diferencia de Francia, no existió ninguna forma de desconfianza hacia los jueces, por la ausencia aquí de instituciones semejantes a los Parlamentos (303). La inexistencia aquí de lo contencioso-administrativo parece abonar tamaña conclusión: la confianza en los anteriores jueces fue lo que permitió que se les concedieran competencias también en esta materia. En realidad, ese recelo hacia los jueces (304) se vio aquí redoblado por:

- la continuidad de un sistema judicial sin ningún parecido con el francés, estrechamente sujeto al poder ejecutivo - la continuidad de los mismos jueces del Antiguo Régimen en sus puestos, sin jurado y sin electividad de los cargos judiciales.

No deja de sorprender el riesgo que corrían los doceañistas al atribuir a los viejos magistrados del Antiguo Régimen el control de las decisiones del ejecutivo, que contrasta con el art.VII del Decreto de abolición de los señoríos, que al tiempo que suprime los derechos exclusivos (caza, pesca, hornos, etc.) que quedan al libre uso de los pueblos "con arreglo al derecho común y a las reglas municipales establecidas en cada caso", determina la competencia de las Cancillerías y Audiencias en unos casos (art.IX) y en otros no, no admitiendo ninguna demanda al respecto "llevándose inmediatamente a efecto lo mandado, según el literal tenor de este decreto", y ordenando a los tribunales que se abstengan "de resolver e interpretar".

La Constitución de Cádiz procedió a una distribución funcional estricta de competencias, por la que atribuía al ejecutivo lo gubernativo, económico y político, y a los órganos judiciales lo contencioso o litigioso entre partes. En Cádiz esa separación tan estricta no proviene tanto de la influencia inglesa, que es indiscutible, como quizá de una falta de madurez y experiencia política en la dirección de un Estado que los nuevos gobernantes no había conquistado, sino que se había caído a sus pies, lo que les condujo a planteamiento irreales e impracticables (305).

El concepto de fomento de que se hace uso en la propia Constitución, parece ser un reflejo de ello, al que ya me he referido. Tampoco parece que los primeros constituyentes españoles atisbaran la posibilidad de relaciones 
conflictivas y litigiosas entre la Administración y los ciudadanos. Lo contencioso-administrativo no existe para los doceañistas porque -en su criterio- la Administración juega un papel contemplativo, tutelar del orden público y de la libre concurrencia individual, no intervencionista: "El verdadero fomento -afirma el Discurso Preliminar- consiste en proteger la libertad individual" (306). Por otro lado, su actividad primordial consistiría en la ejecución, actividad que no podía dar lugar a conflictos, tanto por secundar un mandato legislativo, como por el carácter abstracto o genérico de la misma, que en nada debía afectar a los intereses ciudadanos, concepción que tuvo su reflejo en el art.1.Il del Reglamento del Consejo de Estado de 1812: "Son asuntos gubernativos aquellos de los que resulta regla general de buen gobierno". En el debate sobre la creación de este órgano consultivo, reclamaba Espiga su competencia en aquellos asuntos que produzcan "regla general" (307). Idénticamente, el Discurso Preliminar pretende que el gobierno se "conduzca por máximas y no por ideas de uno de los Secretarios del Despacho que, además de ser interesadas, necesariamente han de ser movibles" (308).

Cuando la Administración ejercitaba sus facultades, debía hacerlo en beneficio del interés general, del bien común, por lo que axiomáticamente, nadie debía salir perjudicado: "El objeto del Gobierno -dice el art.13 de la Constitución- es la felicidad de la Nación, puesto que el fin de toda sociedad política no es otro que el bienestar de los individuos que la componen". Esto parece algo asumido plenamente por nuestros constituyentes.

En la Instrucción de 23 de junio de 1813 comienza ya a desarrollarse lo contencioso-administrativo como una parcela de la función jurisdiccional atribuída a la propia Administración y, más definidamente, a los jefes políticos y a las Diputaciones. Los primeros conocían de los recursos contra las providencias económicas y gubernativas de los Ayuntamientos y alcaldes (art.18.I), así como de las elecciones municipales (art.3.II). Pero aquí acaba cualquier semejanza imaginable con la ley francesa de 1790 de organización judicial, por las siguientes razones, que sucintamente apuntamos:

- se trataba de una norma administrativa, y no judicial como la francesa

- las competencias no se atribuían a los municipios, sino a organismos supramunicipales de nivel provincial

- los cargos de esos organismos no eran electivos (a excepción de las Diputaciones que lo eran parcialmente) sino de designación gubernativa

- los organismos no eran tampoco autónomos ni descentralizados, sino dependientes del jefe político e instituídos precisamente para controlar a los ayuntamientos

- es reseñable, por fin, la paradoja de que en España los alcaldes fuesen a la vez jueces (art.275 de la Constitución) pero sólo en materia civil y penal, en tanto que no se les concedía competencia en la mencionada Instrucción para conocer de lo contencioso-administrativo.

Pocos meses antes de esta Instrucción, el art.32.Il del Reglamento de Administración de Justicia de 1812 había preservado los juzgados de 
Hacienda, los consulados y los tribunales de minería, siquiera con carácter provisional. Parecía que, formalmente, también aquí se caminaba hacia la atribución de competencias a la Administración en materia contenciosoadministrativa. Pero la disposición del Reglamento de 1812 era provisional y se demostraría poco después. En efecto, en materia tributaria, el Decreto de 13 de setiembre de 1813, en contradicción con la Instrucción de dos meses antes y con el Reglamento judicial, otorga competencia a los jueces comunes en este campo. Ahora bien, aparece en esta norma otra institución típicamente administrativa que contribuía a edificar un estatuto singular del ejecutivo, no ya sólo en comparación con los particulares, sino a costa de los particulares, el principio "solve et repete": "En las causas sobre cobranzas de débitos de contribución -decía el art.12- no se admitirá apelación de la sentencia condenatoria sino después de hecho el pago" (309).

Parece claro que ya en 1813, es decir, sólo un año después de aprobada la Constitución de Cádiz, lo contencioso-administrativo aparece en España, por lo que parecen alejadas las tesis de Santamaría Pastor, que situa su origen en el trienio liberal (310), la de Blanca Lozano, que lo retrasa más allá de 1830 (311), y la más común, que la hace coincidir con los orígenes de década moderada (312).

\section{El sistema judicial constitucional}

El liberalismo organizará todo el sistema judicial de forma que despejara el riesgo de encontrar la presencia de un tercer poder en discordia, de manera que el poder judicial era "en cierta forma" nulo, como dirá Montesquieu. Era nulo precisamente porque:

- desde el punto de vista de su función, carecía de voluntad propia, no era representativo, sino brazo ejecutor de la ley - desde el punto de vista de su organización, no era un cuerpo permanente, sino temporal, basado en el jurado y en la elección de los jueces - desde el punto de vista de sus competencias, carecerá de atribuciones en materia política, ya que se limitaba conocer sobre materias de Derecho privado.

Cada una de estas tres perspectivas merece un examen separado a fin de comprender de manera cabal el papel de los jueces dentro del constitucionalismo liberal.

\subsection{La funcionalidad constitucional de los jueces}

La función de los jueces bajo el liberalismo estará definida por la supremacía del Parlamento y de la ley dentro de la separación de poderes. No es, pues, algo sustancialmente distinto de la misma supeditación a la que se vio sometido el poder ejecutivo, para quien las leyes eran mandatos emanados de un órgano constitucionalmente superior. El liberalismo también impuso una estricta subordinación de los jueces a la ley, que tuvo una doble proyección: si hay ley previa, por la férrea sumisión a su texto; y si no la hay, porque el tribunal no puede suplirla invocando la costumbre o la jurisprudencia: el órgano judicial carece de iniciativa, ya que el vacío legal es una área de libertad del individuo. 
La función de la ley consistía en habilitar la intromisión en la sociedad civil; la incidencia pública sobre los derechos individuales o la propiedad debía hacerse por medio de la ley y de su correspondiente aplicación judicial. La ley no era una limitación ni una sujeción del Estado, propiamente hablando, sino más bien del ciudadano; era la forma de limitar su propiedad y su libertad.

Los límites de la libertad -escribirá Sieyes- se ubican allí donde el ejercicio de aquella comienza a dañar la libertad de otro, siendo únicamente competencia de la Ley reconocer tales límites y señalarlos.

Fuera de estos límites establecidos por la Ley, todo es libre para todos, pues la unión social no tiene por objeto solamente la libertad de uno o varios individuos, sino la libertad de todos (313).

No es, en definitiva, nada distinto de aquel dicho popular de que la libertad de cada cual acaba donde empieza la de los demás: el límite entre ambas es lo que ley dibuja y, por ello, la ley deben redactarla "todos", la nación, por medio de su expresión constitucional: el Parlamento. Los jueces eran quienes debían hacer operativa esa ley sobre el ciudadano. $Y$ "todo lo que no está prohibido por la ley es del dominio de la libertad civil y pertenece a todo el mundo" (314). La libertad política, decía el Discurso Preliminar de 1811, se podía suspender o restringir, "pero la libertad civil es incompatible con ninguna restricción que no sea dirigida a determinada persona, en virtud de un juicio intentado y terminado según la ley promulgada con anterioridad" (315). Por sí mismos, sin previa ley, los jueces no podían invadir la libertad civil: en ello se empeñaron, fundamentalmente, los primeros constituyentes, así como por apartar a los jueces del conocimiento de litigios que no fueran estrictamente privados y particulares entre ciudadanos.

El poder judicial era, por tanto, verdadero poder público, dotado de "imperium" para poder obligar a los ciudadanos; es más: era el poder público por antonomasia precisamente porque actuaba compulsivamente sobre los particulares. De ahí la liquidación de las "jurisdicciones" señoriales, en las que no existia poder judicial, sino justicia, privada, donde el juez era al tiempo parte interesada.

No obstante, el juez, además de su subordinación a la ley, tenía en Francia una segunda fuente de autoridad: su carácter electivo. Se trataba de un poder delegado, puesto por encima de la sociedad pero, al mismo tiempo, elegido por la propia sociedad.

El poder judicial era poder público sólo y en virtud de que su competencia no se extendía mas allá de lo doméstico. Se trataba, sin embargo, de un poder estrictamente subordinado y, pese a su naturaleza electiva en Francia, no tenía carácter representativo, porque los representantes eran la Asamblea y el rey, mientras que el poder judicial era puramente ejecutivo, sin voluntad propia y, por ello, sin capacidad de iniciativa. Su función era de mera exégesis de la ley; aplicar la ley al caso concreto, cumplir con la voluntad de la ley, no con la del juez. Esto significa que la función judicial se reduce a un puro raciocinio, a una labor intelectual privada de todo carácter decisorio: las sentencias judiciales son razonamientos y no actos volitivos. En el constitucionalismo primitivo iniciativa y publicidad son siempre contradictorios. 
Para el liberalismo, la función de juzgar es una prolongación de la actividad legislativa, y consiste en poner de manifiesto el contenido de la ley en un caso controvertido, en pronunciar las palabras de la ley, según expresión conocida de Montesquieu. Juzgar no solo no consiste en interpretar las leyes, sino que los jueces tienen expresamente prohibido interpretarlas si hay texto expreso de la ley. Según Montesquieu, las sentencias "deben corresponder siempre al texto expreso de la ley. Si fueran una opinión particular del juez, se viviría en la sociedad sin saber con exactitud los compromisos contraídos con ella" (316). Del mismo modo, en su informe a la Asamblea constituyente diría Bergasse: "El poder judicial estaría, pues, mal organizado si el juez dispone del peligroso privilegio de interpretar la ley o de añadir algo a sus disposiciones" (317). Lo mismo repetiría luego Duport, para quien el "impropiamente llamado" poder judicial "está obligado a consultar a los hombres designados por la Constitución antes de hacer ejecutar las leyes civiles cuando su aplicación parezca dudosa" (318). La posibilidad de interpretar las leyes les parecía a los constituyentes franceses, muy similar a la facultad de amonestación ("remontrance") de los viejos Parlamentos (319), quienes antes de promulgar ("enregistrement") las leyes podían hacer observaciones, censuras y críticas para justificar su negativa a registrarlas, sin lo cual no entraban en vigor; es decir, disponían de una especie de veto que los constituyentes quisieron desterrar impidiendo a toda costa la generalización de interpretaciones que no dimanasen de la Asamblea, desarrollando para ello el "référé legislatif", que tanto podía ser voluntario para el tribunal como incluso obligatorio (320). La ley de organización judicial de 24 de agosto de 1790 obligaba a los jueces a "transcribir pura $y$ simplemente en un registro particular" las leyes (art.XI, Título II), prohibiéndoles tomar parte en el ejercicio del poder legislativo e impedir o suspender la ejecución de las leyes (art.X) y recomendándoles dirigirse a la Asamblea cada vez que lo crean necesario para interpretar las leyes (art.XII).

Es importante precisar, en contra de una idea muy difundida (321), que nunca se prohibió a los tribunales interpretar las leyes, que el "référé legislatif" no prohibía la interpretación de las leyes, sino que por el contrario la presuponía: había lugar a establecer una interpretación auténtica cuando las interpretaciones de los tribunales eran divergentes (322). Tampoco confundieron, como afirmó Calamandrei (323), la interpretación abstracta o auténtica con la concreta o judicial, sino que existían dos órganos encargados de interpretar las leyes, la Asamblea y los tribunales, y dos tipos de interpretaciones distintas, la auténtica y la judicial. Por ello, el art.28 de la Constitución belga de 1830 establecía: "La interpretación de las leyes por vía de autoridad pertenece solamente al poder legislativo". Por vía de autoridad significa una interpretación con valor superior a la de los tribunales. Cuando las normas prohiben a los tribunales interpretar las leyes, se están refiriendo siempre a la interpretación reglamentaria y aluden continuamente a las leyes expresas o al texto preciso y concreto de una ley, que no cabe alterar por vía interpretativa. Por ello, si bien la casación sólo se autorizó por infracción de ley, la interpretación errónea fue considerada como tal y admitida la casación por dicho motivo. El término "ley expresa" se repite hasta la saciedad en los clásicos y en la legislación de la época.

En España, al debatir la comisión constitucional acerca del Tribunal Supremo, "el señor Romanillos propuso si convendría a este Tribunal la facultad de 
decidir las dudas que ocurriesen a las Audiencias sobre la existencia o no existencia de leyes positivas para algún negocio y de consultar cuando no pueda decidir por sí. Agradó en general el pensamiento y quedó para tomarse en consideración en la sesión próxima" (324). El laconismo de las actas de la Comisión no ofrece más información, pero los arts.131.1 y 261.10 de la Constitución de Cádiz fijaban indubitadamente como facultad de las Cortes tanto la creación como la interpretación de las leyes.

El alcance de la interpretación auténtica queda en España bastante claro a la vista del Decreto de 24 de marzo de 1813 que establece la responsabilidad de los magistrados por fallar contra ley expresa, pero declarando al mismo tiempo: "Cuidarán los tribunales de no incomodar a los jueces inferiores con multas, apercibimientos, ni otras condenas por errores de opinión en casos dudosos, ni por leves y excusables descuidos". Por tanto, no cabía interpretación con ley expresa, pero sí cuando ésta fuese de dudoso o discutible contenido.

En cualquier caso, parece claro que la facultad de juzgar quedaba reducida a un mecanismo totalmente automático que muy poco margen dejaba al juez. La jurisprudencia era propia del Antiguo Régimen y no tenía resquicio alguno bajo el constitucionalismo: "El resultado de esta concepción y de disposiciones semejantes -afirmó Hauriou- fue exaltar la ley y abatir al juez" (325). De la producción legislativa se esperaba casi todo: una normativa universal, sin lagunas y de unívoca comprensión. Las circunstancias imprevistas daban lugar al estado de excepción, a la prerrogativa, algo que estaba fuera de las expectativas del constitucionalismo (326). En los asuntos civiles, no cabía la analogía, de modo que ante la existencia de lagunas no cabía dictar sentencia, hasta que el Código napoleónico (art.4) impuso el principio de que los jueces no podían dejar de resolver sobre los litigios planteados. El Código napoleónico trató de cortar los abusos de los tribunales, que habían recurrido frecuentemente al "référé legislatif" para eludir pronunciarse, siendo reiterado el criterio del Tribunal de Casación en el sentido de que tales inhibiciones constituían un abuso de poder de los tribunales (327).

La idea clave de todo el constitucionalismo es la misma que ya expusiera Montesquieu: el poder judicial "juzga las diferencias entre particulares" (328). Los tribunales eran el poder ejecutivo de las cosas que dependen del Derecho Civil: sólo entenderían en cuestiones derivadas del Derecho privado, es decir, en los litigios entre particulares. De aquí se deduce que los jueces no son garantes de los derechos de los ciudadanos frente al Estado, pues la verdadera garantía, en este aspecto, radica en la existencia (o inexistencia) de ley. En Montesquieu -como luego pensarían los doceañistas- no es que lo público, lo político, lo gubernativo quedaran fuera del alcance de los jueces, sino que esas cuestiones no podían ser fuente litigiosa. Si excepcionalmente se producían litigios, si hubiera que juzgar un delito político, por ejemplo, Montesquieu postulaba la competencia jurisdiccional del Senado, un órgano colegislador(329), principio del que es reflejo el Tribunal de Cortes del art.128 de la Constitución española de 1812.

En lo demás, la Administración se sometía al Derecho común en cuanto al régimen jurídico de su actividad que, tanto para Montesquieu como para la Constitución de Cádiz (art.170), tenía dos vertientes: la acción diplomática o 
internacional que, por volcarse en el exterior, no incumbía a los propios ciudadanos; y la de orden público interior que, por ser esencialmente pasiva y preventiva, lejos de incidir en la vida civil, aseguraba su libre desenvolvimiento. Si de la prevención hubiera de pasarse a la represión, la competencia se trasladaba a los tribunales (330).

\subsection{La organización del sistema judicial}

Para poder comprender el sistema judicial liberal no basta describir su forma específica de organización: hay que partir de si verdaderamente trataron de organizar a los jueces o si, por el contrario, pretendieron difuminarlos y desburocratizarlos. En efecto, de las fuentes originarias se desprende que la idea originaria fue la de diluir a los jueces dentro de la misma sociedad; en términos contemporáneos, puede decirse que los jueces no serían un "aparato del Estado", sino más bien de la sociedad (331). Difícilmente podría hablarse de un poder que careciera de un cuerpo funcionarial estrictamente ramificado y jerarquizado. En palabras de Montesquieu:

El poder judicial no debe darse a un Senado permanente, sino que lo deben ejercer personas del pueblo, nombradas en ciertas épocas del año de la manera prescrita por la ley, para formar un tribunal que sólo dure el tiempo que la necesidad lo requiera.

De esta manera, el poder judicial, tan terrible para los hombres, se hace invisible y nulo, al no estar ligado a determinado estado o profesión...

Los otros dos poderes podrían darse a magistrados o a cuerpos permanentes, porque no se ejercen sobre ningún particular, y son, el uno la voluntad general del Estado y el otro, la ejecución de dicha voluntad general (332).

El desempeño de funciones judicial, según Rousseau, no podía configurarse más que de forma pasajera (333). Estas ideas se repitieron durante la revolución francesa: "El poder judicial -dirá Bergasse al comienzo de los debates en la Asamblea- estará mal organizado si los tribunales se componen de un gran número de magistrados y forman así poderosas compañías" (334). La versión de Duport ante la Asamblea presenta un acabado impecable de esta elaboración constitucional: el pueblo soberano sólo delega en sus representantes aquellas funciones que no puede ejercer por sí mismo; pero las funciones judiciales sí las puede asumir sin necesidad de intermediarios, a través del jurado (335). Un poder de ejecución requería una burocracia sólida y ramificada (abogados, fiscales, secretarios, etc.) que es precisamente lo que los constituyentes franceses pretendieron evitar a fin de no reproducir los Parlamentos bajo nuevas denominaciones. Incluso Duport reniega de los términos "magistrados" y "tribunales" para preferir el empleo de "jueces" y "cortes": los tribunales eran sinónimo de Antiguo Régimen, cuerpos sedentarios, germen de corporativismo o, lo que es lo mismo, de privilegios (336). Según Duport, la magistratura es una función política, mientras que la judicatura es una función meramente civil, esto es, relativa a las relaciones de los individuos entre sí (337). Los constituyentes franceses organizaron el sistema judicial sobre principios comisariales, temporales y electivos, mientras que otros países, como Estados Unidos o España, optaron por los cargos judiciales vitalicios, oficiales y sedentarios. De este modo, mientras en Francia 
los jueces, pese a estar dotados de "imperium" no salían del ámbito de la sociedad destinataria de sus resoluciones, en Estados Unidos y España se optaba por la burocracia y la profesionalidad.

La descripción organizativa del sistema judicial liberal debe comprenderse desde la dicotomía establecida por Bodino entre oficial y comisario, entre la temporalidad y la perpetuidad de los cargos públicos, cuestión que el autor, lejos de resolver con una fórmula abstracta, trató en dependencia con varios factores, entre ellos, la forma de Estado concreta que tuviera cada país (338). Puede hablarse así de dos técnicas diferentes de organización judicial en el constitucionalismo: una técnica oficial y otra comisarial; la primera característica de Estados Unidos y España, la otra propia más bien de Francia. Naturalmente, no existieron dos modelos puros y radicalmente diferenciados porque, como aconsejó Montesquieu, "en toda magistratrura hay que compensar la magnitud del poder con la brevedad de su duración" (339).

\subsubsection{La experiencia judicial inglesa}

La idea de Montesquieu de anular políticamente al poder judicial estaba condicionado por el ejemplo de la revolución inglesa, donde se había alcanzado una fuerte preponderancia o asimilación del parlamento sobre el aparato judicial(340). Se había verificado allí tras la guerra civil, un delicado equilibrio político entre el rey y el parlamento (341) que es la clave de toda la etapa de la Restauración (1660-1685). Luego Jacobo II, entre otros desafíos que lanzó para romper ese equilibrio, revitalizó algunos tribunales excepcionales (la Cámara Estrellada, el Tribunal del Norte) que habían sido abolidos (342) e incluso promovió el nombramiento de determinados cargos judiciales, entre ellos el de Jeffreys como "Lord Chancellor", a través del cual dispuso el acaparamiento de los oficios judiciales por los adictos al absolutismo.

Si se examina el "bill of rights" se observará que buena parte de los reproches a los Estuardo se refieren al sistema judicial: dispensa de las leyes, procesamiento de prelados, creación del tribunal de delegados, fianzas excesivas para obtener la libertad provisional, y especialmente dos que llaman la atención:

- la acusación ante el Tribunal Real por delitos de los que era competente el Parlamento

- la integración en los jurados de personas parciales, corrompidas y no cualificadas y, singularmente, reprueba que personas que no eran propietarios hayan intervenido como jurados en delitos de alta traición.

Consecuentemente, el "bill of rights" reclama la ilegalidad de las comisiones constituídas en tribunales por disposición de la Corona y, además, que el jurado se constituya regularmente, y más en concreto, "que los jurados que decidan la suerte de las personas en procesos de alta traición, deberán ser propietarios libres"; la crítica, por tanto, se dirigía contra el desplazamiento de la burguesía del ejercicio de funciones jurisdiccionales. 
Como en Europa continental, Inglaterra bajo el Antiguo Régimen experimenta un fraccionamiento de su sistema judicial: el absolutismo, como método de centralización, impulsa la creación de comisiones extraordinarias, que se superponen (343) a los tradicionales órganos judiciales locales, herencia de la dispersión territorial del primer feudalismo y servidores de la nobleza terrateniente. Lo realmente peculiar de la situación inglesa (344) es que ambos aparatos judiciales se enfrentan entre sí durante la revolución, y mientras las comisiones extraordinarias se alinean con el absolutismo, la magistratura local sigue a su clase y, en íntima conexión con la burguesía urbana, se opone a Jacobo II y sale reforzada de la revolución (345). Todo el posterior entramado judicial se organizará en torno a este aparato judicial local (346). El sistema judicial había tratado de de ser instrumentalizado por los Estuardo para romper el equilibrio entre las dos potencias. El procedimiento que se utilizó fue la centralización jurisdiccional, las comisiones extraordinarias, que chocaron con los jueces locales, fieles servidores de la nobleza terrateniente, a su vez estrechamente aliada y entrelazada con la burguesía (347). La organización judicial tenía, pues, un peso político susceptible de alterar el equilibrio entre la revolución y la contrarrevolución. Esto fue lo que trataron de impedir Montesquieu y los primeros constituyentes franceses.

Justamente en medio está el sistema judicial norteamericano, cuyos "padres fundadores" expusieron las mismas quejas frente a la metrópoli que se habían manifestado allí un siglo y medio antes. Los colonialistas, dice la Declaración del I Congreso Continental de 1774, han extendido "la jurisdicción de los tribunales del Almirantazgo, no solamente para el cobro de dichos tributos, sino también para la vista de aquellas causas que se originan en el interior de un condado". Se lamentaban de la injerencia en las competencias de los jueces, pero también de la manipulación en la composición de los órganos judiciales: "Los jueces que antes eran electivos han pasado a depender únicamente de la Corona por lo que respecta a sus salarios... Los colonos pueden ser trasladados a Inglaterra para juzgarles allí, acusados de traición, sedición o encubrimiento de la traición cometidos en las colonias; y en virtud de una ley posterior, se han realizado procesamientos en casos incluidos en dicha disposición". Los reproches eran los mismos que antes habían lanzado los revolucionarios ingleses contra la realeza.

\subsubsection{El debate de la asamblea constituyente francesa}

En Francia fue precisamente la organización jurisdiccional lo que suscitó más largas y arduas discusiones, tanto entre los primeros constituyentes como entre los redactores de la Constitución jacobina de 1793, debates que pareces superfluos cuando versan sobre el poder al que se califica de "nulo". Los revolucionarios ganaron la votación por un estrecho margen: sólo 503 votos contra 450. "La Asamblea, en menos de un mes, había resuelto todas las grandes cuestiones constitucionales -escribió Duvergier de Hauranne- $y$, en menos de quince días, todas las grandes cuestiones administrativas, sin que ni unas ni otras hubiesen dado lugar a grandes debates. Sucedió de otra manera en las cuestiones judiciales que, durante varios meses retuvieron la atención de la Asamblea" (348). 
Hubo, sin embargo, un primer intento de conciliación entre la burguesía y la aristocracia que no llegó a cuajar. Thiers explicó el fracaso del compromiso en relación con el bicameralismo frustrado, aduciendo que la transacción no era posible antes del choque, de la prueba de fuerzas, de la revolución: pretender el compromiso antes del combate -decía- significaba firmar la paz antes de empezar la guerra (349). También expuso Soboul que la solución de compromiso fracasó tanto por la oposición del campesinado como por la de la nobleza, que en Francia, al contrario que en Inglaterra, estaba íntimamente ligada a los privilegios y era impermeable a los nuevos principios burgueses: la huída del rey a Varennes demostró "la oposición irreconciliable de la monarquía del Antiguo Régimen y la burguesía liberal" (350). En el ámbito judicial el compromiso político tuvo su reflejo en el art.IV.I de las leyes de agosto de 1789: "Todas las justicias señoriales se suprimen sin indemnización; y sin embargo los oficiales de esas justicias continuarán en sus funciones hasta que la Asamblea nacional provea el establecimiento de un nuevo orden judicial".

Pero ese nuevo orden judicial no podía ser más radicalmente antitético del preexistente. Las facultades legislativas de los Parlamentos no solamente se sobreponían a la ley y contrariaban el principio de soberanía nacional, sino su misma unidad, su aplicación uniforme (351). En su seno estaban precisamente enquistados la nobleza terrateniente y el clero: "Desde hacía mucho tiempo escribía Tocqueville- los nobles franceses ya no intervenían en la administración pública más que en un sólo punto: la justicia. Los principales de ellos habían conservado el derecho a tener jueces que decidían ciertos procesos en su nombre e incluso de tarde en tarde promulgaban reglamentos de policía dentro de los límites del señorío; pero el poder real había ido cercenando, limitando y subordinando gradualmente la justicia señorial, hasta el punto de que los señores que todavía la ejercían la consideraban más como una renta que como un poder" (352). Si se pretendía luchar contra la aristocracia señorial había que liquidar los Parlamentos; y a la inversa, si se pretendían eliminar los Parlamentos, se encontrarían con la más férrea oposición de la nobleza y el clero, sin posibilidad alguna de composición intermedia. A diferencia de Inglaterra, la revolución francesa se opuso a todos los aparatos judiciales del Antiguo Régimen. En su informe a la Asamblea en agosto de 1789, Bergasse se lamentaba públicamente del fracaso del acuerdo con la nobleza y de verse obligado a presentar "un orden de cosas absolutamente diferente" del que está establecido desde hace tanto tiempo: "Si nos hubiera sido posible mejorar simplemente en lugar de destruir para reconstruir de nuevo, lo hubiéramos hecho, tanto más a gusto por cuanto la nación, sin duda, no ha olvidado todo lo que debe a sus magistrados... Las circunstancias presentes demandan otro orden judicial distinto del que hemos respetado tanto tiempo... Es pues indispensable que una revolución absoluta se opere en el sistema de nuestros tribunales... Una revolución en la administración de justicia se hace inevitable" (353).

Al retomar el debate en marzo del año siguiente, en nombre del comité constitucional, Thouret se expresa en términos muy parecidos: "Lo que el comité os ha propuesto entraña la destrucción necesaria de todos los tribunales existentes, para sustituirlos por una creación de nuevos establecimientos. Se presenta aquí la primera cuestión: ¿es necesario regenerar a fondo el orden judicial, o no se puede dejar subsistir en el nuevo edificio varias partes del 
antiguo?... Nada concuerda menos con los principios de la constitución que aquellos sobre los que está establecido el antiguo orden judicial". Más adelante Thouret desmenuza precisamente esos fundamentos clasistas del viejo orden judicial "integrado por clérigos y nobles" y que no constituían más que "corporaciones de antiguos privilegiados": el nuevo régimen liberal "no tiene enemigo más peligroso que el espíritu de cuerpo, y no hay cuerpo cuyo espíritu y osadía sean más de temer que esas corporaciones judiciales, que han erigido en principios todos los sistemas favorables a su dominación" (354).

Al salir en defensa de los Parlamentos, las facciones más conservadoras, capitaneadas por Cazalès, no hicieron más que impulsar el desmantelamiento total del aparato judicial absolutista. El mismo Cazalès planteó también la pregunta de si se iba a edificar un sistema judicial totalmente nuevo o solamente a reformar el antiguo. La propia derecha, con su defensa a ultranza del Antiguo Régimen, promovió una corriente de opinión favorable a la primera solución.

Es imposible resumir todas las cuestiones que fueron objeto del debate. Nos limitaremos al examen de las relaciones rey-tribunales, que dió lugar a dos posicionamientos radicalmente divergentes. Por una parte, Cazalès afirmaba, en frase célebre, que el rey debía nombrar a los magistrados lo mismo que a los oficiales de su ejército: aquellos le estaban tan subordinados como estos. La izquierda (Barnave), por contra, exigía que los fuesen elegidos por sufragio. No es que los revolucionarios no quisieran controlar al poder judicial: lo que sucedía es que lo querían controlar ellos, es decir, pretendían que quien controlase a los jueces fuese la Asamblea, no el rey (355).

Esta misma discusión revistió otra forma: si los jueces se nombrarían vitalicia o temporalmente; si los nombraba el rey debían ser cargos vitalicios; es el sistema adoptado por la Constitución de Cádiz en los arts.171-4, 252 y 253 (356). El método pareció a los contituyentes franceses tener demasiadas concomitancias con el Antiguo Régimen: los cargos perpetuos semejaban un privilegio y no eran muy diferentes del régimen patrimonial o privado, característico de la justicia señorial: "En nuestra Constitución, señores -decía Duport- sólo el monarca es perpetuo; todos los demás individuos encargados de funciones públicas entran al cabo del tiempo en el seno de la sociedad... Los hombres que saben que una vez jueces no bajarán de su tribunal, están tentados de mirar sus funciones como una alienación de la sociedad en su favor y a ellos como una clase distinta en el Estado" (357). La elección por sufragio de los jueces era el complemento imprescindible del jurado: "Si se abandona al gobieno en exclusiva la elección de los magistrados -llegó a escribir Tocqueville- los tribunales de justicia pronto no serán más que bandas de comisarios" (358).

La electividad de los jueces y el jurado eran al poder judicial lo que la milicia y el porte de armas eran al ejército profesional y permanente. Los ciudadanos debían ser juzgados por sus iguales: según Sieyes, "este método de administrar justicia es el único que pone al abrigo de los abusos del poder judicial" (359).

Aquí el contraste con la timidez de la Constitución de 1812 es también total, y aparece claramente reflejado en el Discurso Preliminar, donde los propios 
constituyentes relacionan las dos cuestiones, es decir, el jurado y el nombramiento de los jueces profesionales. El jurado les parece ideal, pero "por ahora" inviable. Los jurados, dice el Discurso, tienen la ventaja de que no hay que temer de ellos "la perpetuidad de sus destinos, el espíritu de Cuerpo de Tribunales colegiados, y en fin, el nombramiento del Gobierno, cuyo influjo no puede menos de alejar la desconfianza por la poderosa autoridad de que está revestido". Los diputados eran plenamente conscientes de lo que hacían, de que en este punto se apartaban radicalmente, no solamente de los constituyentes franceses de 1789-1791, sino del mismo Montesquieu; pero, como ellos mismos reconocen, "hacer una revolución total en el punto más difícil, más trascendental y arriesgado de una legislación, no es obra que pueda emprenderse entre los apuros y agitaciones de una convulsión política" (360). Pese a su "judicialismo" el constitucionalismo de Cádiz asume plenamente, como veremos, la subordinación del poder judicial al gobierno.

El nuevo sistema judicial diseñado por la Asamblea constituyente no llegó a imponerse cabalmente en la práctica, pese a haberse definido con tanta claridad y rotundidad. La organización judicial llegó a alcanzar cierto relieve sólo en las discusiones y en la tribuna de la Asamblea, sólo en un aspecto teórico-onstitucional.

La configuración futura de los tribunales en Francia siguió derroteros muy distintos de los originarios proyectos de la Asamblea constituyente. En los demas países europeos, en los que la revolución burguesa no alcanzó ni la intensidad ni las dimensiones de aquel país, los perfiles del sistema judicial nunca alcanzaron a configurarse sobre las premisas originarias de los constituyentes franceses. En la propia Francia, el modelo de la burguesía revolucionaria será sustituído por otro, fruto de las concepciones moderadas y doctrinarias, no muy alejadas de las que expusiera Cazalès ante la primera Asamblea constituyente. El art.47 de la Carta de 1830 decía: "Toda administración de justicia emana del Rey y se ejerce en su nombre por jueces que él mismo elige e instituye". El sistema doctrinario se caracterizará, no solamente por el mantenimiento de las funciones jurisdiccionales en el ámbito privado, sino además, por la constitución de órganos parajudiciales en lo contencioso-administrativo, la supeditación total al ejecutivo y la constitución de un cuerpo burocratico judicial permanente.

Burocratizada de esa forma, la organización judicial se adscribe orgánicamente al ejecutivo, transformándose en un pequeño apéndice suyo. La Constitución española de 1812 ya definía al rey como "jefe del gobierno" lo mismo que como "primer magistrado" de la nación (361). La judicatura es incapaz de desequilibrar el balance político por su propia irrelevancia; por su marginalidad política, no necesitaba ya de ninguna reforma, por lo que mantuvo en buena parte una configuración heredada del Antiguo Régimen, como deja constancia también el caso español, reflejado en el propio Discurso Preliminar de Cádiz (362). No obstante, se puso un órgano supremo a la cabeza que representaba la capacidad fiscalizadora de la naciente burguesía sobre los jueces: el Tribunal Supremo, cuyo "principal atributo", según el Discurso Preliminar, "debe ser el de la inspección suprema sobre todos los jueces y Tribunales encargados de la administración de justicia” (363). Por contra, en Francia esa misma función la llevaba a cabo el Tribunal de Casación por otros medios, por vía de recurso, 
para lo que ideó un instrumento procesal absolutamente original como la casación (364) que en España no nace hasta 1838 y sólo para supuestos muy concretos. De ahí que el Tribunal Supremo en España se constituya como órgano más bien político que jurisdiccional (365), ya que las Audiencias agotaban todas las instancias posibles (art.262). En las actas de la Comisión redactora de la Constitución aparece tachada y suprimida como facultad del Tribunal Supremo la de "conocer de todos los recursos que conforme a las leyes se interpongan de providencias de las Audiencias en la Península e Islas adyacentes" (366). Se eliminaba la posibilidad de una interpretación uniforme de las leyes y, por tanto, la existencia misma de la jurisprudencia. Cuando el Tribunal Supremo asumía funciones jurisdiccionales, se trataba sobre todo del enjuiciamiento de los ministros, destitución de consejeros de Estado y de jueces, residencia de funcionarios, etc. En lo demás "su conocimiento ha de limitarse a si se han observado o no las leyes que arreglan el proceso -afirma el Discurso Preliminar- debiendo abstenerse de intervenir en lo sustancial de la causa, que habrá de remitirse al Tribunal competente para que ejecute lo que haya lugar. El recurso de nulidad y el juicio de responsabilidad que, en su consecuencia, puede originarse en el Tribunal Supremo de Justicia, asegurarán el celo y justificación de los Tribunales superiores de provincia" (367). Se rechazó, pues, el sistema francés de Altos Tribunales que confiaba la responsabilidad a órganos de origen parlamentario, creando por vez primera un régimen de responsabilidad "judicial" pero de matriz gubernativa, de manera que, en última instancia, la responsabilidad sería examinada por magistrados nombrados por los mismos funcionarios enjuiciables, y de ahí su debilidad intrínseca frente al modelo francés revolucionario.

Al margen de la novedad del Tribunal Supremo, en países como España, ni siquiera se plantea la cuestión de la transformación radical del sistema judicial (368), de manera que los juzgados y tribunales apenas cambian de la configuración que traían del Antiguo Régimen. Cualquier cambio significaba un desembolso cuantioso, en un momento de agobio para el erario público que es característico de las primeras décadas del siglo XIX (369). La atribución de lo contencioso-administrativo a los tribunales supuso un duro golpe para la recaudación fiscal, impotente no tanto por ineptitud de los jueces para resolver con agililidad las reclamaciones, sino quizá principalmente porque ahora la aristocracia dejaba de estar exenta de tributación (370) y los jueces que debían ejecutar las contribuciones eran, en buena parte, sus antiguos servidores o cómplices en las mismas maquinaciones políticas. La solución mas fácil, barata y eficaz no era reformar el sistema judicial, sino transferir una parte de las competencias a la propia Administración. No puede perderse de vista la estrecha relación existente entre la nobleza señorial y los jueces locales: constituyendo un privilegio histórico fundamental su exención fiscal, era difícil que los jueces se aprestaran a ejecutar las deudas fiscales de quienes habían sido hasta ayer mismo sus jefes inmediatos. Es uno de los múltiples ejemplos que jalonarán la historia judicial española, demostrativo de la íntima vinculación entre los problemas judiciales y los hacendísticos (371).

Si incluso el texto constitucional gaditano reconocía la ausencia de reformas en el aparato judicial, peor quedaría en las constituciones y leyes subsiguientes, ninguna de las cuales alcanzó a rozar siquiera el techo -por bajo que fueraalcanzado en 1812. El desequilibrio posterior entre la Administración y los 
tribunales es, en realidad, un reequilibrio, un ajuste realista entre las fallidas pretensiones doceañistas y la continuidad perceptible en la práctica forense (372). En España no desaparecen los tribunales privilegiados y la centralización administrativa es muy débil (373). Las comisiones extraordinarias más importantes son las militares (374), que aquí tendrán siempre un caracter local por su dependencia del capitán o gobernador militar de cada circunscripción, y responden a la desconfianza de los liberales hacia unos jueces civiles estrechamente ligados a la vieja aristocracia.

La organización judicial, por tanto, además de tener cercenados sus contornos por órganos administrativos y parlamentarios con atribuciones jurisdiccionales, estaba dividida entre sí por fueros privilegiados supervivientes del Antiguo Régimen y políticamente neutralizada por la reducción de sus competencias al ámbito privado, así como por su dependencia burocrática del ejecutivo.

El lugar político de los jueces era entonces radicalmente divergente del actual. En ningún país tiene hoy la importancia que tuvieron en la revolución francesa el jurado y la electividad de los jueces, que los aproximaba -hasta confundirloscon la sociedad civil, y más en concreto con la propia burguesía como estamento social. Más que del Estado formaban parte Tercer Estado. Hoy, por contra, los jueces son cuerpos burocráticos, sedentarios y profesionales; forman parte integrante del aparato del Estado y están alejados de la sociedad. Su radio de competencias es mucho mayor que entonces y disponen de fórmulas -llamadas de "autogobierno"- antes impensables, por cuanto los pocos jueces en aquella época existentes dependían de los otros dos poderes. Entonces dichos jueces profesionales eran un riesgo para los derechos cívicos, y hoy se les califica de garantes de esos mismos derechos.

Ha cambiado, pues, tanto la relación de los jueces con la sociedad como con los otros poderes públicos. El Estado entonces no se concebía uniforme y homogéneamente sino que, como hemos visto, los tres poderes se relacionaban de forma distinta en la antítesis -básica y fundamental- entre el Estado y la sociedad, entre lo público y lo privado.

En cualquier caso, ese Estado configurado de tal forma, no está sujeto a la ley, sino a la constitución; y los jueces no estaban sujetos a la constitución, sino a la ley. La ley no limitaba la acción del Estado sino la de los ciudadanos. De entonces a hoy, por tanto, va un abismo jurídico insuperable que no se puede salvar con paralelismos que sólo contribuyen a extender la confusión.

La determinación de la funcionalidad de los jueces dentro del sistema político de separación de poderes, supone no solamente concretar la influencia de la política en las resoluciones judiciales (la manida cuestión de la "independencia" de los jueces), sino también la jurisdiccionabilidad de lo político; precisar, en suma, si los jueces disponen de competencias para resolver asuntos políticos $y$, si la respuesta es positiva, en qué forma se procede a ello, cuestiones todas ellas que si hoy tienen sentido, entonces carecían totalmente de él. No obstante, no será vano un esfuerzo discursivo, aunque sea puramente hipotético, para remarcar las profundas discordancias que ha introducido el paso del tiempo dentro de los mismo conceptos jurídicos. 


\subsection{La reducción de la competencia judicial al ambito privado}

El sistema judicial perfilado por la revolución francesa tenía su raíz de origen y su legitimidad en la misma sociedad o, por mejor decirlo, en el Tercer Estado precisamente. La burguesía, por medio del sufragio, elegía a los jueces, y por medio del jurado asumía por sí funciones jurisdiccionales. De ese modo pretendían reemplazar a los viejos magistrados absolutistas.

Pero este era sólo uno de los recorridos; por el otro, esos jueces y jurados tendrían limitadas sus competencias precisamente al ámbito privado, de manera que la libertad y la propiedad no pudieran verse afectadas más que por decisión judicial, por resolución de unos jueces y jurados dispuestos en la forma que acabamos de exponer.

Montesquieu diferenció entre la ejecución de las leyes politicas, que correspondía al rey, de la de las leyes civiles, que correspondia a los tribunales. En palabras de Tocqueville, es consustancia a los órganos judiciales ocuparse sólo de los intereses particulares y resolver los pequeños litigios (375); consideraba como una "máxima de Estado que todos los procesos en los cuales se mezcle un interés público, o que nazcan de la interpretación de un acto administrativo, no son de la incumbencia de los jueces ordinarios cuya única misión es sentenciar entre intereses particulares". Quedaban fuera del alcance de los tribunales las cuestiones generales, las disputas políticas, todo aquello que rebasa el ámbito de lo doméstico.

Esta ha sido una tradición muy arraigada a lo largo del liberalismo del siglo XIX. Montesquieu, diferenciaba cuidadosamente el ámbito de lo privado y de lo público, "las leyes que dan origen a la libertad política con relación a la constitución, de aquellas que lo hacen con relación al ciudadano" (376), distinción que está también en Beccaria (377), en Rousseau (378) y que también recordó Bergasse ante la Asamblea constituyente (379). En el orden penal se reproduce esa misma dicotomía: "Aunque todos los delitos son públicos -afirmaba Montesquieu- se distinguen, sin embargo, los delitos verdaderamente públicos de los delitos privados, llamados así porque ofenden más a un particular que a sociedad entera" (380).

La distinción entre leyes civiles y políticas es paralela a la que en el plano procesal se desenvuelve entre los "negocios comunes", por emplear la terminología de la Constitución de Cádiz, y los demás. Según el Discurso Preliminar "la naturaleza de ciertos negocios, el método particular que conviene al fomento de algunos ramos de industria, juntamente con los reglamentos $y$ ordenanzas que más que al derecho privado pertenece al derecho público de las naciones, pueden exigir Tribunales especiales y de un arreglo particular. Los Consulados, los asuntos de presas y otros incidentes de mar, las Juntas o Tribunales de minería en América, y tal vez el complicado y vicioso sistema de rentas, mientras no se reforme desde su raíz, podrán requerir una excepción de la regla general de Tribunales. La naturaleza variable de sus negocios es la que ha de decidir si deben subsistir o extinguirse; $y$ esto nunca puede ser objeto de la Constitución, sino de leyes particulares" (381). De ahí la aprobación del art.278, en el que se autoriza la creación de tribunales especiales "para conocer de determinados negocios", expresión que repite el 
Decreto sobre conflictos de abril de 1812, haciendo referencia, igualmente, a la existencia de "especies diversas de jurisdicción" (art.III). Con más claridad, el art.39 del Reglamento de las Audiencias de octubre de 1812 ceñía estrictamente la competencia de los jueces de primera instancia al castigo "de los delitos comunes", expresión reiterada luego por el nuevo Reglamento de 1835.

Resulta bastante claro, por tanto, que en aquella primera Constitución y en la legislación ordinaria subsiguiente, se permitieron tribunales especiales por razón de la materia, a diferencia de la de Bayona (art.98), donde esto quedó expresamente prohibido. Se desprende de aquí con bastante nitidez, según entendemos, la falta de homegeneidad litigiosa, la discriminación de la materia jurisdiccional por razón del fondo, de la que derivará la discriminación de los propios órganos judiciales competentes. Se había concluído, pues, en el extremo opuesto del de partida: la naturaleza del asunto se determina por la naturaleza del órgano competente. Se alcanza el autoenjuiciamiento: la Administración se revisa a sí misma y los parlamentarios son juzgados por los parlamentarios. Lo contencioso ya no es homogéneo, sino que depende de la naturaleza material de procedencia, en última instancia del órgano que de lugar a ella. Se ha impuesto el punto de vista orgánico, de manera que son competencia de la Administración todos los asuntos, aún los contenciosos, que tengan origen en ella. Se justificará "ex post", a partir de la monarquía de julio, y de forma artificial, que un asunto administrativo por el hecho de ser contencioso no deja de ser administrativo; de donde la conclusión es lógica: el órgano llamado a fallar debe ser también administrativo. La distinción entre lo público y lo privado se traslada al área jurisdiccional: ésta ya no es homogénea sino que a su vez se fracciona también entre lo contencioso público y lo privado.

En el fondo latía una vez mas la cuestión clave de los estamentos sociales y de las potencias reales actuantes en la sociedad. Si se refuerza el protagonismo del ejecutivo y la Administración no es ya para beneficiar a las viejas clases aristocráticas, sino que era la burguesía quien disponía de sus resortes, mientras seguía siendo dudosa la fidelidad política de los jueces. Confiándoles lo contencioso-administrativo se les daría un protagonismo, una fuerza política, una superioridad peligrosa (382). Lo decisivo no es ya si el asunto es litigioso $o$ no, sino si está adscrito a un órgano o a otro; si está adscrito a la Administración es administrativo, por más que revista la forma de pleito. De aquí se deduce la importancia que adquiere la distribución de competencias: cuantas más reciba la Administración, más litigios podrá resolver. Con el criterio orgánico de distribución de poderes, la Administración duplica todas sus atribuciones en detrimento de la jurisdicción: junto a la Administración "activa", surge una Administración "pasiva" que resuelve los pleitos en que se vea envuelta la primera. La razón es que los asuntos públicos eran vitales para la subsistencia de todo el sistema político y no podían quedar en manos de los tribunales ordinarios (383).

La organización judicial resultaba un poder minúsculo cuando su radio de acción no iba más allá de los litigios domésticos, privada del conocimiento de las cuestiones políticas, y también de las contencioso-administrativas a partir de 1813. Pero esa ha sido históricamente la tendencia del liberalismo a lo largo 
de todo el siglo pasado: reducir la competencia judicial al entorno privado. Esa ha sido también tradicionalmente la postura de los juristas liberales españoles del siglo XIX, imbuídos de moderantismo. Por ejemplo, Ortiz de Zúñiga escribía que el poder judicial "es el encargado en la aplicación de las leyes civiles o relativas a los intereses individuales y de la resolución de las controversias entre particulares y del castigo de los que violan las leyes penales... Ejerce la potestad de aplicar las leyes solamente en los juicios civiles y criminales, esto es, en las controversias sobre propiedades e intereses privados, $y$ en la averiguación y castigo de los delitos" (384). Por las mismas fechas afirmaba también Juan Miguel de los Ríos que el ejecutivo "resuelve sobre las relaciones de los ciudadanos con el Estado, sobre las dificultades que se deciden por la ley política; el judicial resuelve las relaciones de los ciudadanos entre sí, sobre los negocios cuya solución depende de las disposiciones del derecho civil, de los títulos, de los convenios y de la posesión de los litigantes. El poder judicial no decide sino sobre las contestaciones actualmente existentes; sobre los pleitos que nacen de un derecho que se litiga, o sobre un hecho que causa un perjuicio a un individuo determinado, y que no interesa a la sociedad sino secundariamente, y por su influencia sobre el orden público. El ejecutivo tiene mayor esfera de actividad; puede disponer para lo futuro y obrar sin ser excitado; es decir, que pueden dar decisiones que se le han pedido, y tomar medidas de conservación y de precaución sobre los objetos que por su naturaleza, su destino o la necesidad o costumbre de usar de ellos interesan a la totalidad de los ciudadanos" (385). A finales de siglo, para defender la "jurisdicción retenida" razonaba de la siguiente manera Mellado: "La autoridad judicial se funda en las relaciones de los ciudadanos entre sí; conoce de los asuntos que interesan al Estado como particular y ultima los negocios cuya solución depende del Derecho civil. La autoridad judicial sólo decide y ejecuta lo que nace de un derecho puesto en tela de juicio o de un hecho que perjudica a un individuo determinado y que sólo interesa a la sociedad secundariamente". Y más adelante añade: "La práctica y la jurisprudencia determinan asimismo que son asuntos de orden judicial aquellos que se refieren a intereses privados, y que son asuntos de la Administración todos aquellos que se refieren al interés público" (386).

Todo eso significaba que el poder judicial compartía una parte ínfima del poder, que su competencia estaba notablemente reducida en asuntos políticamente trascendentes, que su parte en el poder es verdaderamente minúscula en comparación con otros aparatos del Estado: militar, tributario, policial, etc. Pero en definitiva el poder judicial era un poder, o al menos lo comparte; en este punto pocas dudas podemos albergar.

\subsection{La supuesta mediación jurisdiccional entre los demás poderes del Estado}

Dada la supremacía del poder legislativo era entonces absurdo pensar -salvo en los Estados Unidos- en un control de constitucionalidad de las leyes, en que un poder subordinado, el judicial, controlase al superior, el legislativo y que, en lugar de someterse a la ley, la pusiera en cuestión.

Pero hay una cuestión distinta que importa examinar aquí a fin de continuar la crítica de la interpretación dada hoy a la frase de "que el poder frene al poder": 
¿es al menos el poder judicial una instancia mediadora entre los otros dos poderes, entre el ejecutivo y el legislativo? De ser cierta, esta función, que parece tan apropiada entre sus competencias, incrementaría sustancialmente su relevancia política. El problema radica en que el poder judicial era poder en tanto disponía de supremacía frente a los ciudadanos en sus litigios privados, pero si los litigantes eran poderes del Estado, ese "imperium" desaparecía, el poder judicial dejaba de ser poder. $Y$ además, tampoco los litigantes estarían en el mismo plano, no serían iguales por la supremacía del legislativo. Cabe pensar todavía si, pese a ello, los jueces podrían intervenir como simples mediadores o árbitros imparciales. Parece que tampoco porque los jueces están sujetos a la ley, a las normas emanadas de uno de los poderes, por lo que parece que no podrían resultar neutrales. No obstante, la mediación surge precisamente, como observó Schmitt, cuando no hay norma previa: la misma ausencia de ley sería aquí la garantía de la imparcialidad judicial. Pero entonces se trataría de una decisión política, no jurisdiccional, cuya validez dependerá de los poderes conferidos por los litigantes: "Aquí está el límite sostenía Schmitt- de toda forma judicial y de toda composición. El Estado no es sólo organización judicial; es también cosa distinta a un juez arbitral o un componedor neutral. Su esencia estriba en que adopta la decisión política" (387).

En el ámbito privado los litigantes pueden desprenderse de parte de sus atributos para llegar a una composición, pero en el ámbito público eso no es posible, porque las normas son de orden público, cogentes e imperativas. Y sobre todo, los poderes son, en última instancia, articulaciones jurídicas de clases o fuerzas sociales: no se trata del problema jurídico de que el poder su autolimite, ni de que "el poder frene al poder"; no es un problema técnico, sino político. No puede haber equilibrio jurídico si hay desequilibrio político, pero a la inversa, sí puede haber equilibrio político con desequilibrio jurídico. La cuestión, por tanto, se reduce a preguntar si los jueces podían ser habilitados por las clases sociales para mediar entre ellas, si eran la instancia idónea para llevar a cabo esa mediación. Nuevamente todos los argumentos conducen a una respuesta negativa.

En Montesquieu los tres poderes se reducen a dos potencias representativas de otras tantas clases sociales. En este punto cabe subrayar una de las distorsiones más llamativas cometidas por Duguit para forzar su interpretación del principio de separación de poderes, al afirmar que los tres poderes tienen carácter representativo (388). Si esto fuera cierto, la pregunta es obligada: ¿a quién representan los jueces?, o quizá mejor: ¿a qué clase social representan los jueces? Habría de traerse aquí todo el debate sobre la "desconfianza" del liberalismo contra los jueces, desconfianza que hay que entender sólo en términos de clase: no es una desconfianza hacia "los jueces", sino precisamente hacia los jueces absolutistas y hacia el sistema judicial absolutista. Para los liberales, los jueces profesionales eran representativos de una clase social, la aristocracia feudal, enemiga de la revolución; esta es precisamente la situación que debía terminar.

En el constitucionalismo liberal los jueces no debían representar a nadie (389), lo cual se debe interpretar en el sentido de que carecen de voluntad propia, de voluntad política diferente a la de los otros dos poderes. En términos de clases 
sociales, si el ejecutivo es una función encomendada a la clase social derrotada por la revolución y el parlamento a la burguesía victoriosa, ¿a qué clase social representan los jueces? Montesquieu, siguiendo también aquí a Locke, se proponía dejar a los jueces ceñidos a asuntos domésticos, fuera de todo contacto político desde el punto de vista competencial; desde el orgánico, el "autogobierno" ni se planteaba, por lo que quedaban adscritos al legislativo o al ejecutivo. En resumen, pues, el equilibrio político se daba dentro del poder legislativo y la única mediación posible era de tipo social o político, no jurídica ni técnica.

Pero no se trataba solamente de que los jueces no tuvieran carácter representativo, sino que hay que añadir esta circunstancia al hecho de que tampoco tenían voluntad propia, sino que se trataba de meros "portavoces" del legislativo. Es decir, ni disponían de autodeterminación ni tampoco ejecutaban, estrictamente hablando, las decisiones de otros, sino que "resolvían" para que el ejecutivo lo pusiera en práctica: lo primero les diferenciaba del legislativo, lo segundo del ejecutivo.

Los jueces debían permanecer al margen de las luchas políticas entre la burguesía y la aristocracia, no podían mediar en ese conflicto sin tomar partido. "Cuando se atribuyen funciones políticas a los jueces -decía Duport- se les hace demasiado fácil sustraerse a toda responsabilidad legal, aliando sus intereses con los intereses de quienes ejercen las demás funciones políticas y que serían llamados a juzgarles" (390). Los jueces estarían, como apuntaba Schmitt, por encima del parlamento, de la voluntad general: constituirían una instancia suprademocrática "y la voluntad política no se determinaría a través de la libre competencia por el poder entre partidos políticos dotados de 'chances' fundamentalmente iguales para alcanzarlo" (391). Para evitar tales situaciones, los jueces debían ser un poder nominal, sin fuerza política real, tan extremadamente neutral que ni siquiera podían ejercer funciones arbitrales.

El planteamiento de esta cuestión se relaciona con el de la atribución a los jueces de funciones garantizadoras de los derechos y libertades, de mediación entre los ciudadanos y el Estado, según el planteamiento que ya elaborara Hegel (392), y que presupone implícitamente una actividad gubernativa infractora y un remedio judicial frente a ella. Sin embargo esto es una construcción teórico-jurídica reciente, no extrapolable a los orígenes del constitucionalismo, por diversas razones:

- los derechos, como ya hemos repetido, se localizaban en la constitución o fuera de ella en "declaraciones" preliminares (Francia) o en "enmiendas" posteriores (Estados Unidos), pero nunca en leyes y, por lo tanto, fuera del alcance competencial de los jueces, sujetos única y exclusivamente a la ley

- no solamente los jueces no eran garantes de los derechos, sino que eran un riesgo para esos mismos derechos: había que proteger a los ciudadanos no con los jueces, sino de los jueces

- las libertades públicas o políticas no eran derechos subjetivos (393): su naturaleza los dejaba fuera de lo jurídico y dentro de lo político; su defensa era de tipo político-social, se ejercía por medio de la Asamblea y estaba incardinada al "derecho" de resistencia en última instancia. 
La función garantista de los jueces no iba más allá de la propiedad privada.

La situación en Inglaterra, especialmente durante el reinado de Carlos II, fue muy paradigmática al respecto: "El equilibrio de los poderes real $y$ parlamentario en Inglaterra -expone Trevelyan- anulaba constantemente la efecacia del gobierno, como en la cuestión del ejército permanente. Había que decidir de ua vez por todas cuál de los dos poderes debía prevalecer" (394). Esta situación sirvió de experiencia básica y fue materia muy discutida en la tradición constitucional inglesa, incluso con anterioridad a la restauración, cuando se planteó el problema en relación con la noción de prerrogativa: ¿cómo resolver un conflicto entre el rey y el pueblo acerca de si la prerrogativa ha sido bien o mal empleada? ¿Quién asumirá la función de juez? Thomas Smith dejó el problema sin resolver (395), y Locke no fue tampoco más allá: "no puede haber juez en este mundo entre un poder ejecutivo en funciones, que hace uso de la prerrogativa, y un poder legislativo que depende de la voluntad de aquel para reunirse" (396), tesis que repetirá con insistencia (397). En este punto, Locke no sólo negaba la supremacía del poder legislativo sino que además no imaginaba ningún poder interpuesto, ni ninguna posibilidad de mediación que resolviera la situación: ausentes los poderes terrenales había que invocar al cielo. En última instancia, había que acudir al "de resistencia. Para Locke las posibilidades jurídicas ofrecían un repertorio limitado de soluciones, fuera de las cuales imperaban la fuerza y la "naturaleza" (398).

Los jueces no tenían por misión defender y garantizar la libertad política, sino la civil, esto es, la propiedad. En el orden penal la significación era la misma: reprimir los atentados al orden burgués y defender los derechos de la burguesía por los métodos legales más drásticos, por los punitivos (399). El sistema judicial burgués atiende a la víctima y no al reo, tiene un marcado carácter represivo y no garantizador.

Fue Montesquieu quien avanzó soluciones en este punto que, una vez más, no son de naturaleza jurídica, sino política. Se alude generalmente al pensador francés sólo para reproducir su famosa frase de que "el poder frene al poder", cuando en realidad no se refería Montesquieu a los tres poderes jurídicos, ni mucho menos, sino a las potencias políticas, a las fuerzas sociales. No se trata de un problema legislativo o constitucional, sino estrictamente social y político. Se trata de alcanzar un balance o equilibrio entre las dos clases en liza, la burguesía y la aristocracia terrateniente dentro del poder legislativo. Lo que trataba de resaltar Montesquieu es el papel político de la nobleza -su claseentre el rey y el pueblo, a la que reputaba el poder intermediario más natural, "que forma parte en cierto modo de la esencia de la Monarquía" y sin la cual, o se cae en el Estado despótico o en el Estado popular (400). El paso del lenguaje jurídico de los poderes al político de las potencias es evidente en la obra de Montesquieu: propone la traslación de las competencias políticojudiciales al Senado, convertido en una segunda cámara con facultades judiciales arbitrales. Montesquieu en este punto, a diferencia de Locke, no acude al cielo para resolver el posible conflicto y mucho menos al temerario derecho de resistencia, que Montesquieu aborda cautamente. En su lugar acude a la nobleza como fuerza política arbitral, cuya expresión jurídicoconstitucional es una segunda cámara legislativa con atribuciones 
jurisdiccionales, es decir, capaz de fallar litigios políticos. Esta es la clave de bóveda del pensamiento de Montesquieu.

Muy diferente será en este aspecto la concepción del doctrinarismo, cuyo núcleo jurídico es precisamente la configuración de un rey no integrado dentro del poder ejecutivo, sino por encima de todos ellos, como poder moderador $y$ arbitral entre los tres poderes. Para Benjamin Constant, el poder real es el "poder judicial de los otros poderes" (401) y parecidas concepciones expuso Tocqueville al criticar los sistema constitucionales mixtos. Según él existen dos intereses enfrentados, los de los "grandes" y los del pueblo; si el poder se reparte de modo uniforme entre ambos, esto es, al cincuenta por ciento, lo que se produce es el "gobierno mixto" propenso a la revolución o a la disolución: "Pienso, pues, que siempre hay que colocar en alguna parte a un poder social superior a todos los demás, pero creo la libertad en peligro cuando ese poder no encuentra ante sí ningún obstáculo que pueda contener su marcha y darle tiempo a moderarse a sí mismo" (402). Y más adelante, en otro pasaje, caracteriza precisamente a los tribunales del Antiguo Régimen el que dispusieran de competencias en materia política:

No sólo los tribunales de justicia decidían casi todas las querellas entre particulares; en gran número de casos, servían de árbitros entre cada individuo y el Estado.

No quiero hablar aquí, en absoluto, de las atribuciones políticas y administrativas que los tribunales habían usurpado en algunos países, sino de las atribuciones judiciales que poseían en todos. En todos los pueblos de Europa había, y todavía hay, muchos derechos individuales relacionados la mayor parte con el derecho general de propiedad, que estaban colocados bajo la salvaguardia del juez, y que el Estado no podía violar sin el permiso de éste.

Ese poder semi-político era el que distinguía, principalmente, a los tribunales de Europa de todos los demás; porque todos los pueblos han tenido jueces, pero no todos han dado a los jueces los mismos privilegios.

Si se examina ahora lo que ocurre en las naciones democráticas de Europa que suelen llamarse libres, igual que en las otras, se ve que, en todas partes, al lado de esos tribunales, se han creado otros más dependientes cuyo objeto especial es decidir excepcionalmente en las cuestiones litigiosas que pueden producirse entre la administración pública y los ciudadanos. Se le deja al antiguo poder judicial su independencia, pero se estrecha su jurisdicción, y se atiende, cada vez más, a no hacer de él más que un árbitro entre intereses particulares.

El número de esos tribunales aumenta sin cesar, y crecen sus atribuciones. El gobierno, pues, escapa cada día más a la obligación de hacer sancionar por otro poder sus voluntades y sus derechos. No pudiendo pasarse sin los jueces, quiere, por lo menos, elegir él mismo a sus jueces, y tenerlos siempre en su mano, es decir, que entre él y los particulares, coloca todavía la imagen de la justicia más que la justicia misma (403).

El garantismo judicial, para Tocqueville, es sinónimo de Antiguo Régimen, algo a superar en nombre del libre juego de las fuerzas sociales. El problema del balance y del equilibrio, por otra parte, sigue siendo en Tocqueville, de tipo 
político y no jurídico. Este último no es más que la articulación del primero, su consecuencia y no su punto de partida. Se sigue privando al poder judicial de todo protagonismo, siquiera en la esfera administrativa, y menos en la política, y se hace incapié en la superioridad de un "poder social" sobre todos los demás. Esa superioridad ya no radica en el legislativo ni el equilibrio está dentro de él, sino que es el ejecutivo, encubierto como poder "neutro" el que se situa por encima de los demás.

Esa fue la concepción prevaleciente en el liberalismo a lo largo de todo el siglo $X I X$ : el poder judicial es una pura construcción jurídica dotada de muy escasos poderes reales $y$, desde luego, ninguno en el plano político, ni siquiera el de mediación o arbitraje entre los demás poderes.

Esta misma idea es la que Carl Schmitt integra luego en su propio y original pensamiento, tan alejado, por otra parte, de estos postulados liberales. Según él, los conflictos políticos "no se pueden resolver ni con normas generales preestablecidas ni por el fallo de un tercero 'no partícipe' $y$, por consiguiente 'imparcial"" (404). Según este autor "las divergencias de opinión y diferencias entre los titulares de los derechos políticos de carácter decisivo o influyente no pueden resolverse, generalmente, en forma judicial, salvo en el caso de que se trate de sancionar transgresiones manifiestas de la Constitución. Dichas divergencias o bien son zanjadas por un tercero, situado por encima de los litigantes y revestido de un poder político más excelso -y entonces ya no se trata del defensor de la Constitución, sino del soberano del Estado; o bien son dirimidas o resueltas por un organismo que no es superior, sino coordinado, es decir, por un tercero neutral, un 'pouvoir neutre et intermédiaire', que no se halla situado por encima, sino al mismo nivel de los restantes poderes constitucionales, aunque revestido de especiales atribuciones y provisto de ciertas posibilidades de intervención" (405).

El poder judicial era neutro pero intermediario y, al elaborar su teoría políticoconstitucional, los doctrinarios no pensaron precisamente en el poder judicial para encarnar ese arbitraje neutro. La organización judicial era algo inocuo políticamente, de muy escaso interés $y$, al mismo tiempo, dúctil y de fácil instrumentalización, funcional al sistema político, adaptable y muy depediente de él. De ahí que no necesite alterarse con el cambio político, lo cual no solamente no es prueba de independencia sino, precisamente, de una cómoda dependencia. El sistema judicial es fácilmente utilizable sin necesidad de adaptarlo al cambio.

\subsection{Lo público y lo privado en la independencia del poder judicial}

La independencia del poder judicial no se plantea apenas en los orígenes del constitucionalismo $y$, desde luego, tiene muy poco que ver con su "autogobierno", que fue siempre una cuestión muy secundaria, cuando no ausente, sobre todo allí donde el sistema judicial se organizaba en base al jurado y a la electividad de los jueces. La Constitución francesa de 1791 no habla para nada de independencia, y la española de 1812 sólo se refiere a la "imparcialidad" en el art.279; ésta derivaba de la superioridad de los jueces sobre las partes, de su "auctoritas" y, en consecuencia, era relativa a la libertad civil, no a la política, de modo que sus relaciones con los otros dos poderes no 
eran, ni mucho menos, de independencia: un funcionario o agente gubernativo podía ser imparcial, pero desde luego, no era independiente. La organización judicial podía desarrollarse sobre bases comisariales u oficiales, pero el problema, para los primeros liberales, no radicaba aquí, en el estatuto del juez, sino en su origen, en su reclutamiento. Los jueces podían ser "oficiales" como en España o "comisarios" como en Francia, pero la cuestión era: ¿de quién o de quiénes eran comisarios los jueces? Si los jueces no eran independientes sino dependientes la pregunta correcta era, ¿de quién eran dependientes los jueces?

Abolida la justicia señorial, los jueces dejaban de resolver sobre sus propios intereses; se separaba lo público de lo privado, por lo que, por esto mismo, se dejaba de lado toda la problemática de la independencia. Cada cual sería juzgado por sus iguales, no por aristócratas o por servidores de los aristócratas, sino por ciudadanos iguales a él, por "jueces naturales" (art.247) con exclusión de los fueros privilegiados (art.248) pero siempre que se tratara precisamente de "negocios comunes", no en los demás. La sociedad se organizaba horizontalmente; la única jerarquía era la derivada del ejercicio de funciones públicas $y$, en el caso, de los jueces, eran de extracción del "tercer estado": superiores en sus funciones pero idénticos en lo demás. Por dos razones, por tanto, la independencia ni se planteaba: en los tribunales extraordinarios porque su razón de ser era, por tratarse de asuntos políticos, la dependencia precisamente, $y$ en los ordinarios tampoco había lugar a cuestionarse la independencia sino hasta el momento en que los jueces fuesen nombrados por el ejecutivo y entediesen en asuntos más allá de los "negocios comunes".

La independencia de los órganos judiciales no fue una consecuencia de la separación de poderes (406), porque en su concepción original sólo el legislativo era independiente, pero no ninguno de los demás. La separación de poderes se estableció para segurar la separación entre el Estado y la sociedad, la neutralidad del primero y la independencia de la segunda; no se refería a los derechos subjetivos civiles, sino a la libertad política, a la constitución, a la ley relativa a las cuestiones políticas, separadas éstas de las privadas. Los jueces son independientes de la sociedad porque son un poder público $y$, en consecuencia, separado y superior a la sociedad pero, precisamente por ello, dependiente del Estado o, por mejor decirlo, de los demás poderes del Estado $y$, especialmente, del legislativo. Si, como hemos dicho, éste era superior a los demás, era el único realmente independiente; los jueces carecían de voluntad propia; su voluntad era la de la ley, la del poder legislativo, frente al que más que dependientes eran "impotentes”, en expresión de Carré de Malberg (407).

Los jueces, bisagra entre el Estado y la sociedad, eran independientes de la sociedad a costa de su dependencia respecto del Estado; se sacrificó la independencia de los jueces a la separación entre el Estado y el sociedad.

No faltan autores que sostienen que el poder judicial era independiente precisamente porque carecía de voluntad propia, de representación política frente a los otros dos, que son poderes políticos "por antonomasia" (408). El poder judicial -afirman- es independiente precisamente por la separación de poderes, llegando a hablar aquí incluso de "aislamiento" (409) pero sin 
concretar, por una parte, si se trata de un aislamiento respecto de la sociedad o de los demás poderes del Estado y, por la otra, si el aislamiento significa independencia o, por el contrario, es indicio de total subordinación política.

La cuestión de la independencia es también una derivación de la problemática de la mediación jurisdiccional entre los poderes ejecutivo y legislativo; o en otros términos, la supuesta función atribuída a los jueces de garantizar los derechos y libertades ante las infracciones que se cometieran. Pero el papel mediador, como ya hemos expuesto, presupone atribuciones políticas tradicionalmente excluídas del poder judicial; y la función garantista, como función constitucional, no fue de su competencia, sino algo propio del legislativo.

Independencia y poder son términos correlativos, cuando tomamos el término poder en su sentido más estricto, en su acepción de competencia, fuerza o coacción. Si verdaderamente el poder judicial fuese un poder, sería independiente, pero no sucede así; al poder judicial se le priva de capacidad de ejecución directa y de competencias políticas, y esto no solamente reduce sensiblemente su radio de acción, sino que obstaculiza la demostración de aquello que se predica, a saber, su independencia, fallando en litigios políticos; si ésta función les está vedada, la cuestión de la independencia se transforma en un dogma, en una entelequia jurídica, tanto más increíble cuanto que se impide su verificación obstinadamente. Jurídicamente la independencia del poder judicial es un punto de partida, un axioma; pero desde la óptica política, es un punto de llegada, empíricamente constatable siempre que se den las premisas necesarias, esto es, siempre que disponga de competencias políticas.

Si retomamos la cuestión desde un punto de vista histórico, observaremos que bajo el feudalismo nadie disponía del monopolio de la jurisdicción, sino que existían funciones judiciales en manos "privadas" (si es que puede emplearse este término) o de los propios interesados (410). En tales circunstancias es absurdo pensar que el señor feudal impartiera justicia con independencia, sino todo lo contrario, sus facultades jurisdiccionales y coactivas eran una pieza esencial de la explotación clasista, por lo que Tocqueville llegó a decir que los tribunales señoriales habían sido "la gran rueda del gobierno feudal" (411). El señor feudal podía resultar imparcial -o no- cuando le correspondiera fallar los litigios particulares entre dos de sus vasallos, pero nunca si tuviera que hacerlo en un pleito en el que estuvieran en juego sus propios intereses, como apreciaron tanto Adam Smith (412) como Tocqueville (413).

La revolución incorpora al Estado todas las facultades jurisdiccionales pero, en definitiva, el Estado burgués no puede ser más independiente que el señor feudal respecto de sus propios intereses. Decía Maurice Hauriou que "las prerrogativas, como los privilegios, han sido desterrados de las relaciones sociales por la revolución, pero no lo han sido de las relaciones políticas; por el contrario, se han concentrado en las manos del Gobierno y de la Administración... La Administración Pública ha sucedido a las clases privilegiadas del antiguo régimen en el papel de gestor de negocios del público, que en otro tiempo estas clases habían cumplido mejor o peor; ella ha heredado, por lo mismo, sus prerrogativas" (414). 
El constitucionalismo no rompe con aquella concepción iusnaturalista que situaba al príncipe por encima de la ley. Históricamente se produce una subrogación, una continuidad de métodos perceptible en conceptos como el de prerrogativa. $Y$ además, las propias constituciones subordinaron el poder judicial encasillándolo dentro de un sistema político-jurídico del que sólo era una parte reducida. Locke lo había puesto de manifiesto al referirse a todos los poderes fiduciarios en general: "No es preciso que hablemos de otros poderes delegados y subalternos de una comunidad política -refirió- porque son tantos y tan infinitamente variados, de acuerdo con las costumbres y las constituciones de las diferentes comunidades políticas, que sería imposible tratar de una manera particular de todos ellos. Limitándonos a lo que concierne a nuestro propósito actual, bastará que digamos a este respecto que la autoridad de cada uno de estos poderes nunca sobrepasa a la que de una manera positiva se les ha otorgado o conferido por delegación y que todos ellos son responsables ante algún otro poder de la comunidad política" (415). Más concretamente en relación con los tribunales, escribirá más tarde Tocqueville: "En todas las naciones organizadas de Europa, el gobierno ha mostrado siempre una gran repugnancia a dejar a la justicia ordinaria solucionar cuestiones que le interesaban a él mismo. Esa repugnancia es naturalmente mayor cuando el gobierno es más absoluto. Por el contrario, a medida que la libertad aumenta, el círculo de las atribuciones de los tribunales va ampliándose, pero ninguna de las naciones europeas ha pensado todavía que cualquier cuestión judicial, fuese el que fuese su origen, pueda ser abandonada en manos de jueces de derecho común... En las naciones de Europa los tribunales no tienen más que a los particulares como justiciables" (416).

El Estado delimita un marco que el poder judicial no puede desbordar; éste se subordina a aquel como la parte al todo, está sujeto a unos límites; está sometido a la ley precisamente, y no a la costumbre ni a la jurisprudencia: "La independencia judicial -en expresión de Carl Schmitt- no es más que el reverso de la sujeción del juez a las leyes" (417). En términos algo parecidos ha escrito hoy Fairén Guillén que "el reverso de la actividad independiente del Juez como tal, es su situación como funcionario del Estado" (418). Es algo, pues, intrínsecamente contradictorio y muy discutido en su momento(419) porque la norma aplicable en la época de la revolución no era ya algo ya existente, usual y tradicionalmente observado, sino que la burguesía separó radicalmente la creación de la aplicación del Derecho, y el Derecho que los jueces deben aplicar es un Derecho creado.

La ley en el constitucionalismo es algo muy preciso y concreto que rompe con lo anterior radicalmente y que va acompañada de otros mecanismos jurídicos ("référé legislatif", Tribunal Supremo, etc.) cuyo objetivo es disciplinar al juez estrechamente. Existe una subordinación muy mecánica y rígida en el primer constitucionalismo, subordinación que, en última instancia, es de tipo político: el Estado, por medio de las normas legales, define la funcionalidad que debe desempeñar el sistema judicial en todos los órdenes sociales, económicos, políticos, culturales, etc.

La vinculación de los jueces a la ley, sin embargo, es sólo una de las fuentes de dependencia política: los jueces, ciertamente, están sometidos a la ley, pero no única y exclusivamente; concurre también una influencia política directa, 
sociológica o "de facto" que se puede obviar con la excusa de un formalismo estéril y que se deriva del propio proceso de reclutamiento de los jueces, y de ahí los distintos sistema ideados en función de distintos intereses, desde la elección hasta la designación directa por el ejecutivo. En la aplicación de la ley no se puede prescindir de la persona del juez, de su extracción social, económica, social y cultural, quien asume funciones que están muy lejos de ser impersonales, mecánicas (420) o unívocas. La legalidad no es omnicomprensiva, ni tiene un significado unívoco, ni es posible un círculo completo que abrace toda la actividad del Estado, en su extensión y, sobre todo, en su proceso de gestación: no se puede reglar desde la decisión política orginaria hasta sus últimas secuelas. No es posible ni conveniente; incluso en un ámbito tan exigente, como el penal, se crearon en Francia Altos Tribunales, habiendo hecho referencia Laski a la necesidad o la oportunidad de sustituir el criterio jurídico por el político en la toma de decisiones. Para Laski "existen tipos de delitos, el de sedición por ejemplo, en cuyo caso sólo pueden formularse las decisiones no partiendo de principios, sino aplicando motivos de oportunidad" (421). Y lo mismo ha expuesto la doctrina en alusión a los juicios de responsabilidad criminal de los ministros y altos cargos políticoadministrativos (422).

A través de la ley se establece una clara relación jerárquica entre el Estado y los jueces. Es insostenible afirmar que en el ejercicio de sus funciones los jueces no están organizados dentro sino fuera del Estado (423), como el general que en plena batalla está fuera del ejército. Se ha llevado la cuestión de la independencia judicial a unos niveles que, lo mismo que a los príncipes del siglo XVIII, hay que situarlos fuera del mundo incluso, porque parece que, de lo contrario, no serían jueces, sino seres mortales contaminados como todos los demás de defectos, inclinaciones, prejuicios e ideología (424). Si la persona del rey era sagrada, no han faltado teorías acerca del carácter sacerdotal de la función judicial (425).

Si el aislamiento judicial es imposible hay que preguntar: independencia ¿respecto de qué o de quién? La independencia se puede -y se debeexaminar, en primer lugar, respecto del Estado y de los demás poderes del Estado; pero si el poder judicial no es en realidad tal poder, resulta no sólo que no puede ser independiente, sino que es dependiente, que está supeditado a los demás poderes para cumplir su función. Y esto con tanta más razón cuando el objeto procesal es el propio Estado o alguno de sus poderes. Villar Palasí ha reconocido que "la Administración abdica difícilmente de privilegios, no baja definitivamente de su trono al terreno de los particulares; se limita a solamente a descender algunos peldaños" (426). El "judicialismo" fue algo efímero en países como España, en los que se trató de imponer, porque significaba desnudar a la Administración de "auctoritas", situarla al mismo nivel que los particulares, situación que nunca se ha vuelto a reproducir, sino todo lo contrario; progresivamente los privilegios de la Administración no han hecho sino extenderse y reforzarse. La Administración, decía Maurice Hauriou, "de ningún modo está sometida a la autoridad del juez de la misma manera que los particulares. Consiente en someterle sus diferencias con los administrados, pero puede decirse que con él trata de potencia a potencia” (427). 
Por otro lado, esa dependencia respecto del Estado no es sólo hacia ese ente neutro e impersonal del que hablaban los liberales, sino que existen tantos tipos de Estados como regímenes políticos, y de ellos es indirectamente -a veces directamente- tributario el sistema judicial. "Político no es igual que estatal -escribe Lucas Verdú- pero el Estado es una realidad política, la más significativa; el Estado es una institución política capital. La mayor parte de los actos políticos se refieren al o revierten sobre el Estado" (428). La neutralidad del Estado -y el carácter formal de su constitución- en las primeras ideas liberales, es la proyección del capitalismo como primer modo de producción capaz de extraer plusvalía sin necesidad de coacción o fuerza exterior a la relación laboral privada. Pero parece claro que esta noción es insostenible, que el Estado no es neutro ni puramente funcional, que la difusión de esta concepción no fue más que "un arma especialmente útil en la lucha política" (429) de la burguesía en los comienzos de su revolución. El Estado tiene un carácter político determinado, y la supeditación de los jueces dentro del aparato del Estado es una supeditación también al sistema político concreto que el Estado defiende y representa. Hay, por tanto, una vinculación de la organización judicial a un sistema político concreto a través del propio Estado, ya que uno y otro -Estado y sistema político- se pueden distinguir pero no separar. En una situación determinada, como la de España en 1812, con el país dividido en "afrancesados", por un lado, y resistentes, por el otro, divididos estos a su vez en serviles y liberales, la función del juez, desde el primero hasta el último, fue muy clara y definida; no solamente la ley les obligó a defender a un partido, sino que se exigieron pruebas de adhesión al partido liberal para poder acceder al empleo.

Así, el art.ll del Decreto de 9 de octubre de 1812 decía que si alguno de los jueces y magistrados "no mereciesen la confianza del Gobierno, y formado expediente pareciesen fundados los motivos, podrá suspenderle o suspenderles oído el Consejo de Estado, y hará pasar inmediatamente el expediente al Supremo Tribunal de Justicia para que juzgue con arreglo a las leyes". El de 8 de junio del mismo año establecía los requisitos para acceder al empleo de juez, destacando entre ellas, la de ser adicto a la Constitución y "haber dado pruebas en las circunstancias actuales de estar por la independendencia y la libertad de la Nación". El art.4 del Reglamento del Tribunal Supremo de 13 de marzo de 1814 decía que todos los magistrados del Tribunal debían reunirse "en una sala para oir las órdenes que el Gobierno comunicare al Tribunal". El art.7 del Capítulo II de este Reglamento obligaba al presidente del Tribunal a dar a conocer al pleno las "órdenes" del gobierno, y en parecidos términos, el Decreto de 17 de abril de 1812 sobre condiciones para ser magistrado del Tribunal Supremo. "La potestad judicial -ha afirmado Villar Palasí- había surgido en la misma Constitución como un poder separado pero no de modo total, ni desde luego configurándolo como un freno $y$ contrapeso a la potestad de la Administración. Al recibir las ideas francesas a comienzos de 1800, ni en el campo general, ni en el peculiar de la Administración lo judicial alcanzó el rango de poder dividido" (430).

Pero no solamente hay subordinación al sistema político, sino también al económico y a todos los demás elementos configuradores del Estado burgués moderno. Como decía Adam Smith "el gobierno civil, en cuanto instituído para asegurar la propiedad, se estableció realmente para defender al rico del pobre, 
o a quienes tienen alguna propiedad contra los que no tienen ninguna" (431). En parecidos términos, Hegel contraponía la "universalidad de la libertad" a la "particularidad de la propiedad" que como derecho "no está, sin embargo, ya sólo en sí, sino en su realidad efectiva vigente, como protección de la propiedad por medio de la administración de justicia” (432). En el capitalismo, apuntó por su parte Carl Schmitt, "por orden jurídico es preciso entender un orden jurídico burgués basado en la propiedad privada y en la libertad personal, y considerar al Estado como la garantía armada de este orden, paz y seguridad burguesa" (433).

La dependencia del sistema judicial respecto del Estado y de los poderes del Estado está en función tanto de los intereses sometidos a decisión jurisdiccional, como del singular posicionamiento del Estado en tanto que parte afectada por dicha decisión. Cuando es el Estado y los poderes del Estado los que o bien constituyen la materia procesal, o bien son parte del proceso, no hay ni puede haber independencia ninguna en absoluto porque en realidad el sistema judicial forma parte (434) de eso mismo que se juzga, y la parte, como ha quedado expuesto, se somete al todo y no a la inversa. Procesalmente el Estado puede ser parte en un litigio, pero no se desprende -ni puede desprenderse- de su posición de "imperium", incluso frente a un órgano que también dispone de "imperium" pero únicamente con respecto a los particulares (435).

No hay independencia cuando es la existencia misma del Estado lo que constituye la materia procesal. El sistema judicial no está fuera del Estado, es una parte de él y está supeditado al poder político. "No es en absoluto concebible -afirmaba Carré de Malberg- que un tribunal, cualquiera que sea, limite por su propia iniciativa la potencia dominadora del Estado: sólo el Estado, actuando por su órgano supremo, puede imponerse tales limitaciones que les igualaría a las más altas autoridades estatales. Por todas esas razones, el poder creador de los jueces en la esfera del derecho público permanece, en suma, bastante restringido" (436).

En contra de estas tesis, Montero Aroca ha escrito: "A jueces y magistrados se atribuye, pues, una potestad de derecho público, caracterizada por el 'imperium' derivado de la soberanía, lo cual les coloca en situación de superioridad respecto de las personas que con ellos se relacionan. Actuando jurisdiccionalmente el juez no tiene superiores ni iguales, todos están bajo su potestad" (437). Entendemos que este es un razonamiento puramente especulativo que la historia se encarga de desmentir, porque la parcela de poder que les corresponde suele ser más bien exigua y reducida. Pero donde más se aprecia el error de este tipo de concepciones es, una vez más, en el momento de ejecutar las resoluciones, en el momento de tener que recurrir a la coacción y a la fuerza. Para Duguit el Estado garantiza la observancia del Derecho que se aplica a personas distintas de los gobernantes; pero el Derecho Público es el Derecho del Estado, el Derecho de los gobernantes y, por consecuencia, no se puede concebir un modo de sanción directa contra el propio Estado: "Ninguna disposición de Derecho Público -añade Duguit- que crea obligaciones de Derecho Público a cargo del Estado, puede ser sancionada directamente por la compulsión, puesto que el Estado, dueño de la compulsión, no puede ejercerla directamente contra sí mismo. De ahí resulta 
que las disposiciones de Derecho constitucional en el sentido amplio explicado precedentemente, están desprovistas de formas de sanción directa" (438). Loewenstein ha subrayado también los riesgos de la justicia política: sus resoluciones podían no ser respetadas (439), ya que no pueden emplearse contra los órganos superiores del Estado los medios coactivos ordinarios (440). Aunque la decisión judicial sea contraria a un interés o criterio sustentado por la Administración, todo puede quedar en una mera declaración de buenas intenciones. La ejecución de las decisiones "políticas" de los jueces está en función del propio órgano perjudicado por la resolución.

Los poderes cuasi-nominales, entre ellos el judicial, dependen de los anteriores y deben acudir en demanda de su auxilio a fin de se cumplan sus resoluciones. Esta dependencia material de los jueces frente a la Administración es sumamante significativa, aún para Jellinek, quien opinaba que el Derecho se sustentaba más que en la fuerza, en la convicción de su obligatoriedad. Esta convicción -sostenía Jellinek- es muy diferente en el Derecho público que en el privado, para el ciudadano particular al que se le impone obediencia que para el Estado, que es quien crea la norma jurídica. Para Jellinek aquí estaba la clave: el mismo que produce la norma debe cumplirla, ya que la obligatoriedad del Derecho sólo pueden garantizarla en última instancia poderes exteriores (441). El Derecho Público no tiene garantía de eficacia.

Con relación a los demás poderes del Estado es, pues, evidente que no existe la relación de superioridad a la que se refiere el profesor Montero Aroca. Y no solamente no hay tal superioridad, sino que lo que se da es una verdadera dependencia.

La distinción ni es novedosa ni data de ahora. Ya Bacon escribía: "El oficio de los jueces puede referirse a la parte demandante, a los abogados defensores, a los escribanos y ejecutores de la justicia que están bajo ellos y al soberano o Estado que está sobre ellos" (442). Hay que pasar, por tanto, a examinar la cuestión de la independencia cuando se trata de intereses privados o de un interés político secundario, o bien cuando los justiciables son los particulares. Entonces la posición de los órganos judiciales cambia bastante radicalmente. Cuando se trata de intereses privados o de particulares sí es posible independencia, porque hay -o puede haber- una relación de superioridad del órgano competente con relación a la materia procesal y a las partes interesadas. La distinción entre el Derecho público y el privado descansa, como observó Kelsen, en la distinción entre las relaciones iguales y las jerarquizadas (443). En este último caso, los justiciables no están en el mismo plano, y conviene conocer cuál es exactamente el plano del juez. Pero entre particulares la situación es distinta: desde los orígenes del constitucionalismo el Estado ha asumido las funciones judiciales, antes privatizadas. El Estado burgués, como hemos visto, a diferencia de los modos de producción anteriores, es una fuerza situada por encima de la sociedad, que se desentiende de los litigios episódicos y coyunturales porque uno de sus objetivos es precisamente amortiguar y reducir el impacto de los conflictos sociales, políticos, económicos, etc. hasta el punto de que, por excepción, hay periodos históricos en que los antagonistas en liza están tan equilibrados que el poder del Estado, como mediador aparente, adquiere cierta independencia momentánea respecto a unos y otros. 
La independencia del poder judicial adquiere algún sentido cuando es posible mantener ese alejamiento entre el Estado y la sociedad, y no se trata más que de eso precisamente, de la independencia de la sociedad, no de la de los jueces. Por otra parte, de ese modo se consigue también que el Estado se sobreponga a los conflictos individuales, evite la agudización de las contradicciones en interés del mantenimiento del sistema socio-político en su conjunto. Sólo cuando este mismo sistema institucional, cuya salvaguardia es tarea fundamental del Estado, está en peligro, es cuando hay una relación de superioridad del órgano judicial respecto a las partes, nunca cuando esas relaciones son de igualdad o de subordinación, que son las que mantienen el poder judicial con otros aparatos del Estado y con el Estado mismo. Duverger ha puesto de relieve esta duplicidad funcional de los órganos judiciales ante asuntos privados y públicos. Según el autor francés "la aplicación del principio de legalidad es más o menos riguroso" en función de la independencia de los jueces; pero en realidad independiente es sólo el parlamento, y "la existencia de tribunales independientes no coincide exactamente con la democracia liberal", ya que hay tribunales independientes en regímenes anti-liberales, y hay democracias liberales, como Francia, donde "la independencia de los magistrados es limitada" (444).

Las desigualdades extraprocesales, políticas, sociales, económicas, culturales, etc., se concretan siempre en el interior mismo del proceso, bien de manera expresa o bien tácita. El proceso tiene, sin embargo, una consideración secundaria (445) y deviene político cuando la actividad del Estado se convierte en objeto de litigio. Desde el punto de vista político -y esto es lo definitivo- es el sistema judicial el que forma parte del Estado, y no al revés. La ley procesal opera tanto multiplicando la desigualdad fáctica, como pretendiendo igualar formalmente a quienes son desiguales materialmente. Si este último fenómeno es obvio, por lo que no insistiremos en él, sí interesa, en cambio, poner de manifiesto el otro aspecto: la ley procesal como multiplicadora de las desigualdades materiales, en sus dos vertientes tradicionales, discriminaciones "ratio materiae" y discriminaciones "ratio personae". En ambos casos, la ley procesal no prima al perjudicado por la desigualdad material, sino que ahonda el distanciamiento social y político. Por tanto, no sólo por la materia debatida, sino que también en función de las partes (446), la organización judicial presenta un marchamo de clase aún más acabado, y establece normas bien diferentes según el carácter del justiciable, según, en definitiva, si el inculpado es un antagonista o un servidor del Estado, o el propio Estado.

Este fue el caso del Tribunal Extraordinario de Vigilancia y Protección, creado por la Junta Central en 1808, competente para los delitos contra la seguridad del Estado y, al mismo tiempo, para tutelar a "los que siendo buenos servidores del Rey y verdaderos españoles se vean censurados por un falso celo" (447). En España incluso en aquellos asuntos en que sin peligrar la existencia misma del sistema político, éste pudo verse afectado en la persona de alguno de sus integrantes o agentes, las normas legales disciplinaron la intervención de los tribunales comunes afin de que respondieran a las expectativas previstas de defensa del régimen establecido. 
La acción jurisdiccional, en consecuencia, está concebida como parte integrante del sistema político y para reforzarlo. El capitalismo es la propiedad privada y los jueces son su garantía.

La independencia no se puede estudiar aisladamente y sin relación alguna con los intereses que se someten al conocimiento de los órganos judiciales $y$, por otra parte, sin conexión alguna con el carácter de las partes implicadas. La organización judicial y su funcionamiento -el proceso- están fuertemente condicionados por ambos factores. El poder -y específicamente, el poder judicial- tiene un doble componente, como ha puesto de manifiesto Ferrando Badía, de modo que no solamente se proyecta hacia el exterior para imponer sus decisiones, sino que además se protege y defiende de las acciones provenientes del exterior, y por ello se rodea de prerrogativas y privilegios de los que carecen los demás (448).

La independencia del poder judicial aparece en la literatura jurídica precisamente cuando los jueces son más dependientes, cuando más estrechamente comienzan a ser sometidos por el gobierno, cuando más burocratizados se encuentran y, finalmente, cuando empiezan a conocer de materias administrativas y políticas, cuando comienzan a tener que adoptar decisiones políticas que afectan más próximamente al poder. Se empieza a hablar de independencia de los jueces cuando los jueces son menos independientes: la independencia nace y se nutre como ideología y sin más pretensiones que las ideológicas, a fin de encubrir una situación radicalmente opuesta.

Fueron los doctrinarios quienes comenzaron a desarrollar esta ideología. Constant era decidido partidario de que los jueces fueran nombrados directamente por el rey (449) y, según él, aquí radicaba precisamente su independencia. Por contra lo que atentaba a la independencia de los jueces era precisamente tanto la elección popular como el nombramiento temporal: "En una monarquía constitucional -sostenía Constant- hay que dar al poder real toda la influencia e incluso toda la popularidad que la libertad comporta. El pueblo puede equivocarse frecuentemente en la elección de los jueces. Los errores del poder real son necesariamente menos raros: no hay ningún interés en cometerlos" (450). Estamos pues exactamente en las antípodas de 1789 en lo que a la forma de organizar el sistema judicial se refiere; surge el mito de la independencia de los jueces cuando los jueces son menos independientes que nunca.

\subsection{El supuesto papel de los jueces como garantes de los derechos y libertades fundamentales}

Ha quedado ya expuesto que el problema de la mediación y el de la independencia del poder judicial están estrechamente relacionados con otro: el relativo a su supuesta función garantizadora de las libertades fundamentales.

En la cuestión de las garantías, lo mismo que al hablar de la independencia, hay que diferenciar siempre lo público de lo privado, las libertades públicas de los derechos civiles. Las primeras no son derechos subjetivos, sino formas de participación e intervención política, concebida en términos genéricos y de clase; su núcleo, el "derecho" de sufragio, tenía un marcado carácter clasista, 
tanto en su vertiente activa, los electores, como pasiva, los elegibles. A diferencia de este área, los derechos civiles sí eran derechos subjetivos, articulados en torno a la propiedad privada, objeto de la ley y, por tanto, de la intervención judicial. Es esclarecedor recordar que cuando Flórez Estrada preconizaba un "gobierno justo" lo caracterizase precisamente como aquel en donde "la ley protegiese igualmente al pobre que al poderoso, y en donde sólo se persiguiese al delinqüente" (451).

Ahora bien, si la defensa de la constitución implica la identificación de una fuente de riesgo, esa fuente era -además del rey y los funcionarios- el propio poder judicial: "La previsión de las Leyes 7-14 de octubre de 1790 evidencia claramente que las Cortes constituyentes y sus sucesoras no habían pretendido la protección del individuo sino la protección del poder contra las censuras del juez" (452). El legislativo aparece como el auténtico órgano garantizador, tanto frente al ejecutivo como frente al judicial: "El Estado legislativo parlamentario -apuntó Schmitt- no conoce por principio garantías jurídicas materiales, porque confía incondicionalmente en el Parlemento como legislador ordinario" (453).

La exigencia de garantías no surgió simultáneamente a los "derechos" y libertades; sin embargo, para Ihering, si la utilidad es la esencial del Derecho, la garantía es su forma: "Los derechos son intereses jurídicamente protegidos" (454). Pero ésta era ya una concepción bien distinta de los derechos y libertades anteriores y superiores al pacto social, de los que hablaban los primeros liberales. Era un sistema jurídico en el que los "derechos" naturales se situan ya al mismo nivel de los derechos civiles, o por debajo incluso. El primer constitucionalismo no legisla sobre las libertades públicas, sino que las declara y reconoce antes, o como máximo, en el preámbulo de la propia constitución (455).

De aquella situación a la aparición de las garantías va por medio un largo proceso de gestación, a lo largo del cual se constató la escasa fidelidad constitucional: no bastaba reconocer un repertorio de derechos para que estos pudieran operar cotidianamente. Las garantías no nacen de las libertades, sino de su fracaso para abrirse camino por sí mismas; es la constatación de que ninguna norma "se protege o salvaguarda a sí misma, ninguna validez normativa se hace valer por sí misma" (456), sino que son necesarios, en términos de Jellinek, "poderes exteriores".

Jellinek dividió las garantías en sociales, que son aquellas mismas fuerzas (culturales, morales, religiosas, etc.) que cran el Derecho, lo influyen y aseguran su vigencia. En segundo término estaban las garantías políticas, la más importante de las cuales era, decía Jellinek, la división de poderes "meramente mediante su existencia". Y finalmente contaba las garantías jurídicas, entre las que enumeraba las distintas formas de fiscalización (parlamentaria, financiera, política, administrativa), la responsabilidad de las autoridades y sus agentes, los medios jurídicos (derecho de petición) y finalmente la jurisdicción, respecto de la cual, manifestó: "En la extensión de la jurisdicción al campo del Derecho Público se ha de ver uno de los progresos más importantes de la construcción del Estado moderno en el curso del siglo XIX" (457). Pero en los orígenes del constitucionalismo burgués la cuestión es 
clara: los jueces no garantizaban las libertades constitucionales frente al legislativo o al ejecutivo; por el contrario, eran ellos mismo un peligro a prevenir $y$, desde el punto de vista técnico, esas libertades eran "naturales" o anteriores al Derecho positivo, y no leyes que pudieran aplicar los tribunales (458). Las libertades fundamentales eran las obligaciones del legislador; sólo a él vinculaban y sólo el debía tutelarlas. Estaban por encima del poder constituyente; eran de una rigidez absoluta: inviolables, imprescriptibles, inalienables, etc. No eran los revolucionarios, sino los reaccionarios quienes pretendían legislar sobre libertades políticas, a fin de limitarlos y añadir "deberes"; si los derechos no eran compensados con los deberes, serían ávidamente acogidos por el pueblo, lo que, a falta de límites expresos, conduciría a la igualdad. El estado de naturaleza era un estado igualitario: no se puede "declarar" en toda su extensión, decían Malouet y Landine, sin tomar precauciones, sin señalar antes los límites, sin "las modificaciones del Derecho positivo" (459).

El carácter clasista de los derechos "del hombre y del ciudadano" (460) es algo que no intentaron disimular los primeros constituyentes. Los "casos de Corte" (461), por los cuales los órganos judiciales superiores asumían competencia en determinadas causas dirigidas contra aristócratas, fueron abolidos rápidamente en nombre de la neutralidad del Estado frente a la sociedad (462). El entramado jurídico de derechos lo que pretendía era preservar la propiedad privada, el régimen de explotación capitalista. Todo gira en torno a este núcleo central. Los derechos no eran "del hombre y del ciudadano" sino de la burguesía (463); y además, sus derechos significaban la privación de derechos para los demás: los derechos eran de todos los ciudadanos, pero había algunos (menores, mujeres, vagabundos, domésticos, dependientes) que no eran ciudadanos(464). Los derechos políticos, decía Sieyes, consisten en la participación en la elaboración de la ley, y son los únicos "que imprimen al ciudadano la calidad de representable" (465). Para Constant, "los derechos políticos consisten en ser miembro de las diversas autoridades nacionales, ser miembro de las autoridades locales de los parlamentos, y a concurrir a la elección de esas diversas autoridades" (466), y luego pasaba a examinar los derechos individuales "independientes de toda autoridad política" (467), enumerando la libertad personal, la religiosa, de industria, de propiedad y de prensa. La Declaración de Derechos de Maryland afirmaba: "Todos los hombres que tengan propiedad, un interés común y una vinculación a la comunidad, tendrán derecho de sufragio"; la de New Jersey exigía un patrimonio de al menos cincuenta libras y "un estado claro"; y en parecidos términos se expresaban las demás declaraciones americanas. El art.8 de la Constitución termidoriana exigía pagar "una contribución directa, fundiaria o personal" para poder ser considerado ciudadano francés.

En España la situación no era distinta. Basta leer los arts.5 (quiénes son españoles) y 18 (quiénes son ciudadanos) de la Constitución de 1812 para hacerse una idea de ello, por no recordar que los esclavos y mulatos ni siquiera alcanzaban la categoría de españoles: había que tener "mucho cuidado", decía el Discurso Preliminar, con "el inmenso número de originarios de Africa establecidos en los países de Ultramar, sus diferentes condiciones, el estado de civilización y cultura en que la mayor parte de ellos se halla en el día" (468). El art.23 de aquella primera Constitución española, decía: "Sólo los que sean 
ciudadanos podrán obtener empleos municipales, y elegir para ellos en los casos señalados por la ley"; el art.27 restringía las elecciones para diputados a Cortes a los ciudadanos precisamente; el art.25 suspendía del ejercicio de la ciudadanía a los sirvientes domésticos, a quienes no tuvieran empleo fijo, oficio o modo de vivir conocido; y así sucesivamente. En el propio Discurso Preliminar se dejaba clara constancia de la íntima conexión entre ciudadanía y burguesía: "Nada arraiga más al ciudadano y estrecha tanto los vínculos que le unen a su Patria como la propiedad territorial o la industrial afecta a la primera" (469) y, consecuencia de ello es que "en un Estado libre puede haber personas que por circunstancias particulares no concurran mediata o inmediatamente a la formación de las leyes positivas" (470), por lo que cabe un "Estado libre" con la libertad restringida a sólo una parte de la población. La libertad, escribió luego Borrego, se ha hecho tan opresora para el pueblo como lo fue antes la tiranía; el nuevo sistema político lo había dejado "aislado" y sin representante (471). Para Juan Miguel de los Ríos, la propiedad es el fundamento de la independencia de las personas, por lo que sólo los propietarios pueden ejercitar los derechos cívicos (472).

Por más que este aspecto capital de la mitología de los derechos "humanos" se haya pretendido encubrir con un manto ideológico impermeable, el recurso a las fuentes históricas es absolutamente desmitificador, especialmente cuando se llega al capítulo de la igualdad. Para el mismo Montesquieu, la igualdad es algo que se debe emplear de manera muy dosificada, incluso en los Estados "democráticos", de modo que "toda la desigualdad en la democracia debe dimanar de la naturaleza de la democracia y del principio mismo de la igualdad" (473). Según Tocqueville "la igualdad aisla y debilita a los hombres" (474). Sin necesidad de plantear a la burguesía el -para ella- espinoso problema de la igualdad, no faltan tampoco otros reconocimientos explícitos de clasismo de los derechos "humanos". Los mismos pensadores liberales lo expusieron sin ninguna mixtificación: "No conozco más que dos maneras -escribió por ejemplo Tocqueville- de hacer reinar la igualdad: hay que conceder derechos a cada ciudadano o no dárselos a nadie" (475). No podía ser de otra manera: la quiebra del igualitarismo era esencial para la construcción del Estado, como ha expuesto Bartolomé Clavero (476).

De modo que la vulgarización acerca del carácter de las libertades públicas no está en las fuentes de la época, sino que ha sido algo re-escrito con posterioridad. El sistema de libertades burguesas lo que pretendía era preservar y salvaguardar la propiedad, el libre desenvolvimiento de la iniciativa individual, el mercado y la concurrencia mercantil (477). Y aquí ninguna función estaba encomendada a los jueces, cuya misión radicaba en dilucidar los litigios del mercado, los conflictos de los particulares entre sí. Pero en este reducido ámbito de lo privado no puede hablarse de derechos ni de garantías, sino meramente de contratos privados, regidos por el principio de la "autonomía de la voluntad", por el Derecho Civil: "La fuerza de los tribunales ha sido en cualquier tiempo -observaba Tocqueville- la mayor garantía que se pueda ofrecer a la indepdencia individual, pero esto resulta sobre todo verdad en los siglos democráticos; los derechos y los intereses particulares están siempre en peligro en ellos, si el poder judicial no aumenta y no se extiende a medida que se igualan las condiciones" (478). Los jueces resolvían los litigios de los compradores y vendedores, de los arrendadores y arrendatarios, de los 
prestamistas y prestatarios. Pero nada de esto tenía ninguna relación con las garantías: éstas dependían de una superestructura política regulada constitucionalmente que impedía al Estado intervenir en el mercado. $\mathrm{Y}$, en segundo lugar, dentro del propio ámbito de lo público, tampoco tenían los jueces competencia alguna, ya que esto sólo recientemente ha ido generalizándose, rebajándose los derechos "naturales" al nuvel de los derechos subjetivos legales.

Tal era el primitivo sistema burgués: primacía de los criterios emanados del legislativo, identificación de éste con la burguesía a través de un sufragio convenientemente dispuesto, elecciones indirectas, sufragio censitario, mandato no imperativo y todo un entramado político mecánicamente sujeto a la ley que, no solamente por su origen, sino por su destino también tiene un fin preciso: hacer que el peso político se desplace del Estado a la sociedad, que la influencia en el seno de ésta se corresponda con la influnecia en el seno de aquel. La influencia de la aristocracia, decía Sieyes, es artificial e impuesta, mientras que la que deriva de la propiedad es natural (479). "La ley debe proteger la libertad pública e individual contra la opresión de los que gobiernan", decía el art.9 de la Declaración de Derechos de los jacobinos. Un impulso de legitimidad emando de la nación -identificada con la burguesía- y un destino final de la acción pública, el "interés general", que no es otro que la plusvalía y el beneficio privado. Coronando el edificio el "defensor de la constitución" y de la legalidad, un órgano garantista por esencia porque éste sí que estaba más en la sociedad que en el Estado: el parlamento, el oráculo de la clase: "Se ha establecido la existencia del legislador -decía Sieyes- no para conceder, sino para proteger nuestros derechos" (480).

Si se padecía lesión de determinados derechos, había que recurrir a la cámara legislativa en reclamación, y de ahí la importancia del derecho de petición, contenido ya en el "bill of rights" de 1689; y el art.32 de la Declaración jacobina de 1793 estipulaba: "El derecho de presentar peticiones a los depositarios de la autoridad pública no puede ser, en ningún caso, prohibido, suspendido o limitado". Con un carácter algo distinto, el art.373 de la Constitución de Cádiz reconocía el derecho de representación ante las Cortes o el rey para reclamar la observancia de la Constitución. También el artículo anterior reconocía el papel del Congreso para hacerse eco de las infracciones constitucionales que le hubieren expuesto, a fin de que las remediara e hiciera efectiva la responsabilidad del infractor (481).

Lo que los jueces aseguraban y garantizaban era la propiedad, esto es, la "libertad civil" a que se refiere continuamente el Discurso Preliminar de Cádiz, así como el art.4 del texto fundamental: "La Nación está obligada a conservar y proteger por leyes sabias y justas la libertad civil, la propiedad y los demás derechos legítimos de todos los individuos que la componen". La libertad civil está claramente diferenciada de la libertad política, y la potestad judicial se separaba de las demás a fin de que los jueces no invadieran la reserva de ley, no pudieran interferir en la libertad política de los ciudadanos y, también a la inversa, para no mezclar lo público con lo privado, para que la política no se inmiscuyera en la propiedad, cuestión reiteradamente expuesta por Montesquieu, para quien no debían regularse por leyes políticas cuestiones que son de Derecho civil (482). 
La independencia judicial significaba eso cabalmente: si los jueces debían resolver los conflictos privados, su independencia trataba de mantener ese ámbito de intimidad al abrigo de la autoridad pública. No se trataba, pues, tanto de su propia independencia, sino de la de los ciudadanos respecto al Estado. Se trataba de impedir que la propiedad estuviera a merced de vicisitudes políticas.

La libertad civil consistía, pues, en la propiedad y la seguridad personal, en las leyes civiles y penales. Comprendía tanto la libre disponibilidad patrimonial como la protección frente a atentados de terceros. Aseguraba al propietario la libertad de movimientos e intimidaba al posible agresor con el arma punitiva. La ley penal no era nada en sí misma, sino la sanción de las demás, en palabras de Rousseau (483), una secuela y continuación de la ley civil, una parte del Derecho privado que la revolución había "nacionalizado". La ley debía proteger y garantizar los derechos burgueses tanto frente a la Administración como frente a perturbadores individuales.

La inexistencia de función garantista alguna del juez se prueba con claridad en la regulación del proceso penal y, más concretamente, en la forma como se articula la defensa en su interior; es decir, si se trata de un proceso inquisitivo o acusatorio, si el inculpado es objeto o sujeto del proceso penal. Basta una somera ojeada por la legislación del siglo XIX español para comprobar que, al margen de las reformas orgánicas y de los principios generales de la Constitución de 1812 (muy especialmente las visitas a las cárceles), nada cambió del proceso inquisitivo medieval, ni siquiera en la Ley de Enjuiciamiento Criminal de 1872, que se trataba no de un "código", sino de una "compilación", esto es, de una mera sistematización de la legislación dispersa anterior: "En la primera etapa, la aspiración del fuero único persigue introducir claridad en la Administración de justicia -escribe Montero Aroca- no se descrubre en ella aún camino para garantizar mejor los derechos y libertades de los ciudadanos"; se trataba, según Montero Aroca, de una cuestión más técnica que política: "Tendía a una mayor efectividad de la justicia, a evitar los conflictos entre 'jurisdicciones' y la impunidad de los delitos, a la unidad del sistema en la administración de justicia. La unificación de fueros es un instrumento de la centralización propia de la ideología liberal, aunque en último extremo aspira a la igualdad entre los ciudadanos" (484). Ello a pesar de la trascendencia que el Discurso Preliminar da al proceso penal, cuya reforma califica de muy urgente: "Toda dilación en su mejora -añadía- es de la más grave trascedencia, todo error puede acarrear daños irreparables" (485).

La verdadera garantía penal no está en que el juez vele por los derechos del inculpado, sino en que éste pueda hacerlos valer por sí mismo frente a cualquiera, incluso frente al mismo juez que, no lo olvidemos, no es más que una parte, y parte acusadora además, en el proceso penal inquisitivo (486). Ante la pervivencia de un proceso penal medieval, en 1837, pese a la redacción de un nuevo texto constitucional, se conservó la vigencia parcial de la Constitución de 1812 en sus apartados relativos a la potestad jurisdiccional y al proceso penal. Pero por lo demás, se mantuvo el proceso inquistivo, donde estaban ausentes las más elementales posibilidades de defensa: El procedimiento penal inquisitivo -escribe Tomás y Valiente- ha sido siempre un arma autoritaria e intimidativa, tanto cuando quien la ha esgrimido ha sido el 
Estado como cuando fue ampliamente utilizada por la Iglesia. Todas las cortes europeas bajomedievales comienzan a emplear el 'ius puniendi' como un arma política: por ello es lógico que en todas ellas arraigara el procedimiento penal inquisitivo dentro de las respectivas jurisdiccionales reales ordinarias" (487).

Las verdaderas garantías y el verdadero derecho de defensa se articularon fuera del ámbito judicial y fuera del ámbito privado, en instrumentos públicos, tanto dentro como incluso fuera del ordenamiento jurídico, como el derecho de resistencia y sus concretas configuraciones. Fueron garantías de naturaleza pública y no privada; su salvaguardia estaba en el poder legislativo y no en el judicial; por poner otro ejemplo más, el art.III del Capítulo III del Reglamento de la Regencia de enero de 1811, al autorizar la detención gubernativa por un plazo máximo de 48 horas, añade que toda infracción será reputada como atentado contra al libertad de los ciudadanos, "y cualquiera en este caso estará autorizado para recurrir en queja ante las Cortes". Juan Miguel de los Ríos diferenció abiertamente ambos tipos de de garantías. Las privadas "tienen por objeto asegurar a los asociados los derechos absolutos que ya hemos dicho haber recibido de la naturaleza y que pueden reducirse: 1) a la seguridad de personas y propiedades; 2) a la libertad de industria, de opiniones y conciencia" (488). Y respecto de las otras afirmaba que "la primera y más sólida garantía pública, que en sí las reune todas, es la buena constitución de los poderes políticos que sea más conforme a la índole, carácter y circunstancias de cada país y época" (489). En parecidos términos se expresó luego Jellinek: "Las garantías del Derecho Público radican, ante todo, en la organización del Estado y de las asociaciones jurídicas de carácter público".

La ley y, por tanto, la cámara legislativa, debían asegurar los derechos fundamentales. La invocación de las asambleas legislativas y su frecuente convocatoria es muy socorrida en las declaraciones de derechos como baluarte y salvaguardia última de esos mismos derechos. Es significativo el último número del "bill of rights" al manifestar: "Y que para remediar todos estos agravios, y para conseguir la rectificación, aprobación y mantenimiento de las leyes, el Parlamento debe reunirse con frecuencia". Así también el art.22 de la Declaración de Derechos de Massachusetts decía: "El cuerpo legislativo debe reunirse frecuentemente para reparar los agravios, corregir, reforzar y ratificar las leyes, y para hacer nuevas leyes, según lo requiera el bien común". Lo mismo puede leerse en el Discurso Preliminar, donde se atribuye la supuesta crisis de las tradicionales libertades políticas y civiles al "decaimiento de la celebración de Cortes"; aquellos primeros constituyentes consideraban "la frecuente reunión de Cortes como un verdadero obstáculo a la arbitrariedad de su gobierno y a la usurpación que se intentaba hacer de las libertades de los españoles" (490).

Los límites de los derechos subjetivos alcanzaban hasta donde comenzaban los de un tercero (491), donde comenzaba la libertad política (492), límites que sólo la ley podía definir: "La ley -decía el art.4 de la Declaración de 1789consiste en poder hacer todo aquello que no daña a otro; así el ejercicio de los derechos naturales de cada hombre no tiene otros límites que los que aseguran a los otros miembros de la sociedad el disfrute de esos mismos derechos. Esos límites no puede ser determinados más que por ley". Sieyes clasificó las leyes en dos grupos: leyes directrices y leyes protectoras (493), categoría esta última 
de la que también habló Flórez Estrada (494) y que derivaba del hecho de que las leyes no concedían derechos, sino que los protegían (495). Todavía Duguit sostenía que "la ley puede ser mala, injusta; pero estando formulada por vía general y abstracta, ese peligro se encuentra reducido al mínimo. Así, de nuevo, el carácter protector de la ley, su misma razón de ser, se encuentra en su generalidad" (496).

El problema radica en que la garantía de un derecho no puede descansar en otro derecho; la ley, por su carácter genérico, no puede constituir una garantía satisfactoria; pero este ha sido el proceso seguido por el constitucionalismo, de manera que en garantía de unos derechos aparecieron otros, esencialmente garantizadores, de naturaleza instrumental, especialmente el de petición y el de reunión. El derecho de petición es una derivación de la petición de derechos, característica de la revolución inglesa (497), donde la función de la cámara baja era predominantemente tributaria, mientras que el Derecho era de origen consuetudianario. El giro consistió en establecer el principio "las quejas antes que los subsidios" (498).

Con relación al derecho de reunión, es transparente la redacción del art.19 de la Declaración de Massachusetts: "El pueblo tiene derecho a reunirse, de una manera ordenada y pacífica para tratar acerca del bien común, dar instrucciones a sus representantes y solicitar del cuerpo legislativo, por medio de apelaciones, peticiones o reconvenciones, que repare los daños que hayan podido cometer o los males que sufren". La misma vinculación entre el derecho de reunión y el remedio de agravios se da en la primera enmienda de la Constitución estadounidense, hasta que a mediados del siglo XIX Tocqueville pudo concluir ya que "en nuestro tiempo la libertad de asociación se ha convertido en una garantía necesaria contra la tiranía de la mayoría” (499).

La Milicia Nacional fue una de esas decisivas garantías de naturaleza pública, es decir, la burguesía en armas, su derecho de autodefensa colectiva frente a los riesgos derivados de un ejército permanente dependiente del ejecutivo porque, como observó Sieyes con realismo, "la garantía de la libertad pública no puede estar sino allí donde esté la fuerza real" (500). El art.13 de la Declaración de Virginia decía que "una milicia bien regulada, reclutada entre el pueblo, entrenada en el manejo de las armas, es la defensa adecuada, natural y segura de un Estado libre; los ejércitos permanentes en tiempo de paz deben ser evitados como peligrosos para la libertad; $y$ en todo caso las fuerzas armadas estarán bajo estricta subordinación y gobierno del poder civil". Y en parecidos términos se expresaba la Declaración de Massachusetts: "El pueblo tiene derecho a tener y conservar armas para su defensa. Y como en tiempo de paz los ejércitos son peligrosos para la libertad, no deberán mantenerse sin el consentimiento del cuerpo legislativo; y el poder militar estará siempre subordinado a la autoridad civil y gobernado por ella". En Francia lo mismo decía el art.12 de la Declaración de 1789: "La garantía de los derechos del hombre y del ciudadano necesita una fuerza pública; esta fuerza está pues instituída en beneficio de todos y no para provecho particular de aquellos a quienes se confía".

Finalmente hay algo que, siguiendo a Rousseau podría calificarser de garantía negativa, que es la ley penal. Así, por ejemplo, no estaba asegurada la libertad 
de imprenta, pero se incriminaban tanto los impedimentos y obstáculos previos (la censura previa del Antiguo Régimen) como las injurias y calumnias. El Código Penal era la constitución en negativo; sólo se criminalizaba el abuso del derecho, de modo que, indirectamente, el ejercicio normal quedaba así tutelado. Pero esta construcción jurídica, tan peculiar por otra parte de liberalismo del siglo XIX, es al tiempo indicativo de la prioridad de la víctima sobre el inculpado. No pocas leyes reguladoras de los derechos fundamentales del siglo XIX son también -y a veces principalmente- leyes penales especiales.

\subsection{Breve excurso: la libertad de imprenta como prototipo}

Es quizá el mejor ejemplo que puede ilustrar acerca de la naturaleza de los derechos y libertades y su protección, porque como ha escrito Lucas Verdú, "los derechos sobre los cuales gravitaba la nueva fórmula política fueron la libertad de expresión del pensamiento y de opinión y el derecho de propiedad" (501). Era un "derecho" típicamente clasista y burgués, por lo que todas las declaraciones se hacen eco de él, en tanto no solamente no reconocen, sino que impiden, el derecho de reunión, que era la única posibilidad de participación política para una población masivamente analfabeta (502). La represión de las reuniones (equiparadas a las asonadas y motines) contrasta fuertemente con el mimo de la libertad de imprenta, que era eso precisamente: no un "derecho", sino una libertad de difusión del pensamiento sin trabas administrativas previas. Argüelles afirmaba en 1820 que no eran necesarias asociaciones porque ya estaba vigente la Constitución: "Suponer ahora que las Sociedades Patrióticas son necesarias equivale a afirmar que la Constitución es insuficiente para defender la libertad" (503). Parecida argucia utilizó Gareli: no son necesarias las sociedades porque para asegurar la Constitución -decíabastan "las galerías para asistir a las sesiones de Cortes, la libertad de imprenta y la de petición o representación para que se cumpla la Constitución" (504).

La libertad de imprenta era imprescindible para romper uno de los baluartes más importantes del absolutismo, sobre todo en el ámbito ideológico: la Iglesia (505). La burguesía contraponía la ignorancia y el analfabetismo de la población, sobre los que se sustentaba el monopolio ideológico de la Iglesia, a la ilustrración y el racionalismo. La Iglesia estaba estrechamente vinculada al Antiguo Régimen (506): era la vía de legitimación de la obediencia incondicional al poder de los monarcas. La revolución francesa, que innovó tantas cosas, también cambió en este punto la situación existente. Tocqueville ya observó cómo en épocas pasadas también existieron revoluciones, pero ninguna intentó penetrar en la sociedad "mediante la predicación y la propaganda" como la francesa de 1789, hasta el punto de que ella misma se convirtió "en una especie de religión nueva" (507). La libertad de imprenta era el libre mercado del mundo de las ideas, tan necesario como el de mercancías para la penetración de la nueva sociedad, para imponer la uniformidad espiritual y cultural, correlativa a la construcción de la nación y del mercado interior sobre los patrones de la burguesía nacional.

En manos de la burguesía era, además del parlamento, un instrumento más de presión contra el rey y su gobierno, que no siempre se limitaban a cumplir con la ley fielmente (508). La cámara legislativa era el medio de control oficial de la 
Administración; la prensa, el medio extra-oficial o extra-legal y, además, un medio para presionar a unos diputados excesivamente desvinculados de la sociedad por la prohibición del mandato imperativo: "Si el ejecutivo debía ser moderado por el legislativo -afirmaba Muñoz Torrero- éste no podía tener otro freno que el de la pública censura". En términos similares, afirmaba Constant que "todas las barreras civiles, políticas, judiciales, devienen ilusorias sin la libertad de prensa" (509).

La regulación concreta de la libertad de imprenta es el arquetipo de la concepción liberal de los derechos y garantías, así como del papel de los jueces dentro de este régimen legal: "En nuestros días -recurrimos nuevamente a Tocqueville- un ciudadano a quien se oprime no tiene, pues, más que un medio para defenderse; $y$ es dirigirse a la nación entera $y$, si se mantiene sorda, al género humano; no tiene más que un medio para hacerlo, y es la prensa. Así, pues, la libertad de prensa es inifinitamente más preciosa en las naciones democráticas que en todas las demás; ella sola cura la mayor parte de los males que la igualdad puede producir" (510). El ejemplo es tanto más válido cuanto que la libertad de imprenta desborda ampliamente el ámbito de lo privado, y se presenta como un "derecho" público y político (así lo califica el apartado 24 del art.131 de la Constitución de Cádiz), casi por antonomasia. Por ello mismo, es también un buen índice para comprobar la magnitud de los cambios que efectua la burguesía frente a la situación del Antiguo Régimen, y de aquellos sectores sociales que resultan protegidos o reprimidos por la normativa. Pues bien, puede principiarse afirmando del caso español que el Decreto de 10 de noviembre de 1810 sobre libertad de imprenta, defraudó a Blanco White (511), por poner un caso célebre, seguramente porque "concedía una libertad muy relativa", según sostiene Fiestas Loza (512). Y del siguiente de 1820 afirma Gil Novales que era un "modelo de tacañería espiritual de estas Cortes" (513). Obstaculizó precisamente a aquellas fuerzas que trataban de impulsar la revolución y promovió la agitación contrarrevolucionaria, resultando los "serviles" claros beneficiarios de la misma, hasta el extremo de que consiguieron controlar los órganos encargados de censurar las publicaciones(514), pues la libertad de imprenta, en general, no se caracteriza por la ausencia de censura, sino porque en lugar de ser previa, como en el Antiguo Régimen, es posterior (515). El Derecho Penal liberal es represivo y no preventivo. La libertad de imprenta significa, por tanto, el traslado de la censura al momento posterior a la publicación (516).

El papel de los jueces, en consecuencia, no era garantizador sino represivo; su intervención era siempre posterior a la publicación y para imponer sanciones. Lo que la primera legislación sobre esta materia trataba de garantizar era la eficacia del castigo; así, por ejemplo, debía figurar el impresor, que respondía en tales casos lo mismo que si fuera su autor.

Las causas que daban lugar a la censura y a su correspondiente sanción, eran muy amplias e iban desde la difamación, hasta la calumnia, e incluso los impresos "subversivos de las leyes fundamentales" (517). Por su puesto, en España la libertad de imprenta no era aplicable en materia religiosa, cuya regulación legal seguía siendo similar a la del Antiguo Régimen y competencia, además, de la Iglesia. $Y$ no podemos perder de vista que la noción del alcance de lo religioso estaba mucho más extendido que ahora, alcanzado a ámbitos 
que hoy reputaríamos profanos y estrictamente morales, culturales, políticos o sociales.

Importa, además, subrayar que la censura no estaba sometida a los tribunales ordinarios, sino que toda la materia fue objeto tradicionalmente de una legislación especial, penal y procesalmente hablando. El Decreto de 1810 creó las Juntas de Censura, presididas por la Junta Suprema, dependientes de las Cortes -una vez más- y al margen, en consecuencia, del sistema judicial. El art.39 de la Constitución de Bayona atribuía al Senado la misión de velar por "la conservación de la libertad individual y de la libertad de imprenta". El art.131.24 de la Constitución de Cádiz enumeraba entre las competencias de las Cortes, la de proteger "la libertad política de la imprenta". Tras el trienio, fue el jurado, que apareció así por primera vez en España, el instrumento judicial competente en materia de imprenta, pero el régimen jurídico continuó siendo totalmente especial.

En definitiva, la libertad de imprenta quedaba fuera del radio de acción jurisdiccional. Es más, afirma Martínez Sospedra que ni siquiera era un derecho, sino que lo califica como una mera facultad, como "un instrumento público dirigido a fines de pública utilidad y como un instrumento de defensa del sistema liberal que se pretende edificar" (518). Emilio La Parra ha criticado expresamente esta afirmación (519), si bien luego este mismo autor concluye reputándolo "como una inmediata consecuencia del principio de soberanía nacional” (520).

\section{Evolución posterior de la separación de poderes}

Los proyectos de los primeros constituyentes franceses -basados en elecciones permanentes (521)- eran viables únicamente en situaciones de calma política, y no en las exacerbadas condiciones de lucha de clases vividas por la revolución francesa. No solamente fracasó un determinado tipo de constituciones, sino todo el entramado socio-político ideado por aquellos primeros constitucionalistas. El punto central de la re-estrucuración fue el asalto de la burguesía al poder ejecutivo, que comienza cuando tras el fracaso de la fuga de Luis XVI a Varennes (junio de 1791), comienza a nombrar consejeros a los propios constituyentes: Barnave, Duport, los hermanos Lameth y otros destacados representantes de la burguesía, a los que inmediatamente relevaron los girondinos (522). El proyecto constitucional se había ideado sobre la base de un acuerdo entre la burguesía y la aristocracia para ejercer en común la potestad legislativa. Al oponerse el rey y la nobleza terrateniente a este reparto equilibrado del poder, al desencadenar la guerra civil, la burguesía tuvo que disponer también del ejecutivo, de todos los poderes. El Comité de Salud Pública y el terror (523) no fueron más que manifestaciones de esa situación de concentración de poderes y de guerra civil abierta entre las dos clases en liza. Son conocidas las palabras de Robespierre al respecto: "El objetivo del gobierno constitucional es el de conservar la República; el del gobierno revolucionario es el de fundarla" (524). La burguesía no tenía que controlar ni legalizar el ejercicio del poder ejecutivo por el rey, sino derrotar a la reacción en el campo de batalla. Tras el terror, Napoleón y las Cartas, los límites jurídico-constitucionales habían perdido todo el sentido. El ejecutivo, la Administración, se desarrollará inconteniblemente y se centralizará en las 
manos de una sola clase: la burguesía. "La autonomía del ejecutivo monárquico -escribe Kühnl- tenía que ser aceptada provisionalmente como mal inevitable en tanto no se modificara decisivamente el equilibrio de clases entre la burguesía y los estratos feudales en la sociedad. Sólo la república parlamentaria, en la que la representación popular determina incluso la composición humana del ejecutivo, corresponde plenamente a la idea liberal" (525).

La crudeza del enfrentamiento entre la burguesía y la aristocracia (guerra exterior, carestía, terror, etc.) exigió una configuración muy distinta de toda la organización del Estado. Ya no se trataba de la separación de poderes entre esas dos clases, pero todo el sistema originario se vio profundamente alterado. Incluso el reparto de competencias entre el ejecutivo y el judicial -que era de una importancia verdaderamente insignificante en relación con el deslinde entre el ejecutivo y e legislativo- se vio también sustancialmente modificado. En efecto, aunque desde el punto de vista teórico y jurídico la separación entre el ejecutivo y el judicial es el aspecto más discutible, porque ambos poderes ejecutivo y judicial- cumplen la misma función, aplicar las leyes, la cuestión no adquiere tanta importancia como el reparto de competencias entre el legislativo y el ejecutivo. No parece, en efecto, muy difícil separar al legislativo de los otros dos poderes, mientras que se ha prestado a muchas más discusiones la distinción entre la jurisdicción y la ejecución. Esta confusión, cómoda e interesada, así como la identificación entre el poder por antonomasia con el ejecutivo a partir del Imperio napoleónico y de la difusión del doctrinarismo, facilitará el cambio de significado de la separación de poderes en el pensamiento jurídico-constitucional. El doctrinarismo -sustancialmente monárquico- impondrá la idea de un "cuarto poder" que, en realidad, no era otra cosa que el rey y, tras de él, el ejecutivo y toda la Administración postnapoleónica. De ese modo, el legislativo dejó de ser reputado la "summma potestas" e incluso la expresión "gobierno" que hasta entonces era sinónimo de Estado, de los tres poderes, se identificará con el poder ejecutivo. Este acabó situándose por encima del legislativo, lo que modificará la concepción originaria de la separación de poderes, quedando el legislativo en una posición claramente subordinada (526). La revolución había pasado y se trataba de justificar nuevas necesidades políticas con viejos ropajes. Sucintamente clasificaremos esas nuevas realidad en los siguientes aspectos:

- el régimen parlamentario, dominado por la iniciativa legislativa del gobierno y el derecho de convocatoria y disolución de la Asamblea, es decir, un reforzamiento del ejecutivo frente al legislativo

- el régimen administrativo, o lo que es lo mismo, unas relaciones entre el ejecutivo y el judicial caracterizadas por la preeminencia del primero y la marginación del segundo.

Interesa remarcar este segundo aspecto porque es el que más ha contribuído a desdibujar el sentido originario de la separación de poderes. En aquel universo conceptual, establecida la superioridad del legislativo, cualquier sistema de relaciones entre los otros dos poderes era admisible y compatible con el principo general: su deslinde e independencia totales, la prioridad del judicial o la del ejecutivo. En Europa continental se impondrá este último, por la misma 
dinámica que le lleva a equipararse incluso con la Asamblea. Se impone por el propio proceso de gestación del Derecho Administrativo y, especialmente, de lo contencioso-administrativo. La Administración terminaría por desligarse completamente de cualquier posibilidad de control por parte de los tribunales ordinarios.

No fue sólo el sistema judicial lo que se hundió, sino también todo el complejo de municipalidades ideado por los constituyentes. Se impondrá el centralismo (527) y se impondrá una Administración que nada tenía que ver con las raquíticas atribuciones que los primeros pensadores liberales habían perfilado (528).

No es casualidad que suceda en Francia, donde la oposición de la nobleza al nuevo régimen fue total, y el centralismo estaba mucho más desarrollado que en Inglaterra. Los revolucionarios franceses tuvieron que recurrir a él para superar las tremendas dificultades que encontraron a su paso (529). La revolución desarrolló la técnica comisarial hasta límites insospechados: gobierno revolucionario, comités revolucionarios, tribunales revolucionarios, ejército revolucionario, etc. Las comisiones extraordinarias del Antiguo Régimen alcanzaron su apogeo precisamente en los momentos más intensos de la revolución burguesa. En todo el periodo revolucionario "el Derecho francés recorre en diez años un trayecto histórico de siglos” (530).

Las comisiones y la centralización se unieron al terror para romper por primera vez el mito del Estado neutral, con manifestaciones estridentes en lo religioso (diosificación de la razón y réplica deísta de los montañistas), en lo económico (asignado, salario máximo, "capitalismo de guerra") y en lo político (privación de derechos a los contrarrevolucionarios, beligerancia política de las instituciones, identificación entre el Estado y el partido). Es ahí definitivamente donde la supremacía del Estado sobre la sociedad se impone definitivamente: cualquier medida gubernativa, en pleno enfrentamiento interno e internacional era impensable sin un acompañamiento coactivo demoledor. El terror elevó el "imperium" de los poderes publicos, a la categoría de principio fundamental del nuevo Estado burgués en todos los órdenes; luego se suavizaron las formas, pero aquel bautismo de furia desatada dejó a cada cual, Estado y sociedad, en el sitio que definitivamente debía corresponderles.

Por supuesto, una quiebra tan escandalosa del Estado "neutral" suponía reputar a la Administración como un sujeto activo susceptible de engendrar una litigiosidad mucho mayor que cualquier otra persona física o jurídica, es decir, planteaba la cuestión de quién, de qué poder, resolvería esos pleitos. Asentado el principio de beligerancia de los poderes públicos y dispuesta la burguesía a reforzar la autoridad del Estado como mecanismo de solución de todos los problemas, decidida al empleo sistemático de la fuerza y la violencia, la conclusión era lógica: la Administración no descendería de su peldaño para pleitear con los ciudadanos en plano de igualdad y ante tribunales comunes. Lo contencioso-administrativo dió sus primeros balbuceos antes del terror, pero es consecuencia también de éste. La quiebra de la neutralidad dará vida propia al Estado, que se constituirá en una "persona jurídica" con sus propios medios y sus propios fines: se desarrolla la teoría de los órganos del Estado y del Estado como órgano (531). El organicismo de finales del pasado siglo desarrolló una 
nueva concepción social y política: de la separación entre el Estado y la sociedad pasó a su divorcio y mutuo enfrentamiento.

Esta evolución era consecuencia del creciente intervencionismo estatal, que conducirá a choques inevitables de la Administración con los de los particulares: la burguesía tuvo necesidad de arbitrar un remedio procesal frente a los excesos y abusos del Estado que cristalizará en lo contenciosoadministrativo.

Napoleón institucionalizó las experiencias jacobinas, que habían sido sólo provisionales e impuestas por las circunstancias. El modelo napoleónico reforzará hasta extremos inconcebibles hasta entonces el potencial de una Administración jerárquica y centralizada, simétrica a la Administración militar, y basada en el principio de autosuficiencia: la Administración es un universo, una totalidad que reproduce en su seno todos los componentes del mundo exterior. Del legislativo usurpa facultades importantes, como la de redactar reglamentos (art.44 de la Constitucion del año VIII), constituye tribunales administrativos al margen de los ordinarios y, al mismo tiempo, elude la fiscalización judicial (art.75 de la misma Constitución). Impide cualquier posibilidad de supervisión externa, crea organos parajudiciales para su autocontrol, y además se proyecta con energía hacia la sociedad (y hacia los demás países europeos), para "fomentar" el capitalismo, abandonando la actitud pasiva y contemplativa con que hasta entonces se la había concebido. Se invierte todo el cuidadoso equilibrio de poderes y clases propuesto por el primer constitucionalismo. En las relaciones entre la Administración y los tribunales se experimenta una preponderancia casi absoluta de la primera, que acapara funciones claramente jurisdiccionales y, al tiempo, dispone de mecanismos para eludir la fiscalización jurisdiccional (532).

Con la Administración en sus manos, la burguesía consolida sus posiciones políticas y económicas (perpetúa las adquisiciones de bienes desamortizados, por ejemplo) y emprende una actividad de expansión del capitalismo dentro y fuera de las fronteras: no solo edifica un nuevo Estado, sino una sociedad a su imagen y semejanza (533). "La revolución francesa -observó Tocqueville- no tuvo solamente por objeto cambiar un gobierno antiguo, sino abolir la forma antigua de la sociedad" (534). La Administración, escribe Santamaría Pastor, era el "instrumento necesario para llevar a cabo la transformacion social que la Revolución postulaba: una transformación que suponía la anulación de las clases privilegiadas del Antiguo Regimen y la instalación de la burguesía en el poder sólo podía realizarse merced a una Administración poderosa $y$ fuertemente centralizada. Sin duda, en la dinámica histórica del Derecho administrativo, la organización precede a la garantía, pues sólo cuando la burguesía hubo construído el instrumento que le daría el poder político y económico, sintió la necesidad de controlar jurídicamente a ese instrumento, cuyo excesivo poder podía en algunas ocasiones resultarle perjudicial" (535). Todo el cuidadoso equilibrio social ofertado por los primeros constituyentes se viene abajo. La Administración se sobrepone al legislativo (v.gr. facultad reglamentaria), a la Administración local (mediante el centralismo) y a los jueces (mediante lo contencioso-administrativo). Este desarrollo es progresivo e imparable en la Europa continental. La creación de lo contenciosoadministrativo fue solo un primer paso; en realidad la Administración acabó 
imponiéndose totalmente a la jurisdicción ordinaria, en el orden civil con instituciones tales como la prohibición de plantearle interdictos, en el penal en varios aspectos claves, tales como la facultad sancionadora (536), la autorización administrativa previa para procesar a los funcionarios (537), etc.

Pero el núcleo esencial de esa reestructuración política fue la creación del "poder moderador": la existencia de un poder real distinto del poder ejecutivo, dirá Constant, es "la clave de toda organización política" (538). La formación de este nuevo ente constitucional, desconocido para el primer pensamiento constitucional (539), perdurará hasta finales de siglo, de manera que Jellinek, por ejemplo, situará en el centro de su teoría un "organo supremo del Estado" (540) que, no sólo no es el legislativo, sino que está por encima del legislativo.

\section{Notas}

(1) Queremos exceptuar expresamente de esta tendencia generalizada a Charles Eisenmann y Michel Troper, que sobresalen entre quienes se han esforzado por situar la separación de poderes en sus coordenadas históricas, políticas e ideológicas.

(2) "Ha llegado el momento en que nos encontramos ante la teoría nuda, ante el arquetipo indiferente a la experiencia, desasido de los supuestos históricos que tuvo a la vista quien formuló la doctrina. Se ha creado el mito político. Del mito que inspira reverencia se pasa al tópico que populariza el mito y le hace rodar entre las multitudes. Mito y tópico, la división de poderes marcha por sí sola, se adapta a las realidades políticas más variadas y cuando no puede adaptarse, las fuerza" (C.Ruiz del Castillo, con Pérez Serrano y Gascón y Marín: La separación de poderes, Academia de Ciencias Morales y Políticas, 1950, pgs.31-32).

(3) Tratado de Derecho Administrativo, Madrid, 1898, tomo I, pg.215.

(4) Teoría general del Estado, Albatros, Buenos Aires, 1981, pg.377. Lo mismo sostenían en Francia, antes incluso que Jellinek, autores como Artur o Michoud.

(5) "Lo que corrientemente, aunque erróneamente, se suele designar como la separación de poderes estatales, es en realidad la distribución de determinadas funciones estatales a diferentes órganos del Estado" (Teoría de la constitución, Ariel, Barcelona, 2aㅡ. Ed., 1979, pg.55). En parecidos términos, Sánchez Agesta: "Poder ejecutivo y división de poderes", Revista Española de Derecho Constitucional, 1981, núm.3, pg.14.

(6) “El príncipe moderno”, en Política y sociedad, Península, Barcelona, 1977, pg.176.

(7) Juan Vallet de Goytisolo: Montesquieu: leyes, gobiernos y poderes, Civitas, Madrid, 1986, pg.358. En relación precisamente con la separación de poderes, escribió Madison: "Además de la oscuridad que es resultado de la complejidad de los objetos y de la imperfección de las facultades humanas, el medio a través del cual los hombres transmiten sus ideas agrega una nueva dificultad. Las palabras sirven para expresar ideas; por lo tanto, la lucidez exige no sólo que las ideas se conciban con claridad, sino que se expresen con palabras distintas y exclusivamente apropiadas a ellas. Pero ningún idioma es lo bastante rico para proporcionar palabras y locuciones para cada idea compleja, ni tan correcto que no incluya muchas equívocamente denotativas de distintos conceptos. De ahí que, por muy exactamente que se diferencien en sí mismos los objetos y por mucha que sea la precisión con que se piense en esa diferencia, su definición puede resultar inexacta por la inexactitud de los términos con que se exprese. $Y$ esta inevitable inexactitud puede ser mayor o menor según la complejidad y la novedad de los objetos definidos" (El federalista, Fondo de Cultura Ecónómica, México, 1987, pg.150). 
(8) Loewenstein ha constatado la existencia de unos detentadores invisibles del poder: "Mientras que los detentadores del poder oficiales, legítimos y visibles pueden ser identificados sin dificultad en la constitución -sostenía- a los detentadores del poder invisibles, no oficiales y no legítimos, exige en cada caso un análisis sociológico de la realidad del proceso del poder" (ob.cit., pg.37). Según este autor las influencias extraconstitucionales en el proceso del poder es "el fenómeno político más significativo en la moderna sociedad de masas" (pg.38). Jürgen Habermas ha encontrado la causa de este fenómeno en la desaparición de los límites entre la sociedad y el Estado que se verifica en el capitalismo monopolista contemporáneo, de modo que el Estado se ve sometido a las presiones de los grandes consorcios económicos, sobre los cuales no hay forma alguna de control político: vid. "Concepto de participación política", en Capital monopolista y sociedad autoritaria, Fontanella, Barcelona, 1973, pgs.50-51; sobre el complejo público-privado en la actualidad, M.García Pelayo: Las transformaciones del Estado contemporáneo, Alianza, Madrid, 2a Ed., 1985, pgs.202 y stes. Esta situación parece claramente atentatoria al monopolio del poder por el Estado: vid. Alejandro Nieto: Estudios históricos sobre Administración y Derecho Administrativo, Instituto Nacional de Administración Pública, Madrid, 1986, pg.72.

(9) P.Lucas Verdú: Curso de Derecho Político, Tecnos, Madrid, 1974, vol. 2, pgs.142 y stes.

(10) En Inglaterra la fuerza de los jueces deriva, por una parte, de su histórica identificación con la Cámara de los Lores, una porción del poder legislativo (Lord Wilberforce: "La Chambre des Lords", Revue Internationale de Droit Comparé, 1978, pg.85); en segundo lugar de que la doctrina de la soberanía allí se identificó en parte, por ejemplo Edward Coke, con la soberanía del "common law" cuya interpretación estaba encomendada a los jueces, convertidos así en el poder supremo del Estado (John Neville Figgis: El derecho divino de los reyes, Fondo de Cultura Económica, México, 1982, pg.179, y M.García Pelayo: Derecho Constitucional Comparado, Alianza, Madrid, 1984, pgs.262-263); y en tercer lugar, por la alianza de clases que se verifica en la revolución, donde la nobleza rural que ocupaba los cargos judiciales locales, se unió a la burguesía contra la realeza, viendo reforzadas sus posiciones (Ernest Glasson: Histoire du Droit et des institutions politiques, civiles et judiciaires de l'Angleterre, Paris, 1883, tomo V, pgs.78 y stes.). Los jueces estadounidenses, como observó Tocqueville, eran una de las primeras potencias políticas (La democracia en América, I-1-6, citaremos del resumen de la Ed.Guadarrama, Madrid, 1969, pg.95) que allí derivaba del carácter de "ley suprema" que tenía la Constitución y del control de la constitucionalidad de las leyes por el Tribunal Supremo. Pero, como apuntó Hamilton esto no significaba superioridad del poder judicial frente al legislativo, sino sólo que el poder del pueblo -reflejado en la Constitución- es superior a ambos (El federalista, pg.332). Aún así, nadie llegó a sostener la superioridad del judicial sobre el legislativo después de la revolución. Laski, por poner un ejemplo, defendió la superioridad del poder judicial sobre el ejecutivo; pero a su vez, el judicial lo concebía supeditado al parlamento (El Estado. Sus instituciones políticas y económicas, Bosch, Barcelona, 1932, tomo II, pg.7).

(11) El proyecto de Constitución hablaba de poder y no de potestad (Actas de la Comisión de Constitución, Estudio Preliminar de María Cristina Diz-Lois, Instituto de Estudios Políticos, Madrid, 1976, pg.86). Sabemos que se discutió sobre el epígrafe el 23 de agosto (pg.197), hasta que se optó finalmente el día 29 de ese mismo mes por el término "potestad" (pg.199), sin que el laconismo de las actas nos de una explicación, por mínima que sea, de las razones que hubo para ello, ni del debate que seguramente se estableció al respecto. Gascón y Marín, sin embargo, identificó poder y potestad, considerándolos como sinónimos (con Pérez Serrano y Ruiz del Castillo, ob.cit., pg.51) y E.Pedraz Penalva tiene en cuenta la distinción, pero su explicación al respecto no nos parece satisfactoria (Formación de la jurisdicción, Texto mecanografiado, Universidad de Salamanca, 1972, pgs.381 a 391).

(12) E.García de Enterría y T.R.Fernández: Curso de Derecho Administrativo, Civitas, Madrid, $4^{\text {a }}$ Ed., 1983 , tomo I, pgs. 419 y stes.

(13) Max Weber: Economía y sociedad, Fondo de Cultura Económica, México, 2ª Ed., 1964, pg.1056.

(14) Traité de Droit Constitutionnelle, Paris, 3a Ed., 1927, tomo I, pg.710; Kelsen, Teoría pura del Derecho, Universidad Autónoma de México, México, 1988, pgs.49-50; Fréderic Maurice: "La 
loi mediation de la violence", Deviance et societé, 1980, vol.IV, núm.2, pgs.156-157; André Hauriou: Derecho Constitucional e instituciones políticas, Ariel, Barcelona, 1971, pg.143; en España la definición se incorporó al Derecho positivo en el preámbulo de la Ley 2/86 de cuerpos y fuerzas de seguridad del Estado; véase también la intervención del diputado Gabriel Cisneros ante el Congreso (Diario de Sesiones, 8 de noviembre de 1978, pg.5322), y J.Bustos Ramírez: Control social y sistema penal, PPU, Barcelona, 1987, pgs.475 y stes. Pero en Duguit la tesis adquiere una connotación especial: el monopolio de la coacción "por definición misma" corresponde al Estado.

(15) Cfr. V.Fairén Guillén: "Poder, potestad y función jurisdiccional en la actualidad", Estudios de Derecho Procesal, Civil, Penal y Constitucional, EDERSA, Madrid, 1983, pgs.11 y stes. Hans Hattenhauer: Los fundamentos histórico-ideológicos del Derecho alemán, EDERSA, Madrid, 1981, pg.25; Serra Domínguez ha propuesto la diferenciación entre poder y autoridad, en este mismo sentido, pero conceptuando la potestad como algo separado de la jurisdicción, posterior y relativo a la ejecución (Estudios de Derecho Procesal, Ariel, Barcelona, 1969, pgs.50 y 65). J.Ferrando Badía ha hablado del poder como una suma de "potestas" y "auctoritas" (Estudios de Ciencia Política, Tecnos, Madrid, 1976, pgs.410-413). Pasamos por alto la distinción entre "imperium", "auctoritas" y "potestas" que, según entendemos, carece de relieve a los efectos expositivos que aquí perseguimos; pero tenemos en cuenta su diferenciación, según ha expuesto D'Ors (v.gr. en su Derecho privado romano, Universidad de Navarra, Pamplona, 1981, pgs.54 y 55.

(16) Projet de constitution pour la Corse, Flammarion, Paris, 1990, pg.147.

(17) ¿Qué es una constitución?, Ariel, Barcelona, Barcelona, 1976, pgs.77 y stes.

(18) Teoría general, pgs.320 y stes.

(19) Sobre la relación poder-fuerza-Derecho, Juan Zaragüeta: "Derecho y fuerza", en Anales de la Real Academia de Ciencias Morales y Políticas, núm.45, Madrid, 1968, pgs. 133 a 147; Heinrich Henkel: Introducción a la Filosofía del Derecho, Taurus, Madrid, 1968, pgs. 135 y stes.; y N.Bobbio: Contribución a la teoría del Derecho, Fernando Torres Ed., Valencia, 1980, pgs.335 y stes. No solamente el poder tiene un componente claro de fuerza, de violencia, sino que el propio Derecho se ha identificado con esa "vis" física. Según D'Ors "en su concepción originaria 'ius' se dice propiamente del acto de fuerza que realiza formalmente una persona, $y$ que la sociedad mediante sus jueces reconoce como ajustado a las conveniencias... El más antiguo 'ius' consiste en un orden de poderes personales... Estos poderes se manifiestan en actos de fuerza (vis) pero formalmente ritualizados" (ob.cit., pgs.43 a 47). Al respecto es clásica la identificación de Spinoza entre Derecho y poder (v.gr. Tratado político, Alianza, Madrid, 1986, pg.93).

(20) Les constitutions de la nation française, Paris, 1819, tomo I, pgs.202-203.

(21) "El inmenso poder que se ha adjudicado a la autoridad Real -decía el Discurso Preliminar de 1812- necesita de un freno que constantemente le contenga dentro de sus límites; de cualquiera que éstos sean, reducidos a la ineficacia de una ley escrita, sólo opondrán siempre una débil barrera al que tiene a su mando el ejército, el manejo de la Tesorería y la provisión de empleos y gracias, sin que la autoridad de las Cortes tengan a su disposición medios tan terribles para traspasar los límites prescritos a sus facultades debilitados ya en gran medida por la sanción de la ley" (Colección de leyes fundamentales, Textos editados por R.Sáinz de Varanda, Acribia, Zaragoza, 1957, pg.43).

(22) "Teología política", en Estudios políticos, Doncel, Madrid, 1975, pg.47.

(23) En defensa de las Cortes, Ciencia Nueva, Madrid, 1967, pgs.46 y 47.

(24) Teoría general, pg.327.

(25) "Las leyes fundamentales suponen necesariamente ciertos conductos intermedios por donde fluya el poder" (Montesquieu: El espíritu de las leyes, II-4, citaremos de la Ed.Tecnos, Madrid, 1969, pg.61). Escribe Althusser que "el verdadero objeto de Montesquieu es precisamente la combinación, el enlace de esas tres potencias. Y que se trata ante todo de un 
problema político de relación de fuerzas, en vez de un problema jurídico que concierne a la definición de la legalidad y sus esferas" ( Montesquieu: la política y la historia, Ariel, Barcelona, $2^{\mathrm{a}}$ Ed., 1974, pgs.117 y stes.). En parecidos términos Carl Schmitt: La dictadura, Alianza, Madrid, 1985, pg.138; André Hauriou, ob.cit., pg.237; L. Sánchez Agesta: Principios de teoría política, Ed.Nacional, Madrid, 1976, pg.464; García de Enterría y T.R.Fernández, Curso, tomo I, pg.468; Pedraz Penalva, Formación, pgs.350 y stes. y "La jurisdicción en la teoría de la separación de poderes de Montesquieu", Revista de Derecho Procesal, 1976, núm.4, pg.928.

(26) Joseph R. Strayer: Sobre los orígenes medievales del Estado moderno, Ariel, Barcelona, 1986, pg.15; Joaquín Varela Suances-Carpegna: La teoría del Estado en los orígenes del constitucionalismo hispánico (Las Cortes de Cádiz), Centro de Estudios Constitucionales, Madrid, 1983, pgs.71 y stes.; García Pelayo, Derecho Constitucional Comparado, pgs.147-148.

(27) Vid. Ernst Forsthoff: Tratado de Derecho Administrativo, Instituto de Estudios Políticos, Madrid, 1958, pgs.51 y stes.

(28) En alusión a Inglaterra, vid García de Enterría y T.R.Fernández, Curso, tomo I, pg.463.

(29) Bartolomé Clavero ha identificado revolución burguesa con imposición del Derecho Civil liberal ("Política de un problema: la revolución burguesa", en Estudios sobre la revolución burguesa en España, Siglo XXI, Madrid, 1979, pg.42); los clásicos -sostiene- no prefiguran tanto la "libertad política" como la generalización de la "igualdad civil, de las relaciones de mercado" (ibid, pg.37).

(30) "Se llama tirano al soberano que no conoce más leyes que su capricho, que se apodera de los bienes de sus súbditos y que además los enrola para ir a apoderarse de los de sus vecinos. De esta clase de tiranos no hay en Europa" (Diccionario filosófico, Petronio, Barcelona, 1978, tomo II, pg.261). También Rousseau sostuvo que ninguna ley podía privar a un ciudadano de ninguna porción de su propiedad (Constitution pour la Corse, pg.145). En España, un comentarista que escribe durante el trienio liberal afirma que la prohibición de las confiscaciones por la Constitución es la "sentencia de muerte contra el monstruo fiscal que tantas y tan gruesas fortunas ha devorado en tiempos infelices de nuestro suelo, y que aún amenaza devorarlas en otros donde esta aflicción tan inmoral no ha sido todavía desechada" (Los principios de la Constitución española y los de la justicia universal aplicados a la legislación de señoríos, o sea, concordia entre los intereses y derechos del Estado y los de los antiguos vasallos y señores, por un jurisconsulto español, Madrid, 1821, pg.166). Cfr. Alejandro Nieto, Estudios, pgs.146 y stes.

(31) J.A.Alvarez-Caperochipi: Reforma protestante y Estado moderno, Civitas, Madrid, 1986, pgs.92-93 y 137. Esto no entra en contradicción con la importancia que Montesquieu precisamente concede a los cuerpos intermedios; primero porque se refiere a ellos en relación con los regímenes monárquicos; y segundo, porque cuando lo hace en términos generales, alude a las clases sociales; pasa entonces del lenguaje jurídico al político: "El poder intermediario subordinado más natural es el de la nobleza", dice (ob.cit.,Il-4, pg.61); y también: "En el Estado popular, el pueblo se divide en clases" (ibid, II-2, pg.57). A diferencia de Rousseau, no trata a los individuos como entes atomizados, sino agrupados en clases sociales: en esto radica la superioridad y el realismo de su análisis sobre el del ginebrino. Su dualismo sería "Estado-clases" mientras Rousseau contrapone "Estado-individuo". Para éste, el cuerpo intermedio entre el soberano y los súbditos no es ninguna clase, sino una institución, el gobierno (Del contrato social, III-1, Alianza, 1988, pg.62), aunque también se encuentran afirmaciones suyas en sentido opuesto (Constitution pour la Corse, pgs.124-125). La misma posición de Montesquieu es defendida por Hegel, partidario también de los estamentos y cuerpos intermedios: "El estado concreto -afirma Hegel- es la totalidad articulada en sus círculos particulares; el miembro del estado es un miembro de una de estas clases, y sólo en esta determinación objetiva puede ser tomado en consideración el estado" (Principios de la Filosofía del Derecho, Edhasa, Barcelona, 1988, pg.394).

(32) "Un poder de tipo feudal o patriarcal no conoce fronteras entre lo privado y lo público. Los derechos públicos del señor feudal sobre villanos eran al mismo tiempo sus derechos como propietario privado; recíprocamente sus derechos privados o sus pretensiones privadas pueden ser interpretados, si se quiere, como derechos políticos, es decir, públicos" (Evgeni Pasukanis: 
Teoría general del Derecho y marxismo, Labor, Barcelona, 1976, pg.116). Hattenhauer, ob.cit., pg.21; en realidad esta no es una característica singular del Estado liberal respecto de otras superestructuras políticas, sino del Estado en general, que surge de la disolución de los vínculos gentilicios: lo que éste hace es llevar hasta sus últimos extremos este deslinde, que llamó la atención de Locke (Ensayo sobre el gobierno civil, Aguilar, Madrid, 1986, pgs.40 y stes.) porque mientras la familia era un ente natural, inmutable, el Estado debía ser artificial, creación humana y modificable.

(33) Según el Discurso Preliminar, "Napoleón, para usurpar el Trono de España, intentó establecer, como principio incontrastable, que la Nación era una propiedad de la familia Real" (Colección de leyes fundamentales, pg.37). La noción absolutista de soberanía, según Forsthoff, era indiferenciable de la potestad real, doméstica y cortesana: "El comienzo de la Administración, en el moderno sentido de la palabra, hay que situarlo en el momento en que el poder soberano supera su materialización en la posesión patrimonial y en los derechos de soberanía singulares y se objetiviza en la ejecución de cometidos estatales de índole general" (ob.cit., pgs.36 y 37). Vid. Alejandro Nieto, Estudios, pgs.138 y stes. y Hattenhauer, ob.cit., pg.35.

(34) Labor desarrollada por los impulsores de la doctrina de la soberanía. Así Spinoza escribía al respecto: "Nuestra conclusión es, pues, que sólo en relación a la capacidad del vulgo y a su falta de comprensión se describe a Dios como legislador o príncipe y se le denomina justo o misericordioso, etc. Porque, en realidad, Dios obra únicamente por necesidad de su naturaleza y de su perfección, y así dirige todas las cosas. Sus decretos y voliciones son verdades eternas y siempre implican una necesidad" (Tratado teológico-político, Alianza, Madrid, 1986, pg.146). En este apartado destaca igualmente el pensamiento de Hobbes, donde la teología se transforma en una rama de la política ("En todo Estado cristiano el soberano civil es el pastor supremo", sostiene en su Leviatan, III-42) invirtiendo los términos tradicionales. Fue abordada también por Locke en su "Carta sobre la tolerancia" (citaremos de la Ed.Tecnos" >la Ed.Tecnos, Madrid, 1985), concepto éste de "tolerancia"que permite al Estado sobreponerse a cualquier ligadura eclesiástica. "El tiempo de las guerras religiosas había pasado, el de las guerras políticas aún no había venido", afirmará expresivamente Guizot (Historia de la revolución de Inglaterra, Sarpe, Madrid, 1985, pg.332). Vid. también Figgis, ob.cit., pg.167; Ernst Cassirer: La filosofía de la Ilustración, Fondo de Cultura Económica, México, $3^{\text {a }}$ Ed., 1984, pgs.182 y stes., y Henry Kamen: Nacimiento y desarrollo de la tolerancia en la Europa moderna, Alianza, Madrid, 1987.

(35) Cfr. Schmitt: "La época de la neutralidad", en Estudios políticos, ya citada; y Alejandro Nieto, Estudios, pg.157.

(36) Albert Soboul: Compendio de la historia de la revolución francesa, Tecnos, Madrid, 1989, pg.136; y Georges Léfebvre: La revolución francesa y el Imperio, Fondo de Cultura Económica, México, 1980, pg.63.

(37) De origen luterano, según ha expuesto Alvarez-Caperochipi, Reforma protestante, pgs.144-145.

(38) Del contrato social, III-1, citaremos de la traducción de Alianza Editorial, Madrid, 1988, pg.65.

(39) Escritos y discursos de la revolución, Centro de Estudios Constitucionales, Madrid, 1990, pg.104.

(40) Por "salud del Estado" dice Kant, no hay que entender "ni el bienestar de los ciudadanos ni su felicidad; porque ésta probablemente puede lograrse de forma mucho más cómoda y deseable (como también afirma Rousseau) en el estado de naturaleza o también bajo un gobierno despótico; sino que se entiende un estado de máxima concordancia entre la constitución y los principios jurídicos, estado al que la razón nos obliga a aspirar a través de un imperativo categórico" (La metafísica de las costumbres, Tecnos, Madrid, 1989, pg.149). Según Schmitt, el Estado moderno es fruto de una técnica política: la "aequitas" y la "iustitia" dominan en el Derecho privado; en el público la "salus publica", la "vis dominationes"; el Estado debería funcionar como una máquina perfecta con arreglo a las normas constitucionales que se le 
impongan (La dictadura, pgs. 44, 50 y 138). Vid. Alejandro Nieto: La burocracia. El pensamiento burocrático, Instituto de Estudios Administrativos, Madrid, 1976, pg.83.

(41) Hattenhauer, ob.cit., pg.32.

(42) Ensayo, pg.5.

(43) Esto da lugar a que el delito de rebelión se configue (art.274 del Código Penal de 1822) como un atentado a la obediencia que se debe a la autoridad legalmente constituída. Y que todas las Constituciones españolas (excepto la de 1869 y la actual) hayan sancionado con la pérdida de la nacionalidad española a quienes acepten empleo de un gobierno extranjero.

(44) Leviatan, I-15.

(45) Del contrato social, I-7 y I-6, pgs.27-28 y 26.

(46) Discours sur l'économie politique, en la edición de Flammarion ya citada, pg.58.

(47) Diz-Lois, ob.cit., pgs.78-79.

(48) La burocracia, pg.84.

(49) Como afirman, entre otros, R.Carre de Malberg: Contribution a la théorie générale de l'Etat, Paris, 1922, tomo II, pg.8; F.Tomás y Valiente: Manual de Historia del Derecho español, Tecnos, Madrid, 1979, pgs.422 y stes.; J.Solé-Tura y E.Aja: Constituciones y periodos constituyentes, Siglo XXI, Madrid, 13를 Ed., 1985, pg.18; y Pedraz Penalva, Formación,pg.378. Pero el propio Montesquieu sostuvo algo que está más próximo a Bodino, Hobbes o Spinoza que al sistema actual de legalidad: "En una Monarquía el que hace observar las leyes está por encima de ellas" (ob.cit., III-3, pg.63). Al entrar más adelante en el concepto de prerrogativa se observará con claridad hasta qué punto estas ideas están alejadas del "Estado de Derecho".

(50) Como afirman, por ejemplo, García Pelayo, “Las transformaciones...”, pg.52, y Sánchez Agesta, "Poder ejecutivo...", pg.16. La supuesta autovinculación del poder legislativo por medio de leyes no es, en expresión de Schmitt, más que "una frase vacía" (La dictadura, pg.141).

(51) Duport no dejó traslucir ninguna perplejidad ante la falta de encaje del Alto Tribunal creado por la Constitución de 1791 con nuestra versión actual de la separación de poderes, sino todo lo contrario: "No entra en el plan judicial propiamente dicho; es una parte, una pieza, por así decirlo, de la constitución general" (Choix de rapports, opinions et discours recueillis par Alexis Eymery, Paris, 1818, tomo III, pg.232). Y eso que para Lair "la creación del alto tribunal nacional no es, en realidad, más que un prefacio del tribunal revolucionario" (Des Hautes Cours politiques en France et a l'etranger et de la mise en accusation du President de la Republique et des ministres, Paris, 1889, pg.127). Respecto al mismo punto y en relación con la Constitución del Estado de Nueva York, escribió Hamilton: "Esta Constitución hace del senado, unido al presidente y a los jueces de la Suprema Corte, no sólo un tribunal para los delitos de funcionarios, sino el tribunal supremo del Estado para todas las causas, sean civiles o criminales. La proporción numérica del presidente y los jueces en relación con los senadores es tan insignificante que puede decirse sin yerro que la autoridad judicial de Nueva York reside en última instancia en su senado" (El federalista, pg.281). Sin embargo, hoy Wilberforce sostiene que la naturaleza judicial y legislativa al mismo tiempo de la Cámara de los Lores, constituye un atentado radical y único en las democracias occidentales, a la separación de poderes (ob.cit., pg.85).

(52) Gascón y Marín, con Pérez Serrano y Ruiz del Castillo, ob.cit., pgs.56 y 57; también Kelsen en relación con la fiscalización por el Tribunal Supremo de la constitucionalidad de las leyes (Teoría general del Derecho y del Estado, Universidad Nacional Autónoma de México, México, 1986, pgs.318-319).

(53) Carré de Malberg, ob.cit., tomo II, pgs.36 y stes.; S.Alvarez Gendín: La independencia del poder judicial. La especialización de los tribunales contencioso-administrativos, Instituto de Estudios Políticos, Madrid, 1966, pg.34; L.Sánchez Agesta: Curso de Derecho constitucional comparado, Madrid, 1973, pgs.175 y stes. 
(54) Michel Troper: La séparation des pouvoirs et l'histoire constitutionnelle française, Paris, 1980 , pgs. 182 y stes.

(55) Duguit, Traité, tomo II, pg.680; Sánchez Agesta, Curso, pgs.57 y 59; Lucas Verdú, Curso, vol.2, pg.132.

(56) Duguit, Traité, tomo II, pgs.662 y 675; pero Duguit no alcanza, ni mucho menos, a cumplir con esta tarea, sino todo lo contrario: se aleja de ella como veremos.

(57) N.Pérez Serrano: Tratado de Derecho Político, Civitas, Madrid, 2a Ed., 1984, pg.379; y M.García Pelayo: Las transformaciones..., pgs.57 y stes. Por contra, Alvarez Gendín afirma que el principio subsiste hoy y que, además, "revela una indiscutible solidez sustancial" (ob.cit., pg.21).

(58) A.Agúndez: Historia del poder judicial en España, Ed.Nacional, Madrid, 1974, pg.107; F.Ledesma Bartret: Discurso ante el Pleno del Congreso de los Diputados el 13 de noviembre de 1984 en la presentación del proyecto de Ley Orgánica del Poder Judicial, reproducido en Documentación Jurídica, núm. 47-48, julio-diciembre de 1985, tomo XII, pg.367; C.M.Entrena Klett: "Vigencia actual del principio de separación de poderes: poder judicial y función jurisdiccional", Primeras Jornadas de Derecho Judicial, Tribunal Supremo, Madrid, 1983, pg.15; Carlos de Cabo: Revisión histórico-crítica de la doctrina de la soberanía, Salamanca, 1980, pg.33.

(59) Jellinek, Teoría general, pgs.374-375; Duguit, Traité, tomo II, pg.668; Loewenstein, ob.cit., pg.55; especialmente la independencia se ha predicado del poder judicial, así v.gr. Carré de Malberg, ob.cit., tomo II, pg.35; V.Fairén Guillén: Comentarios a la Ley Orgánica del Poder Judicial de 1 de julio de 1985, Edersa, Madrid, 1986, pg.31; J.L.Albácar López: "Naturaleza jurídica del Consejo General del Poder Judicial", Jornadas de Estudios sobre el Consejo General del Poder Judicial, Madrid, 1983, pg.114; S.Muñoz Machado: La reserva de jurisdicción, La Ley, Madrid, 1990, pg.14; pero se ha llegado a hablar incluso de "aislamiento" de los tres poderes entre sí, A.Carretero Pérez: "El modelo del poder judicial en la Constitución”, El poder judicial, Instituto de Estudios Fiscales, Madrid, 1983, tomo I, pg.744.

(60) "El parlamento debe tener todo lo legislativo, el rey todo lo ejecutivo y solamente el ejecutivo, el orden judicial todo lo judicial y solamente lo judicial, en fin que cada uno de esos órganos debe permanecer aislado e independiente encerrado en el dominio en el que representa la voluntad nacional sin poder ejercer ninguna acción sobre los otros órganos" (Duguit, Traité, tomo II, pgs.673-674). En la misma línea, L.Sánchez Agesta: Historia del constitucionalismo español, Instituto de Estudios Políticos, Madrid, 1955, pg.90; J.V.Gimeno Sendra: Fundamentos del Derecho Procesal, Civitas, Madrid, 1981, pg.44; André Hauriou, ob.cit., pg.239; Lucas Verdú, Curso, vol.2, pg.126; García Pelayo, "Las transformaciones..., pg.58; un resumen del estado pacífico -por más que erróneo a mi entender- de la cuestión, ha sido trazado por J.Rodríguez-Zapata Pérez: "El poder judicial como límite de la potestad de control de las Cortes generales", en El poder judicial, cit., tomo III, pg.2456.

(61) "No se acordará ninguna excepción, bajo el título que sea, en un gobierno bien organizado" (Rousseau, Discours sur l'économie politique, pg.66). "La facultad de suspender las leyes o su ejecución sólo deberá ser ejercida por el cuerpo legislativo o por la autoridad que de él derive, y se utilizará sólo en aquellos casos particulares que el cuerpo legislativo expresamente estipule" (art.20 de la Declaración de Derechos de Massachsetts).

(62) "Todo estaría perdido si el mismo hombre, el mismo cuerpo de personas principales, de los nobles o del pueblo, ejerciera los tres poderes: el de hacer leyes, el de ejecutar las resoluciones públicas y el juzgar los delitos o las diferencias entre particulares" (Montesquieu, XI-6, pgs.151-152); en Estados Unidos, escribía Paine, todos estaban de acuerdo en que debía haber constitución: "Al llegar a sus partes componentes es cuando se dividen las opiniones... Aunque todas las Constituciones de América se basan en los mismos principios, no hay dos completamente iguales en sus componentes o en la distribución de los poderes que otorgan a los actuales gobiernos" (Los derechos del hombre, Orbis, Barcelona, 1985, pg.158). También en relación con la Constitución estadounidense, vid. El federalista, pgs.204 y stes. Kelsen apuntó que el principio iba más contra la concentración de poderes que en pro de su 
separación (Teoría general, pg.334). En términos más precisos, Pedraz Penalva, Formación, pgs.334-335.

(63) Flórez Estrada, En defensa..., pgs.46-47;J.L. Villar Palasí: Derecho Administrativo. Introducción y teoría de las normas, Universidad de Madrid, 1968, pgs.141 y stes.; Pedraz Penalva: "La jurisdicción...", pgs.911-912. En contra, aunque en este punto incurre también en contradicción, Carré de Malberg, ob.cit., tomo II, pg.8 y J.A.Santamaría Pastor: Sobre la génesis del Derecho Administrativo español en el siglo XIX (1812-1845), Sevilla, 1973, pg.33, quien se refiere a la contradicción que -en su opinión- concurre entre la separación de poderes y la supremacía de la ley, refiriéndose expresamente al primer Decreto emanado de las Cortes de Cádiz. Naturalmente asumen esta misma posición los que entienden los poderes como iguales e independientes, como Pérez Serrano, Tratado, pg.373 que, sin embargo, rectifica más adelante (pg.381) y Tomás y Valiente, Manual, pg.426.

(64) "El mandatario público -escribió Sieyes- fuere cual fuere su cargo en los diversos niveles de los poderes públicos, no ejerce en modo alguno un poder ve le pertenezca en propiedad, sino que ejerce muy diferentemente, un poder cuya titularidad corresponde a todos los ciudadanos y le ha sido meramente confiado... Constituye, pues, un craso error creer que una función pública pueda devenir jamás propiedad privada de alguien y que un poder público pase a ser considerado como un derecho cuando en realidad no es sino un deber" (Escritos y discursos, pgs.102-103).

(65) Vid. Lord Brougham: De la democratie et des gouvernements mixtes, Paris, 1872; Joaquín Varela Suances-Carpegna: Tradición y liberalismo en Martínez Marina, Oviedo, 1983, pgs.40 y stes.; y N.Bobbio: La teoría de las formas de gobierno en la historia del pensamiento político, Fondo de Cultura Económica, México, 1989.

(66) E.Fouzier-Herman: La separation des pouvoirs, Paris, 1880, pg.305.

(67) "Un pueblo es un pueblo antes de darse a un rey", afirma Rousseau (Del contrato social, I5, pg.21). En Estados Unidos, a diferencia de Europa, según Paine, no "existe la menor idea de convenio entre el pueblo por un lado y el gobierno por otro. El convenio existía dentro del pueblo para crear y constituir un gobierno. Suponer que ningún gobierno pueda ser parte de un convenio con todo el pueblo es pensar que ha existido antes de tener derecho a ello" (Los derechos del hombre, pg.151). Este es el pensamiento de los jacobinos en general, y de Saint Just en particular: vid. Bernat Muniesa: El discurso jacobino en la revolución francesa, Ariel, Barcelona, 1987, pg.115.

(68) Del contrato social, III-1, pg.62; las palabras de Rousseau son muy contundentes en este punto: "Algunos han pretendido que el acto de esta institución era un contrato entre el pueblo y los jefes que él se da; contrato por el cual se estipulaban entre las dos partes las condiciones bajo las que una se obligaba a mandar y la otra a obedecer. No dudo que se me concederá que ésa es una extraña manera de contratar... Es absurdo y contradictorio que el soberano se dé a sí mismo un superior; obligarse a obedecer a un amo es entregarse en plena libertad. Además es evidente que este contrato del pueblo con tales o cuales personas sería un acto particular. De donde se sigue que este contrato no podría ser ni una ley ni un acto de soberanía, y que por consiguiente sería ilegítimo. No hay más que un contrato en el Estado, es el de la asociación; y éste solo excluye cualquier otro. No podría imaginarse ningún contrato público que no fuera una violación del primero" (Del contrato social, III-16, pg.101).

(69) Sucede lo mismo que en los regímenes presidencialistas, como el estadounidense, donde la elección por sufragio impide la destitución desde las cámaras, con la salvedad del "impeachment", es decir, de la responsabilidad criminal.

(70) Según Duvergier de Hauranne, el comité constitucional concedió "al cuerpo legislativo el derecho de acusar a los ministros; pero había comprendido que ese derecho era ilusorio si únicamente se reservaba a los casos de prevaricación. Un ministro, en efecto, sin hacerse culpable de traición o de concusión, puede, por negligencia o por incapacidad, comprometer al más alto nivel los intereses del Estado. El comité había, pues, admitido que los ministros podían ser acusados por negligencia, por incapacidad y en ese caso, condenados solamente a la destitución. Pero el comité había olvidado dos cosas: la primera, que la negligencia y la 
incapacidad son poco susceptibles de demostración rigurosa como para que un tribunal pueda quedar satisfecho; segunda, que el tribunal o el jurado nacional encargado, no de determinar sobre crímenes o delitos positivos, sino de apreciar la inteligencia y la conducta de los ministros, se convierte por fuerza de las cosas, en el primer poder del Estado" (Histoire du gouvernement parlementaire en France 1814-1848, Paris, 1857, tomo I, pgs.265-266). Vid. J.M.Olarieta Alberdi: "La autorización administrativa previa para procesar a los funcionarios públicos", Revista de Estudios de Administración Local y Autonómica, núm.246, abril-junio de 1990, pgs.240-241.

(71) Precisemos, no obstante, que Rousseau distinguió gobierno mixto de moderado: Del contrato social, III-7, pg.84.

(72) Troper, ob.cit., pgs.158-159.

(73) Parece desmentir esta tesis el art.30 de la Declaración de Derechos de Massachusetts; pero se trata de una formulación muy estricta que no se ha repetido, que sepamos, favorecida por tratarse de una Declaración de Derechos precisamente, y no de una constitución. Por otro lado, hace superfluos los arts. 25 y 28 de esa misma Declaración.

(74) Choix, tomo I,pgs.255 y stes. Esta misma idea fue contundentemente plasmada en el art.26 de la Constitución belga de 1830: "El Rey, la Cámara de los representantes y el Senado ejercen colectivamente el poder legislativo", expresión idéntica al art.15 de la Carta francesa de 1814, art.14 de la de 1830 y art.62 de la Constitución prusiana de 1850.

(75) "En el gobierno republicano predomina necesariamente la autoridad legislativa. El remedio de este inconveniente consiste en dividir la legislatura en ramas diferentes, procurando por medio de diferentes sistemas de elección y de diferentes principios de acción, que estén tan poco relacionados entre sí como lo permita común de sus funciones y su común dependencia de la sociedad" (El federalista, pg.221).

(76) Art.1-IV-III.

(77) "La parte que se ha dado al Rey en la autoridad legislativa, concediéndole la sanción, tiene por objeto corregir y depurar cuando sea posible, el carácter impetuoso que necesariamente domina en un cuerpo numeroso que delibera sobre materias las más de las veces muy propias para empeñar al mismo tiempo las virtudes y los defectos del ánimo" (Colección de leyes fundamentales, pg.44). El veto no era, en consecuencia, contrario ni una excepción a la separación de poderes; por contra, constituía su misma garantía en el sistema mixto, como afirmó Kelsen (Teoría general, pg.322). Para probarlo basta leer las primeras líneas del informe de Lally-Tollendal: el rey era una "porción" del poder legislativo. Para Sieyes, el derecho de impedir, del que formaba parte el de veto, no era esencialmente diferente del derecho de estatuir: uno y otro constituían facultades de naturaleza legislativa (discurso ante la Asamblea Nacional el 7 de setiembre de 1789). En esta línea, Carré de Malberg, ob.cit., tomo II, pgs.27 y 37, aunque en el tomo I, pags.399 y stes. parece seguir la opinión contraria. No faltan autores que niegan que el veto signifique que el rey es un órgano legislativo, máxime teniendo en cuenta que se trata de un veto meramente suspensivo. Agúndez, por ejemplo, ha minimizado su significación, calificándolo de "decorativo" y "simbólica reliquia": según él, "nada corrige ni depura" (ob.cit., pg.101). Ya Bodino expuso: "Hay gran diferencia entre mandato e impedimento u oposición; los colegas no tienen poder uno sobre el otro y, sin embargo, uno puede oponerse al otro" (Los seis libros de la República, citamos de la selección y traducción del Instituto de Estudios Políticos, Caracas, 1966, pg.244). En efecto, el veto es también una institución importada del Derecho Romano, cuyas magistraturas eran esencialmente colegiadas y, como ha escrito D'Ors, "la colegialidad consiste en que siendo el 'imperium' un poder absoluto en sí mismo, queda limitado por el veto ('intercessio') del magistrado de igual poder ('collega'). Esta igualdad de poder admite todavía una diferencia de rango, pero no una propia delimitación territorial" (ob.cit., pgs.52-53). Para Sieyes el poder de estatuir y el de impedir son iguales (Escritos y discursos, pg.114).

(78) En cuanto a la facultad reglamentaria del rey, el contraste entre la Constitución de Cádiz y la francesa de 1791 es total (vid. Alejandro Nieto, Estudios, pg.159); esta diferencia, y otras que encontraremos, pese a las claras continuidades observables entre ambas, permiten dudar 
fundadamente de la opinión de que la de 1812 sea copia de la 1791, como se ha sostenido por Federico Suárez y su escuela (v.gr. su artículo "Sobre las raíces de las reformas de las Cortes de Cádiz", Revista de Estudios Políticos, núm.126, noviembre-diciembre 1962, pgs.31 a 69).

(79) La interpretación de las leyes, función jurisdiccional, es atribuída al poder legislativo en la revolución burguesa. En los Estados Unidos se atribuye al Tribunal Supremo, pero hay que tener en cuenta que este órgano se concibe allí como parte integrante -o por lo menos al mismo nivel- que los demás órganos legislativos, el presidente y las cámaras. De cualquier forma, allí la Constitución se concibe de forma distinta que en Europa continental; se concibe como ley fundamental, pero ley al fin y a la postre. Es la nación quien elabora la constitución, mientras que las leyes ordinarias dimanan de un poder inferior, el legislativo. Las leyes ordinarias deben acomodarse a la constitución, y son los jueces -o mejor, el Tribunal Supremoquien debe realizar ese examen de constitucionalidad de las leyes: deben aplicar la constitución e interpretarla lo mismo que aplican e interpretan la legislación ordinaria. Esto convierte -a mi modo de ver- al Tribunal Supremo en un órgano cuasi-legislativo, del mismo rango que el legislador ordinario, en un "legislador negativo" con una "facultad de impedir" que no es, en definitiva, distinta del veto presidencial. La técnica es similar a la del recurso de casación puro, tal y como aparece en Francia, como forma de control de la legalidad de las resoluciones judiciales: el Tribunal de Casación no dictaba sentencia, sino que anulaba la del tribunal "a quo". Nos parece importante insistir en ello para remarcar el amplio uso que aquellos primeros constituyentes hicieron de este tipo de técnicas jurídicas formales o negativas herederas de la "intercessio" romana.

(80) Destacaríamos también, de manera especial, las facultades jurisdiccionales de las Cortes en materia de libertad de imprenta a través de las Juntas de Censura. Y en Francia, el Tribunal de Casación se constituye como un "anexo" del poder legislativo, no como un órgano integrante del poder judicial. "Quien hace la ley sabe mejor que nadie cómo debe ser ejecutada e interpretada", afirma Rousseau (Del contrato social, III-4, pg.71). En el Discurso Preliminar de 1811 se habla de la "inmediación" del Tribunal Supremo al gobierno (Colección de leyes fundamentales, pg.55).

(81) Para Santamaría Pastor (ob.cit., pg.42) las únicas intervenciones del ejecutivo en el judicial son las facultades de indulto y el nombramiento y suspensión de magistrados. Para Pedraz Panalva las únicas son la administración de justicia en nombre del rey y la estricta sumisión a la ley de los tribunales (Formación, pg.394). Según Muñoz Machado "desde los orígenes del constitucionalismo las Constituciones han proclamado la prohibición de que el Legislativo o el Ejecutivo juzguen" (ob.cit., pg.8). En parecidos términos, F.Tomás y Valiente: "De la administración de justicia al poder judicial", El poder judicial en el bicentenario de la revolución francesa, Ministerio de Justicia, Madrid, 1990, pgs.23 y 26. Esto es un tópico que no resiste el menor contraste fáctico. Por no redundar en el propio articulado constitucional, recordemos el art.13 del Decreto de abolición de los señoríos que obligaba a los tribunales a "consultar" con el rey las dudas que tuvieran en su aplicación, lo que demuestra tanto la naturaleza legislativa del rey, como la ausencia de especialización de los poderes.

(82) ¿Qué es el tercer estado?, Aguilar, Madrid, 1973, pg.77.

(83) Uno de los pocos rechazados por Robespierre de su maestro: El discurso jacobino..., pg.75.

(84) La ley tenía, pues, esas dos funciones: en cuanto a los poderes, significaba un mandato emanado del poder supremo; en cuanto a las relaciones con la sociedad, acotaba los derechos individuales (A.Nieto, Estudios, pgs.153 y stes.)

(85) La declaración de derechos, afirmó Mirabeau- no podía adoptar la forma de ley (Choix, tomo I, pg.230). Idénticamente, según Sieyes, no se trata de leyes "sino muy diferentemente, un conjunto de principios" (Escritos y discursos, pg.85).

(86) Escritos y discursos, pgs.99-100.

(87) Del contrato social, III-9, pg.90.

(88) Escritos y discursos, pg.91. 
(89) Del contrato social, III-11, pg.92; vid. Joaquín Varela, “La teoría del Estado...., pgs.307 y stes.

(90) El discurso jacobino..., pg.83.

(91) Filosofía del Derecho, pg.349.

(92) Mientras que, por el contrario, sí se enuncian una serie de deberes y obligaciones de los españoles en los arts.6 a 9 de la Constitución. Los "derechos" que de forma dispersa se enuncian a lo largo del articulado más que una Declaración encubierta constituyen derivaciones de un cierto modo de funcionamiento de los poderes, especialmente del poder judicial.

(93) Las transformaciones..., pg.21.

(94) Manual, pgs.422 a 424.

(95) En las antípodas de esta interpretación, Tomás y Valiente, "De la administración de justicia...", Bicentenario, pg.22.

(96) Troper, ob.cit., pgs.114 a 120.

(97) Estudios, pg.153.

(98) Cfr. Rousseau (Del contrato social, III-1, pg.61). "El cuerpo político, tomado individualmente -dirá en otra obra Rousseau- puede ser considerado como un cuerpo organizado, vivo y parecido al del hombre. El poder soberano representa la cabeza; las leyes y costumbres son el cerebro, principio de los nervios y sede del entendimiento, de la voluntad y de los sentidos, cuyos jueces y magistrados son los órganos" (Discours sur l'économie politique, pgs.60-61). Sieyes hablaba igualmente de dos tipos de cuerpos en la constitución, el "cuerpo legislativo" y los "cuerpos activos"; en parecidos términos Lanjuinais aludió a unos poderes encargados de pensar y de formar la voluntad, y otros encaminados a la acción y ejecución (ob.cit., tomo I, pgs.181 y stes.). Por todas partes se constata la equiparación del Estado con el cuerpo humano: el Estado es un organismo, según Hegel, y "la voluntad del Estado es voluntad humana" dirá Jellinek (Teoría general, pg.315).En idénticos términos, Sieyes, Escritos y discursos, pg.99. Para Robespierre "la fuerza pública es al cuerpo político lo que es al cuerpo el brazo que ejecuta espontáneamente lo que la voluntad le dicta y rechaza todos los objetos que pueden amenazar al corazón o la cabeza" (El discurso jacobino..., pg.84). Los propulsores de las constituciones especializadas, y en primer término Rousseau, fueron quienes dejaron claramente expuesto este punto, que nos parece crucial, mientras que Locke y Montesquieu, en su preocupación por el pacto interclasista, resultan aquí inconsecuentes.

(99) Colección de leyes fundamentales, pgs.36-37.

(100) "En lo que concierne a la ejecución de las leyes, lo que se llama el poder judicial es estricta y propiamente el poder ejecutivo de cada país. A ese poder es al que ha de apelar cada individuo, y el que hace que la ley sea ejecutada". Y más adelante añade: "Se llamaba poder ejecutivo porque antiguamente la persona que lo ejercía acostumbraba a dirigir con categoría de juez la administración y ejecución de las leyes. Los tribunales eran entonces una parte de la administración y ejecución de las leyes. Los tribunales eran entonces una parte de la corte $y$, por lo tanto, el poder que ahora se llama judicial, era por aquella época llamado ejecutivo" (Los derechos del hombre, pgs. 158 y 182).

(101) Choix, tomo III, pg.229; Kelsen ha sostenido en la actualidad esta misma idea (Teoría general, pgs.306, 323, y 325).

(102) "Cuando corrientemente se habla de tres poderes, el legislativo, el ejecutivo y el judicial, el primero corresponde a la universalidad y el segundo a la particularidad; el judicial, en cambio, no es el tercer momento del concepto, ya que su individualidad está fuera de aquellas esferas" (Filosofía del Derecho, pg.353).

(103) También aquí Duguit sostuvo un criterio contrario: sí existe -según el profesor de Burdeos- una función jurisdiccional distinta de la ley y de su ejecución (Traité, tomo II, pgs.418 
y stes.) tanto formal, por el órgano de procedencia, como materialmente. La define como "el acto de orden jurídico cumplimentado por una agente público como consecuencia lógica de la constatación que ha hecho de que había o no violación del derecho objetivo o atentado contra una situación objetiva o a una situación subjetiva" (pg.423).

(104) Aspecto que ya fue reseñado por Aristóteles (La política, Espasa-Calpe, Madrid, 12 ${ }^{\mathrm{a}}$ Ed., 1974. pg.184).

(105) Vid. El federalista, pgs.211 y 221. De la exposición de Montesquieu se desprende ya, con cierta nitidez, la supervisión por la Asamblea de la acción gubernativa: "Si en un Estado libre el poder legislativo no debe tener derecho a frenar al poder ejecutivo, tiene, sin embargo, el derecho y debe tener la facultad de examinar cómo son cumplidas las leyes que ha promulgado" (ob.cit., XI-6, pg.155). Vid. Pedraz Penalva, Formación, pgs.332 y stes. y El discurso jacobino..., pgs.78-79. Pero es evidente que este aspecto está mucho más velado en Montesquieu que en Locke, más contundente al respecto. "El sistema constitucional del siglo XIX giraba, en efecto, a primera vista, en torno a la ley, a través de ella, el Parlamento aseguraba la dependencia de un ejecutivo que le estaba subordinado. El principio de legalidad nace, pues, con sustantividad propia, concretamente política, que nada tiene que ver, de momento, con el control del otro poder, del judicial. Su objetivo primario consiste, sencillamente, en someter al Poder ejecutivo a la soberanía del legislativo. Las Cortes que se arrogan la expresión exclusiva de la voluntad de la Nación, entienden que la Administración les está subordinada, y la legalidad es cabalmente el instrumento para hacer efectiva tal subordinación" (Alejandro Nieto, Ensayos, pg.153). De la supremacía del poder legislativo deriva precisamente la manida cuestión de la "limitación del poder", que no es otra cosa que la limitación del poder legislativo como poder supremo, y no del poder en abstracto. En Estados Unidos son limitaciones de ese poder tanto el veto del poder ejecutivo como el examen de constitucionalidad de las leyes del Tribunal Supremo.

(106) William Stubbs: Histoire constitutionelle de l'Angleterre, Paris, 1913, tomo II, pgs.622 y stes.

(107) Ibid, tomo II, pg.730.

(108) Troper, ob.cit., pg.82; Lair, ob.cit; también, E.Gordon: La responsabilité du Chef de l'Etat dans la pratique constitutionnelle récente, Paris, 1931.

(109) Ob.cit., pg.122.

(110) Ibid, pgs.139 y stes.; Duvergier de Hauranne, ob.cit., tomo I, pg.93.

(111) Choix, tomo I, pg.207.

(112) Duvergier de Hauranne, ob.cit., tomo I, pgs.95 y 99.

(113) Art.7, Capítulo II, que se transformó en el art.8-III-IV-II de la Constitución: cuando el rey suspendiera de sus funciones a los empleados públicos, informaría a la Asamblea" >la Asamblea, la cual podía confirmar o revocar dicho acuerdo "y si hubiera lugar, a los tribunales criminales, o interponer contra ellos el decreto de acusación".

(114) Duvergier de Hauranne, ob.cit., tomo I, pg.296.

(115) R.Flaquer Montequi ha deducido de aquí el diseño de un "gobierno de asamblea" por los doceañistas, lo que, en su opinión, contradice el principio de separación de poderes ("El ejecutivo en la revolución liberal", Las Cortes de Cádiz, Madrid, 1991, pgs.46 y 56-57).

(116) Las residencias, como los agravios, no son índices de modernidad, sino herencias del Antiguo Régimen: eran formas de control por el soberano de su política absolutista y centralista. Se basaban en que era el rey quien disponía de todos los poderes y todas las competencias y, por ello mismo, quien podía fiscalizar la forma en que los funcionarios -meros comisarios- ejecutaban sus disposiciones. Cfr. Luis Moreno Pastor: Los orígenes del Tribunal Supremo 1812-1838, Universidad Complutense de Madrid, 1988, (hay edición del Ministerio de Justicia), pgs.310 y 584-585; Villar Palasí, ob.cit., pg.144; y Nelson Durán: La Unión Liberal y la 
modernización de la España isabelina. Una convivencia frustrada 1854-1868, Akal, Madrid, 1979, pg.54.

(117) Este régimen de responsabilidades se ha llamado "sistema belga" por desarrollarse en la Constitución de 1830 de aquel país, cuando tiene su origen en la de Cádiz.

(118) Sánchez Agesta, "Poder ejecutivo...", pg.14.

(119) Vid. Flaquer Montequi, ob.cit., pg.61. En contra de esta tesis, Sánchez Agesta, "Poder ejecutivo..." pgs.23 a 25. Según este último autor, la responsabilidad política surge bajo el Estatuto Real. Nuestra discrepancia con Flaquer Montequi radica en que para él la responsabilidad política y el "gobierno de asamblea" contradicen la separación de poderes; para nosotros es una de sus formas.

(120) Que sin embargo sólo alcanzan a las "órdenes", pero no comprenden ni la omisión ni la negligencia, que son básicas en la responsabilidad política. Estos supuestos sólo se desarrollaron en leyes ordinarias.

(121) El de 24 de marzo trataba de la responsabilidad de magistrados y funcionarios; en el primer caso, si de magistrados del Tribunal Supremo se trataba, debían ser juzgados por un tribunal de nueve jueces nombrados por las Cortes, únicas que podían declarar que había lugar a incoar causa contra ellos "con lo cual quedarán en suspenso desde luego". En cuanto a los funcionarios, y más en concreto, respecto a los regentes, debían ser acusados ante las Cortes (los ministros ante éstas o la regencia), quienes debían declarar "con lo cual quedarán en suspenso" de sus cargos, por lo que la responsabilidad política no está aquí tan clara como en la Constitución. El Decreto de 8 de abril contenía un nuevo reglamento de la regencia, que traslada ya la responsabilidad a los ministros a quienes declara "responsables ante las Cortes".

(122) Filosofía del Derecho, pgs.351-352; en parecidos términos en las pgs.334 y 353.

(123) Vid. Piero Calamdrei: La cassazione civile, Turín, 1920, tomo I, pgs.420 y stes.

(124) Cfr. Moreno Pastor, ob.cit., especialmente pgs.43 a 75.

(125) "Las facultades de las Cortes se han expresado con individualidad para que en ningún caso pueda haber ocasión de disputa o competencia entre la autoridad de las Cortes y la del Rey, que no esté fácilmente disuelta con el simple recuerdo de la Constitución" (Colección de leyes fundamentales, pg.44).

(126) "De 1789 al año VIII fue a las Asambleas, órganos de la soberanía a quienes perteneció resolver en última instancia sobre los conflictos de competencia entre las autoridades administrativa y judicial" (Ernest Laferrière: Traité de la jurisdiction administrative et des recours contentieux, Paris, 1887, tomo I, pg.176). La afirmación de Laferrière no es, sin embargo, muy exacta porque quien comenzó a resolver sobre estos conflictos era el Tribunal de Casación, en virtud de la ley de 1 de diciembre de 1790; pero dicho Tribunal de Casación era, como hemos dicho, un "anexo" de la Asamblea legislativa.

(127) J.I.Marcuello Benedicto: "Las Cortes Generales y Extraordinarias", Las Cortes de Cádiz, ob.cit., pg.74.

(128) Ob.cit., XI-6, pg.155.

(129) Cours de politique constitutionnelle, Paris, 1818, tomo I, pg.31.

(130) Sieyes y Rousseau insistieron en estos dos aspectos concurrentes en el concepto de ley: su origen, la voluntad general, y su destino, el interés general: "Toda función que se refiera a un objeto individual -escribió por ejemplo Rousseau- no pertenece en modo alguno al poder legislativo" (Del contrato social, II-6, pg.44). "La voluntad general es siempre para el bien común" (Discours sur l'économie politique, pg.63). Para Sieyes la Asamblea "no está hecha para ocuparse de los asuntos particulares de los ciudadanos, no los considera sino en masa y desde el punto de vista del interés común" (¿Qué es el tercer estado?, pg.111). En términos 
equivalentes, Martínez Marina: Juicio crítico de la Novísima Recopilación, Madrid, 1820, pgs.210-211. Vid. también García Pelayo, Derecho Constitucional Comparado, pgs.68-69.

(131) Todos los actos de la Asamblea, exige Rousseau, "no pueden ser más que leyes" (Del contrato social, III-1, pg.62).

(132) Derecho Constitucional Comparado, pgs.154-155.

(133) De ahí que los primeros constituyentes franceses, en función de los bloques de competencias distribuídos, hablaran de un número variable de poderes. Maury y Cazàles sólo reconocían al legislativo y al ejecutivo; Mounier identificó a cuatro, los tres tradicionales y el "poder militar"; se impuso finalmente la postura de Barnave y los tres poderes tradicionales, no sin que algunos, como Duport, expusieran sus dudas respecto del poder judicial. Para LallyTollendal debían ser necesariamente tres los poderes porque si sólo fueran dos, entrarían en conflicto, dando lugar a una situación de inestabilidad, hasta que uno de ellos se impusiera al otro, degenerando en confusión de poderes, en despotismo. Tres era el número perfecto para el "equilibrio", y hasta Rousseau rescató el tribunado pretendiendo hacer de él un tercer poder intermitente y con facultad de impedir (Del contrato social, IV-5, pg.124). La cuestión del número de poderes, fruto de la mitología, ha dado lugar luego a toda suerte de especulaciones febriles. Se ha hablado del rey como poder moderador (Constant, Lanjuinais), de un poder de sufragio (Hauriou), de la prensa como cuarto poder, del poder sindical, del administrativo, del militar, del municipal, o de la existencia de nada menos que ocho poderes (Romagnossi). Todo esto nos retorna a la situación anterior a Locke y Montesquieu, a confundir las arcaicas clasificaciones de las actividades del Estado, con la división de poderes, que está establecida sobre una base formal y no material: toman, como ya advirtió Rousseau, por partes de la autoridad lo que no son más que sus emanaciones (Del contrato social, II-2, pg.34).

(134) El Derecho público del Imperio alemán, tomo IV, Cap.XIII, par.84

(135) Ob.cit., tomo II, pg.34

(136) Principios de Derecho Público y Constitucional, Madrid, 1927, pg.335.

(137) La defensa de la constitución, Labor, Madrid, 1931, pgs.33 y 51.

(138) Cfr. F.Tomás y Valiente: "Venta de oficios públicos en Castilla durante los siglos XVII y XVIII", en Gobierno e instituciones en la España del Antiguo Régimen, Alianza, Madrid, 1982, pgs.151 y stes.; según Pedraz Penalva no existió venta de oficios judiciales en Castilla (Formación, pgs.281 y stes. y 450); para Inglaterra, W.Stubbs, ob.cit., tomo II, pgs.680 y stes.; con carácter más general Alejandro Nieto, La burocracia, pgs.167 y stes.

(139) A.Tocqueville: El Antiguo Régimen y la revolución, Guadarrama, Madrid, 1969, pg.147; en nuestro país Juan de Mariana hablaba de la existencia en la Administración de "nombres de destino sin objeto" (Del rey y de la institución de la dignidad real, Madrid, 1845, pg.265).

(140) Que Madison (El federalista, pg.174) y Paine (Los derechos del hombre, pg.59), lo mismo que Montesquieu, relacionaron estrechamente: la guerra era el gasto público más importante, cuya financiación satisfacía la burguesía; desarrollaba poderosos ejércitos que el rey y la aristocracia controlaban, permaneciendo al margen los nuevos segmentos sociales emergentes del capitalismo.

(141) Colección de leyes fundamentales, pgs.37 y 38.

(142) Villar Palasí, ob.cit., pg. 143.

(143) Como observó Schmitt, el reparto constitucional de competencias material y limitado es inservible con un concepto formal de ley (La dictadura, pgs.140 y 141).

(144) J.García Fernández ha calificado de "enigma" esta intervención de las Cortes en la aprobación de las ordenanzas municipales, lo que "supone una quiebra llamativísima del sistema de inserción de la administración local en el poder ejecutivo, que no contribuía a esclarecer de ninguna manera la aplicación del principio de separación de poderes a la esfera 
local" (El origen del municipio constitucional, Instituto de Estudios de Administración Local, Madrid, 1983, pgs.271 y 291 y stes). Considera, además, que este tipo de disposiciones son de naturaleza administrativa (pg.57) y no legislativa, como afirmó Duguit (Traité, tomo II, pgs.209 y stes).

(145) Según Carré de Malberg (ob.cit., tomo II, pg.28) Montesquieu dio una concepción material de los poderes y, en cuanto a la competencia, Duguit ha expuesto que mientras la Asamblea de 1789 tenía una "idea flotante" al respecto, la de 1793 opta por un reparto formal (Traité, tomo II, pg.162). Por contra, Troper ha escrito que en tanto los constituyentes de 1791 tenían una noción formal de la distribución de las competencias, los jacobinos la tenían material (ob.cit., pgs.20, 102-103, 175-176 y 185); mi opinión es exactamente la inversa, pero matizadamente respecto de la Constitución de 1793.

(146) "La constitución es racional en la medida en que el estado determina y diferencia en sí su actividad de acuerdo con la naturaleza del concepto, de manera tal que cada uno de los poderes es en sí mismo la totalidad, porque contiene en sí la actividad de los otros momentos y porque, al expresar éstos la diferencia del concepto, se mantienen en su idealidad y constituyen un único todo individual... Los poderes del estado tienen, por supuesto, que diferenciarse, pero cada uno debe formar en sí mismo un todo y contener en sí a los otros momentos. Cuando se habla de la diferente esfera de acción de los poderes, no hay que caer en el enorme error de comprenderlo como si cada poder existiera por sí de modo abstracto, ya que los poderes sólo deben diferenciarse en cuanto momentos del concepto... De lo que se trata, por consiguiente, es de que los poderes, ya que sus determinaciones son en sí el todo, también en la existencia constituyan la totalidad del concepto" (Filosofía del Derecho, pgs.350 y 353).

(147) Carl Schmitt, además de reiterar en sus obras esta distinción, destacó el empleo político en la Alemania>la Alemania del siglo XIX de las leyes formales como "expresión de una pura ampliación política de poderes", como "medio de lucha de la burguesía con la monarquía constitucional", cuyo objetivo era "extender frente a un Gobierno no parlamentario el ámbito de poder del Parlamento respecto a acontecimientos y procesos importantes en el aspecto jurídico-financiero", poniendo de manifiesto que sólo pueden "sustraerse al poder del rey determinados sectores y asuntos reservándolos al legislador” (La defensa..., pg.159).

(148) Como sostiene Santamaría Pastor (ob.cit., pg.34). Para Flaquer Montequi se trataría del tránsito de un gobierno de asamblea o convencional, a otro de separación de poderes (ob.cit., pgs.61 a 63).

(149) V.gr. Carré de Malberg, ob.cit., tomo II, pg.7; Loewenstein, ob.cit., pg.55; García Pelayo, Derecho Constitucional Comparado, pg.154; C.Conde-Pumpido: "Justicia-poder", Revista de Derecho Judicial, 1960, núm. 4, pg.137; F.Tomás y Valiente: "La Constitución de 1978 y la historia del constitucionalismo español", en Códigos y constituciones, Alianza, Madrid, 1989, pg.126; J.M.Serrano Alberca, con Garrido Falla y otros: Comentarios a la Constitución, Civitas, Madrid, 1980, pg.1182; R.Calzada Conde: "El principio configurador y garantista en la Constitución de Cádiz", en Materiales para el estudio de la Constitución de 1812, Madrid, 1989, pg.154; Pérez Serrano ha afirmado que la separación de poderes era "la máxima garantía de la libertad" (Tratado, pg.374) no especificando, a qué libertad se refiere, pero aludiendo a las libertades ciudadanas en general (pg.369); en iguales términos Duguit, Traité, tomo II, pgs.663 y 664 .

(150) Montesquieu, ob.cit., XI-18 y XII-1, pgs.169 y 172-173; así parecen probarlo en España disposiciones tales como el Decreto de 23 de junio de 1813, que obligaba a los habitantes dispersos por los valles y montes a concentrarse en los núcleos de población, abandonando su vivienda y trabajo habitual.

(151) Colección de leyes fundamentales, pg.49

(152) Solé Tura y E.Aja, Constituciones y periodos constituyentes, pg.16; interpretado como "transitoriedad de la división de poderes" en Pedraz Panalva, Formación, pgs.71 y 377 . "El interés de la burguesía se centró en primera instancia en coger en sus propias manos la legislación para debilitar así, mediante la división de poderes, el poder de los príncipes. 
Ciertamente que esta solución constitucional sólo podía constituir una fase de transición. La lógica interna de la idea liberal, lo mismo que la inexorabilidad social, tenía que conducir a la fase en que el ejecutivo quedara bajo la representación popular" (Reinhard Kühnl: "Liberalismo y fascismo. Dos formas de dominio burgués, Fontanella, Barcelona, 2ª Ed., 1982, pg.43)

(153) La diferenciación envuelve una tradicional disputa, cuya génesis radica en la noción de "universitas" en el Derecho Romano, y que recuperará el nominalismo en el ámbito filosófico. Burke la utilizó de forma oportunista para criticar las declaraciones derechos: si un pueblo tiene derechos es que ya se ha creado una entidad artificial, por lo que cada miembro renuncia a sus derechos individuales; y a la inversa, si estos perviven es porque aún no se ha formado esa unidad corporativa capaz de asumir derechos por sí misma (C.B.MacPherson: Burke, Alianza, Madrid, 1980, pg.71)

(154) "Ruego a mis lectores -advertía Rousseau- que distingan bien entre la economía política de la que tengo que hablar, y que llamo gobierno, de la autoridad suprema que llamo soberanía; distinción que consiste en que una tiene el derecho legislativo y obliga en ciertos casos al cuerpo mismo de la nación, mientras la otra no tiene más que el poder ejecutor, y no puede obligar más que a los particulares" (Discours sur l'économie politique, pg.61).

(155) Escritos y discursos, pgs.100-101

(156) Filosofía del Derecho, pg.374

(157) Según Hobbes "la libertad de la cual se hace mención tan frecuente y honrosa en las historias y en la filosofía de los antiguos griegos y romanos, y en los escritos y discursos de quienes de ellos han recibido toda su educación en materia de política, no es de la libertad de los hombres particulares, sino de la libertad del Estado, que coincide con la que cada hombre tendría si no existieran leyes civiles ni Estado en absoluto" (Leviatán, II-21). En términos parecidos: Duguit, Traité, tomo I, pgs.174-175.

(158) Metafísica de las costumbres, pgs.144-145

(159) "La palabra libertad no se refiere a los particulares, sino al Estado... Cuando los particulares o los súbditos piden libertad, con esta palabra no entienden libertad sino poder... Si se desea ser libre mientras los demás son esclavos ¿qué otra cosa se pretende sino el poder? Todo aquel que es libre ha de ser dueño de todos aquellos que están sometidos. Así pues, la libertad de los particulares no es mayor en el Estado popular que el monárquico. Lo que desea el vulgo es que todos participen por igual en los cargos públicos y en la autoridad del mando. Donde el pueblo gobierna, cada uno participa en el derecho a los cargos públicos, que son igualmente compartidos, y cada uno tiene voto para elegir a los magistrados y demás funcionarios de la república... Los súbditos que se quejan de la pérdida de su libertad bajo la dominación de un monarca legítimo no tienen ninguna otra causa verdadera de protesta que el deseo de participar en el gobierno del Estado" (Thomas Hobbes: De cive, X-8).

(160) Sin embargo, en contra de esta tesis, Tomás y Valiente opina que, por el contrario, "la preocupación dominante en el protoliberalismo consiste en afirmar la libertad política de la Nación" (Códigos y constituciones, pg.154). A mi modo de ver, la libertad política era instrumental respecto de la privada.

(161) El individualismo burgués no era más que la otra cara del la "neutralidad" del Estado liberal, de su "apoliticismo". Al respecto, García Pelayo, Derecho Costitucional Comparado, pgs.143-144.

(162) La democracia..., I-2-32, pg.259; y en otro escrito apuntó igualmente: "Nuestros antepasados carecían de la palabra individualismo que nosotros hemos forjado para nuestro uso, porque en su época no había, en efecto, ningún individuo que no perteneciese a un grupo y que pudiese considerarse absolutamente aislado; pero cada uno de estos mil grupos de que se compone la sociedad no pensaba más que en sí mismo. Era, si puedo expresarme así, una especie de individualismo colectivo, que preparaba las almas para el verdadero individualismo que conocemos hoy en día" (El Antiguo Régimen, pg.137). Vid. Ernst Cassirer, ob.cit., pg.180.

(163) Colección de leyes fundamentales, pg.49 
(164) Carl Schmitt, Estudios políticos, pg.157.

(165) La democracia..., I-II-32, pg.328.

(166) En este punto, aunque no sea muy consecuente, Carré de Malberg afirma que lo poderes jurídicamente constituídos no son iguales, sino que están jerarquizados: "Es imposible concebir -afirma- que no haya en el Estado más que poderes iguales. La unidad estatal se encontraría rota de ese modo. Y es por ello que en todo Estado, incluso en los que la Constitución trata de apoyarse en la teoría de Montesquieu y pretende una cierta igualación de poderes, se encontrará invariablemente un órgano supremo, que domina a todos los demás y que realiza la unidad del Estado". Por otra parte, para él la supremacía del poder de dominación y de la unidad del Estado no se verifica sólo en los momentos de revisión constitucional: "En todo tiempo -dice- es indispensable que haya en el Estado un 'centro' único de voluntad, es decir, un órgano superior cuyo papel será preponderante, bien porque este órgano tenga el poder de imponer de forma inicial su voluntad a las otras autoridades estatales, bien porque, como mínimo, nada pueda hacerse sin el concurso de la libre voluntad. Solamente con esta condición la unidad del Estado se mantiene: se arruinaría si coexistieran en él dos centros principales, dos voluntades diferentes e iguales" (ob.cit., tomo I, pgs.52 y 56).

(167) "La idea de un gobierno nacional lleva en sí no sólo una potestad sobre los ciudadanos individuales, sino una supremacía indefinida sobre todas las personas y las cosas, en tanto que son objetos lícitos del gobierno. En el caso de un pueblo consolidado en una sola nación, esta supremacía está íntegramente en posesión de la legislatura nacional. En el caso de varias comunidades que se unen para finalidades especiales, se encuentra en parte depositada en la legislatura general y en parte en las legislaturas municipales" (El federalista, pg.162). Vid. también Kelsen, Teoría general, pg.226; Maurice Hauriou: Précis de Droit Administratif et de Droit Public, Paris, 1933, pg.8; Jellinek, Teoría general, pgs.304 y stes.; y García de Enterría, Legislación delegada..., pgs.98 y stes.

(168) Ob.cit., IV-7, pgs.82-83.

(169) De cive, X-16.

(170) Ensayo sobre los privilegios, Alianza, Madrid, 1989, pgs.64 a 66

(171) "La fuerza no hace derecho, y sólo se está obligado a obedecer a los poderes legítimos" (Del contrato social, I-3, pg.14). Según el art.11 de la Declaración jacobina "todo acto ejercitado contra un hombre fuera de los casos y sin las formas que la ley determina, es arbitrario y tiránico; aquel contra el que se pretenda ejecutarlo tiene derecho a repelerlo por la fuerza".

(172) "El catolicismo, divinizando la autoridad, santificó la obediencia; y santificando la una y divinizando la otra, condenó el orgullo en sus manifestaciones más tremendas, en el espíritu de dominación y en el espíritu de rebeldía" (J.Donoso Cortés: Ensayo sobre el catolicismo, el liberalismo y el socialismo, Espasa-Calpe, Madrid, 3ª Ed., 1973, pg.25).

(173) Figgis, ob.cit., pgs.157 y stes.

(174) "El súbdito jamás está autorizado a atentar contra su príncipe soberano, por perverso cruel y tirano que sea" (Los seis libros de la República, II-5, pg.200).

(175) "Quien ha transferido a otro, espontáneamente o por la fuerza, su poder de defenderse, le cedió completamente su derecho natural y decidió, por tanto, obedecerle plenamente en todo; y está obligado a hacerlo sin reservas" (Tratado teológico-político, Alianza, Madrid, 1986, pg.342).

(176) "En cualquier comunidad o república ningún hombre tiene derecho a oponer resistencia a la persona o personas a quienes ha conferido este poder coercitivo o (como se suele decir) la espada de la justicia, suponiendo posible la no-resistencia" (Elementos de Derecho natural y político, Centro de Estudios Constitucionales, Madrid, 1979, pgs.258-259).

(177) Ob.cit., pgs.65 a 87. 
(178) "La comunidad conserva perpetuamente el poder supremo de sustraerse a las tentativas y maquinaciones de cualquier persona, incluso de sus propios legisladores" (Ensayo, pg.113).

(179) "Cuando un ciudadano está falto de garantía social, entra en el derecho natural de defender él mismo todos sus derechos" (art.28 de la Declaración de Derechos propuesta por Robespierre).

(180) Las revoluciones son "la última salvaguardia de los pueblos", decía Tocqueville (EI Antiguo Régimen, pg.142); y también: "Creo que hay resistencias honradas y rebeliones legítimas. Lejos de mi decir, pues, de manera absoluta que los hombres de tiempos democráticos no deban nunca hacer revoluciones" (La democracia..., I-2-38, pg.381). "Resistir a la injusticia -decía lhering- es un deber del individuo para consigo mismo, porque es un precepto de la existencia moral; es un deber para con la sociedad, porque esa resistencia no puede ser coronada con el triunfo más que cuando es general (La lucha por el derecho, Doncel, Madrid, 1976, pgs.61-62).

(181) Caracterizaba Montesquieu a los Estados despóticos precisamente porque en ellos se impone una "obediencia sin límites"; en ellos no existe posibilidad alguna de resistencia: "El hombre es una criatura que obedece a otra que manda" (ob.cit., XIV-10, pg.68).

(182) Para Inglaterra, vid. Guizot, Historia, pgs.321-322.

(183) Choix, tomo I, pg.231

(184) Colección de leyes fundamentales, pgs.37 y 43

(185) En España la resistencia a la tropa justificaba la declaración de la "ley marcial" desaforando a los responsables y trasladando la competencia para juzgar de la causa a los tribunales militares. El sistema tuvo su origen en el número 8 de la Instrucción de 29 de junio de 1784 sobre bandolerismo.

(186) La lucha..., pg.61.

(187) Cfr. Olarieta Alberdi, "La autorización administrativa previa para procesar a los funcionarios públicos" ya citado, pgs.235 y stes.

(188) Estudios, pg.152.

(189) Ob.cit., pgs.28-29.

(190) Esta afirmación de Montesquieu ha levantado también olas de tinta, dando lugar a las más variadas interpretaciones. Para Duguit se trata de un fórmula sibilina (Traité, tomo II, pg.665), aunque lo más frecuente es leer que se trata de un misterio, de un enigma (así, Carl Schmitt: Teoría de la constitución, Alianza, Madrid, 1982, pg.188, aunque rectifica en La defensa de la constitución, pg.168). Montesquieu hace esa afirmación por tres razones: primera, porque la competencia del poder judicial se reduce a la resolución de litigios de Derecho privado, careciendo de la facultad de adoptar decisiones políticas; segunda, porque orgánicamente los jueces deben ser elegidos para desempeñar sus funciones temporalmente, evitando así la formación de corporaciones burocráticas; y tercera, porque como acabamos de decir, el poder judicial es un mero poder ejecutivo, carente de voluntad propia distinta de la de la ley que debe aplicar, porque no es independiente, porque no es representativo, porque no encarna a ninguna clase social, a ninguna "potencia". Es esto lo que permite a Montesquieu reducir los tres poderes a las dos "potencias", saltar del plano jurídico al político: el poder judicial es "en cierto modo" nulo; es nulo políticamente, no jurídicamente.

(191) El federalista, pgs.331 y 333

(192) Traité, tomo II, pg.669

(193) Rousseau, Del contrato social II-1, pg.32; en contra, exponiendo el carácter contradictorio de soberanía y separación de poderes son clásicas las expresiones de Duguit: "La Asamblea de 1789 quiso hacer una teoría de la soberanía y de la representación dividida de esta 
soberanía... La Asamblea nacional vio en la separación de poderes una división de la soberanía en diversos elementos, soberanía que permanece una e indivisible pese a la existencia de diversos elementos que la constituyen, cada uno de esos elementos delegado por representación a un órgano distinto que lógicamente será independiente y soberano en la esfera de soberanía que se le atribuye por representación" (Traité, tomo II, pg.668); en términos equivalentes: Jellinek, Teoría general, pg.376, Carlos de Cabo, ob.cit., pg.33, Sánchez Agesta, Historia, pgs.91-92. Lo que no es compatible con la soberanía es el sistema de gobierno mixto, no la separación de poderes. En la confusión del principio constitucional con la forma de gobierno, muchos autores imputan a aquel circuntancias que sólo aparecen en ésta que, por otro lado, es de origen pre-liberal.

(194) "De la soberanía del pueblo y sus límites", Cours, tomo I, pgs.173 y stes.

(195) Cours, tomo I, pg.189

(196) Filosofía del Derecho, pg.360

(197) Del contrato social, III-1 y 6, pgs.66 y 76.

(198) Metafísica de las costumbres, pg.143; también Hegel aproximó la ley a la voluntad, a la que calificaba de sede y punto de partida (Filosofía del Derecho, pg.65). La voluntad es, por tanto, el punto de partida no sólo para la comprensión del Estado sino también del Derecho, según una corriente jurídica de gran raigambre (v.gr. A.Posada: Teorías políticas, Madrid, 1905, pgs.89 a 114; R.Stammler: Tratado de Filosofía del Derecho, Ed. Nacional, México, 1980, pgs.73 a 87; y H.Kelsen, Teoría general, pgs.36 a 40).

(199) Vallet de Goytisolo, ob.cit., pgs.361 y stes. Hay que tener en cuenta que este animado debate en Inglaterra no se debe a otra razón que a la inexistencia allí de separación de poderes, principio que no se introdujo nunca en la formulación revolucionaria originaria tal y como se produjo en el continente (J.Chastenet: El Parlamento de Inglaterra, Argos, Buenos Aires, 1947, pg.40; García Pelayo, Derecho Constitucional Comparado, pg.283).

(200) "Otra causa, aún más secreta, provocaba y agravaba la explosión. No eran sólo los partidos políticos y religiosos los que se habían lanzado al combate; tras de ellos se ocultaba otra cuestión social: lucha de las clases diversas por alcanzar influencias y poder. No por eso se entienda que esas clases en Inglaterra estuviesen profundamente separadas y poseídas de mucho aborrecimiento como en otros países. El pueblo inglés no había echado en olvido que la alta nobleza había defendido las libertades populares al defender las suyas propias. Los propietarios rurales y los de las grandes poblaciones ocupaban desde hacía tres siglos los escaños del Parlamento en nombre de las municipalidades de Inglaterra. Pero durante el último siglo habían ocurrido grandes cambios en la fuerza relativa a las diversas clases en el seno de la sociedad, sin que por eso se hubiesen verificado cambios análogos en el Gobierno... La alta aristocracia ya no poseía ni daba, por consiguiente, a la monarquía la misma preponderancia en la nación. Los hidalgos de provincia, los arrendadores y pequeños propietarios rurales, que entonces eran muy numerosos, tampoco ejercían en los asuntos públicos una influencia proporcionada a su importancia en el país: habían crecido pero no se habían elevado" (Guizot, Historia, pg.325).

(201) Bobbio, La teoría de las formas de gobierno, pgs.104 a 106.

(202) En cuanto al equilibrio de poderes -dirá Robespierre- nosotros hemos sido los engañados por ese prestigio, en un tiempo en que la moda parecía exigir de nosotros ese homenaje a nuestros vecinos, en un tiempo en que el exceso de nuestra propia degradación nos permitía admirar las instituciones extranjeras que ofrecían alguna débil imagen de la libertad. Pero por poco que reflexionemos nos daremos cuenta fácilmente de que ese equilibrio no es sino una quimera o azote, que supondría la nulidad absoluta del gobierno, si no llevase directamente a una coalición de intereses contra el pueblo. Así Inglaterra, donde el oro y el poder del monarca inclinan constantemente la balanza del mismo lado; donde el partido de la oposición lo solicita de vez en cuando la reforma de la representación nacional, para alejarla aún más de acuerdo con la mayoría a la que simula combatir; especie de gobierno monstruoso, donde las virtudes públicas no son sino una escandalosa parada, donde el fantasma de la libertad elimina la propia libertad, donde la ley consagra el despotismo, donde los derechos del pueblo son el 
objeto de un tráfico confeso, donde la corrupción no tiene ni el freno del pudor. ¿Qué nos importan las combinaciones que equilibran la autoridad de los tiranos? Lo que debemos extirpar es la tiranía. No es en las querellas de sus amos donde los pueblos han de buscar la tranquilidad de respirar unos instantes. En su propia fuerza han de situar la garantía de sus derechos (El discurso jacobino..., pgs.74-75).

(203) Loewenstein, ob.cit., pgs.43-44.

(204) Para Paine la clasificación de las formas de gobierno era entre las electivas y de representación, por una parte, y las de sucesión hereditaria, por la otra: "En cuanto a esa cosa equívoca llamada gobierno mixto -añadía- como el último gobierno de Holanda y el presente gobierno de Inglaterra, no constituye una excepción a la regla general, ya que sus partes consideradas separadamente, o son representativas o son hereditarias" ("Disertación sobre los primeros principios del gobierno", en El sentido común y otros escritos, Tecnos, Madrid, 1990, pg.72).

(205) En los Estados Generales se denominaba "voto nacional" a la resolución unánime del Tercer Estado (Soboul, Compendio, pg.95).

(206) Art.8-II-III de la Constitución de 1791. Según Montesquieu la monarquía se diferencia del "gobierno popular" porque en aquella el rey no está sometido a la ley, sino por encima de ella, mientras que en el otro "debe soportar todo su peso" (ob.cit., III-3, pg.63).

(207) ¿Qué es el tercer estado?, pg.13

(208) El sentido común, pg.11

(209) Cours, tomo I, pg.14

(210) Qué es el tercer estado?, pg.64; y más adelante añade: "Se dice en Inglaterra que la Cámara de los Comunes representa a la nación. No es exacto. Creo que ya lo he hecho observar; en tal caso, repito que si los comunes solos representaran a toda la voluntad nacional, formarían solos todo el cuerpo legislativo. Habiendo decidido la constitución que ellos no eran sino una parte de tres, es menester que el rey y los lores sean considerados como representantes de la nación" (pg.84). Esa era exactamente la contradicción: representantes de la nación no elegidos por la nación.

(211) Curso, tomo II, pg.27; pero no hay mística alguna: la diferencia radica en que en Francia hubo revolución, incluso en los principios, especialmente por las ideas de soberanía "nacional" y representación, que en Inglaterra se soslayaron con componendas prestadas de la Biblia. Los>la Biblia. Los autores más revolucionarios (Rousseau, Condorcet, Paine) se opusieron al bicameralismo y al veto, aduciendo que con la división de poderes de las constituciones mixtas, se perpetuaba la división de clases sociales, preconizando en su lugar la disolución de todas las diferencias en una categoría uniforme de ciudadano.

Todo partió de la negativa de la Iglesia anglicana a reconocer el peligroso derecho de resistencia, a admitir un cambio de legitimidad, y esto y la soberanía son equivalentes. Lejos de admitir el derecho de resistencia, sus prédicas llamaban a la no resistencia (G.M.Trevelyan: La revolución inglesa (1688-1689), Fondo de Cultura Económica, México, 1986, pgs.108 y stes.). Según Blackstone el veto no deriva de la constitución ni del pacto social, sino de la tradición, mientras que en Lally-Tollendal el veto es una norma de derecho positivo (Choix, tomo I, pgs.257-258).

La mística, pues, no estaba en Francia sino en Inglaterra precisamente: "Decir que la constitución de Inglaterra es una unión de tres poderes que recíprocamente se contrarrestan es ridículo", afirmó Paine (El sentido común, pg.9). También Kelsen destacó que separación de poderes y democracia son principios no asimilables (Teoría general, pg.335), que caben constituciones con separación de poderes anti-democráticas, cuyo prototipo son, en el sentido kelseniano, las mixtas, pues democracia exige que todo el poder se concentre en el pueblo y que se ejercite por un cuerpo electo y responsable ante la Constitución inglesa no respondía a este esquema. Vid. Sánchez Agesta, Curso, pgs.103 y stes. 
(212) "Es imposible concebir la idea de dos soberanías, una soberanía para querer y otra soberanía para actuar" (Paine, El sentido común, pg.94).

(213) Cfr. Joaquín Varela, La teoría del Estado..., pgs.71 y stes.

(214) Chastenet, ob.cit., pg.26; más extensamente en W.Stubbs, ob.cit., tomo II, pgs.622 y stes.

(215) Colección de leyes fundamentales, pgs.40, 41 y 42.

(216) Filosofía del Derecho, pg.389.

(217) El federalista, pgs.211 y 222.

(218) Ob.cit., tomo II, pg.12.

(219) A.Soboul: La revolución francesa, Orbis, Barcelona, 1987, pgs. 66 y stes.

(220) Exceptuamos a Hamilton que utiliza en ocasiones la expresión "constitución limitada", que él mismo define de la forma siguiente: "Por Constitución limitada entiendo la que contiene ciertas prohibiciones expresas aplicables a la autoridad legislativa, como, por ejemplo, la de no dictar decretos que impongan penas e incapacidades sin previo juicio, leyes 'ex post facto' $y$ otras semejantes. Las limitaciones de esta índole sólo pueden mantenerse en la práctica a través de los tribunales de justicia, cuyo deber ha de ser el declarar nulos todos los actos contrarios al sentido evidente de la Constitución" (El federalista, pg.331). Hamilton se refería, pues, a los límites del legislativo como poder supremo, a la preferencia por una constitción mixta, a la necesidad de proceder a un reparto material de competencias y, más específicamente, al control de constitucionalidad de las leyes por el Tribunal Supremo.

(221) Por ejemplo, Calzada Conde, ob.cit., pgs.145-146; y en referencia a los derechos individuales, habla la autora de autolimitación (pg.154); vid. también García Pelayo, Derecho Constitucional Comparado, pg.57 y Las transformaciones..., pg.57.

(222) Jellinek también habló de la indivisibilidad del poder del Estado (Teoría general, pgs.373 y stes.) y dijo que la teoría de la separación de poderes confundía el poder del Estado con la soberanía, entendiendo el primero en un sentido material y éste formal. El pensamiento de Jellinek está muy alejado de los clásicos liberales e imputa -y critica- en el constitucionalismo originario determinados componentes que no le son propios. Ahora bien, su distinción entre poder del Estado -entendido materialmente- y soberanía -elemento formal- tiene resonancias liberales y no está muy alejado de lo que he llamado reparto material y formal de competencias. Su idea de la indivisibilidad del poder del Estado también es común con los clásicos, si bien se integra en una cosmovisión ideológico-política distinta.

(223) Ob.cit., III-10, pg.69.

(224) Del contrato social, III-2, pgs.67 y 68.

(225) Duguit, Traité, tomo II, pgs.661-662; Carré de Malberg, ob.cit., tomo II, pg.20; Pérez Serrano, Tratado, pg.374; Tomás y Valiente, Códigos y constituciones, pg.126.

(226) Loewenstein ha calificado de "mecanicista" (ob.cit., pg.54) al principio de separación de poderes. En realidad, creemos que se ha hecho y se sigue haciendo -entre otros, el propio Loewenstein- una interpretación mecanicista de la separación de poderes. Para el pensamiento burgués revolucionario, la garantía de la libertad civil era la ley, el poder legislativo. Vid. por ejemplo, los arts.39 y stes. de la Constitución de Bayona; también Kant, Metafísica de las costumbres, pg.151; y Guizot, Historia, pg.323.

(227) Choix, tomo I, pg.256.

(228) Del contrato social, III-15, pg.99

(229) El federalista, pg.298. 
(230) Ob.cit., XI-6, pg.154.

(231) No significa el "référé legislatif" que los jueces no pudieran interpretar la ley, sino todo lo contrario. Podían hacerlo pero su interpretación coexistía con la del legislativo, y ésta era de orden superior. La Constitución belga de 1830 decía que "la interpretación de las leyes por vía de autoridad pertenece solamente al poder legislativo" (art.28), dejando abierta la posibilidad de interpretaciones judiciales.

(232) Así lo pusieron de manifiesto en España los partidarios de la "jurisdicción retenida" en el debate sobre el proyecto de ley de la jurisdicción contencioso-administrativa de 1888: existía "el riesgo evidente de establecer frente el Poder ejecutivo, cuyos verdaderos jefes son los ministros, otro poder cuyos representantes revisen y examinen dentro de la misma órbita, pero con medios y atribuciones independientes, las actas y resoluciones de aquellos" (Luis Martín Rebollo: El proceso de elaboración de la Ley de lo contencioso-administrativo de 13 de setiembre de 1888, Instituto de Estudios Administrativos, Madrid, 1975, pg.102). En parecidos términos, Mellado escribió que si se encomendara lo contencioso-administrativo a los tribunales ordinarios "se atentaría contra la independencia y la libertad de la Administración, y se subordinaría esta última a los primeros, dándose así al Poder moderador, en quien reside el poder administrativo, un superior que juzgase sus actos o los de sus agentes, con mengua de su prestigio" (Tratado elemental de Derecho Administrativo, Madrid, 1894, pg.131).

(233) Leviatan, II.29; y también: "Se dice: los dos brazos de un Estado son la fuerza y la justicia, el primer de los cuales reside en el rey, mientras que el otro está depositado en manos del Parlamento. Como si un Estado pudiera subsistir cuando la fuerza está en manos de alguno a quien la justicia no tenga autoridad para mandar y gobernar" (idem, II-26-6).

(234) Ensayo, pg.112.

(235) Sur le gouvernement de Pologne, pg.188.

(236) Choix, tomo III, pgs.256-257.

(237) Idem, tomo III, pg.406.

(238) Colección de leyes fundamentales, pg.52

(239) A los efectos que aquí interesan es irrelevante la distinción entre gobierno, administración y ejecución; para cuando sea imprescindible diferenciar, tendremos en cuenta el criterio de Maurice Hauriou, para quien "la función gubernamental consiste en solucionar, a compás de los sucesos, los asuntos excepcionales que afectan a la unidad política y a los grandes intereses nacionales; la función administrativa consiste en gestionar los asuntos públicos ordinarios" (Principios, pg.373); también Villar Palasí, ob.cit., pg.50.

(240) Tratado de Derecho Administrativo, Instituto de Estudios Políticos, Madrid, 1971, tomo I, pg.37; también con otros autores: La Administración en la Constitución, Centro de Estudios Constitucionales, Madrid, 1980, pg.12; sobre las corrientes jurídico-doctrinales que han apoyado esta tesis, vid. Villar Palasí, ob.cit., pgs.48 y stes. En contra, refiriéndose concretamente a la Constitución de Cádiz, Blanco Valdés, ob.cit., pg.140. En aquella primera Constitución, en efecto, lo que se pretende es un reparto exhaustivo de competencias entre ambos poderes: "Las facultades de las Cortes se han expresado con individualidad para que en ningún caso pueda haber ocasión de disputa o competencia entre la autoridad de las Cortes y la del Rey" (Colección de leyes fundamentales, pg.44). Pero el art.170 contiene una clausula residual o habilitación general a favor del rey, extendiendo su autoridad "a todo cuanto conduce a la conservación del orden público en lo interior, y a la seguridad del Estado en lo exterior", lo que ponía al rey al mismo nivel que las Cortes (vid. D.Sevilla Andrés: Historia política de España 1808-1968, Ed.Nacional, 1969, pgs.38-39.

(241) "Concepto de participación política", en Capital monopolista y sociedad autoritaria, pgs.46-47.

(242) V.gr. el art.46 del Real Decreto de orden público de 20 de marzo de 1867 decía que bajo el estado de guerra el capitán general del distrito militar "reasumía" todos los poderes. 
(243) Pérez Serrano, Tratado, pg.371.

(244) Cuando Locke escribe su obra, el mercantilismo está en pleno auge en Inglaterra, vid. Pierre Deyon: Los orígenes de la Europa moderna: el mercantilismo, Península, Barcelona, 1970, pgs.39 y stes.

(245) Montesquieu escribe su obra más de medio siglo después de Locke, cuando el mercantilismo ha sido abandonado y Delamare ya ha publicado su trabajo, imponiéndose la "cameralística" y su concepto de "Estado policía". Al tiempo que Montesquieu escriben también Hume (1752), Cantillon (1755) y Adam Smith que, pese a redactar su obra cumbre varias décadas después, impartió un curso en 1750-1751 abogando por la libertad de comercio. En su Investigación argumentaba Adam Smith las razones de su toma de posición: "El monopolio ha incrementado de tal forma el número de los obreros fabriles que, a la manera de un ejército poderoso, han llegado a ser una amenaza para el Gobierno, y en muchas ocasiones hasta intimidaron al legislador" (Investigación sobre la naturaleza y causas de la riqueza de las naciones, Fondo Cultura Económica, México, 1958, pg.416).

(246) En defensa..., pg.53.

(247) La dictadura, pg.73.

(248) C.J.Friedrich: La Filosofía del Derecho, Fondo de Cultura Económica, México, 1969, pgs. 123 y stes.

(249) Ensayo, pg.124; Rousseau admitió esta misma posibilidad, y la llamó "dictadura" (Del contrato social, VI-4).

(250) Ensayo, pg.21.

(251) Hauriou subrayó, por una parte, la correspondencia entre discrecionalidad y oportunidad, es decir, su conexión con las materias sujetas a decisión puramente política (Principios, pgs.351 y 356) y, por el otro, reconoció su antagonismo con lo contencioso: sobre lo discrecional y lo político no cabe mediación jurisdiccional (Ibid, pg.368).

(252) "Esta caracterización de la ciencia de la Policía como ciencia de hechos, produce que lo que cada autor persiga y exponga no sean principios de legalidad, sino principios de oportunidad. Así pues, la segunda característica, que es una consecuencia de la primera, es la caracterización de la ciencia de la Policía como ciencia de la oportunidad" (Villar Palasí, ob.cit., pg.194).

(253) "El gobierno es la gerencia de los asuntos de nación" (Paine, Los derechos del hombre, pg.110). Sieyes hablaba de "gobierno por procuración" (¿Qué es el tercer estado?, pgs.72-73). El art.4 de la Declaración de Derechos de Pennsylvania manifestaba "que todo el poder es originariamente inherente al pueblo y, en consecuencia, deriva de él; por lo tanto, todos los altos cargos del gobierno, ya sea legislativo o ejecutivo, son fiduciarios y están a su servicio, y en todo momento son responsables ante ellos". Vid. García de Enterría y T.R.Fernández, Curso, tomo I, pgs.423-424.

(254) "Todo poder que se ejerce sobre la nación ha de tener algún principio; ha de ser o delegado o asumido. No existen otras fuentes. Todo poder delegado es confianza; todo poder asumido es usurpación".Y también: "El gobierno no es una industria que cualquier individuo o corporación tenga derecho a implantar y ejercer en su propio provecho, sino únicamente un fideicomiso por derecho de aquellos que otorga la confianza y pueden retirarla en cualquier momento. Por sí mismo no tiene derechos, todo son obligaciones" (Paine, Los derechos del hombre, pgs.148 y 151); la idea de poder fiduciario implica el derecho de resistencia (Troper, ob.cit., pg.140) y, por tanto, la revocabilidad por el comitente, idea que a su vez conecta con la de soberanía y por tanto con la de legitimidad, mientras que en los poderes delegados lo que subyace es el principio de legalidad.

(255) Sobre la contradicción entre prerrogativa y constitución desde una perspectiva histórica en Inglaterra, cfr. W.Stubbs, ob.cit., tomo II, pgs.619 y stes. 
(256) Ensayo, pg.126; los "bill of indemnity" son un claro ejemplo: el ejecutivo tomaba la iniciativa para sofocar los motines e insurrecciones sin sujetarse a leyes ni formalidades, y luego el parlamento exoneraba a las tropas de las responsabilidades en que hubieran podido incurrir.

(257) Villar Palasí (ob.cit., pg.50) y Garrido Falla (Tratado, tomo I, pg.53) han expuesto que "la función política o de Gobierno se refiere a un momento de la actividad estatal anterior a la división o encasillamiento de la misma en poderes". Es algo característico de todas las constituciones monárquicas de soberanía mixta: "La declaración de guerra -leemos en referencia a las Cortes de Cádiz- es nominada no como una facultad, designación literal de la propia Constitución, sino como una prerrogativa, lo cual parece querer indicar que aquella debía corresponder al Rey en su calidad de tal, en tanto que atribución esencial de su estatus particular o, por decirlo de otro modo, en su calidad de poder anterior a la propia Constitución, forma de razonar ésta que estará siempre presente -bien de forma expresa o bien, como en el caso, sobreentendida- en el discurso ideológico de los diputados realistas cuando se trate de defender los poderes centrales del Monarca" (Blanco Valdés, ob.cit., pg.158).

(258) "El pueblo que detenta el poder soberano puede hacer por sí mismo todo aquello que pueda hacer bien; lo que no pueda hacer bien lo hará por medio de sus ministros" (ob.cit., II-2, pg.56).

(259) Doctrina que es el antecedente inmediato de las tesis de Maurice Hauriou, para quien el poder ejecutivo no sólo no emana de la nación, sino que "ha contribuído poderosamente a formar la nación misma y el Estado" (Principios, pg.256).

(260) Los arts.145 y 171 de la Constitución de 1812 emplean precisamente la palabra prerrogativa para aludir a la sanción de las leyes, pero no al enumerar las demás facultades regias, ni el art.170; hay, pues, una diferencia implícita entre prerrogativa y mera facultad constitucional.

(261) El carácter sagrado se aplicó también a la propiedad privada, por ejemplo, en el art.4 del Decreto de abolición de los señoríos jurisdiccionales. Vid. "Los principios de la constitución...", pg.169.

(262) E.L.Woodward: Historia de Inglaterra, Alianza, Madrid, 1988, pg.117; y Figgis, ob.cit.

(263) Pasamos por alto aquí la distinción entre irresponsabilidad, que es un principio político equivalente a irrevocabilidad, e inmunidad $o$ inviolabilidad, que es una exención de responsabilidad criminal; vid. E.Gordon, ob.cit., pg.47; F.León y Castillo: "Irresponsabilidad del poder real y responsabilidad de los ministros", en Academia de Ciencias Morales y Políticas, Madrid, 1901; F.Perrin: De la responsabilité penal du Chef de l'Etat et des ministres, Paris, 1900; Duguit, Traité, tomo IV, pgs.806 y stes.; L.Jiménez de Asúa: Tratado de Derecho Penal, Losada, Buenos Aires, 1950, tomo II, pgs.1312 y stes.

(264) Vid. Ernst H.Kantorowicz: Los dos cuerpos del rey. Un estudio de teología medieval, Alianza, Madrid, 1985, pgs.350 a 359, y B. Clavero: Tantas personas como Estados. Por una antropología política de la historia europea, Tecnos, Madrid, 1986, pgs.53 a 84.

(265) Son demostración de la falta de independencia del Derecho público respecto al privado, en el sentido de Hauriou (Précis, pg.334). Al respecto, véase Sebastián Martín-Retortillo: El Derecho Civil en la génesis del Derecho Administrativo y de sus instituciones, Sevilla, 1960; y A.J.Porras Nadales: Introducción a la teoría del Estado postsocial, PPU, Barcelona, 1988, pgs.21-22.

(266) "Las leyes de la religión son un precepto superior porque recaen sobre el príncipe igual que sobre los súbditos. Sin embargo, esto no ocurre en lo que se refiere al derecho natural ya que se supone que el príncipe no es un hombre" (Montesquieu, ob.cit., III-10, pg.69). EI carácter irracionalista de esta teoría ha sido puesta de relieve por Schmitt (La dictadura, pg.63).

(267) Según el art.1-IV-III de la Constitución francesa de 1791, "el rey es el jefe supremo de la administración general del reino". 
(268) Según el art.2-II-IV-III de la Constitución de 1791, "Ios administradores no tienen ningún carácter de representación", sino que se trata de agentes temporalmente elegidos por el pueblo para desempeñar sus funciones. Por contra, el rey no era un cargo elegido ni temporal.

(269) Ob.cit., pg.109; vid. también J.Laferrière: "Le contreseing ministeriel", en Revue General d'Administration, abril-mayo de 1908; J.Cáceres: El refrendo ministerial, Madrid, 1934. En este punto merece la pena consignar la opinión de Kelsen: "El hecho de que en una monarquía constitucional el jefe del poder ejecutivo no sea responsable ante el Parlamento, es un residuo de la monarquía absoluta y no "como podría estar inclinado a suponerlo" una aplicación del principio de separación, que en realidad atañe a la división de poderes" (Teoría general, pg.334).

(270) Vid. Mariana, ob.cit., pgs.310 y stes.

(271) La diferencia entre "ley" y "decreto" fue remarcada así por Rousseau: "Se ve incluso que por reunir la ley la universalidad de la voluntad y la del objeto, lo que un hombre, quien quiera que pueda ser, ordena por autoridad propia no es una ley; incluso lo que el soberano ordena sobre un objeto particular no es tampoco una ley, sino un decreto, ni un acto de soberanía, sino de magistratura" (Del contrato social, II-6).

(272) "Cuando las naciones se ocupen en la gran labor de hacer sus constituciones -expuso Paine- deberán examinar con el mayor cuidado la naturaleza y misión de ese poder llamado ejecutivo. Lo que sean los poderes legislativo y judicial, todo el mundo puede verlo; pero el llamado en Europa poder ejecutivo, para distinguirlo de los otros dos, o es políticamente innecesario, o se trata de un caos de cosas desconocidas". Y añade a continuación Paine: "Todo lo que se necesita es un departamento oficial al que se puedan dirigir, desde las distintas partes de la nación y desde el extranjero, los diversos informes para que sean expuestos ante los representantes nacionales; pero no hay razón para llamarlo ejecutivo; ni siquiera se le puede considerar por ningún concepto más que como inferior al legislativo. La autoridad soberana, en cualquier nación, reside en el derecho de dictar leyes, y todo lo demás son departamentos oficiales" (Los derechos del hombre, pgs.163-164); y también: "El gobierno no es necesario más que para suplir los pocos casos en que la sociedad y la civilización no son lo bastante competentes" (pg.132). Expresiones parecidas había escrito Locke: "El Estado es, a mi parecer, una sociedad de hombres constituída solamente para procurar, preservar y hacer avanzar sus propios intereses de índole civil" (Carta sobre la tolerancia, pg.8). Hauriou también constató cómo la separación de poderes redujo a la nada al poder ejecutivo; pero no tiene en cuenta el veto, la intervención del rey en el legislativo, que era el punto clave del primer constitucionalismo (Précis, pg.IX).

(273) L.Sánchez Agesta: La antítesis del desarrollo. Constitución, desarrollo y planificación, Instituto de Estudios Políticos, Madrid, 1976, pgs.37-38.

(274) Colección de leyes fundamentales, pg.64.

(275) "Queda uno asombrado por la sorprendente facilidad con que la Asamblea constituyente pudo destruir de un sólo golpe las antiguas provincias de Francia, varias de las cuales eran más antiguas que la monarquía, dividiendo metódicamente el reino en ochenta y tres partes distintas, como si se hubiera tratado del suelo virgen del Nuevo Mundo. Nada causó más sorpresa, e incluso espanto, al resto de Europa, que no estaba preparada para semejante espectáculo... Parecía, en efecto, como si se desgarraran cuerpos vivos, pero no se trataba más que de despedazar cadáveres" (Tocqueville: El Antiguo Régimen, pg.112). "Después de 1789 la revolución popular -escribe por su parte Soboul- tendía a la descentralización y a la autonomía. Tendencia lejana, profunda, comprimida durante largo tiempo por la imperiosa necesidad de un poder monárquico fuerte, y que en 1789 se liberó tanto en las ciudades como en el campo" (Principios ideológicos..., pg.196). No es extraño, por ello, que los conservadores, encabezados por Cazalès se opusieran a la descentralización (Choix, tomo III, pg.396).

(276) Norman Hampson: Historia social de la revolución francesa, Alianza, Madrid, 1970, pgs.109 y 153; G.Lefebvre, ob.cit., pg.56; en sentido opuesto, E.Laferrière: Traité de la jurisdiction administrative et des recours contentieux, Paris, 1887, tomo I, pg.151. 
(277) Francesç Nadal: Burgueses, burócratas y territorio, Instituto de Estudios de Administración Local, Madrid, 1987, pg.27.

(278) G.Lefebvre, ob.cit., pg.61.

(279) Singularmente en España, donde lejos de disponer de competencias para declarar la ley marcial, carecían los ayuntamientos de facultades de intervención sobre el orden público, ya que su función era, o bien preventiva (art.X-I) o, en el caso de tener que poner "remedio" (art.VI-I) debía advertir al gobernador civil. Cabe pensar que en el segundo caso, alusivo a los caminos, se refería el legislador gaditano implícitamente a la cuestión del bandolerismo, y no meramente a las obras públicas.

(280) García Fernández, ob.cit., pgs.38 y stes.; Sánchez Agesta, Historia, pgs.74-75; García de Enterría, La Administración española, Alianza, Madrid, 1972, pg.70.

(281) A pesar de que la guerra de la Independencia tuvo su origen en las Juntas locales, y que la vida local tuvo entonces una intensa vida propia; y a pesar, como expuso Adolfo Posada, del art.10 de la propia Constitución (Evolución legislativa del régimen local en España 1812-1909, Instituto de Estudios de Administración Local, Madrid, 1982, pg.69).

(282) García Fernández, ob.cit., pgs.286 stes.

(283) M.Fernández Almagro: Orígenes del régimen constitucional en España, Labor, Barcelona, 1976, pg.88.

(284) Filosofía del Derecho, pgs.281 y stes.

(285) Como ha apuntado García de Enterría, Legislación delegada..., pgs.91-92.

(286) García de Enterría, La Administración española, pgs.70 a 72; en contra, García Fernández, ob.cit., pg.44.

(287) Ob.cit., pg.119.

(288) La afirmación de Agúndez de que lo contencioso-administrativo, que "atenta contra la separación de poderes", aparece desde un principio como competencia de la propia Administración (ob.cit., pg.106), además de única carece de todo fundamento.

(289) Que se manifiesta también en la sutil distinción entre señoríos territoriales y jurisdiccionales.

(290) E.Laferrière, Traité, tomo I, pgs.158 y stes.

(291) Précis, Libro II, Título I, Capítulo 1, Sección 1; citamos de la 12 edición, impresa en 1933, pg.335, donde la referencia de Hauriou al artículo 13, además de incompleta es errónea.

(292) Sí se refería, por contra, aquel artículo a lo que podría considerarse como un antecedente de la autorización administrativa previa para procesar a los funcionarios públicos, cuestión extraña -aunque conexa- a la que aquí tratamos.

(293) Vid. J.R.Parada Vázquez: "Privilegio de decisión ejecutoria y proceso contencioso", Revista de Administración Pública, núm 55, enero-abril de 1968, pg.67.

(294) Por ejemplo Carré de Malberg, ob.cit., tomo I, pg.808; en España, Santamaría Pastor, ob.cit., pgs.45 a 54, y más recientemente, Blanca Lozano: "Conflictos de jurisdicción entre la Administración y los tribunales: perspectiva histórica y nueva configuración", Revista de Administración Pública, núm. 118, 1989, pg.177.

(295) Ambas nociones estaban tan delimitadas en la época, que aún una disposición tan tardía como la Real Orden de 23 de marzo de 1833 apuntaba que "para evitar nuevas contestaciones sobre el límite de lo gubernativo y judicial, se entienda que para llamar un negocio contencioso ha de preceder demanda o denuncia formal, hasta cuyo acto habrá de considerarse como gubernativo". Puede consultarse esta Real Orden en C.Massa Sanguinetti: Diccionario jurídico- 
administrativo, Madrid, 1861, tomo III, pg.823. Como ha escrito Parada Vázquez, "la afirmación de que la Administración activa no tenía reconocido el privilegio de decisión ejecutoria en los orígenes del sistema contencioso, se fundamenta en que tal poder es un poder y una función judicial. Nos referimos, por supuesto, al poder de decidir controversias, situaciones de conflicto en forma ejecutoria" ("Privilegio de decisiónejecutoria...", pg.68).

(296) No resulta tampoco exacto, en consecuencia, que el objetivo del establecimiento del sistema contencioso-administrativo fuera, como afirma E.Laferrière, conseguir la "unidad política y administrativa del reino" (ob.cit., tomo I, pgs.151-152).

(297) No es tampoco consecuencia de la separación de poderes o un efecto de ella, como ha sostenido Parada Vázquez ("Privilegio de decisión ejecutoria..." pg.70), sino un mecanismo tan compatible con ella como con su opuesto. El autor que citamos llega a añadir poco más adelante: "Es en su versión llamada francesa o napoleónica cuando el principio de división de poderes provoca el efecto de una independencia y separación entre Tribunales y la Administración" (ibid., pg.73).

(298) Se ha calificado de "desconfianza", en general, hacia los jueces, la posición originaria del liberalismo, cuando se trataba de una desconfianza hacia el sistema judicial y los jueces absolutistas, no hacia su propio sistema judicial que, por su puesto, era radicalmente opuesto al preexistente. De aquí también la dependencia política del sistema judicial constitucional, cuya configuración está en función del sistema socio-económico y político de origen.

(299) Cfr.J.A.García Trevijano: Tratado de Derecho Administrativo, Madrid, 1964, tomo I, pgs.397 y stes.

(300) La influencia inglesa es perceptible en tratadistas tan tempranos como Jovellanos o Ramón de Salas, y se conoce el epistolario de Bentham con destacados liberales españoles. Vid. M.Moreno Alonso: "Sugerencias inglesas para unas Cortes españolas", en Materiales para el estudio de la Constitución española de 1812, pgs.499 a 520; Sevilla Andrés, ob.cit., pg.6; J.M.Jover Zamora, con Ubieto, Reglá y Seco: Historia de España, Barcelona, 1972, pg.531; Joaquín Varela, La teoría del Estado..., pgs.16 y stes.; ha insistido en ella Santamaría Pastor, ob.cit., pgs.31, 38, y 61-62.

(301) Vid. J.R.Parada Vázquez: Los orígenes del contrato administrativo en el Derecho español, Sevilla, 1970.

(302) Los principios de la Constitución..., pgs.200 y 208.

(303) Jiménez de Asúa, Tratado, tomo II, pg.165; L.Mosquera Medina: "La posición del Poder Judicial en la Constitución española de 1978", con Predieri, García de Enterría y otros: La Constitución española de 1978, Civitas, Madrid, 1981, pg.726; F.Ledesma Bartret: "Relaciones entre el Consejo General del Poder Judicial y del poder ejecutivo", Jornadas de Estudio sobre el Consejo General del Poder Judicial, Madrid, 1983, pg.496; Blanca Lozano, ob.cit., pg.186; Parada Vázquez: Los conflictos entre la Administración y los tribunales ante la nueva Constitución", Revista de Administración Pública, 1977, núm.84, pg.558; Olarieta Alberdi: "Injerencias político-administrativas en el proceso penal. Sistema histórico y evolución legislativa", Revista Vasca de Administración Pública, núm.22, 1988, pg.147.

(304) Alberto Gil Novales: Las sociedades patrióticas. Las libertades de expresión y de reunión en el origen de los partidos políticos, Tecnos, Madrid, 1975, tomo I, pg.XIV; Carlos Marichal ha calificado a los jueces de quinta columna del carlismo (La revolución liberal y los primeros partidos políticos en España 1834-1844, Cátedra, Madrid, 1980, pgs.155 y stes.); Blanco Valdés, ob.cit., pgs.300 y 492 y stes. También, J.Guasp: Comentarios a la Ley de Enjuiciamiento Civil, Madrid, 1945, tomo I, pg.456. Al respecto, son imprescindibles los análisis de Luis Moreno Pastor: Los orígenes del Tribunal Supremo, pgs.125 y 157, y para las depuraciones de jueces durante la etapa de Mendizábal: pgs.222 y stes. Santamaría Pastor ha mantenido una postura dual, defendiendo por una parte la fidelidad constitucional de los jueces en la fase doceañista (Sobre la génesis..., pgs.30, 82-83 y 127), pero exponiendo también que en el trienio los jueces eran los colocados por la primera reacción fernandina (pgs.63,64 en nota, y 68). 
(305) Como el del art.6 de la Constitución.

(306) Colección de leyes fundamentales, pg.66.

(307) J.M Cordero Torres: El Consejo de Estado: su trayectoria y perspectivas en España, Instituto de Estudios Políticos, Madrid, 1944, pg.81.

(308) Colección de leyes fundamentales, pg.48.

(309) No podemos dejar de citar, además, el art.14, que es el inverso del art.13 de la ley francesa de organización judicial: "Los intendentes no ejercerán funciones judiciales ni conocerán de los negocios contenciosos de Hacienda". La obligación de no injerencia sujetaba a ambos poderes, no solamente al judicial.

(310) Ob.cit., pgs.85 y stes.

(311) Ob.cit., pg.188.

(312) Así García de Enterría y T.R.Fernández: Curso, tomo II, pg.48; y Garrido Falla: "La evolución del recurso contencioso-administrativo en España", Revista de Administración Pública, núm. 50, 1966, pg.15.

(313) Escritos y discursos, pgs.95-96.

(314) Sieyes, Ensayo sobre los privilegios, pg.51; Pedraz Penalva, Formación, pgs.78 y stes. La concepción tradicional ha sido expuesta contradictoriamente por Jellinek: "El individuo en tanto en cuanto es persona sólo está sometido a un poder limitado. La subordinación del individuo al Estado se extiende hasta donde el Derecho ordena, pues toda exigencia del Estado respecto del individuo necesita estar fundada jurídicamente. La esfera de libertad del individuo la constituye aquello que resta para él, abstracción hecha de las limitaciones jurídicas que le son impuestas. Esta libertad no sólo lo es de hecho, sino que a causa de la limitación del poder del Estado y del reconocimiento de la personalidad, tiene también un carácter jurídico" (Teoría General, pg.314).

(315) Colección de leyes fundamentales, pg.49

(316) Ob.cit., XI-6, pg.153

(317) Choix, tomo I, pg.384

(318) Ibid, tomo III, pg.229

(319) Sobre los Parlamentos franceses, vid. C.Dareste de Chavanne: Histoire de l'Administration en France et des progrès du pouvoir royale, Paris, 1848, tomo I, pgs.258 y stes.; y A.Esmein: Histoire de la procedure criminelle en France, Frankfurt am Mein, 1969, pgs.264 y stes; y Calamandrei, "La cassazione...", tomo I, pgs.264 y stes.

(320) Art.21 de la ley de diciembre de 1790 sobre el Tribunal de Casación, y art.21 Título III Capítulo V de la Constitución de 1791.

(321) V.gr. Pedraz Penalva, Formación,pg.96; y “La jurisdicción...”, pg.930; y L.Mosquera Medina: "La posición del poder judicial en la Constitución de 1978", con García de Enterría, A.Predieri y otros: La Constitución española de 1978, ya citada, pg.721.

(322) "Este procedimiento de consulta para resolución de las 'dudas de ley' -escribe Moreno Pastor- demuestra claramente que en la facultad de aplicar las leyes en los juicios civiles y criminales juzgando y haciendo ejecutar lo juzgado -facultad que expresamente se confirió siempre a los Jueces y Tribunales por las Constituciones sucesivas- no iba incluída atribución para 'declarar la ley', resolviendo con carácter general sobre sus puntos dudosos, porque esta misión enlazaba con la propiamente legislativa y se atribuía al Rey y a las Cortes... Ni la nomofiliaquia de la ley (material) ni su uniforme aplicación o entendimiento general, son funciones que se atribuyan ni a los Tribunales de Justicia en general ni al Tribunal Supremo en particular" (Ob.cit., pgs.282 a 284). 
(323) La cassazione..., tomo I, pg.439

(324) Actas de la Comisión de Constitución, pgs.179-180.

(325) Principios, pg.346

(326) "Toda sociedad debe estar regulada por leyes y sometida a un orden común. Si haceis excepciones, al menos deben ser raras; y en ningún caso pueden tener sobre la cosa pública el mismo peso, la misma influencia que la regla común" (Sieyes, ¿Qué es el tercer estado?, pg.41)

(327) Felipe Clemente de Diego: "El artículo 6 del Código Civil español" y "La función jurisdiccional de los jueces y la aplicación del Derecho en general", Revista de Derecho Privado, núms.1 y 3,1913 , en especial pg.10.

(328) Ob.cit., XI-6, pg.156.

(329) Ibid, XI-6, pg.156

(330) Es significativo que Adam Smith al estudiar el sector publico de la economía ponga en primer lugar los gastos de defensa, y en el segundo los de justicia, por encima de todos los demás (Investigación..., pgs.614 y stes.)

(331) Hegel encuadra su análisis del sistema judicial dentro del apartado relativo a la sociedad civil, y no dentro del Estado ( Filosofía del Derecho, pg.281 y stes.).

(332) Del espíritu de las leyes, XI-6, pg.152.

(333) Considerations sur le gouvernement de Pologne, pg.215.

(334) Choix, tomo I, pg.380

(335) La trascendencia del jurado en los bocetos que la burguesía revolucionaria perfiló es extraordinaria, porque era una forma de apartar a los magistrados profesionales ligados al Antiguo Régimen. Sieyes le dio más importancia al jurado que a la Constitución inglesa (¿Qué es el tercer estado?, pg.66); en cambio la tibieza del art. 307 de la Constitución gaditana es palpable y se ciñe a la materia penal.

(336) Choix, tomo III, pgs.246-247; Soboul, Principios ideológicos, pg.65.

(337) Ibid, tomo III, pg.228

(338) Los seis libros de la República, III-2, pgs.219 a 223, y IV-4, pgs.282 a 282.

(339) Del espíritu de las leyes, II-3, pg.60.

(340) Jacques Chastenet, ob.cit., pgs.39-40; François Guizot, ob.cit., pgs.87 y 197; y Friedrich, ob.cit., pgs. 107-108 y 119.

(341) Trevelyan, ob.cit., pgs.18 y 19.

(342) Woodward, ob.cit, pgs.122-123; para la época de Cromwell, pg.136; Chastenet, ob.cit., pg.38; Guizot, ob.cit., pgs.57, 90 y 101; Lucas Verdú: La lucha por el Estado de Derecho, Bolonia, 1975, pg.27.

(343) Carl Schmitt, La dictadura, pg.83

(344) Destacamos este rasgo singular sin perjuicio de dejar constancia también de otros factores. Primero de la débil centralización: el nombre de "comunes" significaba precisamente que eran las comunidades locales autoorganizadas las que llevaban allí sus representantes (Strathearn Gordon: El Parlamento británico, Londres, 1848, pg.22). Y segundo, de la peculiar vida económica de la nobleza, mucho más dependiente de un capitalismo rudimentario que la francesa. "La Inglaterra del siglo XVII ya es una nación completamente moderna... No era tanto 
su parlamento, su libertad, su publicidad, su jurado, lo que hacía ya entonces a Inglaterra tan distinta del resto de Europa cuando algo más peculiar todavía y mucho más eficaz. Inglaterra era el único país donde se había no ya alterado sino eficazmente destruido el sistema de castas. Los nobles y los plebeyos se dedicaban juntamente a los mismos negocios, abrazaban las mismas profesiones y, lo qu esmucho más significativo, se casaban entre sí. La hija del más elevado señor podía casarse sin ninguna vergüenza con un hombre surgido de la nada" (Tocqueville: El Antiguo Régimen, pgs.45, 122 y 138). En cuanto a esto mismo, escribió también Marx: "El Inglaterra la servidumbre había desaparecido ya, de hecho, en los últimos años del siglo XIV. En esta época, y más todavía en el transcurso del siglo XV, la inmensa mayoría de la población se componía de campesinos libres, dueños de la tierra que trabajaban la tierra, cualquiera que fuese la etiqueta feudal bajo la que ocultasen la propiedad" (El capital, tomo I, pg.610). Esa fusión de la burguesía y la nobleza rural, a la que se llamó "gentry" permitió oponer un frente unido a las pretensiones absolutistas de la Corona (R.Kühnl, ob.cit., pgs.33 y 34).

(345) Paine, Los derechos del hombre, pg.155.

(346) "El completo colapso del poder real en un condado tras otro, cuando desembarcó Guillermo, se debió al hecho de que Jacobo no tenía una magistratura local efectiva a su servicio. Si hubiera tenido una burocracia pagada por él en los condados, como el rey de Francia en sus provincias, quizá hubiera salido bien del trance;pero dependía de una burocracia no pagada, compuesta de campesinos independientes... En cierto sentido, pues, la Revolución fuel el alzamiento de la magistratura local contra el poder central... Pero fue una desdicha que la indpendencia de los magistrados locales fuera aumentada por los sucesos de 1688-1689 -como ciertamente lo fue-porque lo que Inglaterra necesitaba no era menos control central, sino más... El control central perdió aún más terreno. Durante el siglo XVIII las magistraturas locales, tanto en las ciudades como en los condados, hicieron las cosas demasiado a su gusto, sin ninguna restricción por parte del rey ni del Consejo Privado" (Trevelyan, ob.cit., pgs.65-66). Tocqueville dejó constancia de cómo en su época -es decir, hacia 1840- eran las "clases inferiores" las que reclamaban la centralización en Inglaterra, "mientras que las clases superiores se esfuerzan por contener a esa misma administración dentro de sus antiguos límites" (La democracia..., I-1-15, pgs.342 y 343). Vid. también Villar Palasí, ob.cit., pg.230.

(347) La revolución inglesa no alteró sustancialmente "el poder dictatorial del juez de paz, que era a un mismo tiempo funcionario de policía, juez e instancia de apelación, y mantenía a las clases trabajadoras en condiciones de rigurosa dependencia. La burguesía de las finanzas, que dominaba el sector urbano, no estaba interesada en un cambio radical, sino sólo en una distribución de poderes entre ella y la aristocracia, que tenía en sus manos la administración autónoma rural" (R.Kühnl, ob.cit., pg.78). Esa alianza continuó tras la revolución inglesa: "La 'glorius revolution' entregó el poder, al ocuparlo Guillermo III de Orange a los capitalistas y terratenientes elaboradores de plusvalía. Estos elementos consagraron la nueva era, entregándose en una escala gigantesca al saqueo de los terrenos de dominio público, que hasta entonces sólo se había practicado en proporciones muy modestas. Estos terrenos fueron regalados, vendidos a precios irrisorios o simplemente anexionados por otros terrenos de propiedad privada, sin molestarse en encubrir la usurpación bajo forma alguna. Y todo esto se llevó a cabo sin molestarse en cubrir ni la más mínima apariencia legal. Estos bienes del dominio público, apropiados de mod tan fraudulento, en unión de los bienes de que se despojó a la Iglesia -los que no habían sino usurpados ya por la revolución republicana- son la base de esos dominios principescos que hoy posee la oligarquía inglesa. Los capitalistas burgueses favorecieron esta operación, entre otras cosas, para convertir el suelo en un artículo puramente comercial, extender la zona de las grances explotaciones agrícolas, hacer que aumentase la afluencia a la ciudada de proletarios libres y necesitados del campo, etc. Además, la nueva aristocracia de la tierra era la aliada natural de la nueva bancocracia, de la alta finanza, que acababa de dejar el cascarón, y de los grandes manufactureros, atrincherados por aquel entonces detrás del proteccionismo aduanal" (Marx: El capital, tomo I, pgs.615-616); vid. Chastenet, ob.cit., pgs.36-37

(348) "Histoire...", tomo I, pg.137.

(349) Histoire de la revolution française, 13를 Ed., tomo II, Libro II, nota 5 
(350) Principios ideológicos, pg.117; Kühnl, ob.cit., pg.36.

(351) Calamandrei, La cassazione..., tomo I, pg.415

(352) El Antiguo Régimen, pg.57

(353) Choix, tomo I, pgs.394-395

(354) Choix, tomo II, pgs.374 y 377.

(355) Calamandrei, La cassazione..., tomo I, pg.423

(356) El debate al respecto en la comisión, en Diz-Lois, ob.cit., pgs. 174 y stes.

(357) Choix, tomo III, pg.251

(358) El Antiguo Régimen, pg.105; pero se refiere, lógicamente, a los comisarios del rey, no a los del "tercer estado".

(359) ¿Qué es el tercer estado?, pg.66; Pedraz Penalva, Formación, pgs.163 y stes.

(360) Colección de leyes fundamentales, pg.61

(361) "Aunque la potestad judicial es una parte del ejercicio de la soberanía delegada inmediatamente por la Constitución a los Tribunales, es necesario que el Rey como encargado de la ejecución de las leyes en todos los efectos, pueda velar sobre su observancia y aplicación... Y por eso sus ejecutorias y provisiones deben publicarse a nombre del Rey considerándole en este caso como el primer magistrado de la Nación" (Colección de leyes fundamentales, pg.54).

(362) "Los Tribunales colegiados y la perpetuidad de sus cargos, y la facultad que tienen estos de calificar por sí mismos el hecho sobre el que han de fallar, sujetan sin duda alguna a los que reclaman las leyes al duro trance de hallarse muchas veces a discreción del juez o Tribunal. La Comisión no entrará a examinar las razones en que se fundan los que apoyan e impugnan uno y otro sistema. Encargada por V.M. de arreglar un proyecto de Constitución para restablecer y mejorar la antigua ley fundamental de la Monarquía, se ha abstenido de introducir una alteración sustancial en el modo de administrar la justicia, convencida de que reformas de esta trascendencia han de ser el fruto de la meditación, del examen más prolijo y detenido, único medio de preparar la opinión pública para que reciba sin violencia las grandes innovaciones. Pero al mismo tiempo, la Comisión ha creído que la Constitución debía dejar abierta la puerta para que las Cortes sucesivas, aprovechándose de las experiencia del adelantamiento, que ha de ser consiguiente al progreso de las luces, puedan hacer las mejoras que estimen oportunas en el importantísimo punto de administrar justicia" (Colección de leyes fundamentales, pg.51).

(363) Colección de leyes fundamentales, pg.54. Al respecto, cfr. Moreno Pastor, Los orígenes del Tribunal Supremo, ya citado; y M.Lorente Sariñena: "División de poderes e interpretación de ley", en Materiales..., pgs.401 a 420.

(364) Es reseñable que la admisión de un recurso de nulidad por el Tribunal Supremo significara, casi automáticamente, un delito de prevaricación por parte del tribunal "a quo", que daba lugar a la correspondiente responsabilidad judicial. El recurso era, pues, una vía indirecta de depuración de cargos judiciales. El Discurso Preliminar afirma que el "juicio de responsabilidad" contra jueces y magistrados es la consecuencia de la admisión del recurso de nulidad (Colección de leyes fundamentales, pg.54). El art.254 de la Constitución decía: "Toda falta de observancia de las leyes que arreglan el proceso en lo civil y en lo criminal, hace responsables personalmente a los jueces que la cometieren". Y el art.262 añadía: "Declarada la nulidad, la Audiencia que ha conocido de ella, dará cuenta, con el testimonio que contenga los insertos convenientes, al Supremo Tribunal de Justicia para hacer efectiva la responsabilidad de que trata el artículo 254". Lo mismo decía el art.13-8 del Capítulo I del Reglamento de las Audiencias y Juzgados de octubre de 1812. Pero el Decreto de 17 de julio de 1813 sobre recurso de nulidad iba todavía más lejos: pese a que dicho recurso no cabía contra sentencias firmes, esto no eximía a los jueces y magistrados "de la responsabilidad por falta de 
observancia de las leyes que arreglan el proceso". La regulación detallada de las responsabilidades se hizo por Decreto de 24 de marzo de 1813, que establecía entre los supuestos de responsabilidad el fallo contra ley expresa "por falta de instrucción o por descuido" (art.VII del Capítulo I). Lo mismo sucedía para las Audiencias (art.IX). Los arts.XVI y stes. establecían unas comisiones para revisar causas archivadas que no hubieran sido recurridas a fin de detectar morosidades, resoluciones contra ley expresa o contra la Constitución "o cometido alguna arbitrariedad o abuso que merezca la atención del gobierno".

(365) Pedraz Penalva, Formación, pgs.418 y stes.; pero en cuanto a España sostiene (pg.445) la tesis contraria. Nuestra opinión es exactamente la inversa, como ya hemos expuesto.

(366) Diz-Lois, ob.cit., pg.179, nota 16, y pgs.188 y 211.

(367) Colección de leyes fundamentales, pgs.54 y 55.

(368) En contra se ha manifestado Santamaría Pastor: "En los orígenes del sistema constitucional español, la pugna entre el poder administrativo y el poder judicial fue resuelta netamente a favor de este último. Los legisladores doceañistas diseñaron, de forma enteramente consciente, un poder judicial potenciado independiente y con competencia exclusiva sobre todos los negocios contencioso-administrativos" (ob.cit., pg.79). Pero el modelo judicialista de la Constitución de 1812 no fue más allá precisamente, del otorgamiento de competencia a los tribunales comunes para conocer de lo contencioso-administrativo; en lo demás, el poder judicial estaba completamente supeditado al ejecutivo. Del sistema contencioso-administrativo español no se pueden extraer más consecuencias.

(369) Cfr. Josep Fontana: La quiebra de la monarquía absoluta (1814-1820), Ariel, Barcelona, 2ㄹ. Ed., 1974.

(370) "También está obligado todo español, sin distinción alguna, a contribuir en proporción de sus haberes para los gastos del Estado" (art.8 de la Constitución de 1812).

(371) "La reforma de nuestras instituciones jurídicas ha dependido más de la voluntad del Ministro de Hacienda que del de Justicia, lo mismo hace treinta años, que veinte, que diez, que dos" (Agustín Puebla: Las Audiencias de lo Criminal, Madrid, 1885, pg.16). Así lo prueban disposiciones como el art.223 de la Ordenanza de Montes de 1833: "El juez de letras que, o por ser único en la comarca, o por la designación de que habla el art.173, ha de conocer allí de las causas y negocios contenciosos relativos a estas Ordenanzas que ocurrieren, disfrutará una moderada asignación sobre los fondos de la dirección [se refiere a la Dirección General de Montes, N. del A.] en remuneración de sus ocupaciones de oficio en este ramo; lo mismo se hará con el escribano del juzgado que habitualmente actue en estos negocios".

(372) La obra constitucional de 1812, sostiene Pedraz Penalva, "se plantea desde unos presupuestos ideológicos no concordantes con la realidad que lo debería legitimar; es decir, no parte de la división real de poderes sociales existentes en el país, mientras que a partir de 1837, dicha situación y por lo tanto la Constitución, cambian... La inviabilidad de la Constitución, radicada en su irrealidad, provocó no sólo la no configuración y desarrollo práctico de toda la orgánica institucional del judicial, sino también la supresión y consiguiente restauración de todo el aparato administrativo-judicial del Antiguo Régimen" (Formación, pgs.274 y 406-407).

(373) Entre otros, véase la obra de Francesç Nadal, ya citada; Amparo Rubiales: La región: historia y actualidad, Sevilla, 1973; y Antonio M. Calero Amor: La división provincial de 1833. Bases y antecedentes, Instituto de Estudios de Administración Local, Madrid, 1987.

(374) Al respecto, vid. F. de León y Olarieta: "Reflexiones sobre la ley de orden público", Revista General de Legislación y Jurisprudencia, 1855, tomo VII, pgs.254 y stes.; Pedro Pegenaute: Represión política en el reinado de Fernando VII: Las Comisiones Militares (18241825), Universidad de Navarra, Pamplona, 1974; Manuel Ballbé: Orden público y militarismo en la España constitucional, Alianza, Madrid, 2ª Ed., 1985, pgs.87 y stes.; P.Cruz Villalón: El estado de sitio y la constitución, Centro de Estudios Constitucionales, Madrid, 1980, pg.333.

(375) La democracia... I-2-38, pg.377 
(376) Ob.cit., pgs.149 y 172

(377) "Algunos delitos destruyen inmediatamente la sociedad o quien la representa; otros ofenden la privada seguridad de alguno o algunos ciudadanos en la vida, en los bienes o en el honor; y otros son acciones contrarias a lo que cada uno está obligado a hacer o no hacer, según las leyes, respecto del bien público" (De los delitos y de las penas, Alianza, Madrid, $3^{\text {a }}$ Ed., 1982, pg.39)

(378) El contrato social, II-12, pg.60

(379) Choix, tomo I, pg.378; para Bergasse la organización judicial debía ser desnudada de toda clase de acitividad contra el régimen político del Estado y desprovista de toda influencia sobre las voluntades que concurren a formar ese régimen o a mantenerlo (pg.379). Del mismo modo, Duport, partiendo de la diferenciación entre leyes políticas y civiles, sostenía que el poder ejecutivo se constituye para ejecutar las primeras, y el judicial para las segundas. Las leyes políticas tienen naturaleza constituyente; las civiles no son más que su desarrollo y consecuencia, propias de los poderes constituídos (Choix, tomo III, pgs.228-229)

(380) Ob.cit. pg.66; también Beccaria, Cap.VIII; en parecidos términos E.Gordon ha diferenciado los delitos dirigidos contra los particulares, de los dirigidos contra el Estado, como una forma de introducir lo público y lo privado dentro del Derecho Penal (ob.cit., pgs.240-241).

(381) Colección de leyes fundamentales, pgs.58-59. No pretendemos, al remarcar esta circunstancia, prejuzgar cuál sea la naturaleza de esos "determinados negocios", sino simplemente insistir en que esa distinción entre lo contencioso público y privado existe también entre los constituyentes gaditanos.

(382) Razonaba el marqués de Tabuérniga, al discutir la ley de bases del Consejo de Estado de 1856, que llevar lo contencioso-administrativo al Tribunal Supremo, sería convertirle en el primer poder del Estado, en un poder igual al del trono, cuando en realidad el poder judicial "no es mas que un brazo del Poder ejecutivo". Para el marqués, la independencia conferida a los tribunales no significa autonomía: "Nosotros no queremos que un poder extraño se mezcle jamás en los actos de la Administración, donde los intereses del Estado, por más que se diga, han de tener gran parte. El Estado es siempre el Estado, y aún en aquellos mismos individuos que por creer lastimados sus intereses tienen que agitarse y litigar contra él, tienen también sus intereses en el mismo Estado. Pero la gran cuestión es la de la competencia" (Diario de Sesiones del Congreso, 9 de mayo de 1856, pgs.12116, 13117 y 13118); en parecidos términos diría Carré de Malberg que si la jurisdicción contencioso-administrativa se ejerciera "por los cuerpos judiciales, éstos adquirirían sobre los administradores una superioridad que les permitiría dominarles: por razones políticas, el derecho francés ha querido impedir esta dominación" (ob.cit., tomo I, pg.775).

(383) No obstante, hemos de dejar constancia de la exposición de motivos del proyecto de ley de 13 de julio de 1813 sobre represión de los delitos contra la constitución, no aprobado hasta el 17 de abril de 1821. En aquel texto se pretendía someter los delitos políticos a la jurisdicción ordinaria, ya que los fueros privilegiados no debían extenderse "al quebrantamiento de la ley fundamental del Estado". Pero como decimos, esta ley no se aprobó hasta el trienio y, junto a ella, se aprobó otra de naturaleza procesal que sentaba precisamente el criterio opuesto: la atribución de las causas políticas al conocimiento del fuero de guerra, fuero que en la Constitución estaba expresamente exceptuado de la unidad jurisdiccional y de los "negocios comunes".

(384) M.Ortiz de Zúñiga: Elementos de Derecho Administrativo, Granada, 1843, tomo III, pgs.366-367

(385) Juan Miguel de los Ríos: Derecho Político general, español y europeo, Madrid, 1845, tomo I, pg.107

(386) Mellado, ob.cit., pgs.131 y 306

(387) Teoría de la Constitución, pg.144 
(388) Traité, tomo II, pg.678; de aquí arranca la fundamentación, luego difundida y unánimente aceptada, que presenta a los tres poderes como independientes, separados y constitucioalmente situados a un mismo nivel.

(389) Como ha expuesto Pedraz Penalva, "La jurisdicción...”, pg.928. Según este autor, en el constitucionalismo cada poder representa a un grupo social "y tratamos de deducir a quién representa el poder judicial; Montesquieu nos responde que representa a todos, por consiguiente no representa a nadie; y por lo tanto no es poder" (Formación, pg.351-352).

(390) Choix, tomo III, pg.

(391) Legalidad y legitimidad, Aguilar, Madrid, 1971, pg.53

(392) Filosofía del Derecho, pgs.388 y 389.

(393) Vid. Antonio Esteban Drake: El derecho público subjetivo como instrumentación técnica de las libertades públicas y el problema de la legitimación procesal, Civitas, Madrid, 1981.

(394) Ob.cit., pg.52

(395) Friedrich, Filosofía del Derecho, pg.108

(396) Ensayo, cit., pg.128

(397) Así en su Carta sobre tolerancia dirá también: "No hay juez sobre la tierra entre el magistrado supremo y el pueblo" (pg.54).

(398) "Hay dos clases de contiendas entre los hombres, una resueltas por la ley y otras por la fuerza; éstas son de tal naturaleza que donde una termina la otra siempre empieza" (Carta sobre la tolerancia, pg.54)

(399) Adam Smith, Investigación, pg.629

(400) Ob.cit., pg.61

(401) Cours, tomo I, pg.20.

(402) La democracia..., pgs.158-159

(403) Idem, pgs.354-355

(404) Estudios políticos, pg.98

(405) La defensa..., pg.163

(406) En contra, Pedraz Panalva, "La jurisdicción...", pgs.935 y stes., y Formación, pgs.357 y stes., y especialmente, pgs.397 y stes.

(407) Ob.cit., tomo II, pg.35

(408) Pérez Serrano, con Ruiz del Castillo y Gascón y Marín, La separación de poderes, pg.12

(409) Fouzier-Hermann, ob.cit., pgs.295-296; Duguit, Traité, tomo II, pgs.673-674.

(410) "Inserta en el mismo Estado y reconocida por éste, coexiste con la real una justicia señorial, reconociéndose a los nobles jurisdicción en sus señoríos por el simple hecho de pertenecerle y respecto de la cual el rey no puede nombrar jueces ni intervenir en manera alguna, como no fuese en auxilio que debían prestar al señor cuando éste lo solicitase... Sobrevive el 'ius malectractandi' como jurisdicción de tipo privado ejercida por el señor sobre los siervos, fortaleciéndose incluso ahora con la recepción de los principios romanos y que tienen diversas manifestaciones, llegándose en el siglo XIV en Aragón, con el justicia Martín Díez de Aux, a admitir la facultad de los señores de castigar 'caprichosamente' a sus vasallos, sin mediar justa causa, sin que el rey pueda intervenir en absoluto", derecho que sobrevivió 
hasta 1707 en que se abolió el Derecho público aragonés (Alfonso de Paula Pérez: "Jurisdicción delegada", Enciclopedia Jurídica Seix, tomo XIV, pg.443). Con expresividad característica ponían de relieve las Partidas la obediencia del juez a Dios "e al señor que lo pone". Vid. Calamandrei, ob.cit., tomo I, pg.437, y Pedraz Panalva, Formación, pgs.199 y stes. Para Alemania, Esteban Drake, ob.cit., pg.65. Lo mismo ocurrió en nuestro país, por ejemplo, con el proyecto de ley de ferrocarriles del bienio, atribuyéndose a los capitalistas competencias jurisdiccionales propias de la justicia municipal. Pero incluso en los pueblos, la aristocracia terrateniente asumió personalmente cargos judiciales, como reconocía Dánvila en 1868 ante el Senado: "En Francia -afirmaba el diputado- los Jueces de paz son el primer escalón del orden judicial y están dotados. En España todos los Sres. Diputados saben que son las personas más acomodadas de los pueblos, los cuales ejercen justicia, concilian y responden perfectamente a la idea generadora de su creación" (Diario de Sesiones del Senado, 19 de marzo de 1868, reproducido por la Revista General de Legislación y Jurisprudencia, vol.33, pg.224). Esa "justicia privada" no está, por tanto, tan alejada de nuestra época; bástenos recordar también el reciente debate constituyente en España sobre los tribunales de honor, según algunos autores, como Guaita, permitidos implícitamente por la vigente Constitución en el ámbito militar; y los tribunales de honor son una expresión de justicia privada: vid. Domínguez-Berrueta de Juan: Los tribunales de honor y la Constitución de 1978, Salamanca, 1984.

(411) El Antiguo Régimen, pg.124

(412) "Cuando el Soberano o el jefe ejercían directamente la autoridad judicial, por mucho que abusasen de ella, era casi imposible conseguir desagravio, porque faltaba una instancia lo suficientemente poderosa para pedirle cuentas; pero cuando la ejercía por medio de un bailío, la satisfacción era a veces posible. El Soberano se inclinaba en ocasiones a castigarlo o le obligaba a reparar el daño, si descubría que había cometido algún acto de injusticia, en beneficio propio. Pero si la había cometido en beneficio del príncipe o para adular a quien le había procurado la prebenda, la satisfacción se hacía tan imposible, en tales circunstancias, como si hubiera sido el mismo Soberano quien cometiese la injusticia" (Investigación, pg.634).

(413) El Antiguo Régimen, pgs.178-179

(414) Citado por García de Enterría, Revolución francesa..., pg.48

(415) Ensayo, pgs.115 y 116

(416) La democracia..., I-1-8, pgs.114-115

(417) La defensa..., pg.187

(418) "La figura del juez", en Temas de ordenamiento procesal, Tecnos, Madrid, 1969, tomo I, pg.464.

(419) La situación será diferente en Inglaterra, donde imperará el "common law" tan criticado por Hegel, para quien el Derecho debía ser un sistema y, por tanto, sólo era viable en países cultos, contraponiendo la codificación a la mera recopilación de normas consuetudinarias ( Filosofía del Derecho, pg.284). En España, la "cuestión foral" dará lugar a lo largo de todo el siglo XIX a importantes disputas, de modo que el Código Civil no podrá culminarse hasta fines de siglo y, además, con importantes concesiones a la costumbre como fuente del Derecho.

(420) "Es absolutamente necesario que en la aplicación de las leyes haya conflictos, en los que tiene su lugar el entendimiento del juez, pues de lo contrario la ejecución sería algo totalmente mecánico" (Hegel, Filosofía del Derecho, pg.284)

(421) El Estado moderno, cit. tomo II, pg.364; en España constataba a mediados de siglo Andrés Borrego que "en las causas políticas ha de consultar [el tribunal, N. del A.] otra norma que la de su conciencia, si de antemano no se hallara dispuesto a hacer a ésta el sacrificio de su toga" (Periodismo liberal conservador (1839-1846), Introducción, selección y notas de Concepción de Castro, Catellote, Madrid, 1972, pg.252).

(422) Carré de Malberg, ob.cit., tomo I, pg.792; Lair, ob.cit., pgs.399 y stes. 
(423) Como sostienen García de Enterría y T.R.Fernández, Curso, tomo I, pg.28

(424) "Si examinamos, por ejemplo, lo motivos de los individuos que crean, aplican y obedecen el derecho, encontraremos en su espíritu ciertas ideologías, entre las que desempeña un papel esencial la idea de la justicia" (Kelsen, Teoría general, pg.207).

(425) Tomás y Valiente, "De la administración de justicia...", en El poder judicial en el Bicentenario, pgs.13-14

(426) Ob.cit., pg.76

(427) Précis, pg.367.

(428) Principios de Ciencia Política, Tecnos, Madrid, 1969, vol.2, pg.32.

(429) Carl Schmitt, Estudios políticos, pgs.23-24, 141-142, 151-152 y 156.

(430) Ob.cit., pg.162

(431) Investigación, pg.633

(432) Filosofía del Derecho, pgs.280-281

(433) Teoría de la constitución, pg.141

(434) Ralph Miliband: El Estado en la sociedad capitalista, Siglo XXI, Madrid, 13를. Ed., 1985, pg.53

(435) Por reducción al absurdo, razonaba Duguit que si el Estado fuera soberano, lo sería siempre y actuaría siempre como tal; que, en consecuencia, las relaciones jurídicas del Estado con los demás deberían ser siempre desiguales, de superior a subordinado; pero como existen también las relaciones de igualdad, se deduce de aquí que, o bien el Estado no es soberano, o bien hay una esquizofrenia en la naturaleza del Estado, dividido entre un Estado-soberano y un Estado-fisco, lo que atenta al principio de unidad del Estado (Traité, tomo I, pg.78). A nuestro entender, la quiebra no se produce en la naturaleza soberana del Estado, ni en su unidad, sino precisamente en que no existen esas relaciones igualitarias a las que se refería Duguit.

(436) Ob.cit., tomo I, pg.748

(437) "La función jurisdiccional y el 'status' de jueces y magistrados”, en Justicia 86, núm. 1, pg.11; también en "La unidad jurisdiccional...", pg.437

(438) Traité, tomo I, pgs.710-711

(439) Ob.cit., pg.325

(440) Maurice Hauriou, Précis, pgs.28 y stes.

(441) Teoría general, pg.250.

(442) Ensayos, Aguilar, Buenos Aires, 4를. Ed., 1980, pg.212. Bacon especificó con gran claridad a qué se refería: "Llamo materia de Estado no sólo a los elementos de soberanía sino todo lo que introduzca una gran alteración o precedentes peligrosos o concierna manifiestamente a gran parte del pueblo" (pg.216). Rechazó que hubiera oposición entre las "leyes justas" y la "verdadera política estatal" que deben moverse al unísono. Y es más conocida su conclusión: los jueces pueden ser leones, pero leones bajo el trono: "No deben oponerse a la soberanía" (pg.217).

(443) Teoría general, pg.244

(444) Derecho Constitucional e instituciones políticas, Ariel, Barcelona, 11를., 1973, pg.220; J.González Pérez: Administración Pública y libertad, México, 1971, pgs.68 y stes.; Carl Schmitt, Teoría de la constitución, pg.143 
(445) "En el mundo actual es mucho más rica en matices y consecuencias la visión del Estado actuando jurisdiccionalmente que la del proceso, en que el Estado es simplemente uno de sus sujetos" (J. Montero Aroca: "La unidad jurisdiccional: su consideración como garantía de la independencia judicial", en Libro-homenaje a Jaime Guasp, Comares, Granada, 1984, pgs.427428).

(446) Vid. J.M.Olarieta Alberdi: "Injerencias político-administrativas en el proceso penal. Sistema histórico y evolución legislativa", en Revista Vasca de Administración Pública, núm.22, setiembre-diciembre de 1988

(447) El Decreto constitutivo de este Tribunal se encuentra en el Archivo Histórico Nacional, Sección Estado, Junta Central Suprema, Legajo 29; si bien no llegó a ponerse en funcionamiento, fue sustituído por el Tribunal Extraordinario de Seguridad Pública, muy similar a aquel. Vid. Manuel Ballbé: Orden público, pgs.45 a 49; A.Fiestas Loza: Los delitos políticos 1808-1939, Salamanca, 1977, pg.52; y Blanco Valdés, ob.cit., pgs.298 a 300.

(448) Estudios..., pgs.408-409

(449) Cours, tomo I, pgs.35 y stes.

(450) Ibid, tomo I, pg.38

(451) Introducción para la historia de la revolución de España, Londres, 1810, pg.220.

(452) Villar Palasí, ob.cit., pg.136.

(453) Legalidad y legitimidad, pgs.127-128.

(454) L'esprit du Droit Romain, Paris, 1873, tomo IV, pgs.325 y stes.

(455) La paternidad del concepto de derecho público subjetivo se imputa a Jellinek, quien los fundamentaba en la personalidad y los calificaba de estatuto: no recaen sobre cosas, sino que describen "la relación permanente que existe entre el individuo y el Estado" (Teoría general, pg.313). Del mismo modo, para Kelsen, los derechos públicos subjetivos no son "de por si" derechos subjetivos (Teoría pura del Derecho, pgs.150 y stes). Vid también Esteban Drake, ob.cit.

(456) Carl Schmitt, Legalidad y legitimidad, pg.86

(457) Teoría general, pgs.591-595

(458) La declaración de derechos -afirmó Mirabeau- no podía adoptar la forma de ley (Choix, tomo I, pg.230)

(459) Choix, tomo I, pg.214. Nos parece importante retener las palabras de Malouet: "Tenemos por conciudadanos a una multitud inmensa de hombres sin propiedades, que esperan, antes que todo, su subsistencia de un trabajo asegurado, de una policía exacta, de una protección continua, que se irritan alguna vez, no sin justos motivos, del espectáculo del lujo y de la opulencia". No deduce de aquí Malouet que la multitud carezca de libertad; por contra la libertad, lo mismo que la luz del día, debe iluminar a todos; lo que preconiza es que quienes están situados en ua situación dependiente vean más los límites que la extensión de la libertad natural (pg.215). La igualdad original, para Landine, no era más que una ficción filosófica: tengamos cuidado -advertía- porque hemos roto un dique conservado durante siglos; debemos ponernos al abrigo de un torrente cuyas olas pueden ir más lejos de lo previsto (pg.221).

(460) Lucas Verdú, Curso, vol.2, pg.658. "Si puede haber algún equilibrio entre los que lo tienen todo y los que no tienen nada, es solamente entre la necesidad que tiene el pobre del dinero del rico, y el que tiene el rico de la industria del pobre, donde este equilibrio se puede establecer" (Condorcet: "Reflexiones sobre el comercio del trigo", en Oeuvres, tomo XI, pgs.104-105)

(461) Pedraz Penalva, Formación, pgs.212 y stes. 
(462) La concepción del nuevo Estado burgués es radicalmente inversa a la del viejo Imperio, "un eficaz abogado de los oprimidos" (Hattenhauer, ob.cit., pg.33).

(463) J.R.Capella: Materiales para la crítica de la filosofía del Estado, Fontanella, Barcelona, 1976, pg.14; Pedraz Penalva, Formación, pg.98.

(464) "Quien dependa de otro y no obtenga sus recursos de sí mismo, no sabría ser libre", afirmaba Rousseau (Projet pour la Corse, pg.106). Vid también Sieyes, ¿Qué es el tercer estado?, pg.32. Para Kant "sólo la capacidad de votar cualifica al ciudadano", lo que a su vez exige una independencia que no concurre en los mozos, mujeres, sirvientes y, en general, en "cualquiera que no puede conservar su existencia (su sustento y protección) por su propia actividad, sino que se ve forzado a ponerse a las órdenes de otros (salvo a las del Estado) carece de personalidad civil... son únicamente peones de la comunidad, porque tienen que ser mandados o protegidos por otros individuos, por tanto, no poseen independencia civil" (Metafísica de las costumbres, pg.144).

(465) ¿Qué es el tercer estado?, pg.113

(466) Cours, tomo I, pg.136.

(467) Ibid. tomo I, pgs.144 y stes.

(468) Colección de leyes fundamentales, pg.39

(469) Ibid, pg.42

(470) lbid, pg.49

(471) "La clase media de un lado, queriendo conservar sus ventajas, y los padeceres de las masas de otro, estimulándolas a conmover las sociedades, han fijado, por fin, la atención de nuestro siglo y hecho conocer la falacia de los principios de libertad proclamados por el viejo liberalismo. La libertad de sus ideas no era la libertad de los hombres, sino su libertad propia para después perpetuar, bajo diferentes maneras, las mismas explotaciones contra las que tanto se clamara. El choque continuo, producido por estas circunstancias, constituye las sociedades en un estado tan vacilante e incierto que es imposible se desarrollen con armonía los elementos de progreso que nuestra época encierra en su seno" (Periodismo..., pg.80)

(472) Ob.cit., tomo I, pg.28

(473) Ob.cit., pgs.80-83

(474) La democracia..., pg.376

(475) La democracia..., I-1-2, pg.56

(476) "Política de un problema...", cit., pg.23

(477) En alusión a Inglaterra, vid García de Enterría y T.R.Fernández, Curso, tomo I, pg.463.

(478) La democracia..., I-2-38, pgs.377-378

(479) ¿Qué es el tercer estado?, pg.28; Soboul, La revolución francesa, pg.13.

(480) Ensayo sobre los privilegios, pg.49; para Carl Schmitt "el último guardián de todo derecho, el último garante del orden establecido, la última fuente de toda legalidad, la última seguridad y la última protección frente a la injusticia es el legislador y el procedimiento empleado por él para legislar. El abuso del poder legislativo y del procedimiento legislativo tiene que quedar prácticamente descartado, pues de no ser así se haría inmediatamente preciso un Estado diferente, con una estructura y una organización completamente distintas. La congruencia y la armonía preestablecidas y presumidas entre Derecho y ley, justicia y legalidad, objeto del Derecho y procedimiento legislativo dominan hasta el último detalle la idea del Derecho propia del Estado legislativo. Sólo así ha sido posible someterse al imperio de la ley precisamente en nombre de la libertad, borrar de la tabla de derechos de la libertad el 
derecho de resistencia y conceder a la ley aquella preeminencia incondicionada que veía en el sometimiento del juez a la ley una garantía de la independencia judicial, que consideraba que el subordinar la Administración a la ley significaba la protección más importante frente al abuso del poder estatal y que ponía sin reparo todos los derechos garantizados por la Constitución a merced del legislador, quien podía atentar contra ellos a su arbitrio en virtud del monopolio de la ley" (Legalidad y legitimidad, pgs.28-29; y La defensa..., pgs.97-98). Sin embargo, no resulta cierta la libre disponibilidad de los derechos y libertades por la Asamblea legislativa, sino que, por el contrario, constituían "obligaciones"que debía respetar; el problema radicaba en que no había forma de hacer exigible esa "obligación" del legislador por la vía jurídica; otra cosa es el derecho de resistencia, verdadera clausula de cierre del sistema de "derechos".

(481) Cfr. M.Lorente Sariñena: Las infracciones a la Constitución de 1812, Centro de Estudios Constitucionales, Madrid, 1988

(482) Y añadía: "Decir que el bien particular debe ceder ante el bien público es un paralogismo: esto no ocurre más que en los casos en que se trata del imperio de la ciudad, es decir, de la libertad del ciudadano; pero no ocurre en aquellos en que se trata de la propiedad de los bienes, porque el bien público consiste siempre en que cada cual conserve invariablemente la propiedad que le dan las leyes civiles" (ob.cit., XXVI-15, pg.377)

(483) Del contrato social, II-12

(484) "La unidad jurisdiccional..., pgs.432-433; pero no se trata, com afirma Montero Aroca, de la igualdad, sino de la igualdad ante la ley, de la aplicación uniforme del Derecho positivo.

(485) Colección de leyes fundamentales, pg.50

(486) F.Tomás y Valiente: El Derecho Penal de la monarquía absoluta, Tecnos, Madrid, 1969, pg.167. "No perdamos de vista -añade Tomás y Valiente- que en el proceso inquisitivo el juez tiene por lo menos tanto de policía como de oficial administrador de justicia" (pg.168). Vid. Pedraz Panalva, Formación, pgs.149 y stes.

(487) Idem, pg.157; véase también, Agustín Puebla, ob.cit., pgs.19 y 24

(488) Ob.cit., tomo I, pg.25

(489) Ibid, tomo I, pg.48

(490) Colección de leyes fundamentales, pgs.42-43

(491) Choix, tomo I, pg.252

(492) "Las leyes son las condiciones con que los hombres aislados e independientes se unieron en sociedad, cansados de vivir en un continuo estado de guerra, y de gozar de una libertad que les era inútil en la incertidumbre de conservarla. Sacrificaron por eso una parte de ella para gozar la restante en segura tranquilidad. La suma de todas estas porciones de libertad, sacrificadas al bien de cada uno, forma la soberanía de la nación, y el soberano es su administrador y legítimo depositario" (Beccaria, De los delitos..., Cap.I)

(493) ¿Qué es el tercer estado?, pg.77

(494) En defensa..., pg.64

(495) Sieyes, ¿Qué es el tercer estado?, pg.112

(496) Traité, tomo II, pg.176

(497) Chastenet, ob.cit., pgs.32-33

(498) Strethearn Gordon: El parlamento británico, Londres, 1948, pg.23.

(499) La democracia..., I-1-9, pg.122 
(500) ¿Qué es el tercer estado?, pg.53

(501) Curso, vol.2, pg.660; en igual sentido, C.Schmitt: Sobre el parlamentarismo, Tecnos, Madrid, 1990, pgs.43 a 47.

(502) Por contra R.Calzada Conde sostiene que no se reconoció en Francia y España el derecho de reunión para evitar que la aristocracia se aprovechara de ellos, que fue un silencio "progresista" ("El principio configurador y garantista en la Constitución de Cádiz", en Materiales para el estudio de la Constitución de 1812, pg.153). Pensamos que la aristocracia hizo uso de las reuniones, existiera o no el derecho, e incluso pese a estar prohibido, pero que el verdadero objeto del silencio y la prohibición de las reuniones eran los motines del pueblo.

(503) Diario de Sesiones del Congreso, 15 de octubre de 1820

(504) Diario de Sesiones, 4 de setiembre de 1820

(505) Pedraz Penalva, Formación, pgs.48 y stes.; y Emilio La Parra López: La libertad de prensa en las Cortes de Cádiz, Valencia, 1984, pg.69.

(506) "Entre los príncipes y la Iglesia se había establecido una especie de intercambio; ellos les prestaban su fuerza material y ella les prestaba su autoridad moral; ellos hacían obedecer los preceptos de la Iglesia, y ésta hacía respetar la voluntad de los príncipes" (Tocqueville: El Antiguo Régimen, pg.201)

(507) El Antiguo Régimen, pgs.37 y 39

(508) "Es una verdad incuestionable en los países regidos por gobiernos representativos, que la prensa periódica es el principal baluarte que defiende la libertad contra las irrupciones del poder arbitrado, disfrazado de mil maneras para hollar los derechos imprescriptibles del pueblo. Ocupados los ciudadanos en las afanosas tareas que son indispensables para adquirirse los medios de satisfacer las necesidades de la vida civil, no pueden tener clavados los ojos en los agentes de la administración para denuciar sus procedimientos tan luego como salten los límites que la ley les tiene de antemano prefijados. Pero la imprenta, consagrada de continuo a velar por la conservación de las instituciones liberales, se ve forzada a examinar los actos del gobierno, a ejercer sobre ellos una severa censura, para tener al pueblo al corriente de todos los pormenores de la administración del Estado, a fin de que la fuerza incomensurable a la opinión ejerza una influencia provechosa en la conciencia de los gobernantes" (Andrés Borrego, "Periodismo...", pgs.127-128).

(509) Cours, tomo I, pg.155.

(510) La democracia..., I-2-38, pg.376.

(511) M.Moreno Alonso: "Las ideas constitucionales de Blanco White", en Materiales..., pg.537.

(512) Los delitos políticos, pg.48; y M. Cruz Seoane: Historia del periodismo en España 2. El siglo XIX, Alianza, Madrid, 1983, pgs.36 y stes.

(513) Gil Novales, ob.cit., tomo I, pg.554

(514) La Parra, ob.cit., pg.58

(515) El art.142 del Código Penal de 1822 estipulaba: "El que impidiere o coartare a algún español el ejercicio de la facultad legítima que tiene para hablar, escribir u hacer libremente todo aquello que no esté prohibido o se prohibiere por las leyes o por legítima autoridad con arreglo a ellas, y que no ceda en perjuicio de otra persona, o que aunque ceda esté autorizado por la ley, es violador de la libertad de imprenta y sufrirá un arresto de dos días a dos meses".

(516) Condorcet: "Fragments sur la liberté de la presse", Oeuvres, tomo XI, pgs.253 y stes.

(517) Los arts.592 a 604 del Código Penal de 1822 enumeraban las distintas modalidades de "abuso" de la libertad de imprenta, a los que añadía la introducción de libros en castellano impresos fuera del país y la colocación de pasquines. 
(518) La Constitución española de 1812 (El constitucionalismo liberal a principios del siglo XIX), Valencia, 1978, pg.131.

(519) Ob.cit., pg.58.

(520) Idem, pg.67

(521) Fouzier-Herman calificó a los primeros constituyentes franceses de "fanáticos de las elecciones" (ob.cit, pg.290), de una época de "fiebre electoral" que hacía del sufragio "la fuente inmediata de todas las funciones" (pg.207); vid. P.Gaxotte: La revolución francesa, Doncel, Madrid, 1975, pg.175; y J.Otero de Navascués: Táctica de las revoluciones. La Gironda: el asalto al poder, Madrid, 1951, pg.55.

(522) Gaxotte, ob.cit., pgs.193-194 y 202, luego "el reemplazo de los ministros fuldenses por ministros girondinos en el mes de marzo de 1792 abre -afirma Troper- una nueva era: los ministros deben, en lo sucesivo, para permanecer en el poder, disfrutar de la confianza de los dos órganos legislativos" (ob.cit., pg.168).

(523) El terror puede caracterizarse precisamente por el empleo de tribunales extraordinarios y de procedimientos expeditivos: por la concentración de poderes, en definitiva. Lo cual no significa la negación de la libertad que la revolución francesa perseguía, sino el camino hacia ella: "Ninguna obra ni acto positivos -decía Hegel en referencia al terror- puede producir la libertad universal; a dicha libertad sólo le resta el obrar negativo; es solamente la furia del desaparecer" (Fenomenología del espíritu, Fondo de Cultura Económica, México, 1966, pg.346).

(524) Vid. Soboul, Principios ideológicos..., pgs.326 y stes.

(525) Kühnl, ob.cit., pg.44

(526) Troper, ob.cit., pgs.207-208; este autor salta desde las teorías imperantes bajo la monarquía de julio (Beniat Saint-Prix) hasta la III República, cuando la Academia acepta en 1880 el criterio de Saint-Girons; no menciona para nada a los doctrinarios, que jugaron en erste punto un papel decisivo (Jellinek, Teoría general, pgs.376-377) precisamente al concebir un "cuarto poder" con el carácter -además- de "moderador" y situado por encima de los otros tres, cuando no era sino un poder más: entonces el ejecutivo se equipara -más bien se impone- al parlamento. Teniendo en cuenta el carácter no electivo de la corona, la operación ideológica resalta con particular énfasis.

(527) Alejandro Nieto, La burocracia, pgs.54 y stes.

(528) "Los revolucionarios, en el momento de plasmar el Estado nuevo, siguen una interpretación claramente disidente de la ortodoxia doctrinal que representaban; esta interpretación, junto con las circunstancias históricas de la Revolución y de los tiempos posteriores, permitieron y determinaron el fortalecimiento de una Administración como no había conocido siquiera el antiguo régimen" (García de Enterría, Revolución francesa, pg.33; Villar Palasí, ob.cit., pgs.197 y stes.).

(529) Marc Bouloiseau: La República jacobina, Ariel, Barcelona, 1980, pgs.177 y stes.

(530) Villar Palasí, ob.cit., pg.198

(531) Cfr. Adolfo Posada: Teorías políticas, Madrid, 1905, pgs.39 y stes.

(532) Un análisis del proceso en Carré de Malberg, ob.cit., tomo I, pgs.777 y stes.; también Duguit, Traité, tomo II, pgs.678 y stes.

(533) No significa esto que la revolución burguesa en Francia siguiera también una "vía prusiana" o no revolucionaria, característica de otros países europeos; en Francia la revolución ya se había iniciado, y esta toma de las riendas de la Administración es un paso en su proceso de radicalización y profundización que la aleja de los demás Estados europeos. Al respecto, cfr. las atinadas observaciones de Soboul, Principios ideológicos..., pgs.54 a 58. 
(534) El Antiguo Régimen, pg.33; también en pg.212 imputa esta misma idea a los fisiócratas.

(535) Santamaría Pastor, ob.cit., pg.111

(536) Las teorías ideadas para justificar la facultad sancionadora de la Administración eran sugestivas: "Si la Administración ejerce alguna vez el derecho de imponer penas pecuniarias o corporales, débese a una delegación especial del poder legislativo que para robustecer la acción del poder administrativo, le confiere facultades coercitivas y le reviste de una jurisdicción excepcional y limitada por tanto a los casos expresamente señaldos en la ley" (M.Colmeiro: Derecho Administrativo español, Madrid, 1850, tomo I, pg.41).

(537) Cfr. J.R.Parada Vázquez: "La responsabilidad criminal de los funcionarios públicos y sus obstáculos", Revista de Administración Pública, 1960, núm. 31; y también Olarieta Alberdi, "La autorización administrativa previa para procesar a los funcionarios públicos", en Revista de Estudios Administración Local y Autonómica, ya citado.

(538) Cours, tomo I, pg.14

(539) No faltan autores, como Agúndez (ob.cit., pg.102), que se refieren al primer constitucionalismo, calificando al rey de "jefe del Estado". Esto es completamente ajeno a aquella época, ya que las primeras menciones a tal órgano surgen con las Cartas francesas de 1814 (art.14) y 1830 (art.13), así como en la Constitución belga del mismo año (art.62). Hasta ese momento, si pudiera hablarse de un "jefe del Estado", habría que referirse a la asamblea legislativa.

(540) Teoría general, pgs.418 y stes. 